UNIVERSIDADE DE SÃO PAULO

FACULDADE DE FILOSOFIA, LETRAS E CIÊNCIAS HUMANAS DEPARTAMENTO DE FILOSOFIA

PROGRAMA DE PÓS-GRADUAÇÃO EM FILOSOFIA

\title{
O JOVEM HEGEL LEITOR DE KANT: CRÍTICA, REFLEXÃO E ESPECULAÇÃO
}

DANIEL REHFELD

São Paulo

2012 
UNIVERSIDADE DE SÃO PAULO

FACULDADE DE FILOSOFIA, LETRAS E CIÊNCIAS HUMANAS

DEPARTAMENTO DE FILOSOFIA

PROGRAMA DE PÓS-GRADUAÇÃO EM FILOSOFIA

\title{
O JOVEM HEGEL LEITOR DE KANT: CRÍTICA, REFLEXÃO E ESPECULAÇÃO.
}

\author{
DANIEL REHFELD
}

Dissertação apresentada ao Programa de Pós-graduação em Filosofia da Faculdade de Filosofia, Letras e Ciências Humanas da Universidade de São Paulo, como requisito para obtenção do título de Mestre.

Orientador: Prof. Dr. Marco Aurélio Werle

SÃO PAULO

2012 
Banca Examinadora:

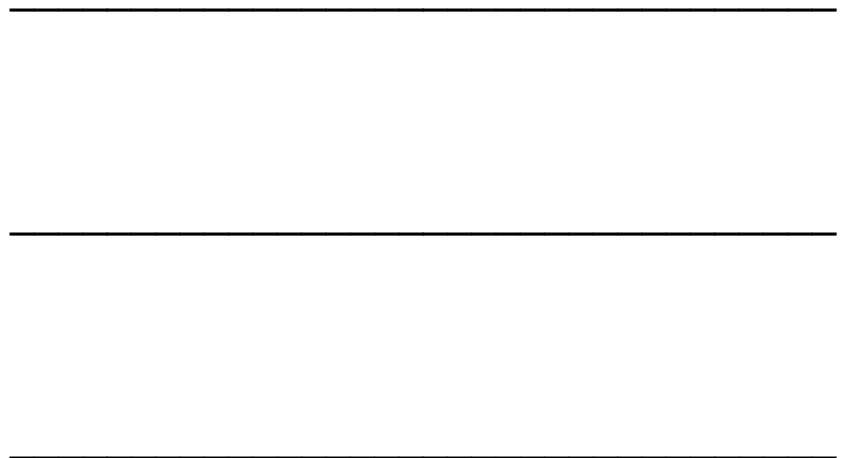


Aos meus avós Walter, Coca, e Vavá, de quem sinto muita falta. 


\section{Agradecimentos:}

Agradeço ao CNPq, cujo financiamento permitiu a realização desta pesquisa.

Meus sinceros agradecimentos ao professor e orientador desta dissertação, Marco Aurélio Werle, pela atenção, disponibilidade e exemplo de dedicação.

Agradeço também aos professores Márcio Suzuki e Ricardo Terra, que aceitaram participar da banca de qualificação, e cujas orientações foram decisivas para o percurso deste trabalho.

Aos meus pais, Ari e Ju, pela proximidade e pela confiança com que me criaram. Sou infinitamente grato pela riqueza do tempo que passamos juntos.

À minha avó Loli, com quem tenho o privilégio de conviver. Por estar sempre próxima, com seu carinho e seu saber. Meus estudos de filosofia alemã devem muito a você.

Ao Bruno Rates, um exemplo de que saber e amizade caminham juntos. Este trabalho é apenas mais um fruto de nossas infinitas conversas.

Ao Arturo Gamero, amigo-poeta, que sempre me relembra do valor das palavras.

Ao Leonardo Niro, que mesmo à distâcia se manteve presente na realização deste trabalho.

Ao amigo Ulisses Vacarri, pelos cafés e pelas longas conversas.

Ao amigo Bruno Santos, companheiro na jornada da filosofia.

Ao Leonardo T. B. Yoshimochi, amizade imprescindível e companheiro de sempre.

Ao amigo Caio Milnitzky, pela amizade única.

E, por fim, à Alice, companheira na vida, e que a cada sorriso transforma meu mundo. Agradeço seu apoio e compreensão ao longo desse trabalho que nos acompanha desde o começo. 


\section{RESUMO}

REHFELD, D. O jovem Hegel leitor de Kant: Crítica, Reflexão e Especulação. 2012. 207f. Dissertação (Mestrado) - Faculdade de Filosofia, Letras e Ciências Humanas. Departamento de Filosofia, Universidade de São Paulo.

Este trabalho tem como objetivo abordar a leitura que o jovem Hegel faz da filosofia kantiana, tendo como foco o desenvolvimento da noção de especulação a partir da relação estabelecida com a reflexão, característica fundamental daquela filosofia. Através do reconhecimento da presença de "idéias especulativas" nessa filosofia, Hegel orienta sua interpretação pela crítica ao caráter formal das "filosofias da reflexão" e ao "princípio da subjetividade” no qual elas se enraízam. Sua leitura é conduzida pela tentativa de restituir a "idéia da razão", como unidade primordial e absoluta do sujeito e objeto, que na filosofia crítica somente pôde ser vislumbrada enquanto tarefa, mas cuja realização se encontra ali de antemão impedida. Pretende-se, ao longo do trabalho, acompanhar como Hegel chega a constatar a ambigüidade inscrita na reflexão filosófica kantiana e de que maneira ele a submete a uma reinterpretação especulativa que destaca, de sua interpretação finita (crítica), uma "reflexão especulativa" como instrumento positivo do conhecer absoluto. Através do reconhecimento destas duas formas distintas de interpretar o sentido da reflexão e de sua atividade, voltamo-nos ao modo com que Hegel desenvolve a distinção kantiana entre Razão e Entendimento, porém agora não mais compreendidas enquanto faculdades do espírito, mas como modos distintos de interpretação do real.

PALAVRAS-CHAVE: Reflexão; Crítica; Especulação; Razão; História da filosofia. 


\begin{abstract}
REHFELD, D. The joung Hegel reader of Kant: Critique, Reflection and Speculation. 2012. 207f. Thesis (Master Deegre) - Faculdade de Filosofia, Letras e Ciências Humanas. Departamento de Filosofia, Universidade de São Paulo, 2012.

The aim of this work is to approach the reading by the young Hegel of the Kantian philosophy, with the focus on the development of the notion of speculation out of the relationship established with the reflection, which fundamentally characterizes that philosophy. Through the recognition of the presence of "speculative ideas" in this philosophy, Hegel guides his interpretation by a critique to the formal character of the "reflection philosophies" and to the "principle of subjectivity" upon which they stand. His reading is guided by an attempt to reestablish the "idea of reason" as the foremost and absolute unity of the subject and object, which in the critical philosophy can only be envisaged as a task, which can not then be accomplished. The intention along this work is to follow how Hegel arrives at the finding of the ambiguity embedded in Kant's philosophical reflection and how he submits it to a speculative reinterpretation, which distinguishes from within its finite interpretation (critical) a speculative reflection as a positive instrument of the absolute knowledge. Through recognizing these two distinct forms of interpreting the sense of the reflection and of its activity, we turn back to the manner which Hegel develops the Kantian distinction between Reason and Understanding, no longer seen as faculties of the spirit, but as two distinct ways of interpreting reality.
\end{abstract}

Key-Words: Reflection, Speculation, Critique, Reason, History of Philosophy. 


\section{SUMÁRIO}

NOTAS SOBRE AS CITAÇÕES E ABREVIATURAS

INTRODUÇÃO 4

CAPÍTULO I: HEGEL LEITOR DE KANT: "A ARTE DE LER HEGELIANA" 16

1. Os dois espíritos da filosofia de Kant. 22

2. O filosofar e os sistemas filosóficos.

CAPÍTULO II: FILOSOFIAS DA REFLEX̃̃O

1. A razão tratada com entendimento 47

2. Reflexão e Crítica: A filosofia de Kant 62

2.1 Reflexão: instância fundamental da crítica $\quad 64$

2.2 Para além da reflexão crítica $\quad 86$

CAPÍTULO III: REFLEXÃO E VIDA 107

1. A unidade concreta da vida e a unidade abstrata do conceito 110

2. A reabilitação parcial da filosofia. $\quad 129$

CAPÍTULO IV: ESPECULAÇÃO E A AMBIGÜIDADE DO PENSAR 143

1. A reinterpretação especulativa da reflexão 146

1.1 Reflexão como instrumento do filosofar: a construção do absoluto para a consciência. $\quad 156$

2. Reflexão e a semente do especulativo 176

CONSIDERAÇÕES FINAIS $\quad 189$

REFERÊNCIAS BIBLIOGRÁFICAS 


\section{NOTAS SOBRE AS CITAÇÕES E ABREVIATURAS}

\section{HEGEL}

As obras de Hegel são citadas de acordo com a edição da Suhrkamp (G.W.F. Hegel, Werke in 20 Bänden (1986), E. Moldenhauer \& K.M. Michel [eds.], Frankfurt am Main) e indicadas através da sigla HW seguido do volume, em algarismo arábico, e da respectiva página. Obras que recebem uma maior atenção em nosso trabalho são indicadas com a abreviatura abaixo apresentada.

GCh Der Geist des Christentums und sein Schicksal (1798-1800)

SF Systemfragment von 1800. (1800)

DS Differenz des Fichteschen und Schellingschen Systems der Philosophie in Beziehung auf Reinhold's Beyträge zur leichtern übersicht der Philosophie zu Anfang des neunzehnten Jahrhunderts. (1801)

ÜWPhK Über das Wesen der philosophischen Kritik überhaupt und ihr Verhältnis zum gegenwärtigen Zustand der Philosophie insbesondere. (1802)

VSPh Verhältnis des Skeptizismus zur Philosophie. Darstellung seiner verschiedenen Modifikationen und Vergleichung des neuesten mit dem alten. (1802)

GuW Glauben und Wissen oder die Reflexionsphilosophie der Subjektivität in der Vollständigkeit ihrer Formen als Kantische, Jacobische und Fichtesche Philosophie. (1802)

PhG Phänomenologie des Geistes (1807)

WdL Wissenschaft der Logik. ([1812]-1832) 


\section{KANT}

As obras de Kant serão citadas de acordo com a edição da Academia (Kants gesammelte Schriften: herausgegeben von der Deutschen Akademie der Wissenschaften, anteriormente Königlichen Preussischen Akademie der Wissenschaften, 29 vols. Berlin, Walter de Gruyter, 1902, na seguinte ordem: abreviatura da obra, número do tomo em algarismo romano e número da página em algarismo arábico. A Crítica da Razão Pura será citada segundo as edições A (1781) e B (1789).

$\begin{array}{ll}\text { KrV } & \text { Kritik der reinen Vernunft (A 1781, B 1789) } \\ \text { WA } & \text { Beantwortung der Frage: Was ist Aufklärung? (1784) } \\ \text { GMS } & \text { Grundlegung zur Metaphysik der Sitten (1785) } \\ \text { KpV } & \text { Kritik der praktischen Vernunft (1788) } \\ \text { KU } & \text { Kritik der Urteilskraft (1790) } \\ \text { Anth } & \text { Anthropologie in pragmatischer Hinsicht (1798) } \\ \text { EEKU } & \text { Erste Einleitung in die Kritik der Urteilskraft } \\ \text { Log } & \text { Logik (Jäsche) } \\ \text { V-Lo/Blomberg } & \text { Logik Blomberg } \\ \text { V-Lo/Wiener } & \text { Wiener Logik }\end{array}$




$\begin{array}{ll}\text { V-Lo/Pölitz } & \text { Logik Pölitz } \\ \text { V-Lo/Philippi } & \text { Logik Philippi } \\ \text { V-Lo/Dohna } & \text { Logik Dohna-Wundlacken } \\ \text { Rx } & \text { Reflexionen }\end{array}$

No que se refere às traduções para o português, elas são de minha autoria e utilizam, quando indicado, das demais traduções, referenciadas na bibliografia. As citações da Crítica da Razão Pura se utilizam da tradução portuguesa de Manuela P. dos Santos \& Alexandre F. Morujão, editadas pela Fundação Calouste Gulbenkian, Lisboa, 1997. 


\section{INTRODUÇÃO}

"Hegel crítico de Kant”, "De Kant a Hegel”, “Entre Kant e Hegel”, “A recepção hegeliana da filosofia de Kant" - estes são alguns dos títulos de muitos livros e ensaios que se debruçam sobre a relação entre duas filosofias, cujo diálogo revela ao mesmo tempo proximidade e distância. Compreendendo um período de efervescência da filosofia alemã, estas obras pretendem determinar os mais variados aspectos, históricos e do pensamento, que participam da tensa passagem de uma filosofia à outra. $\mathrm{O}$ presente trabalho pretende também se inserir nesta vasta bibliografia, porém possui uma investigação bastante circunscrita: suas análises voltam-se à leitura que Hegel faz da filosofia kantiana à época da constituição de suas primeiras elaborações propriamente filosóficas, que ocorrem na transição dos últimos anos que Hegel trabalha em Frankfurt ao período inicial de sua estadia em Jena. Sua intenção maior é a de tematizar como a filosofia especulativa hegeliana pôde surgir a partir de uma leitura muito específica da ambigüidade inscrita na reflexão filosófica kantiana. Nesse sentido, o horizonte geral que orienta todo o desenvolvimento do trabalho é a busca da explicitação da própria perspectiva que conduz a leitura hegeliana e em que medida ela permite extrair a especulação de um sistema que, segundo Hegel, insiste em recusá-lo em seu interior. "Hegel leitor de Kant" é, portanto, o título de um trabalho que não tem como objetivo avaliar a retidão ou as "injustiças" da avaliação crítica que Hegel faz de Kant, mas que pretende fundamentalmente abordar como Hegel desenvolve os primeiros contornos de sua concepção de especulação a partir do confronto com o modo de pensar kantiano.

Desde seus primeiros textos, ainda de cunho principalmente teológico, a filosofia de Kant já aparecia a Hegel sob a luz de uma apreciação ambivalente. Por um lado mostrava-se como a filosofia que restitui à razão sua autonomia e sua condição de autolegisladora, retirando-a das amarras de uma religião positiva fundada na legalidade formal, recuperando assim o interesse racional da religião a partir de sua "necessidade racional prática" (HW I, p. 79). Por outro lado, em sentido inverso, a filosofia teórica kantiana parecia rebaixar a razão aos limites de um entendimento formal - e que em sentido estrito não se distinguia do são entendimento comum (gesunder 
Menschenverstand) -, e que por seu turno tinha sua circunscrição determinada pela sensibilidade doadora de sentido e significado para as suas categorias que, de outro modo, permaneciam vazias. Sua filosofia prática, por sua vez, repetia também essa renúncia a esse suposto poder recém-conquistado na medida em que seu imperativo categórico, em sua exclusão de toda relação à sensibilidade enquanto móbil da ação moral, permanecia ainda representado através de uma lei que se contrapunha às inclinações sensíveis da vontade, exercendo assim uma nova forma de dominação, agora interiorizada no sujeito (HW I, p. 301).

Essa ambivalência contida no juízo hegeliano era, todavia, o reconhecimento de uma tensão no núcleo dessa filosofia que trazia à luz, de maneira mais nítida, um movimento histórico e cultural próprio à época moderna, intensificado em seus conflitos na maneira de pensar própria ao Iluminismo e ao Protestantismo ${ }^{1}$. Como diagnóstico de época, a categoria "filosofias da reflexão", denominação criada por Hegel na época de Jena, surgira com o intuito de apresentar os impasses de diversas filosofias subordinadas ao espírito kantiano e que traduziam em um pensar filosófico as oposições fundamentais referentes àquilo que há de mais "valioso" e "sagrado" para o homem - de uma época caracterizada pelo "dilaceramento" (Zerrissenheit) e pela "cisão" (Entzweiung) absoluta, isto é, uma época em que, como escreve Hegel em 1802, o "poder de unificação desapareceu da vida dos homens, e as oposições perderam sua relação viva e ação recíproca [lebendige Beziehung und Wechselwirkung]" (DS, p. 22).

A filosofia kantiana, dona do espírito que orienta essas demais filosofias da reflexão, exprimia de maneira clara a unificação como necessidade suprema da filosofia, muito embora, devido ao predomínio do pensar reflexivo conduzido por um entendimento distintamente oposto à sensibilidade, não fosse capaz, ela mesma, de ir além da oposição, "que ora é apreendida como espírito e mundo, ora como alma e corpo ou também como eu e natureza, etc." (GuW, p. 302). O caráter sintético de seu saber transcendental era assim transformado em um saber meramente formal, para o qual a ligação (Verbindung) entre a identidade abstrata da categoria e a multiplicidade empírica permaneceria inexoravelmente presa a um aspecto de "incompreensibilidade" (Unbegreiflichkeit) (GuW, p. 328-29). Toda forma de unificação completa desses opostos

\footnotetext{
${ }^{1}$ Cf. HW II, GuW, pp.287-301.
} 
que pretendia dar conta daquele "gigantesco império empírico da sensibilidade e percepção", aquela "aposteridade absoluta" (DS, p. 10) que não se conformava às restritas doze categorias do entendimento, era para ela somente um "postulado universal e subjetivo a não ser realizado" (ein allgemeines subjektives, nicht zu realisierendes Postulat) (GuW, p. 302), isto é, uma idéia regulativa que, sem nenhuma objetividade verdadeira - porque sempre remetida a exigências puramente subjetivas de organização do saber ${ }^{2}$ - somente poderia ser concebida como uma "tarefa inifinita" de um "deverser”, jamais, porém, totalmente realizável. Tendo tornado previamente subjetiva toda a objetividade que pode ser reconhecida enquanto tal ${ }^{3}$, a filosofia de Kant representa, aos olhos de Hegel, um "malogro" 4 por não poder realizar a tarefa da "verdadeira filosofia". Como veremos, esse diagnóstico é tanto mais intensificado quanto mais próxima essa mesma filosofia chegou da possibilidade de expressar apenas aquilo que tem de autêntica filosofia, o seu princípio especulativo.

Ser uma verdadeira filosofia, temática central dos trabalhos de Hegel na época de Jena, é o que orienta toda uma leitura que procura reconhecer o sucesso de um sistema filosófico na sua correspondência à necessidade (Bedürfnis) que tem por base. Hegel irá censurar a impossibilidade de apreensão, expressão e conservação do absoluto no sistema kantiano. Esta censura revelará, por outro lado, a reabilitação que a filosofia terá aos olhos de Hegel a partir de sua estada em Jena, dado que até seu último escrito de Frankfurt, a reflexão filosófica era reconhecida apenas em seu aspecto negativo e restritivo. $\mathrm{Na}$ época dos Entwürfe über Religion und Liebe (1797-1800) e, posteriormente, do Systemfragment (1800), a filosofia esteve sempre associada, em conformidade com seu sentido tradicional, aos processos de abstração e de universalização conceitual próprios à reflexão, que mantém os termos relativos em oposição (universal, particular; condição, condicionado; determinante e determinado, etc.). A filosofia, que é um pensar, estava nessa medida relacionada necessariamente com aquilo que ela pensa, mas sempre na distância (separação) de seu objeto: "um pensado

\footnotetext{
${ }^{2}$ Cf. GuW, p. 322; também cf. Kant, KrV, B 702.

${ }^{3}$ Cf. Lebrun, L'antinomie et son contenu. In: Revue Internationale de Philosophie $\mathrm{N}^{\circ} 4 / 1999$, p. 507-508. Cf. Hegel, WdL, HW V, p. 40.

${ }^{4} \mathrm{O}$ termo "malogro" (ratage) é tomado de empréstimo de Lebrun, (L'antinomie et son contenu, p. 534), e será abordado em pormenor no primeiro capítulo.
} 
[ein Gedachtes] é um separado, contraposto ao pensante" (HW I, p.252). Para a filosofia seu objeto, o absoluto, deveria portanto permanecer, por definição, inapreensível.

Todavia, como pretendemos indicar no decorrer de nosso trabalho, a reabilitação da filosofia a partir de 1800 representará uma reinterpretação do papel da reflexão na tarefa de apreensão do absoluto, que se realizará a partir de uma análise do conceito de "vida" (Leben), princípio de unificação desenvolvido em Frankfurt. Se Hegel inicialmente recusa ao pensamento reflexivo a possibilidade de pensar a dinâmica própria da vida, isso se devia ao fato de que o modelo de reflexão que ele possui antes de sua mudança para Jena ser aquele conduzido pela "reflexão finita" do entendimento, tal como a filosofia crítica de Kant apresentara. Esta reflexão finita, que respondia diretamente aos pressupostos da filosofia crítica que a colocava em marcha, não podia acessar uma esfera para além da finitude do conhecimento, excluindo assim toda espécie de saber especulativo para além dos contornos da subjetividade finita. Na medida em que o pensar era identificado à reflexão finita, tal como ocorria no interior da filosofia de Kant, não poderia haver um saber do absoluto, isto é, um conhecimento absoluto que não deixasse de sê-lo na medida mesma em que era inevitávelmente remetido à subjetividade do homem. Sem um aprofundamento do sentido da reflexão que a libertasse dos partis pris da filosofia crítica, e que se caracterizasse como um ultrapassamento de seu aspecto unilateral e finito, Hegel não poderia desenvolver uma outra forma de pensar, aquela que será por ele chamada de especulação.

A partir desse aprofundamento da reflexão do entendimento, Hegel poderá elevar a reflexão finita do entendimento a uma reflexão da razão, reconhecendo-a como possuindo um novo estatuto, não meramente negativo no conhecimento do absoluto. Da "má reflexão" 5 que se contrapõe ao absoluto, Hegel desenvolvera a concepção de uma reflexão especulativa como instrumento da filosofia na tarefa de apreensão do absoluto. Através dessa reinterpretação especulativa da reflexão, a expressão "fillosofias da reflexão" ganha novos contornos, passando a ser ela própria o signo daquela tensão anteriormente indicada, na medida em que traz em si mesma, de modo expresso, ambas as tendências do interior do sistema kantiano: de um lado a de ser uma "filosofia da reflexão", que enquanto filosofia não consegue se realizar no sistema e fracassa devido ao

\footnotetext{
${ }^{5}$ Hegel, Aphorismen aus Hegels Wastebook [1803-1806], HW II, p. 554.
} 
caráter dominador da limitação e da reflexão do entendimento (GuW, p. 388) instaurando, definitivamente, uma distância intransponível, um abismo entre o homem e o absoluto. E de outro lado, o de ser uma "filosofia da reflexão", isto é, o de enunciar idéias especulativas sem poder reconhecê-las, o que somente pode ser percebido por uma leitura que não compartilhe dos mesmos pressupostos que seu sistema.

A leitura hegeliana tem assim esses "dois espíritos da filosofia kantiana” (VSPh, p. 269) em vista e pretende desenvolver sua crítica a partir dessa perspectiva. A limitação da filosofia kantiana a uma não apreensão daquilo que de especulativo seu próprio texto tem a revelar é o que a leitura especulativa terá diante de seus olhos. Como a razão age conforme seu interesse, Hegel sabe que o entendimento só pode ser vitorioso na sua luta com a razão na medida em que esta renunciar a si mesma ${ }^{6}$. Isso significa reconhecer que mesmo no interior de uma época de Entzweiung, e das restrições impostas pelo entendimento de maneira fixa e estabilizada ${ }^{7}$, ainda é a razão que age no estabelecimento das unidades que as categorias incorporam, assim como ainda é ela, na sua correspondência a um "fator da vida" (DS, p. 21), que cinde para depois poder reunir. Ou seja, como escreve Hegel, é no seu "próprio domínio" que o entendimento "pode ser atacado", isto é, pode ser reconhecido como não tendo a autonomia que se auto-imputa. A tarefa da leitura especulativa da filosofia de Kant que Hegel realiza será, então, a de mostrar como mesmo ali onde o entendimento parece dar a última palavra, ele já está sob uma "atuação secreta da razão" (DS, p. 26), de modo que no interior de sua própria atividade se encontra o princípio de sua "destruição".

Aquilo que caracterizará a especulação será, portanto, esse olhar, que no seu descolamento e sua distância do entendimento, reconhece (erkennt) esse autoaniquilamento do entendimento e pode assim efetivamente suprimi-lo (aufheben), sem

\footnotetext{
6 "Na luta do entendimento com a razão vem àquele uma força, somente na medida em que esta renuncia a si mesma; o sucesso da luta depende, por isso, dela própria e da autenticidade da necessidade, da qual ela surge, de restabelecer a totalidade". Hegel, DS, p. 24.

7 "Na situação da cisão a vida humana se movimenta num mundo de oposições e limitações fixas. Ela tem seu mundo como um âmbito de determinações isoladas e unívocas, no qual cada uma é limitada e assegurada pela outra. Trata-se de um mundo de total estabilização [eine Welt der totalen Beruhigung], no qual o entendimento - para Hegel aqui idêntico ao entendimento comum - tem a absoluta condução: ele estabelece a 'indiferença da segurança', a universal 'fixação' o apoio nas 'seguras posições', 'com as quais o homem racionalmente vai vivendo a vida', e 'das quais ele parte e para as quais ele retorna'". Marcuse, H. Hegels Ontologie und die Theorie der Geschichtlichkeit, p. 10.
} 
que seu resultado seja a pura negatividade. No entanto, o que os esforços de Hegel visam mostrar é como não basta indicar essa origem racional do agir do entendimento se não se romper definitivamente com o que G. Lebrun chamou de o "preconceito da finitude" 8 que reiteradamente sabota a própria razão. A filosofia kantiana será, na perspectiva de Hegel, a expressão maior dessa sabotagem: nela "se o entendimento foi tratado com razão, a razão, pelo contrário, é tratada com entendimento" (DS, p. 10), e os méritos de uma apreensão racional do entendimento são previamente arruinados, pois essa razão já não era mais razão, mas estava de antemão despotencializada ao nível do entendimento. O esforço da filosofia hegeliana no período inicial de Jena será o de tratar o entendimento com razão, isto é, em sua verdade e para além de si mesmo, sem tomar antecipadamente a razão como entendimento - círculo do qual a filosofia kantiana não podia sair.

O que pretendemos mostrar em nosso trabalho é como será inevitável para o acompanhante do esforço da crítica hegeliana ser tomado pelo seu aspecto "monótono" e "cansativo" " se ele não se ativer cuidadosamente para o que ali efetivamente está em jogo. Não se trata de uma repetição à exaustão da simples oposição entre os limites das filosofias da reflexão e do seu fracasso em apreender o racional em relação aos poucos apontamentos de idéias especulativas ali indicadas. O que Hegel realiza nesses textos é, antes, uma transformação semântica dos conceitos específicos dessas filosofias através de uma reinterpretação especulativa do aspecto positivo que, embora pressuposto, permanece oculto por de trás do "raciocinar negativo" que floresce nesses sistemas. Não se trata, portanto, de uma repetição como que na defesa de um partido político, mas antes na exigência desse movimento para revelar o que de racional ali teima em se esconder.

Portanto, insistimos no fato de que a própria leitura de Hegel não pretende ser uma recusa da filosofia de Kant, ou de qualquer forma de pensar expressa nas mais diversas tendências e filosofias às quais Hegel se dirige em sua crítica; tampouco se trata de uma simples seleção do que de cada filosofia é válido conservar - o que pode ser sugerido por um olhar rápido, mas que no entanto revela-se um equivoco grave de interpretação, tendo em vista a compreensão que Hegel tem da própria idéia de filosofia;

\footnotetext{
${ }^{8}$ Lebrun, G. A Paciência do Conceito, p. 194.

${ }^{9}$ Cf. Haym, R. Hegel und seine Zeit, p. 189.
} 
trata-se, antes de tudo, de uma leitura comprometida em compreender a especulação não como uma maneira filosófica qualquer de 'abordar' o absoluto, mas uma maneira absoluta de abordar a filosofia.

Estrutura do trabalho

A abordagem deste trabalho não segue uma ordem cronológica dos textos de Hegel, mas sua organização busca explicitar como o conceito de especulação, conquistado através da experiência intelectual hegeliana, e em confronto com a reflexão kantiana, retroage em sua própria leitura desta filosofia. Por esse motivo, nosso trabalho tem um percurso circular, e parte da análise de textos que apenas em um segundo momento são retomados a fim de ilustrar o desenvolvimento dos aspectos especulativos extraídos da filosofia de Kant.

O que buscamos desenvolver na primeira parte do trabalho é uma aproximação do que se poderia chamar de "hermenêutica hegeliana" ${ }^{10}$, na busca de uma compreensão adequada do significado da expressão "Hegel leitor". Abordamos nesse capítulo inicial algumas das reiteradas acusações dirigidas ao filósofo reunidas na denominação geral de dogmatismo, voltando-nos à especificidade de sua leitura de Kant. Nosso primeiro passo é o de desfazer uma compreensão de um suposto dogmatismo de leitura hegeliano, acusação que na maior parte das vezes impede um acesso verdadeiro a ela e age mais como uma recusa a esse contato do que como um juízo feito a partir dele. Damos assim uma especial importância a essa investigação daquilo que G. Lebrun chamou de a "arte de ler hegeliana" ${ }^{11}$, não por mero academicismo ou preocupações metodológicas exageradas, tampouco para defendê-lo de acusações que ele não pôde prever ${ }^{12}$; o que buscamos mostrar é como é precisamente na sua maneira de ler a filosofia kantiana que se pode reconhecer o nascimento da perspectiva que Hegel chama de especulação.

\footnotetext{
${ }^{10} \mathrm{O}$ termo é tomado de empréstimo de A. Philonenko, Introduction à Foi et Savoir. In: Hegel, Foi et Savoir, Vrin, p. 13.

${ }^{11}$ Lebrun G. Lebrun, L'antinomie et son contenu. In: Revue Internationale de Philosophie $\mathrm{N}^{\circ} 4 / 1999,520$ trad. p.596.

${ }^{12}$ Lebrun, G, A Paciência do Conceito, p. 406 "O enigma permanece: nunca se critica Hegel sem se expor a lhe endereçar queixas que, na verdade, ele teria tido o descuido de não prever".
} 
No interior dessa discussão abordamos a concepção que Hegel apresenta de crítica filosófica em seus textos do Jornal Crítico de Filosofia. Procuramos com isso alcançar os critérios e medida adequados para podermos acessar sua leitura específica da filosofia kantiana, tendo já como horizonte para nossa investigação a noção de especulação que começa a ser forjada a partir dos impasses que ali são reconhecidos, assim como da necessidade da época e do interesse da razão. Trabalhando com essas concepções centrais de seus escritos na época ("necessidade da filosofia", "interesse da razão", a oposição entre "filosofia verdadeira" e não-filosofia), buscamos compreender como se dá a relação entre a verdadeira filosofia que se apresenta no sistema kantiano e aquilo que no sistema kantiano não pode suportar o que há de especulação autêntica.

Para tanto, apresentamos em seguida a crítica que Hegel faz à apreensão da situação filosófica de sua época feita por K. L. Reinhold, discutindo em especial suas considerações acerca de como abordar uma filosofia passada. Essa passagem pela crítica a Reinhold tem um sentido estratégico no Differenzschrift que pretendemos ressaltar. Exaltado pelo seu "espírito sistemático", Reinhold representa uma "continuação" de Kant que enfatiza precisamente o oposto daquilo que Hegel considera "propriamente promissor em Kant" ${ }^{13}$. Nesse sentido Reinhold será abordado como aquele que não pôde ter em vista a tensão que é objeto constante do olhar especulativo: aquela que ora se configura entre a filosofia de Fichte e a de Schelling, objeto do escrito de 1801 de Hegel, ora entre dois aspectos interiores à filosofia de Fichte e à filosofia de Kant; ou então aquela, na sua configuração geral, entre especulação e entendimento comum (gemeiner Verstand). Essa lição hegeliana acerca de como se fazer filosofia ou história da filosofia - o que, especulativamente compreendido, tem de ser o mesmo - será fundamental para o nosso percurso, que através de uma re-apropriação da noção de sistema nos abrirá o campo para abordarmos a reinterpretação especulativa da noção de reflexão.

No capítulo seguinte, abordamos as críticas que Hegel faz às "filosofias da reflexão", classificação que compreende como figuras maiores as filosofias de Kant, Fichte e Jacobi. Seguindo o texto de 1802, Fé e Saber, buscamos mostrar como Hegel reconhece nessas filosofias a expressão maior de uma situação histórica caracterizada pela contradição nas mais diversas esferas da vida humana. Ressaltamos nesse capítulo

${ }^{13}$ Haering, T. Hegel. Sein Wollen und sein Werk, I, p, 611. 
como, em todas essas dimensões, a razão é apresentada na sua impotência e fixada em uma configuração finita que a mantém à distância do absoluto, entendido como princípio de unificação viva de todas essas esferas. Para Hegel, o resultado negativo dessas filosofias se expressa de maneira mais nítida através do poderoso estatuto que elas concedem à fé, que nada mais exprimiria do que a resignação do saber do absoluto, ou nas palavras de Hegel, a "morte da filosofia” (GuW, p. 289). Ao longo desta discussão, procuramos indicar como o diagnóstico feito por Hegel contém em si uma ambigüidade que a própria expressão "filosofia da reflexão" parece enunciar. Se nas filosofias submetidas ao "princípio de subjetividade" e à finitude do saber, a razão se encontra rebaixada aos limites do entendimento, e o pensar identificado à reflexão finita, tal como Hegel reconhece ocorrer, por outro lado a negatividade atribuída à subjetividade permite com que essas filosofias apresentem o "significado negativo do absoluto", afastando-se assim das "metafísicas da objetividade" (GuW, pp. 430, 432), para as quais não há como vislumbrar qualquer forma de conhecimento absoluto.

A partir da ambigüidade reconhecida por Hegel, adentramos, em seguida, na filosofia kantiana, visando reconhecer em que medida a filosofia kantiana pode ser reconhecida como uma filosofia da reflexão; trata-se da investigação acerca da relação que a crítica mantém com a atividade reflexiva. Num primeiro momento, buscamos indicar como a reflexão crítica, que organiza a filosofia kantiana, tem um sentido eminentemente negativo no que diz respeito ao conhecimento, e como sua função maior no interior do projeto crítico concentra-se na tarefa de limitar as pretensões de todo conhecimento especulativo. A partir do reconhecimento disso, o esforço de nossa análise é o de mostrar que muito embora a reflexão seja a operação fundamental da crítica, nem toda forma de reflexão tem necessariamente de responder aos pressupostos críticos, tal como ocorre na fillosofia de Kant. Essa não imediata identificação da reflexão à crítica é o que caracteriza a tensão que Hegel pode encontrar no próprio texto kantiano.

Dessa tensão presente na reflexão kantiana, Hegel passa ao reconhecimento de uma exigência de aprofundamento da reflexão, de modo a libertá-la da interpretação que a limita a uma atividade meramente negativa, tal como Hegel encontra na filosofia crítica. Buscamos assim indicar como essa exigência de ultrapassamento da reflexão finita já encontra expressão na Crítica da Faculdade do Juízo, obra na qual Kant anuncia 
um novo significado para a atividade reflexiva, e que será fundamental para reinterpretação especulativa da reflexão realizada por Hegel. Na terceira crítica, ele pode encontrar as raízes de uma superação da interpretação finita da reflexão e caminhar em direção a uma interpretação especulativa da reflexão, para a qual será possível então um conhecimento positivo do absoluto, tema central de seus escritos de Jena.

A transformação gradual do sentido da reflexão é o que acompanhamos no capítulo seguinte, a partir de uma análise dos textos de Hegel do final do período de Frankfurt, tematizando em pormenor o esforço da reflexão finita em pensar a vida, considerada como um princípio dinâmico de unificação de termos contraditórios. Através de uma análise do Fragmento de Sistema de 1800, visamos indicar como a filosofia e seu pensar separador, que à época ainda se mostravam para Hegel incapazes de apreender a unidade viva da vida, todavia já possui uma participação importante no movimento de sua apreensão numa esfera religiosa. Este último fragmento do período de Frankfurt tem, porém, uma especial importância na medida em que não recusa simplesmente a reflexão do entendimento, como ocorria nos textos anteriores, mas procura apresentar conceitualmente, isto é, reflexivamente as suas deficiências. Esse curioso procedimento do Systemfragment é o que permite revelar como a reflexão abre a si mesma um âmbito que a ultrapassa, "um ser exterior da reflexão" (SF, HW I, p. 422), mas que depende dela para se constituir enquanto tal. Isso representará, como pretendemos mais detidamente indicar, um passo decisivo na transformação semântica da reflexão, na medida em que ali se anuncia o surgimento de um modo de pensar que não deixa de ser também reflexão, mas que não mais se encontra reduzido à mera reflexão, reflexão finita. Localizamos aqui, então, o nascimento ainda não declarado de uma nova postura em relação à reflexão, ao pensar, e à filosofía.

Essa nova postura Hegel experimenta como a exigência e o impulso para a formação de um sistema de caráter científico e que assumisse, portanto, a "forma da reflexão", como Hegel se expressa em carta a Schelling acerca da transformação que reconhece em seu pensamento ${ }^{14}$. Esse é o tema de nosso capítulo seguinte, no qual abordamos o sentido deste novo estatuto da reflexão no conhecimento do absoluto, sua

\footnotetext{
14 "Em minha formação científica, que começou com necessidades subordinadas dos homens, tive de ser impelido para a ciência, e o ideal de juventude teve de se transformar na forma da reflexão ao mesmo tempo em um sistema" Briefe von und an Hegel, (02.11.1800), Band. I, pp. 59-60.
} 
interpretação especulativa. Trata-se de mostrar como essa nova perspectiva permite reconhecer no interior da negatividade da reflexão o lado positivo de sua atividade, ou, em outras palavras, reconhecer a sua negatividade enquanto momento necessário do positivo.

Retornamos assim ao Escrito da Diferença de 1801, onde buscamos apresentar como a perspectiva especulativa transmutará a "reflexão isolada" e isolante das filosofias do entendimento em "reflexão filosófica", isto é, enquanto um instrumento do filosofar, compreendida agora em sua tarefa positiva. A partir daqui a reflexão será apreendida através da "lei de seu auto-aniquilamento" (DS, p. 43) e poderá (deverá!) ser um momento essencial na realização da tarefa da filosofia, a partir disso enunciada como a construção do absoluto para a consciência. Termo que também sofrerá uma reinterpretação na nova semântica especulativa, a "construção" (Konstruktion) não estará mais restrita ao âmbito dos conceitos puros da matemática, como Kant o fizera, mas será especulativamente compreendida como o próprio fazer filosófico de acordo com sua tarefa assumida no interior de uma "cultura da reflexão". Hegel sabe que a única maneira de restituição do absoluto numa "cultura do entendimento" somente pode se dar através da potência inscrita na própria reflexão que a domina e no interior de sua exigência de uma construção para a consciência. Veremos como isso implica em uma reabilitação da noção de consciência que, desde a época em que Hegel esteve diretamente alinhado à Vereinigungsphilosophie, aparecia como absolutamente oposta a qualquer forma de apreensão do absoluto.

Por fim, na parte final de nosso trabalho, pretendemos recolher as noções especulativamente reinterpretadas, e indicar como é somente através delas que Hegel poderá reconhecer o "lado positivo" 15 da filosofia kantiana, aquele que verdadeiramente pode "interessar" 16 por conter em si a "semente do especulativo" (Keim des Spekulativen). Nessa parte final analisamos os momentos da filosofia kantiana que o olhar especulativo permite reconhecer como os pontos mais elevados a que chega essa filosofia, precisamente ali onde o "princípio da especulação" ou "a identidade de sujeito e objeto" ganha silenciosa expressão (DS, p. 10). Abordamos a título de ilustração deste

\footnotetext{
${ }^{15}$ Cf. Hegel, VGPh, HW XX, p. 253; e, também, Enzy, HW VIII, §46, p. 123.

${ }^{16}$ São diversas as passagens em que Hegel fala do aspecto "interessante" e "importante" da filosofia de Kant. Cf, por exemplo: GuW, p. 328; VSPh, HW II, 268; VGPh, HW XX, p. 358.
} 
procedimento de leitura hegeliano o conteúdo especulativo enunciado nos juízos sintéticos a priori, na imaginação produtiva e no entendimento intuitivo, todos reunidos na sucinta apreciação feita por Hegel em Fé e Saber (1802).

Esse trajeto geral percorrido permite compreender como a noção de especulação pôde surgir do desenvolvimento da ambigüidade presente na reflexão kantiana, conseguindo destacar de sua insistente interpretação finita, uma simultânea potência enunciadora de um sucesso que, todavia, permanece irrealizável nos contornos da filosofia crítica. Essa compreeensão que Hegel tem da filosofia de Kant é assim, a um só tempo, o resultado de um olhar que já não se mantém preso aos limites no interior dos quais a reflexão permanece exterior, isolada e finita, como também resultante do próprio surgimento positivo da filosofia especulativa que nesse processo se realiza. 


\title{
CAPÍTULO I
}

\section{HEGEL LEITOR DE KANT: "A ARTE DE LER}

\author{
HEGELIANA"
}

“Observo apenas que não é nada incomum, tanto na conversa comum como nos escritos, através da comparação de pensamentos que um expressou sobre seu objeto, compreendêlo até mesmo melhor do que ele mesmo se compreendeu na medida em que não determinou suficientemente seu conceito e assim por vezes falou ou até pensou contra a sua própria intenção" Kant, Kritik der reinen Vernunft, B 370.

"O espírito vivo que habita em uma filosofia exige, para se revelar, nascer por intermédio de um espírito aparentado" (Hegel, Differenzschrift, p. 16)

Em um texto que pretende dimensionar a influência de Kant na filosofia de Hegel, M. Gueroult apresenta como especificidade da leitura hegeliana a supressão de "toda a metodologia histórica positiva". Ele afirma que "o hegelianismo se substitui à realidade concreta; os sistemas são pouco a pouco despojados de sua substância própria e isso que resta em cada um de seu esqueleto é preenchido, proporcionalmente à sua potência, de uma só e mesma "filosofia especulativa"” ${ }^{17}$. Não há dúvida de que partindo dessa compreensão acerca da leitura de Hegel, a pergunta que Gueroult pretende responder em seu artigo, a saber, "qual é a dosagem de elemento especificamente kantiano nessa influência?" parece não poder receber outra resposta senão a de que essa influência se reduziria a quase nada ${ }^{18}$, uma vez que os reconhecidos méritos da filosofia crítica, os

${ }^{17}$ Gueroult, M. Le Jugement de Hegel sur l'Antithétique de La Raison Pure. In: Revue de Metaphysique et Morale, 1931, p.414

${ }^{18}$ Idem, p. 438. 
quais Hegel ressalta ao longo de sua obra, não caberiam propriamente a Kant, mas antes a um "Kant hegelianizado" 19 , para usar o termo do próprio Gueroult. Esse parece ser o diagnóstico necessário para esse enfoque que, reconhecendo a distância entre o ponto de vista especulativo e o ponto de vista crítico, não poderia julgar a apreensão que Hegel faz de um "lado positivo" da filosofia crítica senão como resultado de uma deturpação do "kantismo real da história", um efeito direto do assim chamado dogmatismo de leitura hegeliano.

Parece haver um consenso de que uma das características que se sobressaem da chamada "hermenêutica hegeliana" - que desde seu primeiro ensaio crítico de 1802 (Fé e Saber) dirigido a Kant e às filosofias da reflexão já se encontra com princípios claramente destacáveis ${ }^{20}$ - é a de um certo processo de "retranscrição" da filosofia à qual ela se volta em sua crítica filosófica. Essa retranscrição é indicada por diversos intérpretes através de expressões como "reconfiguração" (Umgestaltung) do horizonte de uma filosofia, "deslocamento de problemas", “dissimulações de certos temas", ou até, no caso específico da leitura de Kant, da "mudança de interpretação dos conceitos kantianos" 21 (Uminterpretation, Déplacement) e também de uma "subversão da Crítica [da razão pura], da qual Hegel era perfeitamente consciente" 22. O que está em jogo nessas expressões, no que diz respeito a Hegel leitor de Kant, não se resume apenas à longa e discutida questão de haver ou não uma continuidade no progresso de Kant a Hegel, no sentido de uma evolução de um mesmo problema - tal como a obra canônica de R.

\footnotetext{
19 “Ainsi ce n'est pas Kant, c'est um Kant hégélianisé au deuxieme degré qui va féconder la pensée hégélienne." Gueroult, M. op. cit, p. 424

${ }^{20} \mathrm{Em}$ sua introdução à tradução francesa Philonenko apresenta seis princípios da hermenêutica hegeliana que já estariam presentes desde suas obras de 1802. Cf. Introduction a la [ Foi et Savoir], p. 15.

${ }^{21} \mathrm{~W}$. Bonsiepen se refere a isso como "Uminterpretation Kantischer Termini" (Der Begriff der Negativität in den Jaener Schriften Hegels, p. 69); igualmente, A. Stanguennéc usa a expressão "Déplacement des concepts kantiens", Hegel critique de Kant, (p. 66) e A. Philonenko escreve sobre o "déplacement hégélien", Introduction a la [Foi et Savoir], p. 25. H. Marcuse, em Razão e Revolução, denomina essa alteração conceitual de "reinterpretação dialética", p. 50. K. Düsing, por sua vez, fala em "Umdeutung" da questão kantiana. Das Problem der Subjektivität in Hegels Logik, p. 110. E R.P. Horstmann fala em "Umwertung des begrifflichen Apparats der von Kant in den drei Kritiken vorgestellten Theorie", Den Verstand zur Vernunft zu bringen. Hegels Auseinandersetzung mit Kant in der Differenz-schrifft, p. 101.

${ }^{22}$ Lebrun, G. L'antinomie et son contenu, p. 513. Trad. 575
} 
Kroner pretende apresentar ${ }^{23}$-, mas sim em que medida Hegel pôde realmente ler a filosofia kantiana, pôde apreendê-la em seu projeto próprio. Trata-se, portanto, de um questionamento que, voltado menos ao conteúdo específico de debates pontuais entre ambas as filosofias, dirige-se sobretudo à maneira especificamente hegeliana de abordar um outro sistema de filosofia, tematizando assim a relação entre filosofia e história da filosofia na perspectiva de Hegel.

Philonenko, o tradutor do ensaio de 1802 para o francês, ao buscar esclarecer os princípios da hermenêutica hegeliana à época dos primeiros textos de Jena, reconhece de imediato, no que tange à leitura da filosofia kantiana, a inadequação da tese continuísta ao afirmar que "a problemática kantiana e a problemática hegeliana divergem absolutamente" ${ }^{24}$, e a partir disso, visa indicar como Hegel "conscientemente faz agir sua própria filosofia" na leitura de Kant, apontando como, desse ponto de vista, sua crítica seria externa. Philonenko chega a afirmar que, ao se "dar liberdades até certo ponto inacreditáveis" em relação à proposta kantiana, Hegel passaria ao largo da teoria transcendental kantiana, sobrepondo à lógica da função a lógica da substância, que - a partir da perspectiva kantiana do que essa seria - a filosofia crítica teria pretendido haver superado. Esse modo de abordar as teses de Kant justificaria então a constatação do tradutor de Fé e Saber de que haveria, por parte de Hegel, "um incrível mau conhecimento do projeto kantiano", no sentido de que ambos falariam línguas com semânticas distintas, de forma que o debate real entre ambas as filosofias encontrar-se-ia necessariamente mediado por algumas homonímias e equívocos de compreensão. Seria como se, para usar uma comparação ali feita, não sem algum humor, alguém ao ler o termo "Fenomenologia" na obra de Hegel, limitasse sua compreensão à definição fornecida por Lambert, o primeiro a utilizá-la.

Essa constatação de que Hegel permaneceria à distância do projeto que o texto kantiano apresenta, apesar de se calcar na afirmação peremptória de que não se trata de

\footnotetext{
23 "Por mais que o idealismo de Kant possa se diferenciar do hegeliano; por mais que aquilo que Kant chame de idéia e ideal possa ser tão distinto do sentido das mesmas palavras quando Hegel as emprega; na consonância lingüística deve se anunciar uma igualdade objetiva [sachliche Gleichheit]. A direção tomada por Kant, que ele mesmo denomina de idealismo transcendental, deve ser a mesma na qual se movimentam todos os pensadores que pertencem ao desenvolvimento de Kant até Hegel”. Kroner, Von Kant bis Hegel, I, p.7

${ }^{24}$ Philonenko, A. Op. cit, p. 25.
} 
uma evolução continuista de Kant a Hegel, dificilmente resistiria àquela acusação de dogmatismo de leitura, que nada mais é do que a afirmação da potência do espírito hegeliano em se sobrepor a uma filosofia, ao invés de aceitar, através de uma leitura supostamente mais consistente, o que de fato estaria ali apresentado. Mas será que uma vez reconhecida a superficialidade da tese "continuísta" - segundo a qual a filosofia especulativa seria uma espécie de extensão ou mesmo um acabamento da Crítica restaria somente a possibilidade de atribuir as potencialidades encontradas na filosofia de Kant aos abusos da leitura de Hegel? Será que a distância que o programa especulativo mantém com o projeto crítico o impediria em absoluto de realizar uma leitura imanente da mesma, isto é, não dogmática e que, na sua consciente diferença, não abandonasse o texto de Kant, de modo que as subversões, deslocamentos e reinterpretações conceituais teriam de ser inevitavelmente compreendidas como a pujança de uma certeza doutrinaria e de verdades previamente estabelecidas sobre uma outra filosofia ${ }^{25}$ De que forma, enfim, poder-se-ia medir a distância de um discurso em relação a outro se a medida para isso fosse de antemão vista e concebida através dos signos de "má compreensão" ou de "liberdades inadmissíveis"?

G. Lebrun, na contramão do artigo de Gueroult, se esforça em resguardar a legitimidade da "arte de ler hegeliana" sem ter de recair, de outro lado, na necessidade de pressupor uma passagem ininterrupta entre ambos os sistemas, e isso nem da perspectiva do próprio Hegel, como Gueroult pensa ser o caso nos textos posteriores a 1808: "O autor da Lógica leu Kant com demasiado cuidado para poder sugerir que a filosofia especulativa é, no que quer que seja, o acabamento da Crítica. Mesmo quando reconhece que a Crítica marcou um momento importante, ele não a apresenta como premonitória da compreensão conceitual” ${ }^{26}$. Como pretende mostrar Lebrun, não há afinidade entre a filosofia especulativa e a Crítica, nem "pontos de tangência" que ultrapassem a figura de uma "similitude fugidia", muito embora seja inegável o ensejo

\footnotetext{
${ }^{25}$ Cf. K. Düsing, por exemplo: “A crítica de Hegel a Kant não é, portanto, imanente, mas parte de interpretações que apenas são significativas para seu próprio projeto de lógica e metafísica”. $O p$. cit., p. 119.

${ }^{26}$ Lebrun, Gérard. L’ antinomie et son contenu, p. 533. Trad. 594.
} 
que a filosofia de Kant proporciona a Hegel de diagnosticar o malogro de uma filosofia que "todavia tinha todos os meios de construir um pensamento da reconciliação" 27.

Segundo a tese de Gueroult, aqui combatida por Lebrun, haveria um "ponto de contato" entre Kant e a filosofia especulativa apenas no Hegel da Ciência da Lógica, uma vez que ali "a imagem do kantismo é seriamente transformada", e que aquilo que em $F e ́ e$ Saber aparecia como "estéril", em especial a Antitética da razão pura, em 1812, ao contrário, poderá ser reconhecido em sua "natureza positiva", devido menos a uma influência real do kantismo e mais a um "Kant hegelianizado", produto da maneira hegeliana de ler. ${ }^{28}$ Interpretação essa que se fundamenta na afirmação de que o Hegel da Wissenschaft der Logik, ao ler a Crítica da Razão Pura, teria ali encontrado "uma primeira imagem da razão concreta" ${ }^{29}$, que caberia à filosofia especulativa, em seguida, depurar e desenvolver.

O que Lebrun pretende pôr em xeque na tese de Gueroult não é tanto a sua “conclusão 'descontinuísta", mas a "posição continuísta que ele [Gueroult] atribui a Hegel" 30 , afirmando que o autor da Lógica jamais "acreditou descobrir na Antitética as primícias de uma razão concreta" e que, portanto, a filosofia kantiana e a especulativa possuem "discursos bem exatamente transversais", tanto em 1802 quanto em 1812. Se a transversalidade dos discursos é reconhecida e a distância entre ambas as perspectivas não é suprimida em nome de um 'Hegel kantianizado' - como parece ser uma tendência nos estudos que retomam a linhagem de Kant a Hegel, e compreendem a filosofia do último como um avanço crítico dos limites da filosofia de Kant, em especial da sua filosofia moral $^{31}$-, Lebrun parece nos oferecer a possibilidade de pensar "a arte de ler hegeliana" a partir de uma atitude que muito se afasta da rápida acusação de dogmatismo

\footnotetext{
${ }^{27}$ Alain Renaut, apud Lebrun, op. cit, p. 534

${ }^{28}$ É importante indicar como esse argumento de uma transformação na imagem da filosofia kantiana para Hegel, que se fundamentaria na reinterpretação das antinomias e seu "valor positivo", não parece se sustentar não apenas tendo em vista os elogios feitos à antitética em Fé e Saber, mas também em vista do texto Glauben und Sein da época de Frankfurt - e portanto bem anterior -, no qual já se pode reconhecer os "primórdios do uso positivo das antinomias característico da dialética", como aponta M. Baum. Die Entstehung der hegelschen Dialektik, p. 48.

${ }^{29}$ Gueroult, M, Op. cit, p. 425-6.

${ }^{30}$ Lebrun, Gérard. L' antinomie et son contenu, p. 509. Trad. p. 571.

${ }^{31}$ Cf. por exemplo, a importante obra de M. Bondeli, Der Kantianismus der jungen Hegel. (1997)
} 
de leitura. A especificidade da maneira hegeliana de ler é algo que pretendemos em alguns pontos abordar aqui através dessa janela que Lebrun nos abre.

Para isso, no que se refere à leitura específica da filosofia de Kant, deve-se, pois, distinguir e evitar tomar de pronto ambas as interpretações apresentadas por Gueroult: seja aquela que compreende que aos olhos de Hegel: "a razão kantiana e a razão hegeliana não são mais separadas por suas naturezas, mas por seus graus”, no sentido de que bastaria "pressionar o sistema kantiano para que dele saia, como de si mesmo, a dialética hegeliana" ${ }^{32}$; ou aquela outra interpretação que atribui o ponto de contato dessas filosofias a um mau julgamento de Hegel e aos efeitos de um total "despojamento" da "substância própria" à filosofia de Kant seguido de um preenchimento de filosofia especulativa capaz de esconder as irredutibilidades entre ambas. Tanto a primeira interpretação - que na assimilação da razão hegeliana com a kantiana, divergidas somente no grau de sua efetivação, acaba por identificar ambos os projetos, e necessariamente desconhecê-los -, quanto a segunda interpretação, que acusa o mais radical dogmatismo de Hegel, na medida em que ele se pensa como continuador de uma filosofia que não resiste à sua leitura, não conseguem se aproximar da "hermenêutica hegeliana", de sua maneira própria de ler uma filosofia.

Se não pretendemos assumir de antemão essa censura dominante ao Hegel "historiador da filosofia", e não nos colocamos nós mesmos como dogmáticos - pois como Lebrun bem aponta "Hegel não se pensa como dogmático" ${ }^{33}$, e isso longe de ser uma brincadeira deve ser levado a sério enquanto uma exigência de aproximação da maneira hegeliana de ler; se, portanto quisermos compreender o sentido de Hegel leitor de Kant, devemos seguir como orientação uma passagem em que o jovem Hegel nos indica de que modo se situa sua leitura. No Differenzschrift, (1801) Hegel escreve: "O espírito vivo que habita em uma filosofia exige, para se revelar, nascer por intermédio de um espírito aparentado" (DS, p. 16). Buscamos assim, nesse esforço de aproximação, reconhecer a leitura de Hegel a partir dessa indicação de seu movimento como o de revelação do espírito vivo (lebendiger Geist) que habita uma filosofia. Isso caminha no sentido de mostrar que a idéia de crítica filosófica só poderá ter sentido para Hegel

\footnotetext{
${ }^{32}$ Cf. Gueroult, M. op. cit. p. 425. (O grifo é de nossa autoria)

${ }^{33}$ Lebrun, G. A Paciência do Conceito, p. 15.
} 
enquanto uma tarefa imanente, e que cabe à compreensão do significado dessa imanência a justa apreensão de "Hegel leitor de Kant".

Para esclarecer o sentido dessa imanência devemos abordar dois pontos que se mostram centrais para compreender a medida que orienta a leitura de Hegel, a saber: $\alpha$ ) a idéia da filosofia e de sua tarefa; e $\beta$ ) o diagnóstico de um malogro que pode ser reconhecido através do "projeto clínico" presente no discurso de Hegel. Ambos os pontos são temáticas centrais dos primeiros ensaios de Hegel que se dedicam ao modo de pensar da filosofia e à filosofia kantiana em particular, escritos na primeira fase de sua estada em Jena.

\section{Os dois espíritos da filosofia de Kant.}

Se a compreensão da maneira hegeliana de ler os textos dos filósofos que o precederam traz inúmeras dificuldades, no caso de Hegel leitor de Kant elas parecem se multiplicar ainda mais, haja vista a disparidade de juízos acerca do filósofo de Königsberg presentes, não apenas em diferentes obras, mas em um mesmo parágrafo. $\mathrm{Na}$ Lógica, por exemplo, em um trecho que se inicia com as seguintes palavras: "Kant elevou a dialética na medida em que removeu a aparência de arbitrariedade que ela possui segundo a representação corrente e apresentou-a enquanto um fazer necessário da razãoe esse aspecto é um de seus maiores méritos" (WdL, p. 52) - tudo indica se tratar apenas de um elogio a Kant. Porém poucas linhas abaixo ele prossegue:

"Mas tão logo [Kant] permanece no lado abstratonegativo do dialético, então o resultado é apenas o conhecido, a saber, o de que a razão é incapaz de conhecer o infinito; - um estranho resultado, na medida em que o infinito é o racional, que diz que a razão é incapaz de conhecer o racional" (WdL, p. 52).

Essa postura híbrida, repleta de comentários ambivalentes, certamente não é uma prerrogativa da filosofia de Hegel no cenário pós-kantiano. A tarefa de se realizar uma explicitação das premissas tácitas não enunciadas pela filosofia crítica, tal como encontramos na leitura feita por Reinhold, ou a exigência de se separar o espírito daquela filosofia da letra que ela assumiu na forma kantiana - um recurso reiteradamente usado 
por Fichte - são todas atitudes orientadas por essa "relação ambivalente" ${ }^{34}$ com a obra de Kant, que se constituem como um princípio metodológico que se desenvolve de certo modo até a filosofia de Hegel ${ }^{35}$. Todavia, muito embora a postura de Hegel se assemelhe a esse tópos da crítica a Kant, a leitura que ele faz dessa filosofia, ao longo de toda sua obra, percorre um caminho distinto dessa atitude de seus contemporâneos que no próprio movimento de distanciamento de Kant se reconhecem explicitamente ainda no quadro da filosofia de Kant - atitude essa que Fichte exprime de maneira paradigmática no seu texto programático ao dizer que sabe que jamais poderá dizer algo que Kant já não o tenha feito seja de modo imediato ou não, seja de maneira clara ou obscura ${ }^{36}$.

Hegel, ao contrário, desde bem cedo reconhece que a filosofia kantiana fornece uma perspectiva no interior da qual a realização da tarefa da filosofia se encontra de antemão impossibilitada, isto é, destinada a um "malogro" inevitável ${ }^{37}$. A idéia de malogro é aqui de fundamental importância, pois ela revela que muito embora haja um descolamento da filosofia especulativa em relação aos contornos gerais da filosofia de Kant - sem o qual o reconhecimento de um malogro não seria possível (pois a idéia de malogro pressupõe necessariamente a visão da não realização de uma tarefa) -, essa filosofia pôde à sua maneira anunciar, aos ouvidos daqueles que de algum modo já não estavam mais absorvidos nela, aquilo que ela efetivamente não poderia realizar. De modo que através desse bloqueio anunciado no interior do texto kantiano, Hegel pôde

\footnotetext{
${ }^{34}$ Horstmann, R.P. Die Grenzen der Vernunft, p. 26

${ }^{35}$ Cf. Henrich, D. Between Kant und Hegel..."While no one agreed with Reinhold that he had been able to arrive at the fact that would account for the systematic structure of the mind, all agreed for a while that he had accurately described what had to be done in philosophy (...). The methodological principle that Reinhold articulated governed the development from himself to Fichte, and in turn from Fichte to Schelling, culminating in Hegel" (p. 125).

${ }^{36}$ Em relação a Fichte, conferir por exemplo: Über den Begriff der Wissenschaftslehre, GA I,2, p. 110: "Ele [o autor] sabe que ele jamais poderia dizer algo que já não tenha sido indicado por Kant de modo imediato ou mediato, clara ou obscuramente". Ou também: Versuch einer neuen Darstellung der Wissenschaftslehre, GA I,4, p. 184: "Meu sistema não é nenhum outro senão o kantiano: isto é, ele contém a mesma visão da coisa...". Ou ainda em Zweite Einleitung in die Wissenschaftslehre, GA I,4, pp. 230-31, que reconhece que o "espírito e a alma mais íntima" da filosofia de Kant também eram o mesmo "espírito e a alma mais íntima da Wissenschaftslehre". Em relação a Schelling, por exemplo, Vom ich als Princip der Philosophie...,SW, I, pp. 78-79.

${ }^{37}$ É importante ressaltar que não é a filosofia kantiana considerada em si mesma que está sendo tachada de uma filosofia malograda, mas apenas o sistema kantiano a partir da perspectiva especulativa e da tarefa que esta atribui à filosofia em geral.
} 
vislumbrar simultaneamente qual a tarefa da filosofia ali não realizada, e detectar quais os obstáculos que a frearam.

Dessa forma, o sentido da ambivalência em relação aos feitos kantianos, característica da leitura de Hegel, só pode ser compreendido a partir dessa postura diversa da dos seus contemporâneos, e à luz dessas duas referências centrais: a idéia da filosofia enquanto possuindo uma tarefa e o diagnóstico de um malogro no sistema de Kant. Sem ambas as referências, a própria noção de crítica filosófica, tal como Hegel denomina e compreende uma consideração de um sistema filosófico à época do Jornal Crítico de Filosofia ${ }^{38}$, torna-se claudicante e a sua determinação enquanto filosófica (crítica filosófica) sem sentido. Pois a crítica filosófica, escreve Hegel, "só poderá ter algum sentido para aqueles em que a idéia de uma e mesma filosofia está presente, assim como ela somente poderá dizer respeito àquelas obras nas quais essa idéia pode ser reconhecida como mais claramente ou menos claramente expressa" (ÜWPhK, HW II, p. 173). Isso significa que a leitura hegeliana coloca como exigência de sua "hermenêutica" o voltar-se a um sistema filosófico apenas na medida em que ele expresse de algum modo a idéia da filosofia, ou seja, apenas na medida em que ele seja filosofia e que portanto realize à sua maneira a tarefa que "é a mesma para todas as épocas" (DS, p. 17); apenas então há sentido em se falar em crítica filosófica.

"Onde esta idéia da filosofia está efetivamente presente, escreve Hegel, aí o serviço da crítica [filosófica] (Geschäft der Kritik) é tornar claro a maneira e a intensidade na qual ela surge livre e clara, assim como a extensão na qual ela se elaborou em um sistema científico de filosofia" (ÜWPhK, HW II, p. 174).

Essa crítica filosófica que implica um mapeamento dos pressupostos e condições nas quais a idéia da filosofia pode ser expressa em um determinado sistema ${ }^{39}$ não deve, no entanto, ser entendida como sendo a prática de uma crítica pontual, ou como a simples busca de uma explicitação de princípios ocultos daquele sistema, mas como a determinação atenta da sua possibilidade de realizar ou não a tarefa da filosofia, tendo em

\footnotetext{
${ }^{38}$ Jena, 1802-03 Editado em conjunto com Schelling.

39 A idéia de pensar a leitura de Hegel como um mapeamento das opções e pressupostos assumidos por um determinado sistema em relação é proposta por G. Lebrun em $L$ ' antinomie et son contenu, p. 535.
} 
vista os pressupostos ali assumidos. Portanto quando Hegel reconhece que a filosofia kantiana se destina inevitavelmente a um fracasso, ele não está exigindo que se faça uma reparação pontual de aspectos discordantes de uma mesma geografia na busca de chegar a um mapa um pouco mais adequado - que seria a filosofia especulativa -, mas está indicando os impasses não superáveis daquela topologia, cujos relevos filosóficos não poderão responder adequadamente à necessidade da filosofia (Bedürfnis der Philosophie).

Quando Hegel fala em "necessidade da filosofia" - e aqui o genitivo deve ser compreendido como subjetivo e objetivo simultaneamente ${ }^{40}$ - tem em vista negar que aquilo que a filosofia tem de essencial possa ter sua origem nas particularidades de um sistema qualquer, como se ela fosse um ponto de vista peculiar. ${ }^{41}$ "A cisão (Entzweiung) é a fonte da necessidade da filosofia", escreve Hegel, indicando que somente pode haver necessidade da filosofia porque há um interesse da razão - e que portanto não pode ser particular - e que tem sua origem em uma cisão que diz respeito a uma determinada configuração histórica, uma cultura da época (Bildung des Zeitalters) na qual a vida dos homens se encontra fixada em oposições e limitações, não havendo mais nela "o poder de unificação" que lhe restituiria a sua relação viva.

"Os opostos que, outrora, tinham significado, sob a forma de espírito e matéria, alma e corpo, fé e entendimento, liberdade e necessidade, etc., em esferas mais limitadas e ainda de modos diferentes, e ligavam a si todo o peso do interesse humano, transformaram-se, com o progresso da cultura, na forma das oposições entre razão e

\footnotetext{
${ }^{40}$ A expressão "Bedürfnis der Philosophie" apresenta um genitivo que na maioria das vezes é interpretado exclusivamente enquanto um genitivo objetivo, no sentido de que a necessidade da filosofia, isto é, do pensar filosófico surgiria em decorrência de uma certa situação histórica determinada, no caso a da cisão (Entzweiung). Esse sentido do genitivo objetivo é correto, porém insuficientemente compreendido se não tomado como derivado do sentido primeiro expresso pelo genitivo subjetivo na expressão. A questão central expressa nessa necessidade da filosofia é o que a filosofia necessita para ser uma filosofia verdadeira, autêntica. "Na expressão "necessidade da filosofia' o genitivo é simultaneamente genitivo subjetivo e objetivo. Somente quando se compreende aquilo de que a filosofia necessita (bedarf), - da unidade total e absoluta -, somente então se compreende porque surge a necessidade da filosofia" Heidegger, M. Seminar in Le Thor, GA, Band 15, p. 295.

41 “Aquilo que é próprio de uma filosofia, por ser próprio, só pode pertencer à forma do sistema, não à essência da filosofia. Se algo de próprio constituísse efetivamente a essência de uma filosofia, ela não seria filosofia alguma...” Hegel, DS. p. 17.
} 
sensibilidade, inteligência e natureza e, para o conceito universal, entre subjetividade absoluta e objetividade absoluta. Suprimir tais opostos tornados fixos é o único interesse da razão" (DS, p. 21; o grifo é de nossa autoria)

A idéia de um interesse da razão, expressão já utilizada por Kant, embora em um sentido que diverge do de $\mathrm{Hegel}^{42}$, é fundamental para que se possa determinar o significado de algo como "tarefa da filosofia" assim como do diagnóstico de seu reiterado fracasso, que agora será compreendido como a impossibilidade de um determinado sistema filosófico de responder à tarefa que corresponde aos interesses supremos da razão. Sem a compreensão do que Hegel está chamando de interesse da razão, implicitamente pressuposta na expressão "Aufgabe der Philosophie", não há como se aproximar do movimento próprio da leitura hegeliana e em particular daquela feita da filosofia de Kant, para a qual, afirma Hegel, essa tarefa permanecerá uma tarefa infinita ${ }^{43}$. Isso se evidencia na seguinte passagem em que interesse da razão e diagnóstico do fracasso na realização da tarefa da filosofia estão expressos de maneira clara, e associados com o horizonte da leitura exigida:

"O exame da filosofia kantiana pôde tornar-se privilegiadamente interessante na medida em que essa filosofia do entendimento fosse elevada sobre seu próprio princípio, que ela tem na reflexão, e fosse destacada e apresentada a grande idéia da razão e [a idéia] de um sistema de filosofia que está à sua base por toda parte,

\footnotetext{
${ }^{42}$ Cf. Kant, KrV, B832. Não são poucas as passagens em que Kant faz referência ao "interesse da razão" ou à "necessidade da razão" e ao "interesse da humanidade" de acordo com a natureza da razão. No famoso trecho da primeira crítica em que Kant apresenta as três interrogações que resumem o interesse teórico e prático da razão ("o que posso saber"?; " o que devo fazer"?; " que me é permitido esperar"?), o filósofo pretende indicar como nossa razão está inevitavelmente vinculada a interesses que apenas do ponto de vista prático podem encontrar melhor sucesso, dado que a crítica recusou todo conhecimento acerca dos objetos a que a razão se dirige especulativamente conforme seus fins supremos (liberdade da vontade, imortalidade da alma e existência de Deus). "E assim, no final de contas, é sempre à razão pura, mas apenas no seu uso prático, que pertence o mérito de ligar ao nosso interesse supremo que a simples especulação pode apenas imaginar, mas não torna válido, e deste modo fazer dele não um dogma demonstrado, mas um pressuposto absolutamente necessário para os seus fins essenciais" (KrV, B846). A esse respeito, conferir também livro de Rohden, V. Interesse da razão e Liberdade. (1981)

${ }^{43}$ A noção de tarefa será uma daquelas noções centrais que receberão uma reinterpretação especulativa na filosofia de Hegel. Abordaremos essa transformação semântica no IV capítulo.
} 
como uma venerável ruína na qual o entendimento se estabeleceu" (VSPh, p 268; o grifo é de nossa autoria).

"Filosofia do entendimento", a filosofia kantiana se apresenta aos olhos de Hegel como uma ruína que apenas pôde ser a indicação dos palácios que não fora capaz de manter de pé. Aquilo que essa filosofia apresenta de racional, ali onde ela se aproxima da idéia da razão como absoluto, tal como nos juízos sintéticos a priori, na imaginação transcendental, ou no entendimento intuitivo, ela não pode compreender enquanto racional, pois seu discurso é ainda estruturado pelas categorias da reflexão próprias ao entendimento ${ }^{44}$. "Tratar a razão com entendimento" (die Vernunft mit Verstand behandeln) significa necessariamente rebaixá-la e despotencializá-la ao nível desse, abortando de antemão a idéia racional ou especulativa que em seu proceder ela não pode efetivamente exprimir. Quando Kant distingue a razão da unidade e identidade relativa da experiência possível que é o entendimento, ele acaba por elevar a razão acima dessa esfera da identidade relativa que se restringe às limitadas categorias de uma subjetividade lógica. Porém se o faz não a pode compreender nessa esfera efetivamente acima do entendimento, enquanto identidade absoluta, senão como uma idéia abstrata e não realizável. "Ela [a razão] somente foi elevada, para que a idéia especulativa que surge de maneira mais viva na imaginação, e que já foi despotencializada pelo entendimento, desça inteiramente até a identidade formal" (GuW, p. 317). Esse reiterado "pisoteamento" (Zertretung) da razão torna-se inevitável no interior dessa apreensão que previamente limita aquilo que pode ser exprimido aos contornos fixos e bem estabelecidos do modo de pensar do entendimento. E esse diagnóstico geral Hegel não restringe à filosofia de Kant, mas o associa a toda a época moderna, que, no entanto, chega à sua maior tensão nas oposições irreconciliáveis apresentadas na obra de Kant ${ }^{45}$.

\footnotetext{
44 Analisamos pormenorizadamente esses pontos em que a filosofia kantiana anuncia a idéia especulativa sem, no entanto, apreendê-la, no capítulo final de nosso trabalho.

${ }^{45}$ Cf. Horstmann, Kant und der 'Standpunkt der Sittlichkeit'. Zur Destruktion der Kantischen Philosophie durch Hegel. In: Revue Internationale de Philosophie, V. 53, n 210, 4/1999, p. 579: "Hegel pretende com sua crítica de Kant precisamente destruir um tipo de filosofia, uma tradição que encontrou sua forma exemplar na filosofia kantiana. Sob essa perspectiva, crítica de Kant é um combate contra a imagem de mundo filosófica moderna e suas fundações".
} 
O reconhecimento desse campo discursivo ${ }^{46}$, no interior do qual se nutre a filosofia de Kant, como sendo inadequado para apreender o racional e poder reconhecer nas suas próprias palavras aquilo que acerca dele ela enuncia, é a denúncia de um modo deficiente de apreensão do real ${ }^{47}$.

É nesse sentido que Hegel exigirá que se fale de duas espécies de espírito (zweierlei Geist) da filosofia kantiana para que se compreenda esse movimento interno dessa filosofia, que aos olhos de Hegel somente poderia causar "perplexidade diante de um malogro flagrante" ${ }^{48}$. Escreve Hegel:

"É do espírito da filosofia kantiana ter uma consciência sobre essa idéia suprema, mas novamente de maneira expressa exterminá-la. Nós distinguimos, portanto, duas espécies de espirito que se tornam visiveis na filosofia kantiana: um espirito da filosofia, que sempre arruína o sistema, e um espírito do sistema que caminha na direção da aniquilação das idéias da razão" (VSPh, p. 269; o grifo é de nossa autoria).

Não adianta mais lançar mão daquela distinção dicotômica entre espírito e letra, tal como fizeram Fichte e Schelling, acreditando estar a salvo da letra kantiana ao recorrer ao seu verdadeiro e fugidio espírito. Como se o espírito de uma filosofia pudesse ser absolutamente distinto do sistema que lhe deu forma!

É nesse sentido que a ambivalência que se expressa no juízo de Hegel em relação à filosofia de Kant não compartilha da mesma atitude de seus contemporâneos. $\mathrm{O}$ espírito da filosofia de Kant somente pode ser compreendido no interior da moldura geral na qual ela se expressa, de modo que recorrer a ele é permanecer de modo insuperável em seu âmbito. Isso apenas pode ser reconhecido através do "projeto clínico" presente na leitura de Hegel e que se distancia daquele feito por Schelling, já em 1797, que apenas aparentemente a ele se assemelha.

\footnotetext{
${ }^{46}$ A noção de "campo discursivo", "discurso" é discutida por Lebrun ao longo de todo o seu livro A Paciência do Conceito. Remetemos aqui, porém, em especial ao final do capítulo VI, $A$ Negação da Negação.

${ }^{47}$ Cf. Horstmann, R.P. Die Grenzen der Vernunft, p. 140.

${ }^{48}$ Lebrun, G. L' antinomie et son contenu, p. 535. trad. p. 596
} 
Quando Schelling fala de uma "doença do espírito" e da cisão da consciência de si e do mundo causada pela especulação ${ }^{49}$ que "apenas pode separar, aquilo que a realidade sempre une" 50 ele busca apresentar o que seria uma "filosofia saudável", aquela que "considera a especulação um mero meio" para a recuperação da unidade perdida. Schelling chega a caracterizar a época de Kant como "adormecida" (erschlaffte), e justifica os impasses de Kant no fato dele também ser filho de sua época. E nesse sentido, por esse diagnóstico histórico, a leitura que Schelling faz de Kant já se afasta em grande medida da perspectiva de Reinhold e Fichte ${ }^{51}$.

Todavia, a própria maneira de Schelling compreender essa "filosofia saudável” já nos indica que, embora ele reconheça os impasses apresentados pela filosofia kantiana, ele ainda não possui meios para superar seus pressupostos - ao menos à época da primeira edição das Idéias para uma Filosofia da Natureza. Hegel, que textualmente parece muito se assemelhar a Schelling, utilizando expressões praticamente idênticas no seu Differenzschrift, não fala, porém, em filosofia saudável - e isso pode servir de ajuda para compreender sua distância em relação aos demais 'pós-kantianos'. Para não associar de modo algum a tarefa da filosofia com a noção de são entendimento (gesunde Menschenverstand), Hegel não falará em filosofia saudável, e não compreenderá, ao menos a partir de 1800, a filosofia como "apenas um mal necessário", tal como Schelling não poderia deixar de fazê-lo em concordância com sua idéia da filosofia. Afastar a filosofia da idéia de "são entendimento" e "entendimento comum" é absolutamente necessário para uma filosofia que não pode ser compreendida a partir de uma referencia à "consciência natural" como seu ponto de partida. Schelling, assim como Kant e Fichte, partia da exigência de fundamentar filosoficamente os pressupostos da consciência natural. Para ele isso significava atribuir à filosofia a tarefa de esclarecer a consciência natural, seu modo de apreender a realidade (sua visão de mundo) de modo a explicar e

\footnotetext{
${ }^{49}$ Em sua Ideen zu einer Philosophie der Natur de 1797, Schelling fala dessa Geisteskrankheit como resultante da mera especulação, que é caracterizada pela separação (Trennung) daquilo que é unidade na natureza. Apenas na edição de 1803 é que o termo especulação é alterado e chamado de reflexão, indicando a muito provável influência na sua compreensão desse termo fornecida pelo Differenzschrift de Hegel (1801). Cf. Düsing, K. Spekulation und Reflexion. In: HegelStudien, Band 5, 1969, p.102.

${ }^{50}$ Schelling, Ideen zu einer Philosophie der Natur; apud R.P Horstmann, Die Grenzen der Vernunft,p. 156.

${ }^{51}$ Cf. Horstmann, R.P. Die Grenzen der Vernunft,pp. 59-60.
} 
tornar visível como ela enquanto cisão está apartada da unidade originária, devolvendo-a a condição de superar sua doença ${ }^{52}$.

A filosofia especulativa, contudo, somente pode manter uma referência à consciência natural enquanto exigência de um auto-aniquilamento e de uma autodestruição e não em vista de um esclarecimento, tal como entendem Kant, Fichte e Schelling. Como escreve Hegel: “a especulação compreende [versteht] o são entendimento, mas o são entendimento não compreende o fazer da especulação [das Tun der Spekulation]". Isso significa que não pode haver uma passagem tranqüila do senso comum ou são-entendimento para a especulação, pois aquele está preso e absorvido em seus limites e é incapaz de compreender "a sua relação com a totalidade absoluta", permanecendo essa relação inexpressa no seu íntimo - ou, para utilizar uma expressão da Fenomenologia do Espírito, essa relação se passaria como que "às suas costas" 53 . Conceber que seja possível esse esclarecimento da consciência natural revela, portanto, que implicitamente ainda se compartilha dos mesmos pressupostos daquela. Por isso que Hegel poderá escrever em relação a Kant e as filosofias da reflexão que "não há o que ver nessas filosofias senão a elevação da cultura da reflexão à condição de sistema - uma cultura do entendimento humano ordinário (gemeinen Menschenverstand)" (GuW, p. 298). O sentido desta afirmação apenas se esclarecerá no momento em que abordarmos a filosofia kantiana através da denominação que Hegel a atribui de "filosofia da reflexão".

\section{O filosofar e os sistemas filosóficos.}

"Refere-se a Kant com admiração, dizendo que ele não ensina filosofia, mas sim a filosofar; como se alguém tivesse ensinado carpintaria, mas não tivesse ensinado a fazer uma mesa, uma cadeira, uma porta, um armário, etc." (HW II, p. 559). Nesse curioso aforismo do período de Jena, Hegel dirige-se contra uma maneira ingênua, que havia se

\footnotetext{
${ }^{52}$ Cf. Horstmann, R.P. Die Grenzen der Vernunft.pp. 15-18.

${ }^{53}$ Hegel indica na Fenomenologia a distância que o "para-nós" (für-uns), a filosofia, está em relação ao saber da consciência. Enquanto essa está plenamente absorvida no seu mundo, ela não tem diante de si o movimento de passagem de sua visão de mundo para a de uma outra figura (Gestalt). Ela apenas tem um novo objeto, mas não é capaz de ver "o surgimento [Entstehung] do novo objeto", que para nós é como se ocorresse às suas costas. Cf. Hegel, PhG, HW III, p. 80.
} 
tornado moda, de compreender a filosofia kantiana - e conseqüentemente a filosofia em geral - inspirada em colocações do próprio autor da filosofia crítica ${ }^{54}$. Segundo essa visão poder-se-ia aprender uma filosofia sem com isso e para isso exercer o ato de filosofar, assim como inversamente, poder-se-ia filosofar sem com isso produzir uma verdadeira filosofia ${ }^{55}$. Essa radical separação do ato de filosofar e de seu produto, reconhece Hegel, é resultado de um entendimento de desgaste de um longo percurso de tentativas filosóficas e a insistente constatação de uma permanente controvérsia dos filósofos.

Esse é o ponto de vista que parece reinar numa época que "parece ter chegado àquela indiferença que a vida obtém após ter-se experimentado todas as formas” (DS, p. 15), segundo a expressão que Hegel utiliza no início do Differenzschrift, seu ensaio de 1801, com o qual se introduz no cenário filosófico da época, logo após sua chegada em Jena. Para um ensaio de caráter crítico $^{56}$ - a primeira publicação de Hegel e o primeiro ensaio voltado à filosofia como tal - que visa uma avaliação desses sistemas filosóficos e da filosofia de seu presente, Hegel, seguindo o modelo dos textos programáticos de Fichte e Schelling, inicia pela consideração dos objetivos, da origem, dos meios do fazer filosófico ${ }^{57}$ e da relação que a filosofia mantém com os sistemas passados - uma temática à qual Hegel sempre retornará em suas obras futuras ${ }^{58}$.

${ }^{54} \mathrm{Cf}$. Kant, a respeito do que chama de conceito escolástico de filosofia em oposição ao seu conceito cósmico: "Entre todas as ciências racionais (a priori) só é possível, por conseguinte, aprender a matemática, mas nunca a filosofia (a não ser historicamente): quanto ao que respeita à razão, apenas se pode, no máximo, aprender a filosofar. (...) Até então não se pode aprender nenhuma filosofia; pois onde está ela? Quem a possui? Por que caracteres se pode conhecer? Pode-se apenas aprender a filosofar, isto é, a exercer o talento da razão na aplicação dos seus princípios gerais em certas tentativas que se apresentam, mas sempre com a reserva do direito que a razão tem de procurar esses próprios princípios nas suas fontes e confirmá-los ou rejeitá-los". Kant, KrV, B865-866.

${ }^{55}$ Ver Lebrun, Paciência do Conceito, p. 15

${ }^{56}$ Como já abordamos na primeira parte deste capítulo, a noção de crítica filosófica deve ser aqui compreendida a partir da idéia que Hegel esboça no Jornal crítico, de revelação da Idéia da filosofia como medida para a "avaliação objetiva" de um sistema filosófico ("toda crítica é subsunção à Idéia"), e não se deve confundi-la com o termo crítica referente à filosofia de modelo kantiano. Cf. Hegel, (ÜWPhK, HW II, pp.173-187).

57 “Assim como Fichte em seu Abhandlung über den Begriff der Wissenschaftslehre, e Schelling em seu Über die Möglichkeit einer Form der Philosophie überhaupt primeiramente falaram de modo geral e introdutório sobre tarefas e métodos da filosofia, Hegel também começa perguntando o que a filosofia visa, a partir do que ela surge, o que ela pressupõe e como ela pode chegar ao seu objetivo.” Kroner, R. Von Kant bis Hegel,II, p, 143.

58 "Poucos são os temas em que Hegel se expressou de modo tão minucioso ao longo de toda sua produção como o fez acerca da pergunta do que seja a filosofia, quais seus objetos e métodos, 
Vimos na primeira parte deste capítulo como para Hegel a idéia da filosofia é uma “condição e um pressuposto" da crítica filosófica, sem a qual não haveria possibilidade alguma de exercê-la sem que toda avaliação tivesse um caráter autoritário de uma apelação a uma idéia que a filosofia avaliada não reconhece (ÜWPhK, pp. 171, 173). O que a idéia de crítica filosófica esboçada por Hegel pressupõe, portanto, é antes de tudo a necessária diferenciação entre fillosofia verdadeira (wahre Philosophie) e não-filosofia (Unphilosophie), condição de toda leitura filosófica. Sem essa distinção que tem como horizonte as noções de tarefa da filosofia (Aufgabe der Philosophie) e vida interna da filosofia (inneres Leben der Philosophie), torna-se impossível reconhecer a medida que orienta o olhar de Hegel na interpretação de um determinado sistema filosófico.

Não é um mero acaso o fato de Hegel se debruçar sobre essa distinção no interior desse seu primeiro ensaio que pretende esclarecer, num primeiro momento, qual a tarefa que a filosofia deve cumprir para que seja considerada filosofia. Esse primeiro escrito publicado será aquele em que Hegel irá situar seu próprio fazer filosófico e justificar a necessidade da filosofia no seu tempo presente. Seguiremos alguns pontos importantes dessa apresentação, em especial o debate que estabelece com Karl Leonhard Reinhold no que se refere à tarefa da filosofia em relação às filosofias do passado. Através da recusa da perspectiva defendida por Reinhold, Hegel poderá reapropriar-se da noção de sistema como critério fundamental para pensar o sucesso ou insucesso de uma filosofia. A compreensão do sentido que Hegel passa a atribuir à noção de sistema a partir de Jena é o que pode nos aproximar da medida que orienta seu olhar na interpretação da filosofia kantiana, e nos encaminhar no sentido de apreender a concepção hegeliana de especulação.

Distanciando seu ensaio daquela tendência à indiferença e ao pseudo-domínio pretendido pelas classificações rápidas que pululam na produção filosófica pósSittlichkeit'. Zur Destruktion der Kantischen Philosophie durch Hegel, p. 578. 
kantiana $^{59}$, Hegel opõe-se a uma outra postura em voga - que se evidenciará calcada nos mesmos pressupostos daquela primeira - representada pelo escrito de Reinhold acerca da "situação da filosofia no começo do século XIX" ${ }^{60}$. De acordo com a perspectiva desse autor o passado filosófico em suas diversas produções não deve ser tomado como uma multiplicidade descontínua, cuja comunicação estaria fadada às refutações e aos abandonos; aos esforços filosóficos do passado é agora atribuída a dignidade de "utilidade" para o aprofundamento dos conhecimentos do presente, a partir da idéia de um "impulso à completude do conhecimento" e de um "impulso de alargar a ciência". Caberia assim à filosofia do presente, segundo essa concepção, "levar adiante as opiniões particulares dos predecessores através de novas opiniões particulares" ${ }^{61}$, visando o seu aperfeiçoamento contínuo.

O que guia a perspectiva de Reinhold, denuncia Hegel, é uma concepção de filosofia tomada aos moldes das artes mecânicas, as quais são passiveis de perfectibilidade, e que considera "os sistemas filosóficos anteriores (...) como exercícios preliminares para as grandes cabeças” (DS, p. 35). Hegel cita uma passagem de Reinhold em que ele expressa bem essa concepção de ciência a que Hegel está chamando de "obra morta da habilidade alheia": "Só através de um tal conhecimento das tentativas que foram feitas até hoje para resolver a tarefa da filosofia, poderá por fim a tentativa dar efetivamente resultado, se é que foi concedido à humanidade alcançá-lo" ${ }^{62}$. Como se todo o passado filosófico fosse um amontoado de tentativas fracassadas na resolução da tarefa da filosofia que, no entanto, progrediriam no aperfeiçoamento técnico em vista de uma resolução ao seu termo. Essa postura que se abriga na idéia da filosofia como "amor à verdade" ou mesmo "fé na verdade" revelar-se-á, antes, como sendo tomada de um "medo da razão e da filosofia", e conservando-se numa espécie de "ante-sala" (Vorhof)

\footnotetext{
59 "Para esse gênero de indiferença, quando ela sai de si mesma por curiosidade, não há nada de mais agradável do que dar um nome a uma filosofia de tipo novo, e, como Adão exprimiu o seu domínio sobre os animais no fato de lhes ter dado um nome, exprimir o domínio sobre uma filosofia através da descoberta de um nome" Hegel, DS, p.15.

${ }^{60}$ K. L. Reinhold: Beyträge zur leichten Uebersicht des Zustandes der Philosophie beym Anfange des 19. Jahrhunderts. (1801)

${ }^{61}$ Reinhold, citado por Hegel, DS, p. 16.

${ }^{62}$ Reinhold, citado por Hegel, DS, p. 16.
} 
da filosofia, ocupada com um "filosofar provisório" que nunca de fato se efetiva, exprimindo-se apenas enquanto "incapacidade para a filosofia" 63 .

O que Hegel censura em ambas as posturas 'filosóficas', naquela em que há uma indiferença em relação ao seu passado e naquela em que se busca nesse passado meros indícios para um aperfeiçoamento técnico, é a mesma recusa - ou impossibilidade - de manter uma "participação viva" (lebendiger Anteil) com os sistemas filosóficos passados, e de reconhecer a "individualidade interessante" ${ }^{64}$ de cada figura anterior, nas quais a razão realizou ao seu modo a tarefa da filosofia: "Cada filosofia é em si mesma completa e tem, como uma autêntica obra de arte, a totalidade em si" ${ }^{65}$, afirma Hegel, enfatizando o que o afasta dessa concepção haurida do registro das artes manuais e que, de modo inevitável, permanece, em relação aos sistemas filosóficos passados, na distância indiferente do que se chama de mero conhecimento ${ }^{66}$.

A equiparação da filosofia com a obra de arte é de grande importância aqui, primeiramente pela diferenciação que se estabelece entre a "totalidade em si mesma produzida e acabada" ${ }^{67}$ de uma obra de arte ou de uma filosofia - que se manifestará para essa última através da exigência de formação de um sistema - em oposição à

\footnotetext{
${ }^{63}$ Hegel, HW II, pp. 154-5. "O amor, assim como a fé na verdade, elevou-se a uma altura tão pura e vertiginosa que ele, para que a entrada no templo seja corretamente instituída e fundamentada, edifica um átrio espantoso, no qual a verdade, para se poupar o passo, se ocupa durante muito tempo com o analisar o metodologizar e o enumerar, até que afirma, como prova da sua incapacidade para a filosofia, que os passos temerários dos outros não foram senão exercícios preparatórios, ou erros do espírito", DS, p. 18. A crítica à idéia de um "filosofar provisório", de uma "ante-sala" da filosofia e do "medo da verdade", ambas associadas ao modo de proceder da filosofia crítica, Hegel manterá até seus últimos escritos. Cf. PhG, HW III, p. 70; Enzy, HW VIII, $\S 41$, p. 114; VGPh, HW XX, p. 334.

${ }^{64}$ Hegel, DS, p. 19. Voltaremos a abordar a noção de "interessante Individualität" quando voltarmos a tratar aquilo que Hegel, na esteira de Kant, chama de "interesse da razão". Aqui indicamos apenas o contraste intencionalmente criado por Hegel entre uma "individualidade ossificada", cujo interesse para o presente se restringiria ao seu suposto fracasso no interior de uma história que ela não escreve, e a "individualidade interessante", que é reconhecida em um parentesco (Verwandtschaft) espiritual com o presente e vivificada, isto é, revelada em sua completude e vida própria pela (mesma) razão.

${ }^{65}$ Hegel, DS, p. 19. Hegel pretende com isso chamar a atenção à evidente distância que há entre a obra de arte (Kunstwerk) e a arte manual (Handwerk).

66 "Conhecimentos [Kenntnisse] encontram objetos estranhos. No saber da filosofia, que nunca foi outra coisa do que conhecimento, a totalidade do interior não se moveu e a indiferença afirmou completamente sua liberdade". Hegel, DS, p. 15.

67 “...uma totalidade em si mesma produzida e acabada, que não tem em nenhum fundamento fora de si, mas se funda em si mesma no seu início, no seu meio e no seu fim”. Hegel, DS, p. 46.
} 
referência externa de um instrumento ou qualquer artifício mecânico. Mas, além disso, e intrinsecamente ligado a esse caráter de totalidade, a semelhança com a obra de arte revela a idéia de que ambas compartilham uma tarefa comum, perspectiva que se desenvolverá até a Enciclopédia quando ambas serão, junto com a religião, situadas na esfera do espírito absoluto ${ }^{68}$. A idéia de uma tarefa comum à filosofia e à obra de arte terá um papel importante na própria concepção de crítica filosófica que Hegel desenvolve, que será pensada em analogia à crítica da arte ${ }^{69}$. Aqui queremos por ora apenas salientar como a crítica de Hegel a Reinhold visava indicar a impossibilidade que esse último apresentava de tomar um sistema filosófico em sua individualidade viva, através da participação necessária que a verdadeira filosofia requer. A exigência de uma "participação viva" é a declaração, portanto, da necessidade de que a razão que se dirige a um sistema filosófico reconheça ali seu próprio elemento e não um outro estranho que nada the diz respeito internamente, "porque na filosofia, escreve Hegel, a razão que se conhece a si mesma tem a ver somente consigo". Sem uma participação viva não há, propriamente falando, interesse da razão e toda leitura permanecerá necessariamente na distante indiferença em relação ao lido.

É portanto graças a essa auto-referência da razão e ao seu "auto-conhecimento" que se fundamenta a possibilidade de uma participação viva com a filosofia. A unidade da razão é desse modo o que garante a unidade da própria filosofia no que diz respeito à sua essência, à sua Idéia.

"Que a filosofia seja somente uma, e apenas possa ser uma, reside no fato de que a razão é somente uma. E assim como não pode haver diferentes razões, tampouco se pode colocar um muro entre a razão e seu auto-conhecer, através do qual esse poderia se tornar uma diversidade essencial de manifestação. Pois a razão, tomada de modo absoluto, e na medida em que é objeto de si mesma no auto-conhecimento, isto é, na medida em que se torna filosofia, é novamente apenas uma e a mesma e por conseqüência inteiramente igual" (ÜWPhK, p. 172; o grifo é de nossa autoria).

\footnotetext{
${ }^{68}$ Cf. Enzy, §562, pp. 371-72.

${ }^{69} \mathrm{Cf}$. Hegel, ÜWPhK, p. 171. A esse respeito conferir W. Zimmerli, Inwiefern wirkt Kritik systemkonstituirend?, In: D. Henrich und K. Düsing (Hrsg.), Hegel in Jena, (Hegel-Studien, Beiheft 20), pp. 95-96.
} 
Afirmar que a filosofia seja apenas uma não significa, contudo, negar a diversidade de sistemas filosóficos, nem ignorar o espírito do tempo em que cada filosofia surge. Ao contrário, significa reconhecer que "o fundamento da diversidade na própria filosofia não pode residir na sua essência" e que a filosofia é justamente essa razão única que, dirigindo-se a si mesma, se conhece. A Idéia da filosofia - com o sentido objetivo e subjetivo do genitivo - diz respeito tanto à Idéia que cabe à filosofia manifestar como à idéia do que é a filosofia em sua própria essência, o que especulativamente compreendido são o mesmo. Mas o sentido pleno da noção de idéia da filosofia ainda deverá permanecer indeterminado e apenas poderá ser melhor compreendido quando aprofundarmos o sentido em que a filosofia surge como possuindo uma tarefa a partir da sua relação com a vida ${ }^{70}$.

Até aqui podemos compreender em que medida essa unidade interna da filosofia, fundada na unidade da razão, exige a recusa de toda forma de apreensão que a ela se volte como um agregado de opiniões particulares, motivo pelo qual Hegel denuncia todas as formas particularizantes de filosofia, as quais se aferram a peculiaridades, e conseqüentemente se tornam incapazes de reconhecer o conteúdo verdadeiramente filosófico que ela manifesta: “Aquele que está aprisionado por uma peculiaridade [Eigentümlichkeit] nada vê nos outros senão peculiaridades", de modo que um olhar que apenas tem diante de si as opiniões particulares de um sistema, não será capaz de apreender a essência da filosofia. ${ }^{71}$ Porém,

"se o Absoluto, tal como a razão, é eternamente um e o mesmo, como de fato é, então, cada razão que se dirige e se conhece a si mesma produziu uma verdadeira filosofia e resolveu para si a tarefa que, tal como a sua solução, é a mesma para todas as épocas" (DS, p. 16).

A crítica hegeliana do início do Differenzschrift feita a toda sua época, cuja tendência Reinhold está dando voz, nos apresenta uma outra postura de se colocar em

\footnotetext{
${ }^{70}$ Conforme nosso capítulo intitulado: Reflexão e Vida.

71 “Tal como não se pode falar de melhoramentos constantes, também não se pode falar de pontos de vista próprio [eigentümlichen] em filosofia. Como poderia o racional ser uma coisa própria? Aquilo que é próprio de uma filosofia, por ser próprio, só pode pertencer à forma, não à essência da filosofia". DS, p. 16. Traduzimos o termo Eigentümlichkeit alternadamente através dos termos particularidade, propriedade e peculiaridade, conforme o contexto empregado.
} 
relação ao seu passado filosófico. Hegel apresenta a exigência de uma intimidade com os sistemas anteriores e o reconhecimento de que não há neles nada de verdadeiramente filosófico que não seja produto de uma mesma razão e de uma mesma tarefa. Portanto, se quisermos compreender o modo com que Hegel interpreta uma filosofia devemos ter sempre em vista que para uma compreensão racional da história da filosofia, isto é, "em relação à essência mais intima da filosofia, não há antecessores nem seguidores" (DS, p. 17).

Dessa forma, se a perspectiva de um progresso histórico à maneira de Reinhold lograva superar a indiferença em relação aos sistemas filosóficos passados, era apenas para despertar uma curiosidade vazia pelo passado orientada por uma suposta utilidade para o presente. Permanecendo à distância da "participação viva que a ciência exige", essa perspectiva se mantinha aprisionada a um passado filosófico em que não há verdadeiramente nenhuma "obra" da razão, nenhum sistema autêntico. Tal apreensão de uma filosofia passada, incapaz de reconhecê-la como filosofia, pois a razão ali não se reconhece a si mesma, tem diante de si apenas uma "individualidade ossificada [que] já não se atreve a viver" (DS, p. 15). Desse modo, na mesma medida em que Reinhold se esforçava em não tomar as filosofias passadas como uma "coleção de múmias" ou "opiniões mortas", acabava demonstrando que não sabia e não podia tomá-las como vivas, não reconhecendo a "originalidade viva do espírito" que habita cada filosofia particular.

O Differenzschrift terá, portanto, justamente isso por esforço: afastar-se de uma tal perspectiva doutrinaria que, pretendendo sobrepujar as filosofias passadas, não é capaz de ali reconhecer "uma força espiritual aparentada à sua", uma crítica que, todavia, tornou-se comum endereçar ao próprio Hegel ${ }^{72}$. Essa perspectiva não pretende ignorar as particularidades de um sistema de filosofia; ao contrário, impõe a tarefa de compreendêlas a partir de uma outra perspectiva:

"O verdadeiramente próprio [das wahre Eigentümliche] de uma filosofia, escreve Hegel, é a individualidade interessante, na qual a razão organizou para si mesma uma figura, com os materiais de uma época particular; aí, a razão especulativa particular encontra o

${ }^{72}$ Cf. Lebrun, A Paciência do Conceito, p. 220 
espírito do seu espírito, a carne da sua carne, intui-se a si nela como uma e mesma essência viva e como um outro" (DS, p. 19).

Vemos desse modo que a essa crítica à indiferença no tratamento dos sistemas filosóficos subjaz a reivindicação de uma relação com a história da filosofia que tenha seu olhar voltado ao espírito vivo que está presente em toda verdadeira filosofia. Essa noção de wahre Philosophie, que está intimamente vinculada à idéia de que à filosofia cabe uma tarefa, é a exigência do olhar que pretende apreender e reconhecer o que há de verdadeiro em um sistema filosófico. O Differenzschrift anuncia portanto sua empreitada ao pretender, antes de qualquer coisa, indicar a necessária diferença de olhar a partir da qual um sistema de filosofia pode se tornar interessante para uma razão que ali reconheça a si mesma. Por conseguinte, não podemos compreender a magnitude da leitura que Hegel faz da filosofia de Kant se não investigarmos previamente a altura de seu olhar.

Voltemos então à crítica que Hegel endereçava a Reinhold na busca de reconhecer o que lhe passava despercebido devido a essa deficiência de seu olhar. Já podemos apenas indicar o seguinte: não se pode apreender a idéia da filosofia sem $o$ reconhecimento da "autêntica necessidade filosófica" que assume uma figura própria a cada época, mas que em sua essência é uma e a mesma.

Conseqüência inevitável da "visão da situação da filosofia" apresentada por Reinhold era a sua confusão (Verwirrung) - compartilhada pelo grande público - acerca dos sistemas filosóficos de Fichte e de Schelling, segundo a qual não haveria diferença essencial entre ambos os sistemas. E se no interior dessa aparente semelhança que as nivelava numa suposta identidade filosófica alguma mínima diferença pudesse ser notada, percebia-se "mais o esforço de contornar essa distinção, ou em ocultá-la, do que uma clareza de consciência acerca dela.” (DS, p. 9). É a essa confusão que Hegel atribui a “ocasião externa” desse seu primeiro ensaio a ser publicado. Por “ocasião externa” Hegel refere-se precisamente a essa tendência da época, da qual a perspectiva de Reinhold será um fiel representante, que é incapaz de reparar na diferença entre ambos os sistemas de Fichte e Schelling. Essa miopia que Hegel quer denunciar é todavia mais profunda do que pode parecer à primeira vista - tal como fora visto pela grande comunidade filosófica da época. Para poder reconhecer essa diferença é necessário uma visão mais penetrante do que aquela que pretende realizar uma classificação escolar de ambos os sistemas. E isso 
se deve ao fato de que a diferença que Hegel tem em vista não é apenas exterior a esses sistemas, mas habita o interior de $\operatorname{ambos}^{73}$ enquanto tendências conflituosas e cuja manifestação é mais nítida em Fichte:

"Ter de distinguir estes dois lados do sistema fichteano - um lado segundo o qual ele expõe de modo puro o conceito da razão e da especulação, portanto, torna a filosofia possível, e outro lado, segundo o qual ele põe como um só a razão e a consciência pura e eleva a princípio a razão concebida numa figura finita -, tem de se mostrar como necessidade interna da própria coisa" (DS, p.11).

É a essa dupla diferença a que Hegel faz referência com a primeira palavra desse seu ensaio que terá por incumbência explicitar e esclarecer onde reside a "Differenz", de modo que ambos os sistemas possam ser apreendidos enquanto filosofias autênticas em sua originalidade viva - algo que a assimilação das duas impossibilitava, além de revelar a incompreensão de cada uma delas em particular.

Assim sendo, a motivação do Differenzschrift não encontra sua justificativa apenas nessa tendência da época em desconhecê-la, como se tratasse de uma mera correção de uma interpretação inadequada. $\mathrm{O}$ intuito de Hegel era bem mais profundo: $a$ tendência da época em não reparar nas diferenças entre estas filosofias era a expressão de uma tensão anterior a ela, da qual ela era conseqüencia necessária, e que reside no

\footnotetext{
${ }^{73}$ Estamos de acordo com a compreensão de que, apesar da proximidade espiritual expressa pelo próprio Hegel entre sua filosofia e a de Schelling nesse período, no Differenzschrifft Hegel já apresenta vários aspectos que o distanciam da filosofia de Schelling. T. Haering é da mesma opinião, e escreve: "Não se deixa desconhecer que a diferença que Hegel encontrou entre Fichte e Schelling, entendida em suas conseqüências, - do modo que Hegel tinha de compreender conforme seu desenvolvimento anterior que nos é conhecido - no fundo teria necessariamente que ir além do Schelling real e teria que fazer necessária uma síntese (dialética) de ambos em Hegel. Contudo, o ponto de vista de Schelling aqui (meio inconscientemente) está principalmente já no sentido que Hegel mesmo retrata. Bem possível que Hegel então ainda contemplava o ponto de vista de Schelling mais com os seus próprios olhos. Nós sabemos, porém, quão pouco ele, de modo geral, o conhecia pormenorizadamente até aquele momento. De fato, Hegel já estava então para além tanto de Schelling quanto de Fichte." Haering, Hegel. Sein Werk und sein Wollen, I, p.608. (O grifo é de nossa autoria). Cf. também, L. Siep, Der Weg der Phänomenologie des Geistes, pp. 14, 32. E K. Düsing, Idealistische Substanzmetaphysik. Probleme der System Entwiclung bei Schelling und Hegel in Jena, pp. 30-31. M. Baum, ao contrário, não é dessa opinião e reconhece o Differenzschrift estando "à serviço da filosofia da natureza tornada filosofia da identidade de Schelling”. Die Entstehung der Hegelschen Dialektik, p.77.
} 
cerne desses sistemas ${ }^{74}$. Não se trata, portanto, de um esforço didático de interpretação filosófica, que visaria apenas uma retificação de um aspecto ignorado pelos seus contemporâneos. Hegel responde antes a uma "necessidade interna da própria coisa" (DS, p. 12), uma "necessidade da filosofia" que está sendo obliterada. Nessa exigência da filosofia Hegel reconhece a "ocasião interna" de seu ensaio.

Com o Differenzschrift Hegel se insere, portanto, na discussão filosófica não somente porque agora teria a filosofia como seu objeto - como se costuma afirmar -, mas porque responderia agora a uma necessidade da própria filosofia, tarefa que demanda um simultâneo diagnóstico da cegueira da época. A idéia de diagnóstico deve aqui ser bem entendida. O programa de reconhecer e revelar o espírito vivo de uma filosofia, respondendo a uma necessidade da filosofia, deve ser internamente vinculado à tarefa de reconhecer aquilo que tende a impedir e sufocar o seu aparecimento. Esse "projeto clínico", termo de G. Lebrun, inscrito no coração da filosofia de Hegel é a exigência de que se revelem os pressupostos secretos que incessantemente sabotam aquilo que é do interesse da razão. Diagnosticar é assim o procedimento de discernir o lugar a partir de onde algo é enunciado de modo a que se possa, a partir de um descolamento, falar de um outro lugar, isto é, "submeter a uma nova iluminação o discurso" ${ }^{75}$. Como veremos, esta será a chave da leitura especulativa que Hegel faz da filosofia kantiana, através da qual ele pretende revelar a ambigüidade ("os dois pontos de vista") na raiz da reflexão filosófica da Kant.

\footnotetext{
${ }^{74}$ Essa será uma prerrogativa da maneira que Hegel concebe a filosofia. Apesar de Schelling fazer referência à situação histórica (Cf. Ideen zu einer Philosophie der Natur), o "ponto de vista histórico-filosófico" presente no "modo com que Hegel filosofa sobre a filosofia" distancia-se claramente de seus predecessores. Cf. Kroner, Von Kant bis Hegel, II, p.145-46. Cf. também Horstmann, Die Grenzen der Vernunft p. 59-60).

${ }^{75}$ Lebrun, G. A paciência do conceito, p. 219. Lebrun tem uma interpretação ainda mais radical, com a qual não podemos concordar plenamente. Ao invés de reconhecer o campo discursivo a partir de onde uma filosofia pode proferir algo, e em seguida transferir-se para um outro lugar, ele chega a afirmar que o resultado desse diagnóstico próprio à leitura hegeliana não é seguido de um estabelecimento de um novo campo discursivo, mas sim de um "recolhimento da linguagem sobre si mesma" que não tem diante de si uma nova paisagem: "Se o Saber, com efeito, nos expatria, não é ao nos transferir para outro lugar, mas aí nos fazer perder o gosto por toda paisagem", Idem, p. 404-05.
} 
Como já indicamos acima, o nome de Reinhold não é escolhido para ser o portavoz dessa confusão dos sistemas sem um motivo preciso. Sem reconhecer o lugar de Reinhold enquanto leitor de Kant, estaríamos necessariamente diminuindo a amplitude da crítica de Hegel. Ela ganha ao contrário maior clareza e densidade na medida em que essa tendência de época é associada ao papel particular e decisivo que Reinhold teve na filosofia pós-kantiana. Levando isso em conta poderemos nos aproximar da outra palavra capital do título do Differenzschrift, o termo "sistema", o qual, embora não apareça expresso no título abreviado da obra, orienta todo o escrito, como faz questão de indicar Jaeschke em seu Hegel Handbuch ${ }^{76}$. A idéia de sistema, que Hegel a partir de Jena cada vez mais desenvolverá, será pedra de toque para a avaliação das diversas filosofias.

Reinhold, o renomado intérprete e difusor da filosofia kantiana que fora reconhecido como tal pelo próprio Kant ${ }^{77}$ após a publicação de suas Briefen über die Kantischen Philosophie, ficou conhecido pelo seu "espírito sistemático" tão exaltado por Fichte $^{78}$, e pela correspondente exigência de esclarecer os pontos obscuros e as equivocidades da filosofia kantiana buscando as premissas tácitas que estariam na base do edifício crítico $^{79}$. Muito embora a exigência de sistematicidade dirigida à teoria apresentada na primeira Crítica não buscasse colocar em questão o lugar de Kant como "o fundador e renovador da filosofia científica", ela necessariamente vinculava o empreendimento crítico a essa tarefa de sistematização que a própria crítica reivindicaria, mas não teria podido realizar completamente, além de, através dessa inflexão, reorganizar a paisagem dos possíveis sistemas filosóficos no interior dessa relação de fronteiras com

\footnotetext{
${ }^{76}$ Jaeschke, W. Hegel-Handbuch, p. 110.

${ }^{77}$ Cf.Kant. Über den Gebrauch theologischer Prinzipien in der Philosophie, UGTP, VIII, p. 184.

78 "O autor está profundamente convencido de que, depois do espírito genial de Kant, nenhum presente mais alto poderia ter sido feito à filosofia do que pelo espírito sistemático de Reinhold...”. Fichte, Über den Begriff der Wissenschaftslehre, Vorrede, GA I,2, p. 110. A alta consideração de Fichte por Reinhold transparece em suas cartas a ele destinadas, como se pode notar, nas cartas de mesmo ano de seu escrito programático. (Cf. Fichte Briefe an Reinhold 15.01.1794 01.03.1794). Ver também, Fichte, Aenesidemus-Rezension, GA I,2, p. 62.

${ }^{79} \mathrm{Cf}$. Reinhold Versuch einer neuen Theorie des menschlichen Vermögen, p. 67. "Although Kant does begin the Critique of Pure Reason with a set of terms, he provides no explicit justification for his terminology. (...) Starting from this terminology, Kant nonetheless omits any systematic introduction to it. In the Transcendental Deduction, he adds the theory of self-consciousness and of combination. Despite his claim that self-consciousness is the highest point of transcendental philosophy, to which all knowledge must conform, he never starts from it in order to develop a definition of what sensibility and conceptuality are. Reinhold wanted to fill this lacuna" Henrich, D. Between Kant and Hegel, p. 124.
} 
o sistema de Kant. Esse espírito sistemático criava assim através dessa exigência a “distinção entre os resultados já postos pelo próprio Kant no quadro de sua teoria crítica e as premissas da filosofia crítica não feitas de modo suficientemente claro por Kant" ${ }^{80}$. Isso fez com que se tornasse uma característica peculiar dos filósofos do período entre Kant e Hegel a postura ambivalente frente aos feitos kantianos ${ }^{81}$, embora, como já apontamos na primeira parte deste capítulo, essa ambivalência tenha um significado distinto em Hegel ${ }^{82}$.

Essa maneira de se posicionar em relação à filosofia de Kant desenvolvida por Reinhold ganha expressão, talvez a mais ilustrativa, na filosofia de Fichte com a curiosa fórmula "Kant bem sabia aquilo que não disse", escrita em uma nota de sua Wissenschaftslehre de 1794 que visava orientar o leitor para a correta compreensão de sua Doutrina da Ciência - que nada mais seria do que o estabelecimento do fundamento não explicitado por Kant da sua filosofia, como haveria de se convencer aquele que desejasse se "familiarizar com o espirito de sua filosofia" ${ }^{83}$. Com Fichte, portanto, firmava-se esse posicionamento de Reinhold em relação à filosofia de Kant que seria determinante para todo idealismo alemão e que R-P. Horstmann resume do seguinte modo: "Para a consolidação da filosofia kantiana é necessário mais do que o próprio Kant tem a oferecer e quer oferecer" ${ }^{84}$. Consolidar a filosofia kantiana era entendido desde Reinhold como fornecer-lhe a sistematicidade da qual ela carecia. E Hegel se mostrará até certo ponto, é preciso acrescentar - herdeiro dessa tradição pós-kantiana, como ele faz

\footnotetext{
${ }^{80}$ Cf. Horstmann, Die Grenzen der Vernunft, p. 49.

${ }^{81}$ Horstmann, op. cit, p. 26.

${ }^{82}$ Como pretendemos apresentar ao longo deste trabalho, a posição de Hegel é também caracterizada por uma ambivalência em relação à filosofia de Kant, todavia, diferentemente de Fichte e Schelling, Hegel julga ser inevitável a impossibilidade de realização do conteúdo verdadeiramente filosófico daquela filosofia a partir da colocação inicial do problema tal como é posto no interior da perspectiva kantiana e dos seus pressupostos. Sobre essa perspectiva hegeliana escreve R. P. Horstmann: "Ele em nenhum momento deixou de insistir no fato de que Kant já errou no início, e que não haveria nenhuma ponte entre aquilo que ela já cedo chama de 'a verdadeira filosofia' e um pensamento submetido às pressuposições kantianas, de modo que seguir Kant significaria abandonar e perder a idéia da filosofia. Nesse sentido, para Hegel sempre fora evidente que o filosofar verdadeiro apenas pode surgir numa figura que seja inteiramente outra do que aquela em que se forma o pensamento kantiano ou o pensamento à la Kant". Kant und der 'Standpunkt der Sittlichkeit'. Zur Destruktion der Kantischen Philosophie durch Hegel, p. 568.

${ }_{83}^{83}$ Fichte, Grundlage der Wissenschaftslehre, GA I,2, p. 335.

${ }^{84}$ Horstmann, R.P. op. cit. p. 48.
} 
questão de indicar no segundo parágrafo de seu ensaio Differenzschrift, em que reconhece Hegel o mérito de Fichte escrevendo:

“A filosofia kantiana precisou que o seu espírito fosse separado da sua letra e que o puro princípio especulativo fosse destacado do restante, que pertencia à reflexão raciocinante [räsonierende Reflexion] ou podia ser utilizado a favor dela. No princípio da dedução das categorias, esta filosofia é autêntico idealismo, e este princípio é o que Fichte extraiu de forma pura e rigorosa e a que chamou espírito da filosofia de Kant” (DS, p. 9) ${ }^{85}$

Se Hegel parece compartilhar desse recurso comum de leitura à sua época, sua postura, no entanto, apresenta a idéia de sistema a partir de uma perspectiva mais profunda, e para qual não há sentido em se buscar a consolidação do sistema de Kant. A noção de sistema, à qual Hegel será levado a partir de suas investigações de juventude, será considerada como a própria expressão da tensão entre o princípio especulativo de uma filosofia e a sua manifestação em um todo orgânico, em um sistema. Se o interesse da razão é a supressão das contraposições tornadas fixas, a partir de onde surge a necessidade da filosofia, sua tarefa será a de expor essa identidade na forma de um sistema, isto é, numa totalidade objetiva. O que, porém, constitui o núcleo da tensão presente nesta tarefa é, como veremos mais adiante, que a manifestação do absoluto, identidade dos contrapostos, assume, ela mesma, a expressão da não-identidade: "a manifestação não é identidade" (DS, p. 47). Nesse sentido a realização da tarefa da filosofia deverá poder conciliar simultaneamente a manifestação e a identidade.

Esta é, pois, a medida que deve orientar a avaliação de um sistema filosófico, isto é, a possibilidade de um sistema suportar o conteúdo especulativo que, enquanto é filosofia, exprime.

\footnotetext{
${ }^{85}$ Schelling também lança mão desse artifício (distinção entre o Espírito e a Letra, assim como das Premissas e dos Resultados), como ele encontramos em Vom ich als Princip der Philosophie..., SW I, p. 77. Ou também em carta a Hegel (06.01.1795): “A filosofia ainda não chegou ao fim. Kant forneceu os resultados; ainda faltam as premissas. E quem pode compreender os resultados sem as premissas. Um Kant é certo...". Briefe von und an Hegel. (06.01.1795), Band I, p. 14. Ver também Schelling, Cartas sobre o Dogmatismo e Criticismo, (1973), trad. p. 188.
} 
"É possível que uma autêntica especulação não se exprima perfeitamente no seu sistema, ou que a filosofia do sistema e o próprio sistema não coincidam, que um sistema exprima, da forma mais determinada, a tendência para aniquilar os contrapostos, e não consiga alcançar a identidade acabada. A diferença entre estas duas considerações torna-se importante particularmente na avaliação dos sistemas filosóficos" (DS, p. 47).

O que Hegel está nos apresentando é, antes de tudo, um método de leitura e avaliação de um sistema filosófico. Uma vez que todo sistema filosófico enuncia a seu modo a idéia da filosofia que o constitui, e que "a história da filosofia só tem valor e interesse quando se detém nesse ponto de vista" (DS, p. 47), a leitura filosófica, ou a avaliação de um sistema filosófico tem a tarefa de indicar o descompasso existente entre "a autêntica especulação" e sua expressão em um sistema. Um sistema filosófico é, portanto, ele mesmo, a expressão que um princípio especulativo (filosofia) pôde assumir em uma determinada configuração histórica, isto é, na medida em que corresponde a "uma necessidade mais universal da filosofia". Reconhecer uma distância entre filosofia e sistema significa, então, "discernir no coração de um mesmo sistema duas perspectivas diferentes, uma autêntica e a outra inautêntica" ${ }^{86}$, perspectiva fundamental da "hermenêutica" hegeliana, sem a compreensão da qual não poderíamos pensar corretamente o sentido de Hegel leitor de Kant.

A problemática em relação à possibilidade de um sistema realizar ou não a tarefa da filosofia é aquela que orientará inteiramente a leitura que Hegel faz da filosofia de Kant no período inicial de Jena. E, diferentemente de Reinhold, Hegel não afirmará ser a falta de sistematicidade da obra kantiana que constitui seu ponto fraco, mas antes a impossibilidade da verdadeira filosofia que ali se apresenta assumir a forma do sistema. Pois reconhecer a verdadeira filosofia na base de um sistema filosófico é reconhecer o próprio sistema como sendo a configuração de uma tensão. Essa é a razão, afirma Hegel, pela qual Reinhold não pôde diferenciar a filosofia de Schelling daquela de Fichte: Reinhold "não reparou na diferença entre ambas como sistema, e, além disso, não as tomou como filosofias" (DS, p. 116) ${ }^{87}$.

\footnotetext{
${ }^{86}$ Hypolitte, J, La critique hegelienne de la reflexion kantienne, p. 87.

${ }^{87} \mathrm{O}$ grifo é de nossa autoria
} 
Uma vez que a preocupação sistemática de Reinhold era a de fundamentar analiticamente o conhecimento, e a partir do reconhecimento da equivocidade da filosofia kantiana indicar-lhe suas obscuras premissas, a autêntica especulação, seu verdadeiro lado sintético não podia ser por ele reconhecido.

"Se, de acordo com Reinhold, a ocupação mais essencial da filosofia, seu tema e seu princípio é a fundamentação da realidade do conhecimento pela análise, isto é através da separação, certamente então a especulação, cuja tarefa suprema é suprimir a separação na identidade de sujeito e objeto, não tem qualquer significado, e o lado mais essencial de um sistema filosófico, que é ser especulação, não pode assim ser tomado em consideração" (DS, p. 119).

Somente àquele que tem o olhar voltado ao princípio especulativo, à idéia da filosofia, é que pode não se espantar que "o filosofar deva ser introduzido na filosofia" (DS, p. 120), isto é, que ela deixe de ser a opinião morta para ser reconhecida em seu espírito vivo. Devemos pois seguir essa perspectiva própria ao modo com que Hegel lê a filosofia de Kant. Sua leitura caminha, como pretendemos indicar nesse trabalho, no sentido de reconhecer a filosofia, a especulação, que se recusa a se restringir à forma de um sistema da reflexão.

Voltemos agora à pergunta acerca da arte de ler hegeliana. Como buscamos mostrar, a própria idéia de crítica filosófica tal como Hegel a compreende depende de uma aproximação no sentido de poder revelar o espírito vivo que habita um determinado sistema filosófico. Nesse sentido, aproximar-se de uma filosofia exige que a razão possa reconhecer a si mesma na filosofia, como que intimamente habitando a figura determinada de um sistema de filosofia. "Externo, seu método também quer ser interno" ${ }^{88}$, escreve Philonenko, indicando a constante tensão presente no modo de ler hegeliano, que pode a partir de um outro lugar habitar na imanência de uma dada filosofia. Quando falamos em leitura imanente, não temos portanto em vista uma leitura que esteja completamente absorvida na forma particular de pensar de uma determinada filosofia.

${ }^{88}$ Philonenko A. Introduction à Foi et Savoir. In: Hegel, Foi et Savoir, p. 13. 
Imanência não pode significar permanecer no interior de um pensamento no sentido de não poder dizê-lo em seus limites, isto é, não poder reconhecer o que seus contornos não permitem apreender. Hegel, nesse sentido, evidentemente não teria uma leitura imanente, pois como tentamos mostrar, busca desde o início reconhecer e desenvolver aquilo que não pôde e nem poderia ser feito no interior de um modo determinado de pensar, no modo kantiano. Se, todavia, por imanência nós compreendermos, ao contrário, o esforço permanente de, jamais abandonando o suporte do texto, mapear e explicitar o que há de especulativo e, portanto interessante em uma filosofia - certamente podemos afirmar a imanência de sua leitura.

Não são poucos os momentos em que Hegel claramente aponta para uma filtragem dos aspectos da filosofia kantiana que "são de interesse seguir" (GuW, p.328), revelando o seu esforço de exprimir o que ali não pode ganhar expressão. Dessa forma, Hegel não pretende indicar os aspectos especulativos que Kant teria expresso, porém não suficientemente desenvolvido. Aquilo que havia de especulativo no que Kant apresentou não podia ser compreendido a partir da orientação geral do pensar kantiano, como se apenas uma outra semântica pudesse compreender o sentido especulativo daquelas palavras.

O que Hegel propõe é uma leitura interessada, isto é, orientada por um interesse que não é o de Hegel ou de qualquer filosofia particular - como se existisse efetivamente uma?! - mas o interesse da razão que é uma e a mesma e que pode assim encontrar em outra filosofia "o espírito do seu espírito, a carne de sua carne" (DS, p. 19). Esse é o sentido da imanência que orienta Hegel na leitura de Kant. Chamar de dogmática toda leitura que não esteja absorvida na estrutura interna de um determinado pensamento é, para Hegel, impossibilitar que a filosofia possa ser, efetivamente, filosofia. 


\section{CAPÍTULO II}

\section{FILOSOFIAS DA REFLEXÃO}

"Como um vento uivante do norte, o
presente perpassa as flores de nosso espírito,
secando-as ao nascerem" (Hölderlin,
Hyperion, p. 20)

"Oh, o homem quando sonha é um deus, mas quando reflete é um mendigo"

(Hölderlin, Hyperion, p. 14)

\section{A razão tratada com entendimento}

"Razão despotencializada" (herabpotenzierte Vernunft), "pisoteamento da razão" (Zertretung der Vernunft), "razão envergonhada" ${ }^{89}$; não são poucas as expressões que Hegel utiliza para indicar a situação da razão resultante da filosofia kantiana. Para uma filosofia que pretendia antes de tudo uma elevação da razão - afinal esse era o suposto sentido da autodeterminação e circunscrição de seu terreno proposto pela Aufklärung -, nada poderia soar como maior fracasso, aos olhos de Hegel. E não há como o próprio autor da Crítica da Razão Pura deixar de reconhecer, ao lado dos méritos de sua filosofia, a posição humilhante a que se "elevaria” a razão:

"É humilhante [demütigend] para a razão humana, escreve Kant, que, no seu uso puro, não chegue à conclusão alguma e necessite mesmo de uma disciplina para reprimir os excessos e impedir as ilusões que daí lhe resultam" (Kant, KrV, B823).

Conseqüência desse tribunal a que a razão é submetida para “determinar e julgar os [seus] direitos" (KrV, B779), resta-lhe apenas, ao final de seu exame, a comedida

${ }^{89}$ Hegel, DS, p.12; GuW, p. 321 e p. 288 , respectivamente. 
satisfação de ser ela mesma a autora de sua censura e disciplina, além do alívio obtido na recusa de toda pretensão transcendente que lhe imputam através de autoridades terceiras ou de argumentos sofísticos. De positivo, porém, em nada pode alargar seu conhecimento e todos os seus anseios especulativos permanecem a ela interditos em seu silêncio sobriamente assumido contra o erro ${ }^{90}$. Esse seu resultado, que representa um dos aspectos maiores da chamada Kantkrise ${ }^{91}$, é o que Hegel entenderá como corolário inevitável para todas as filosofias da reflexão, sendo a kantiana a sua representante principal e dona de seu espírito.

Orientadas por um "princípio da subjetividade" (Prinzip der Subjektivität) nem sempre confesso ${ }^{92}$, essas filosofias acabam inexoravelmente assumindo como seu "ponto supremo" aquilo que uma vez já indicara a própria "morte da filosofia", a saber, que "a razão deveria renunciar ao seu ser no absoluto" (GuW, p. 289). Para essa filosofia “esclarecida", que para além de seu impulso infinito, reconhece humildemente a finitude de seu saber, o absoluto $^{93}$ tem de ser tomado sempre como Jenseits, como um além

\footnotetext{
90 "Onde nem a intuição empírica nem a intuição pura mantém a razão num caminho bem visível, a saber, no seu uso transcendental, em que procede por simples conceitos, torna-se tão necessária uma disciplina, que reprima a sua tendência a estender-se para além dos estreitos limites da experiência possível e a mantenha longe de todos os excessos e de todo erro, de modo que toda a filosofia da razão pura não tem outro objetivo a não ser essa utilidade negativa", Kant, KrV B739 (o grifo é de nossa autoria). Sobre o caráter eminentemente negativo da crítica, ver também $\mathrm{KrV}$, B XXIVe XXV.

${ }^{91}$ Cf. Pöggeler, O. Hegel und die Anfänge der Nihilismus-Diskussion, pp. 338-39. Pöggeler faz referência à "perturbação" que a filosofia crítica havia provocado não apenas no círculo restrito da filosofia, mas em toda uma geração de "pensadores e poetas". Como exemplo, o autor cita uma carta do escritor Heinrich von Kleist sobre esse impacto da filosofia kantiana na sua crença de conhecer e, apreender pela razão, um sentido último da vida : "O pensamento de que nós aqui em baixo nada, absolutamente nada sabemos, de que isso que aqui chamamos verdade tem outro nome depois da morte, e de que, conseqüentemente, o esforço de se angariar uma propriedade que nos acompanhe até a cova é totalmente infrutífero e à toa - esse pensamento me fez tremer no santuário de minha alma".

92 No caso de Kant, porém, segundo Hegel, o princípio da subjetividade é "abertamente confessado", e sua essência de "idealismo crítico" manifestamente assumida. Cf. Hegel, GuW, p.300.

${ }_{93}$ Abordaremos mais adiante a complexa noção de Absoluto na filosofia de Hegel no período inicial de Jena. Por ora é importante indicar que embora esse termo possua uma tradição que remonte a Nicolau de Cusa, Giordano Bruno e Leibniz, e que Kant não tenha quase feito uso dele nesse formato (das Absolute), a filosofia crítica utiliza, em contrapartida, em inúmeras passagens, o adjetivo "absolut" e tem constantemente em seu horizonte os termos "incondicionado" (Unbedingten) e "totalidade incondicionada" (unbedingte Totalität) que, embora não se identifiquem plenamente com o termo tal como é empregado por Hegel (e por Schelling), compartilham alguns aspectos em comum. A esse respeito sugiro: Jäschke, W. Hegel Handbuch,
} 
incognoscível e contraposto à razão, do qual ela exige a sua exclusão e com o qual ela mantém uma relação meramente negativa $(\mathrm{GuW}$, p. 289). Diante do "perigo do entendimento" (Gefahr des Verstandes) e de sua ameaça de apreender como "coisa" aquilo que recusa qualquer objetificação, a razão, nessa sua renúncia (Verzicht), acabava por se aparentar ao seu algoz, limitando-se à sua esfera e negligenciando aquilo a que se destina seu saber - enfim, a morte da filosofia. Pois, como afirma Hegel,

“o desprezo pela razão não se mostra de forma mais forte pelo fato de ela ser livremente desprezada e injuriada, mas sim pelo fato da limitação [Beschränktheit] se gabar do seu domínio sobre a filosofia e da sua amizade por ela" (DS, p. 24).

Esse é, pois, o reinado do entendimento, essa "força de limitar" (Kraft des Beschränkens), que instaura um abismo entre o homem e o absoluto, e fornece a "tudo o que para o homem é valioso e sagrado" a sua forma limitada, podendo-se "encontrar aí [na sua esfera] a totalidade das limitações, só que não o próprio absoluto" (DS, p. 20). O rebaixamento da razão aos limites do entendimento; o caráter formal de todo o saber; a fixação da subjetividade agora tornada absoluta; e também a irredutível contraposição entre o absoluto e a finitude da razão - estas são as principais manifestações que estão à base deste diagnóstico que Hegel realiza de todas as filosofias da reflexão (Reflexionsphilosophie) à época de Jena.

A denominação "Filosofia da reflexão", que aparece pela primeira vez no título de Glauben und Wissen (1802) - um ensaio que Hegel escreve para o Jornal Crítico de Filosofia co-editado por Schelling -, surge como uma designação que pretende abranger um modo particular de filosofia reinante em sua época. Seus maiores expoentes: Kant, Fichte e Jacobi - que são aqui alinhados como herdeiros e aperfeiçoadores tanto da negatividade, quanto das oposições e limitações inscritas no coração do iluminismo ${ }^{94}$ são os nomes principais dessa figura filosófica que é antes de tudo a "expressão de uma

pp. 110-112. Ver também Göbel, W. Reflektierende und absolute Vernunft, Die Aufgabe der Philosophie und ihre Lösung in Kants Vernunftkritiken und Hegels Differenzschrift, pp. 120-143.

${ }^{94}$ Como veremos mais adiante, o que é comum a esses representantes da Filosofia da Reflexão, afirmará Hegel, será a apreensão da negatividade da Aufklärung, de seu "procedimento negativo" através do qual se libertam de um agir presunçoso que a antecedia, para, no entanto, reencontrarse ao final limitada na empiria e finitude. Cf. Hegel, GuW, pp. 288-89. 
situação histórica" particular ${ }^{95}$ que em seus caracteres essenciais está em germe desde o nascimento da modernidade. O título completo da obra se pretende um resumo do tema ali desenvolvido: Fé e Saber ou a Filosofia da Reflexão da Subjetividade na completude de suas formas enquanto Filosofias Kantiana, Jacobiana e Fichteana. Através da investigação dos impasses inscritos nessas filosofias, Hegel as reúne sob a rubrica do espirito kantiano ${ }^{96} \mathrm{e}$ do caráter reflexivo e formal que as domina para mostrar suas irresolutas contradições internas, em especial aquela entre fé e saber, que toda a elevada cultura da época pretendeu ter suprimido, libertando a filosofia da condição de "criada da fé" (Magd des Glaubens) (GuW, p. 287).

Ao falar em uma cultura da época, Hegel tem aqui em vista as mais diversas dimensões (intelectual, estética, moral e religiosa) de uma certa maneira de pensar, característica do Protestantismo, que o Iluminismo parece abarcar como categoria maior, e que se caracteriza por um movimento geral em direção à interioridade do espirito ${ }^{97}$. Como escreve A. Philonenko, "os tesouros, próprios à intuição externa, pinturas, estatuas, arquitetura, jóias que a igreja católica da alta idade-média havia acumulado devem aparecer como vestígios, e o protestantismo foi um imenso movimento de retração à interioridade da consciência desejosa de ser para ela mesma essencialmente uma bela alma" ${ }^{98}$. A beatitude moral e a grandiosidade dessa bela alma dependerão, dessa maneira, de reflexões internas e meditações que, apartadas do mundo sensível, poderão, supostamente, salvaguardar a pureza da bela subjetividade.

O que a crítica hegeliana irá desde o início ressaltar nessa postura protestante é a não independência que essa interioridade manterá em relação à exterioridade da qual, em

\footnotetext{
${ }^{95}$ Horstmann, R.P. Die Grenzen der Vernunft..., p. 64. Cf. Também. Düsing, K. Spekulation und Reflexion, pp. 105-106; Jaeschke, op. cit. p. 136-139. Ver também Habermas, J. O Discurso Filosófico da Modernidade. pp. 35-63.

${ }^{96}$ Por espírito kantiano não se deve entender aqui simplesmente aquele que se opõe à letra, conforme a distinção corrente no pós-kantismo, mas aquele "espírito sem-espírito" (der geistlose Geist) que nela se revela e que dela não consegue se afastar. Esse espírito kantiano é pois aquele que predomina nas filosofias da reflexão. Cf Hegel, VSPh, p. 268.

${ }^{97}$ Hegel irá identificar essa maneira de pensar do protestantismo (o abismo que ele instaura entre a "bela subjetividade" e a exterioridade; o princípio de subjetividade que nega e destitui o valor do mundo sensível em nome de uma infinitude interna, etc.) como "princípio do norte" (GuW, p. 289), estabelecendo uma indicação geográfica e até "climática" (DS, p. 22) para essas cisões da época moderna. Sobre a relação entre as filosofias da reflexão e o protestantismo, cf. Philonenko A. Introduction à Foi et Savoir. In: Foi et Savoir. Ver também Jäschke, W. op. cit., pp. 136-144.

${ }^{98}$ Philonenko, A. op cit, pp. 17-18.
} 
seu "procedimento negativo" (GuW, p. 288), ela se esforça em se retirar. E como, através disso, a bela alma, a pura subjetividade encontrar-se-á negativamente contraposta a essa exterioridade numa espécie de "interioridade nostálgica" 99 que, muito embora exija a recusa de toda a relação com a existência sensível, permanece a ela inevitavelmente vinculada. Hegel escreve:

"na verdade, também o interior deve se tornar
exterior, a intenção deve obter efetividade na ação, o
sentimento religioso imediato se expressar no movimento
exterior e a crença, que foge da objetividade do
conhecimento, se tornar objetiva em pensamentos,
conceitos e palavras" (GuW, p. 290).

Nessa dependência em relação ao sensível, a subjetividade que se pretendia pura em seu conceito infinito, revelar-se-á sobretudo uma subjetividade abstrata que, através de uma abstração da sensibilidade e da existência empírica, consegue apenas angariar a qualidade de saber formal, de uma vacuidade; pois “o infinito, o conceito, como vazio em si [an sich leer], o nada, obtém seu conteúdo mediante aquilo a que está relacionado em sua contraposição” (GuW, p. 292). Hegel quer enfatizar a partir da constatação dessa contraposição fundamental no cerne dessa maneira de pensar, como essas filosofias fracassam na tarefa de se elevar à idéia enquanto "identidade absoluta", isto é, enquanto "única realidade verdadeira" (GuW, p. 302) e acabam inversamente por tornar absolutos ambos os termos contrapostos, tanto o conceito formal e abstrato (a subjetividade pretendida infinita), quanto a multiplicidade sensível (que do ponto de vista prático é a ação no mundo sensível) - tornando assim absoluta a própria contraposição: "Permanece nessas filosofias o ser absoluto do finito, da realidade empírica e a contraposição absoluta do infinito e do finito, e o ideal é compreendido como conceito" (GuW, p. 294).

A "identidade absoluta" que essas filosofias deixam de poder apreender como o saber verdadeiro é justamente aquela em que essa contraposição é tornada relativa e pela qual seus termos são ambos reconhecidos como abstratos e sem realidade em si e não como entidades realmente distintas: "porque a filosofia na identidade absoluta não reconhece como sendo para si nem um nem outro dos contrapostos na sua abstração do outro, mas apenas a idéia suprema, considerada indiferente em relação em de cada um

\footnotetext{
${ }^{99}$ Philonenko, op. cit. p. 18.
} 
isolado" (GuW, p. 302). O que resulta disso, afirma Hegel, é a própria negação dessas filosofias enquanto filosofias, posto que a "tarefa da filosofia verdadeira" (Aufgabe der wahren Philosophie) não é a de, permanecendo na oposição, colocar a identidade dos opostos como "fim da filosofia" (Ende der Philosophie), tornando-a seu "puro limite", o que seria uma "negação da mesma". Ao contrário "como tarefa da verdadeira filosofia não deve ser visto resolver ao fim [in ihrem Ende zu lösen] ${ }^{100}$ as oposições que se encontram e que ora são apreendidas como espírito e mundo, como alma e corpo, como eu e natureza etc., mas a sua única idéia, que tem realidade e objetividade verdadeira para ela é o absoluto ser suprimido da oposição (das absolute Aufgehobensein des Gegensatzes)" (GuW, p. 302). Não podendo corresponder ao único interesse da razão, a saber, "suprimir tais opostos tornados fixos", essas filosofias fracassam.

A escolha feita no texto de 1802 da oposição entre fé e saber como representante das demais contraposições das quais essas filosofias não conseguem se desfazer ${ }^{101}$, e que a verdadeira filosofia, de acordo com a sua necessidade e tarefa deve suprimir (aufheben) justifica-se pela similar relação que se estabelece nessas filosofias da fé o do saber com o Absoluto. Tanto para a fé, à qual a razão teve de "suprimir seu saber para dar lugar" 102 , quanto para o próprio saber, a relação com o Absoluto é aqui apenas negativa, isto é fixada numa contraposição, permanecendo ele para ambos sempre em um além inatingível. Do fato do saber, enquanto entendimento, não poder ir além de sua restrição ao mundo fenomênico e ao condicionado; e do fato de que o âmbito do que é "em si" lhe permanecer vedado, parece ser facilmente reconhecível que o incondicionado e absoluto esteja numa esfera além do saber, conclusão maior da filosofia teórica kantiana. Mas em que sentido uma "fé racional" (Vernunftglaube), isto é, uma crença fundada na própria "necessidade moral" e que tem na razão mesma sua fonte (Quelle) ${ }^{103}$ estaria também

${ }^{100} \mathrm{GuW}$, p. 302. A expressão "in ihrem Ende zu lösen" é traduzida na edição brasileira simplesmente por "resolver". Optamos por essa outra tradução para ressaltar o termo fim (Ende) - utilizado logo acima na expressão "fim absoluto da filosofia" - que visa mostrar como as filosofias da reflexão tem a resolução das oposições apenas em seu fim, isto é, não podem realizar em si senão como uma tarefa a ser cumprida num fim indeterminado.

101 "A cultura elevou a época recente tão acima da antiga oposição entre fé e razão, entre filosofia e religião positiva, que essa contraposição entre fé e sabe ganhou um sentido inteiramente outro e agora foi transferida para o interior da própria filosofia" (GuW, p. 287).

${ }^{102}$ Kant, KrV B XXX

${ }^{103}$ Cf. Kant, KpV, V, p. 126. 
fadada a essa distância? Não havia Kant, após haver recusado insistentemente qualquer extensão do conhecimento especulativo às idéias da razão, reafirmado, "sob o aspecto puramente prático", a "realidade objetiva" das idéias de Deus, da liberdade e da imortalidade da alma enquanto postulados, através da pressuposição necessária do princípio da moralidade? ${ }^{104}$

Hegel pretende mostrar em sua análise crítica como essas filosofias reflexivas que pretendem salvaguardar um lugar para a fé terminam inevitavelmente por submeter os "objetos da fé" aos mesmos ditames de um entendimento que aspira mantê-la à distancia de toda empiria - de modo que temendo correr o perigo de rebaixar de imediato o objeto da fé ao nível da sensibilidade, elas acabavam por fazê-lo mediante a elevação da empiria à categoria de quase revelação (o que fica imediatamente perceptível no caso particular de Jacobi, mas indiretamente também em Kant e Fichte que acabam por "fundamentar precisamente o empirismo moral e científico absoluto que tanto censuram no eudemonismo") (GuW, p. 297).

Como Hegel já escrevia nos textos da época de Frankfurt ${ }^{105}$, o que caberia à fé era a relação com aquilo que permitiria a unificação precisamente daqueles opostos nos quais a razão moderna se encontrava cindida: "Fé, escreve em Glauben und Sein, é a maneira como está presente em nossa representação o unificado [das Vereinigte], através do qual uma antinomia é unificada" (HW I, p. 250), de modo que o que é posto como objeto da fé (das Geglaubte) é a própria atividade de unificação desses contrapostos. Ou seja, precisamente em nome da resolução de uma antinomia da própria razão, intensificada ao extremo na época moderna, vem a fé estabelecer relação com a unidade pressuposta dos opostos. Porém, na medida em que essa atividade de unificação é apreendida enquanto objeto da reflexão e esse $\operatorname{ser}^{106}$ da unificação passa a ser crido, e na medida em que os

\footnotetext{
${ }^{104}$ Cf. Kant, KpV, V, p. 132.

${ }^{105}$ Cf. Entwürfe über Religion und Liebe, HW I, pp., 237-255.

${ }^{106}$ Nesse texto de Frankfurt, a relação entre fé e saber aparece ali desenvolvida como relação entre fé e ser (Sein), Hegel tomando de empréstimo a terminologia de Jacobi apresentada em Über die Lehre des Spinozas. O termo "ser", no entanto, está também diretamente vinculado à relação que Hegel mantinha nessa época com Hölderlin, no que se convencionou chamar de "Círculo de amizade" ou de a "união de espíritos de Frankfurt-Homburger" (Hegel, Hölderlins, Jacob Zwilling e Isaak von Sinclair ), no qual é desenvolvida a chamada "filosofia da unificação" (Vereinigungsphilosophie). Ser é o termo utilizado para essa unidade anterior à separação dos opostos: Cf. Hölderlin, Urteil und Sein. Ver também: M. Baum, Die Entstehung der hegelschen
} 
termos nele unificados são tomados como dados e primeiros, a própria unificação tornase novamente contraposta à fé que a engendra. Nova contraposição que exigirá mais uma nova unificação, repetindo isso num "regresso in infinitum" ${ }^{107}$. Portanto, para uma fé que busca no seu objeto o ideal de uma unificação de termos de antemão postos $e$ contrapostos de modo absoluto, toda unificação permanecerá incompleta e nunca chegará a se efetivar. E ao invés de uma "verdadeira unificação" 108 - e essa é a tese central que Hegel pretende expressar - as filosofias da reflexão tinham de permanecer na tarefa de unificar, no dever (Sollen) unificar ${ }^{109}$.

No que se refere à filosofia de Kant, como veremos, Hegel reconhece isso com clareza no sistema das idéias transcendentais, assim como na doutrina dos postulados, na qual a realidade objetiva das idéias da razão, obtida "mediante sua relação com o prático", revela-se apenas uma "condição subjetiva da razão" 110 que necessita de um princípio regulativo como fornecedor de uma regra para dar conta da tarefa (Aufgabe) por ela mesma atribuída ao entendimento de prosseguir na série de condições de um determinado condicionado ${ }^{111}$. Ou seja, o incondicionado (das Unbedingte), que por definição não pode ser objeto de nenhuma experiência, será contudo exigido pela razão e

Dialektik, pp. 48-56. Cf. também W. Jäschke, op, cit. p, 99, e K. Düsing, Das Problem der Subjektivität in Hegels Logik, pp. 50-70.

107 "Quando se parte do contraposto e dele se deduz uma unificação pressuposta resulta num regresso infinito, em que a cada vez a nova unificação é o crido. Assim, a apreensão do caráter de pressuposição [Vorausgesetztheit] de uma unificação para cada contraposição, e de uma unidade antinômica para toda oposição, apenas conduz a uma fé no ser dessa unificação, que é a cada vez outra". M. Baum, op cit. p, 51.

${ }^{108}$ O que Hegel está indicando já em Glauben und Sein, e que irá desenvolver mais intensamente apenas nos escritos de Jena, são as diversas formas possíveis de unificação, opondo às verdadeiras (que na época de Frankfurt são ensaiadas na noção de fé, vida e amor aquela que é ensaiada por uma fé subordinada às categorias da reflexão, tal como a fé racional de Kant.

109 "Todos os imperativos são expressos através de um dever (Sollen) e com isso mostram a relação de uma lei objetiva da razão com uma vontade que, de acordo com sua constituição subjetiva, não é através disso determinada de modo necessário (uma obrigação)" Kant, Grundlegung zur Metaphysik der Sitten, GMS, IV, p. 413.

${ }^{110}$ Cf. Kant, KpV, V, p. 125 e 145.

111 "Visto que mediante o princípio cosmológico da totalidade não é dado nenhum máximo à série de condições num mundo dos sentidos, considerado como coisa em si, e que no máximo apenas pode ser proposto como tarefa na regressão desta série, o citado princípio da razão pura conserva a validade no seu significado, assim corrigido, alías não como axioma para pensar como real a totalidade no objeto, mas como problema para o entendimento, ou seja, para o sujeito, permitindo estabelecer e prosseguir a regressão na série das condições de um condicionado dado, de acordo com a integridade da idéia”. Kant KrV, B536. Ver também KrV B379-380. 
colocado para ela como uma tarefa; tarefa essa que porém jamais é efetivamente concluída, visto que o incondicionado não poderá será encontrado - devendo apenas permanecer um postulado da razão:

“A idéia da razão, portanto, limitar-se-á a prescrever uma regra à síntese regressiva na série de condições, pela qual esta transitará do condicionado para o incondicionado mediante todas as condições subordinadas umas às outras, embora o incondicionado jamais se alcance" (Kant, KrV, B538) ${ }^{112}$.

A mesma exigência (Forderung) infinita Hegel encontra na filosofia de Fichte. Conforme a experiência ordinária da consciência empírica apresenta, o Eu encontra diante de si todo um âmbito que lhe é contraposto e que o limita, o Não-Eu. O Eu, porém, é reconhecido, desde o início, na infinitude do conceito, isto é, enquanto consciência de si é um "pôr absoluto" (absolutes Setzen) de si mesmo (Eu=Eu). Esse "Eu absoluto", essa "pura atividade que retorna a si mesma" (reine in sich selbst zurückgehende Tätigkeit) ${ }^{113}$, enquanto pura atividade, não sofre nenhuma resistência (Wider-stand) e, conseqüentemente, não pode se dirigir a nada que lhe esteja oposto (Wider), nenhum objeto (Gegen-stand). Todavia para se tornar inteligência (Inteligenz), essa "atividade que vai ao indeterminado e infinito" deve encontrar um travo (Anstoß), ou seja, ela deve se defrontar com um estranho (Fremdartige).

É, contudo, uma exigência da razão prática, que esse Não-Eu seja determinado de modo absoluto pelo Eu, isto é, que o Eu tenha "causalidade absoluta" sobre o Não-Eu. "Aquela exigência de que tudo deve coincidir [übereinstimmen] com o Eu, de que toda a realidade seja simplesmente posta pelo $\mathrm{Eu}$ é a exigência daquilo que se chama corretamente de razão prática" ${ }^{114}$. A exigência da razão prática é assim a de uma aniquilação de todo o mundo objetivo, de todo o Não-Eu, através de sua recondução ao $\mathrm{Eu}=\mathrm{Eu}$. Toda heterogeneidade (Ungleichheit) que for encontrada na consciência deve ser reconhecida, por sua vez, como também sendo resultante de uma atividade do Eu. Esse

\footnotetext{
112 Sobre a recepção da doutrina dos postulados kantiana por Hegel, ver Düsing, K. (1973) In: Hegel-Studien,, Bubner, R. Das älteste Systemprogramm. Studien zu Frühgeschichte des deutschen Idealismus, pp.52-90.

${ }^{113}$ Fichte, Grundlage der gesamten Wissenschaftslehre, 1794, GA I,2, p. 393.

${ }^{114}$ Fichte, Grundlage der gesamten Wissenschaftslehre, 1794, GA I,2, p. 399.
} 
dever (Sollen) é o mesmo que o dever kantiano, e na medida em que o Eu não pode se libertar completamente de toda "influência estranha" (fremder Einfluss) sobre si, o $\mathrm{Eu}=\mathrm{Eu}$ se revela uma mera idéia da nossa razão. $\mathrm{E}$ o $\mathrm{Eu}=\mathrm{Eu}$ de que se partira revelar-se-á agora como "esforço infinito" (unendliches Streben) - "Eu deve ser igual Eu". Trata-se portanto de um "postulado prático do dever absoluto [que] não exprime senão uma ligação pensada da oposição..." (DS, p. 68). Vemos, assim, como no âmbito das categorias reflexivas (entendimento), toda síntese possível está destinada a um além, na forma de um dever. Uma perseguição infeliz, afirmará Hegel, dado que tal tarefa, nesses termos colocada, tem como determinação jamais plenamente se realizar.

Voltemos, pois, novamente à questão da relação da fé com o absoluto tal como se configura nas filosofias da reflexão. O que é importante apontarmos aqui é como a ênfase da crítica que Hegel fazia ao abismo que se estabelecia entre a fé e o absoluto não está voltada à fé em geral e que ele não pretende retirar da fé e da religião, ao menos à época de Frankfurt, o poder de unificação que elas contém. Ao contrário, o divino, ao qual se dirige a fé, o "objeto da religião", é um tal ideal no qual sujeito e objetos, liberdade e natureza estão de tal forma unificados que não há sentido em atribuir realidade anterior a nenhum dos pólos dessa unidade. Todavia, quando esse objeto da fé, essa unificação é uma mera unificação exigida pela reflexão, uma idéia no sentido kantiano, e "a unificação apenas uma representação [eine Vorstellung], um pensado [ein Gedachtes]", então a fé tem diante de si uma representação de uma unificação por se fazer e permanece a ela contraposta numa distância ${ }^{115}$. "Não podemos colocar o ideal fora de nós - senão ele seria um objeto - nem somente em nós, senão não seria nenhum ideal” (HW I, p. 244).

O que Hegel está assim indicando desde os textos de Frankfurt é sobretudo a necessária diferenciação de formas distintas de unificação, sendo que aquela representada por uma fé subordinada às categorias da reflexão, isto é, uma fé que se volta ao seu objeto enquanto fundamento (Grund) ou condição (Bedingung) dos opostos, meramente por uma exigência decorrente da infinita cadeia causal estabelecida pelo entendimento é

\footnotetext{
115 “A certeza imediata da crença da qual tanto se falou como o último e supremo da consciência, não é senão a própria identidade, a razão, mas que não se conhece a si mesma e é acompanhada da consciência da oposição". Hegel, DS, p. 32.
} 
uma unificação incompleta (unvollständiges Vereinigung) ${ }^{116}$. Essa subordinação da fé à reflexão é o sinal de que o absoluto aqui é somente uma exigência racional, que todavia se expressa e se compreende no interior das limitadas exigências do entendimento. E a conseqüência necessária é a tarefa de unificar, o dever de realizá-la, mas a permanência da oposição: "a teimosia do entendimento [Eigensinn des Verstandes] permite que a oposição do determinado e do indeterminado, da finitude e da infinitude abandonada [aufgegebene Unendlichkeit], permaneça lado a lado de modo não unificado", e, portanto, por unificar ${ }^{117}$. E com isso, todo o mérito da filosofia kantiana de ter se afastado das religiões positivas na medida em que, através da recusa de qualquer forma de autoridade externa para sua razão auto-legisladora, transformava a relação de mera legalidade instituída por um mandamento autoritário numa relação de moralidade através de uma “subjetivação das proposições de fé objetivas" ${ }^{118}$, recaía novamente numa "fé positiva" 119. A lei agora subjetivada, uma lei do homem, permanecia, no entanto, ainda em situação de contraposição e se impunha enquanto "obrigação" (Nötigung) e "dominação" (HW I, p. 301). "Filosofia kantiana - escreve Hegel em 1797/1798 - religião positiva" 120

Assim a fé, que deveria recuperar a defasagem surgida pela relação do saber com o absoluto, acabava por estabelecer uma relação similar àquela nessas filosofias da

\footnotetext{
${ }^{116}$ Cf. Baum, M. op cit, p. 50.

117 Um breve comentário sobre a tradução portuguesa de Morujão para essa frase. Para a expressão: „vermag die Entgegensetzung (...) unvereinigt nebeneinander bestehen zu lassen“, ele oferece a tradução: "permite que a oposição (...) permaneça lado a lado por unificar". No original alemão não há essa expressão "por unificar", mas apenas "não unificado" (unverenigt). Todavia a tradução oferecida não deixa de estar correta pois a compreende no interior do texto hegeliano em que o unverenigt é para ser compreendido como aquilo que ainda não foi unificado e, portanto, que está por unificar.

${ }^{118}$ Cf. Görland, I. Die Kantkritik der jungen Hegel, p. 7.

119 “'A 'religião da razão' (...) é por consequência o análogo exato da religião positiva nisso que concerne À antinomia reflexiva fundamental da possibilidade e do ser. A fé racional não implica como a fé positiva recurso a uma fonte milagrosa ou a uma garantia sobrenatural; mas todos os paradoxos da dicotomia reflexiva entre ser e dever-ser surgem da mesma maneira nas duas formas de fé". Harris, H. Le Développement de Hegel I, p. 247.

${ }^{120}$ Glauben und Sein, HW I, p. 254. Hegel chama de "fé positiva" aquela que se define por "um sistema de proposições religiosas tal que deve ter verdade para nós porque nos foi ordenado por uma autoridade a que não podemos recusar de submeter nossa fé" (Zusätze zu Positivität der Christliche Religion, HW I, p. 190). Sobre a crítica hegeliana da moral kantiana nos textos de juventude ver Düsing, K. op. cit, pp. 38-50. Ver também Beckenkamp, J. O jovem Hegel. Formação de um sistema pós-kantiano, pp. 77-125.
} 
reflexão, apresentando modos apenas incompletos de unificação, e consolidando de vez o dualismo que nelas impera. O caráter insatisfatório dessas formas de unificação dos contrapostos que caracterizam o dilaceramento (Zerrissenheit) da consciência moderna ensaiadas pelas filosofias da reflexão talvez fique ainda mais claro a partir da identificação que Hegel faz dos princípios do Iluminismo e do Eudemonismo, doutrinas à primeira vista essencialmente distintas. Com ela Hegel visa indicar o aspecto mais incisivo de sua crítica, que a orienta desde o início e que se pode traduzir na pergunta: qual o estatuto dessa subjetividade, dessa razão nas filosofias de Kant, Fichte e Jacobi?

Hegel quer responder a isso a partir das conseqüências imediatas que resultam das unificações incompletas e reconciliações insatisfatórias experimentadas por essas filosofias. A contraposição da subjetividade e do mundo sensível, afirma Hegel, podia apenas encontrar nelas uma reconciliação na doutrina da bem-aventurança (Glückseligkeitslehre), para a qual, no entanto, o supremo deleite somente poderia ser reconhecido, em sua idealidade, através do próprio fazer racional, isto é, de forma isolada e novamente contraposta à sensibilidade - o que acabava por anular essa recém-ensaida reconciliação: "pois se a bem-aventurança é compreendida como idéia, ela deixa de ser algo contingente, bem como algo sensível" (GuW, p. 292). Tratava-se então novamente de uma "má reconciliação" ${ }^{121}$, mas que agora tinha um sério agravante. Ao invés de suprimir o sensível numa unidade com o agir racional, essa tentativa o elevava imediatamente em sua forma ordinária à condição de deleite supremo, rebaixando assim a razão ao nível da sensibilidade. A conseqüência dessa reconciliação insatisfatória era então a manutenção da contraposição - agora entre a existência empírica e a boa consciência do fazer racional - e a sua transposição para o interior da empiria:

"Depois de chegado o tempo, o anseio infinito para além do corpo e do mundo teria se reconciliado com a existência, mas de tal modo que a realidade, com a qual se deu a reconciliação - o objetivo que foi reconhecido pela subjetividade -, era efetivamente apenas existência empírica, mundo e efetividade ordinários. Por conseguinte essa reconciliação mesma não perdeu o caráter da contraposição absoluta que reside no belo anelo [schonën

${ }^{121}$ Jäschke, W. op. cit. p. 139. 
Sehnen], mas se lançou para o outro lado da oposição, para o mundo empírico" (GuW, p. 291).

Se, portanto, nenhuma unificação completa se mostra possível quando o finito da multiplicidade sensível e do deleite é previa e categoricamente fixado numa oposição à subjetividade, a unificação a que a razão será levada pelos seus próprios interesses será aquela que exige dela um rebaixamento ao nível do entendimento. O que significa, em outras palavras, que a própria configuração de sua tarefa é em si mesma um impedimento à sua realização. O resultado desse "preconceito da finitude" - para usar um termo proposto por Lebrun ${ }^{122}$ - que estava na base de toda as tentativas mal-sucedidas de unificação, não era a simples permanência de um “em si” inalcançável e de um resto de multiplicidade que jamais seria totalmente recoberta pelo conceito, mas a conseqüência imediata era a finitização dessa subjetividade, finitização da razão. Pois elas incorriam sempre no mesmo equívoco de buscar atingir a infinitude a partir da contraposição com o finito. Porém, como Hegel faz questão de apontar, "se a infinitude é contraposta à finitude, então uma é tão finita quanto a outra" (GuW, p. 297).

"Quanto mais diametralmente essas filosofias se contrapuserem ao eudemonismo, tanto menos se afastaram dele. É a sua única tendência pura e simplesmente expressa - e um princípio dado por elas - elevar-se acima do subjetivo e empírico e reivindicar para a razão o seu ser absoluto e sua independência diante da efetividade ordinária. Todavia, porque essa razão tem pura e simplesmente apenas essa orientação contra o empírico, o infinito em si é apenas em relação ao finito, então essas filosofias, na medida em que combatem o empírico, permaneceram imediatamente em sua esfera" (GuW, p. 296).

Dito de outra maneira, não bastava o esforço interminável de purificar o finito e a subjetividade de sua relação com a sensibilidade através do simples relacionar a finitude ao infinito do conceito, "pois esse infinito não é ele mesmo o verdadeiro, porque não é capaz de consumir [aufzehren] completamente a finitude" (GuW, p. 300). O que está sendo posto em xeque nessa afirmação de Hegel é, assim, o próprio estatuto do finito, o qual essas filosofias mantinham intacto. Toda relação com o absoluto e com a

${ }^{122}$ Lebrun, A Paciência do Conceito, p. 194. 
"verdadeira infinitude" 123 é mediada por uma reflexão e subjetividade finitas, de modo que a razão ali permanece na negatividade da antinomia em que se encontra. "Para a reflexão não é possível nenhuma outra concepção do absoluto senão através da antinomia", sendo esta agora fixada absolutamente nas filosofias da reflexão, fazendo com que a idéia de infinitude à qual elas conseguem chegar "deva permanecer uma idéia em sentido kantiano, absolutamente oposta à intuição" (DS, p. 70).

Dessa forma, a filosofia de Fichte e a de Jacobi, assim como a filosofia kantiana que Hegel chamará anos mais tarde de "o iluminismo feito de modo metódico" (VGPh, HW XX, p. 331), serão igualmente marcadas pelo "ser absoluto da oposição" (das Absolutsein des Gegensatzes), com a simples diferença de que enquanto a filosofia kantiana e fichteana esforçar-se-ão em alcançar sua auto-legitimação no conceito, através da anulação não plenamente realizada do estatuto ontológico da empiria, a filosofia de Jacobi buscará uma reconciliação com esse aquém empírico de modo imediato, transmutando toda a objetividade em uma subjetividade fervorosa, que toma "a efetividade e a temporalidade ordinárias como revelação", ou seja, fazendo da certeza sensível o verdadeiro, e da razão um mero "instinto e sentimento" (GuW, p. 391) :

"A filosofia jacobiana não recorre ao desvio que consiste em separar o conceito da realidade empírica e, então, deixar que o conteúdo seja dado de novo ao conceito justamente por essa realidade empírica, além da qual não há nada para o conceito senão sua aniquilação. Mas já que o seu princípio é imediatamente subjetividade, ela é eudemonismo imediato..." (GuW, p. 296) ${ }^{124}$.

\footnotetext{
${ }^{123}$ Desde a época de Jena Hegel já apresenta diferentes "formas de infinitude", como fará até suas últimas obras. Diferentemente do verdadeiro infinito da idéia absoluta (identidade do universal e do particular) a "má infinitude" é caracterizada pela sua abstração, pelo seu caráter formal e pelo "progresso infinito" a que está vinculada. Hegel ainda oporá a essas duas formas de infinitude - a primeira, da razão absoluta, e a segunda da razão formal kantiana e do Eu fichteano - uma terceira forma de infinitude que será a empírica, tal como julga encontrar em Jacobi. Cf. Hegel, GuW, p. 352.

${ }^{124}$ Hegel chega a falar que enquanto "a filosofia kantiana põe a subjetividade e a finitude absolutas em uma abstração pura e, com isso, ganha a objetividade e a infinitude do conceito, a jacobiana não assume a finitude ela mesma no conceito, mas faz dela princípio como finitude finita [endliche Endlichkeit], como contingência empírica e consciência dessa subjetividade" (GuW, p. 387).
} 
Dessa forma, em todas elas reina o princípio da subjetividade, o que implica que a “divinização do sujeito" que perpetram é, antes de mais nada o enaltecimento de uma subjetividade psicológica marcada pela finitude.

Coroando essas sérias acusações feitas por Hegel em Fé e Saber encontramos como o seu núcleo ordenador a tese que podemos indicar num questionamento feito logo no início do ensaio:

"Permanece, contudo, a questão de se a vitoriosa razão não sofreu justamente o mesmo destino que o poderio vitorioso das nações bárbaras costuma ter diante das forças derrotadas de nações mais instruídas: conservar o domínio externo na mão superior, mas submeter o espírito aos vencidos" (GuW, p. 287).

Teria então essa razão esclarecida após sua longa e difícil empreitada de examinar minuciosamente seu saber e de afastar de si todo aspecto de fé injustificado e que ela julgava a si mesma contraposta - teria ela permanecido razão (Vernunft)? Diante do temor, tornado metódico, de não tornar positivo o espaço vazio da fé; diante da convicção de deixar indecidido qualquer juízo acerca do que não se submete às limitadas e limitantes categorias do entendimento; realizada a disciplina necessária para conter os impulsos e extravios especulativos em direção ao incondicionado; e restringido seu saber às exigências do entendimento; teria, enfim, a razão - essa "faculdade suprema do conhecer", conforme uma das várias definições dessa faculdade que Kant afirmava ser embaraçoso definir (KrV, B355) - se mantido razão?

Que razão pode ser essa que se caracteriza pelo afastamento em relação ao empírico, tendo como seu objeto o incondicionado e como seu produto as idéias mais elevadas, e que, no entanto, se encontra aqui completamente afetada por ele? Esse é, afirma Hegel, o estatuto da razão resultante da "cultura da reflexão" (Kultur de Reflexion): uma razão que aprende a renunciar às suas próprias ambições, pensa-se nobre nessa sua humildade, mas mal se apercebe da sua equiparação ao "entendimento humano ordinário" (gemeiner Menschenverstand). 


\section{Reflexão e Crítica: A filosofia de Kant}

"Reconstruir um kantismo bem centrado é desde já desconhecer, na obra, o seu quinhão de incerteza e indecisão" (G. Lebrun, Kant e o Fim da Metafísica, p. 388).

Vimos até aqui como Hegel denomina a filosofia kantiana de uma "filosofia da reflexão" e já indicamos, anteriormente, como essa própria denominação carrega consigo uma tensão que nela se expressa dependendo da alteração de seu acento. Trata-se, pois, simultaneamente, de uma filosofia da reflexão, na qual a reflexão, seguindo o sentido do genitivo subjetivo, é o caráter dominador desse sistema, assim como de uma filosofia da reflexão, ou seja, de uma filosofia que assume a forma da reflexão, mas que não se resume a ela. A leitura que Hegel faz dessa filosofia caminha, como pretendemos indicar nesse trabalho, no sentido de reconhecer a filosofia que se recusa a se restringir à forma de um sistema da reflexão, de modo que filosofia da reflexão significa para Hegel, fundamentalmente, uma exigência, uma tarefa: elaborar uma reinterpretação do sentido da reflexão no texto kantiano e buscar o aprofundamento da própria reflexão que ali opera. Nesse sentido, poderíamos dizer que a tarefa especulativa, nascida do interior da crítica, a partir de sua leitura, é a de ser uma autêntica filosofia da reflexão, ou, em outras palavras, a de reconduzir a reflexão finita da filosofia kantiana para sua origem filosófica enquanto reflexão especulativa, aprofundamento submetido agora à ordem da infinitude.

Para que possamos perceber essa reinterpretação especulativa da reflexão em jogo na leitura hegeliana, devemos nos voltar para o papel que a reflexão desempenha na filosofia crítica anteriormente a essa re-transcrição, mas como que já à luz desta. Isso significa que devemos aprofundar a relação estabelecida entre filosofia crítica e filosofia da reflexão, e buscar compreender a dimensão desta reflexividade crítica, consideração sem a qual toda avaliação da própria natureza desta filosofia parece ficar comprometida ${ }^{125}$. Em outras palavras, devemos agora colocar em foco a relação entre crítica e reflexão.

${ }^{125}$ Cf. Marques, A. A Razão Judicativa, p. 75: "Pretendemos mostrar que a avaliação da natureza crítica da sua filosofia [a de Kant] passa em grande parte pela avaliação do conceito de reflexão ou das formas que esse conceito adquire em momentos diferentes das suas obras". 
Abordar exaustivamente a noção de reflexão na obra kantiana é uma tarefa que, sem dúvida alguma, exigiria um trabalho a parte ${ }^{126}$. Trata-se de uma noção que contém diversos sentidos no corpus kantiano, ganhando significações distintas em função do contexto no qual é empregada ${ }^{127}$. Para que permaneçamos fieis ao nosso percurso, e evitemos um extravio em questões de uma outra ordem e dimensão daquela que aqui temos em vista, nosso enfoque na busca de uma caracterização da reflexão na obra kantiana tem de estar diretamente ligado ao aspecto em que ela exprime o próprio pensar em jogo na filosofia crítica, e, nesse sentido, nos permite, através dela, tematizar o próprio estatuto do discurso crítico. Devemos ter como horizonte de nossa abordagem da reflexão a maneira como ela organiza o pensamento kantiano e se revela como instância fundamental de sua filosofia. Ao mesmo tempo, uma vez que temos como ponto de partida a censura feita por Hegel às filosofias da reflexão, temos de caminhar no sentido de manifestar a tensão presente no conceito kantiano de reflexão, mantendo, portanto, como horizonte constante a instabilidade a que a figura da reflexão responde e com isso, a maneira como nessa filosofia já encontramos o anúncio de um aprofundamento para além dos contornos da filosofia crítica.

Se pudermos, pois, apreender uma certa unidade, um fundo comum ${ }^{128}$, que se permite traçar sobre a noção de reflexão em Kant, em torno da qual podemos reconhecer a gravitação da filosofia crítica, poderemos nos aproximar da leitura que Hegel dela faz e da razão do surgimento da exigência de um aprofundamento dessa reflexão ${ }^{129}$. São portanto essas duas interrogações que devem nos orientar nessa exposição: $\alpha$ ) Em que medida a reflexão é a instância fundamental da crítica (filosofia crítica qua reflexão)? $\beta$ )

\footnotetext{
${ }^{126}$ A bibliografia kantiana acerca desse tema não é pequena. Ressaltamos os trabalhos de P. Reuter Kants Theorie der Reflexionsbegriffe (1989), A. Grandjean Critique et Réflexion (2009), B. Longuenesse Kant and the Capacity to Judge (1998) e M. Liedtke Der Begriff der Reflexion bei Kant (1966).

${ }^{127}$ Uma organização dos sentidos gerais do termo reflexão na obra kantiana encontramos em Reuters, op cit, pp. 82-109, em Grandjean, op cit, pp. 78-87 e no artigo de Liedtke, pp. 207-216.

${ }^{128}$ Grandjean, A. 'Le concept de 'réflexion' se presente sous des figures multiples, en divers lieu du corpus kantien. Cette multiplicité ne fait toutefois que distribuer un fonds commun, de sorte qu'elle ne signifie aucune homonymie.", p. 78.

${ }^{129}$ Não estamos sugerindo aqui que Hegel tenha tomado a reflexão kantiana em apenas um de seus aspectos. Pelo contrário, nossa indicação da diversidade significativa em jogo no termo reflexão pretende mostrar como é a partir dela, enquanto caracterizando as polaridades da filosofia crítica, que Hegel desenvolve um aprofundamento e uma reiterpretação da reflexão.
} 
Em que medida a reflexão na filosofia kantiana, como instância fundamental do pensar crítico, carrega consigo a exigência de um aprofundamento e ultrapassamento?

\subsection{Reflexão: instância fundamental da crítica}

a) Em que medida a reflexão é a instância fundamental da crítica?

Como dissemos, a noção de reflexão varia em relação ao contexto em que Kant a emprega e embora essa multiplicidade semântica, que está diretamente associada às diversas funções que a reflexão assume na obra de Kant, não possa ser abordada aqui em seus pormenores, não devemos ver nessa sua diversidade um obstáculo para a caracterização que pretendemos, mas, antes, o indício de uma tensão a que esta noção responde. Nesse sentido é importante que indiquemos as fronteiras nos modelos de reflexão que a filosofia crítica põe em marcha, discernindo as diversas operações a que Kant denomina de reflexão, e reencontrando nelas as características gerais do próprio fazer crítico. Tomamos como via de acesso à reflexão em operação no empreendimento crítico o contexto geral em que se coloca a articulação entre reflexão e a tarefa crítica.

O horizonte geral da relação entre reflexão e crítica é colocado pela Kritik der reinen Vernunft através da famosa metáfora do "tribunal da razão", segundo a qual a razão volta-se a si mesma na qualidade de juíza e de ré para, através dele, "assegurar suas pretensões legitimas e condenar todas as suas pretensões infundadas" (KrV, A XI, XXI) ${ }^{130}$. Esse tribunal que a razão estabelece para determinar e julgar os seus direitos passa a existir a partir de um amadurecimento da razão que é necessariamente acompanhado pelo reconhecimento de que sem ele, ou seja, sem uma crítica da razão, esta se encontra enredada em meio a prejuízos (Vorurteil) que destinam a razão a um "mero tatear" (bloßes Herumtappen) no que diz respeito à busca daquilo que lhe é mais importante (metaphysica specialis). A exigência da Crítica é a de questionar os fundamentos da incerteza e da insegurança nas investigações metafísicas, e as razões de seu contraste com os demais saberes já estabelecidos que já seguiram "a via segura da ciência", de modo a restringir aquilo que Kant chama de "dogmatismos da metafísica" e que dizem respeito à toda longa tradição filosófica pré-crítica.

${ }^{130}$ Cf. também, B 697, B 779. 
A partir desse reconhecimento compartilhado por toda a Aufklärung alemã, a saber, o de que sem a fundamentação de uma distância crítica em relação às formas de vida tradicionais estamos necessariamente fadados a permanecer em estado de Unmündigkeit - isto é, a permanecer num estado de inevitável heteronomia cognitiva e prática, em que o princípio geral de condução das ações humanas não tem sua origem em um "uso do próprio entendimento" (WA, p. 35), a partir desse reconhecimento, pois, é que se instaura a tarefa crítica e a busca de não apenas eliminar o erro, mas, antes de tudo, buscar compreendê-lo em sua origem ${ }^{131}$. Essa crítica prática exercida aos prejuízos, acompanhada da exigência de uma reflexão teórica livre e autônoma torna-se assim, nessa "época da Aufklärung" ou "época da crítica" (Zeitalter der Kritik) ${ }^{132}$, uma “importante necessidade filosófica" ${ }^{133}$. A exigência implícita na noção de Mündigkeit do iluminista, e que Kant desenvolve à sua maneira, era a de buscar fundamentar epistemologicamente detreminados juízos, que sem uma reflexão teórica acerca de sua legitimidade deveriam ser tomados como pré-juízos. A necessidade da reflexão, enquanto busca pela validação dos juízos, faz com que o sentido primeiro da reflexão teórica esteja diretamente associado à idéia de "prevenção de prejuízos". A intenctio recta (cognitio) torna-se no, âmbito crítico, intenctio obliqua (reflexio), e a atenção do filósofo é agora voltada para seus próprios atos de julgar e as razões que o levam a tal ou qual juízo determinado, tendo como pano de fundo as possíveis fontes de engano e ilusão. Esse combate aos "juízos apressados", a investigação acerca da origem dos enganos da razão, e a clarificação das instâncias de legitimação de um juízo constituem os temas abordados naquilo que se convencionou chamar de "teoria dos prejuízos" desenvolvida por Kant nas Logikvorlesungen, onde encontramos uma exigência reflexiva semelhante àquela que está na base de todo o projeto crítico ${ }^{134}$.

Todos os juízos e afirmações resultantes da menoridade, da heteronomia de uma razão que se mantém passiva, devem ser colocados agora em questão. "O prejuízo é o

${ }^{131}$ Cf. Lebrun, G. Kant e o fim da Metafísica, pp. 59-65.

${ }^{132}$ Cf. Kant, WA, p. 40 e também KrV A XI nota.

133 "A crítica aos prejuízos era um aspecto central da formação teórica filosófica da época da crítica”. Cf. Heßbrüggen-Walter, S Topik, Reflexion und Vorurteilskritik: Kants 'Amphibolie der Reflexionsbegriffe' im Kontext", pp. 152-3.

${ }^{134} \mathrm{O}$ artigo já citado de $\mathrm{S}$. Heßbrüggen-Walter busca mostrar como é nessa crítica aos prejuízos, desenvolvida nos cursos de lógica, que podemos reconhecer o contexto no qual a reflexão é abordada no capítulo da Anfibolia da Crítica da Razão Pura. 
principium de um uso passivo da razão" (Rx 2526, XVI, p. 405), algo que contradiz a própria natureza ativa da razão (contradictio in adjecto), que é considerada como "um princípio ativo que não pode ser tomado de empréstimo de outrem" ${ }^{135}$. Tal passividade, afirmava Kant, tem como origem quase que exclusivamente a "preguiça dos homens que preferem andar sobre pegadas alheias a querer intensificar suas forças" ${ }^{136}$. Nesse contexto, passividade e ausência da reflexão são diretamente vinculadas, e abarcam as distintas fontes de prejuízos - "1. Imitação [Nachahmung], 2. Hábito [Gewohnheit] e 3. Inclinação [Neigung]" tal como são repetidamente tematizadas nos cursos de lógica ${ }^{137}$. Tais fontes conduzem um juízo a determinar como objetivo algo que tem causas meramente subjetivas e que não ultrapassam essa esfera privada, não podendo, portanto, senão na medida em que constituem um erro, receber simultaneamente o estatuto de um juízo objetivo ${ }^{138}$. Nas palavras de Kant, "julgar um princípio subjetivo que de maneira incorreta é tomado por objetivo: Prejuízo" (Rx 2530, XVI, p. 406). Em oposição à pressa característica dos prejuízos, a reflexão surge, portanto, como instância de mediação, distância necessária para a validação objetiva de todo juízo.

Nesse sentido o reconhecimento dos possíveis erros de nosso ajuizar oriundos de um uso passivo da razão, assim como a tomada de consciência do caráter problemático de juízos específicos exige uma suspensio judicii nostri, isto é, uma suspensão do caráter determinante de um juízo e a sua conservação com um caráter de provisoriedade ${ }^{139}$. Essa suspensão, que não se confunde com a suspensio cética - pois não se trata de uma decisão de abstenção completa de julgar (renunciatio judicii) -, é antes de qualquer coisa a indicação da tarefa de "buscar as razões dos juízos determinantes" ${ }^{140}$. Esse é o sentido daquilo que Kant, na esteira da Vernunftlehre de Meier, chama de "juízo provisório" (vorläufiges Urteil), buscando com ele demarcar a diferença fundamental que esses

\footnotetext{
${ }^{135}$ Kant, V-Lo/Pölitz, XXIV, p. 548.

${ }^{136}$ Kant, V-Lo/Pölitz, XXIV, p.549.

137 "Praejudicium ist ein Grundsatz zu Urtheilen, der vor der Überlegung vorher geht. Grundsatz einer passiven Vernunft”. Kant, Rx (2548), XVI, p. 411.

${ }^{138}$ Cf. Kant, V-Lo/Pölitz, XXIV, p. 547.

139 "Wenn wir bisweilen können Fehler in unserm Erkenntniß finden, so können wir von ohngefehr darauf kommen durch Vergleichung mit anderen Erkenntnißen, auf unser Urteil mißtrauisch zu werden, woraus suspensio judicii nostri ensteht, welches der Vorsatz ist en vorläufiges Urteil nicht ein bestimmendes werden zu lassen”, Kant, V-Lo/Pölitz, XXIV, p. 545.

${ }^{140}$ Kant, V-Lo/Pölitz, XXIV, pp. 546-47.
} 
mantêm com os prejuízos: "Juízo provisório não é o prejuízo, mas é uma precaução [Behuttsamkeit] para evitar tal prejuízo" (Rx 2523, XVI, p. 404). Essa cautela que se refere a esse “análogo do prejuízo" ${ }^{141}$ - afinal os pré-juizos também são fundamentalmente juízos provisórios (judicium praevium), mas que, porém, são mal compreendidos na medida em que são tomados como juízos determinantes e objetivos (ambos tem em comum o fato de preceder a uma investigação) ${ }^{142}$ - é precisamente uma ação da reflexão (Überlegung) que se recusa ao juízo apressado e, estabelecendo seu caráter problemático e provisório, exige que dele se faça um exame: "Judicium reflectens, no qual um juízo se compara [gleich setzt] a um problema, para se investigar a verdade" 143 .

A distinção, que apenas uma distância reflexiva permite realizar, entre o juízo provisório e o prejuízo é de fundamental importância para a compreensão do papel central que os juízos provisórios, em associação com a reflexão, possuem no processo de conhecimento; e devemos ter precisamente esse ponto em vista se quisermos poder medir a transformação que o "reflektieren" sofre ao longo da obra kantiana. É na articulação entre ambos (reflexão e juízo provisório) que encontramos as condições necessárias para a formulação de um juízo verdadeiro. Kant reconhece, desde cedo, que os juízos provisórios desempenham uma função heurística significativa para toda forma de investigação, na medida em que eles orientam o exame segundo princípios na forma de máximas: "Praevia judicia, isto é, juízos provisórios são de grande importância, na medida em que com eles se tem certas máximas para a investigação provisória de uma questão" ${ }^{144}$. Não apenas o reconhecimento do caráter provisório desses juízos, mas

${ }^{141}$ Kant, V-Lo/Philippi, XXIV, p. 425.

142 "Prejuízos são juízos provisórios que são mal compreendidos em sua natureza e função. (...) São juízos apressados, isto é, juizos que não foram precedidos por nenhuma reflexão". La Rocca, C. Vorläufige Urteile und Erkenntniskraft. Zur heuristischen Logik des Erkenntnisprozesses. pp. 353-355.

143 Kant, V-Lo/Dohna, XXIV, p. 737. Note-se como a noção de "juízo reflexionante" (reflektierende Urteilskraft), que aparecerá explicitamente apenas na terceira crítica, já se encontra aqui esboçada com seus traços fundamentais. A continuação desse trecho permite essa afirmação sem a menor hesitação: "Também para o procurar [Suchen] precisa-se de um princípio particular. Buscar isso pertence à faculdade de julgar [Urteilskraft]. Não se pode ensiná-los. Pois se se quisesse fornecê-la regras, então já usaria a faculdade de julgar, para sob essas regras subsumir. Um judicium praevium parte portanto antes da investigação; mas com a reflexão deve a todo momento coincidir".

${ }^{144}$ Kant, V-Lo/Wiener, XXIV, p. 862. 
também a determinação correta da função que a eles cabe no processo de julgar objetivo é entendida como constituindo o trabalho da reflexão. Esta realiza, nesse sentido, uma regulação e uma orientação do conhecimento através de um auto-exame das condições de possibilidade de validação de um determinado juízo. Esse aspecto da reflexão vinculado à regulação e orientação de toda investigação, e necessário ao conhecimento, será um tópico central do desenvolvimento que Kant dá a essa ação quando se tornar o foco de uma investigação própria, na $3^{\text {a }}$ Crítica. Até aqui vemos como a idéia de reflexão opera no horizonte geral de uma distância crítica e da precaução (Behutsamkeit) que ela instaura em todo julgar que se pretenda objetivo.

Tendo esse contexto geral como horizonte, podemos afirmar que a tematização da reflexão no âmbito de uma filosofia crítica surge através de duas questões principais: da pergunta pela gênese do juízo, que pode revelar o seu caráter de prejuízo pelo simples fato de se reconhecer a heteronomia cognitiva na sua origem, assim como também através da pergunta pela possibilidade de legitimação de uma determinada relação de representações em um determinado juizo. É exatamente devido a esse seu segundo aspecto que já nas Logikvorlesungen Kant enfatiza a distinção - que reaparecerá quase inalterada no texto da $1^{\text {a }}$ Crítica - entre reflexão (Überlegung) e investigação (Untersuchung); uma investigação é exigida para todos aqueles juízos que não são de imediato evidentes e que devem receber uma fundamentação a partir da verdade fornecida pelos elementos que o compõem, isto é, devido à origem das representações que são ligadas no juízo (KrV, B316-317). A reflexão, por sua vez, é necessária para todos os juízos, mesmo para aqueles imediatamente evidentes (como no caso do juízo apodíctico que afirma que "entre dois pontos somente pode haver uma linha reta" ${ }^{145}$ ), pois é a exigência de uma consciência que se volta àquilo que pensa ${ }^{146}$, e que nesse retorno busca a instância de sua possível legitimação. "No primeiro caso trata-se da aceitação ou recusa de proposições, no segundo caso trata-se da execução de um processo

\footnotetext{
${ }^{145}$ Kant, KrV B317. Cf. também, V-Lo/Wiener, XXIV, p. 863; e V-Lo/Pölitz, XXIV, p.547.

146 "Es ist ein Unterschied zwischen untersuchen und überlegen. Viele Sätze können ohne Untersuchung angenommen werden $z$. $E$ daß das Ganze gleich sey allen Teilen zusammengenommen, aber überlegen muß ich es doch, $d$. h. ich muß mir bewußt seyn was das ist was ich denke”. Kant, Lo/Pölitz, XXIV, p.547.
} 
correto de conhecimento" ${ }^{147}$ e, portanto, imprescindível. A reflexão, que nesse sentido tem uma participação metacognitiva ${ }^{148}$ fundamental no processo de conhecimento objetivo, realiza a comparação (Vergleichung) das representações entre si nele contidas e entre elas e as fontes do conhecimento (Sensibilidade e Entendimento), instâncias em que um juízo pode encontrar sua legitimação - ação que será melhor esclarecida e desenvolvida na obra de 1781 sob o nome de reflexão transcendental, como abordaremos mais abaixo.

Na Logik Blomberg a comparação exercida pela reflexão é apresentada em nítido contraste com as fontes de engano, conforme a seguinte passagem:

“A reflexão não é outra coisa do que a comparação de um conhecimento com as leis do entendimento e da razão; não somos, porém, dirigidos meramente através das leis do entendimento e da razão, mas também freqüentemente por meio de inclinações ou pelo nosso gosto; nas inclinações não ocorre nunca nenhuma reflexão" (Kant V-Lo/Blomberg, XXIV, p, 165).

Como a nossa direção não é exclusivamente a do entendimento, uma comparação "de um conhecimento com as leis do entendimento e da razão" é necessária para que o juízo não afirme, de maneira irrefletida, como objetivo aquilo que tem valor meramente subjetivo. Essa comparação deverá levar em consideração as faculdades do conhecimento na medida em que deve reconhecer qual instância está em jogo na procedência de tal juízo, e avaliar se a relação objetiva pretendida pelo juízo se legitima a partir das faculdades de onde o conhecimento provém:

"pois quando um conhecimento [Erkenntniß] surge da influência de uma faculdade de conhecimento [Erkenntnißkraft], a qual não tem nenhuma validade em relação a esse objeto, então esse conhecimento deve ser rejeitado ou suspenso. Devo ver se são os sentidos ou o entendimento ou a imaginação que está aqui em jogo; pois todos os erros residem no fato em que a sensibilidade se

\footnotetext{
${ }^{147}$ La Rocca, C. op. cit, p. 356.

${ }^{148}$ La Rocca, C. op. cit, p. 354. O estatuto metacognitivo da reflexão será um dos alvos centrais da crítica hegeliana à reflexão crítica, na medida em que recusa a ela um participação cognitiva efetiva, conforme trataremos mais abaixo.
} 
influencia no entendimento" (Kant, V-Lo/Wiener, XXIV, p. 863) $)^{149}$

Vemos, assim, como a ação de refletir está diretamente relacionada à idéia de suspensão do juízo, ou seja, de uma distância crítica que instaura uma precaução em relação a toda determinação de conhecimento e, por conseguinte, à tarefa de examinar as instâncias de legitimação de um juízo. Sem uma reflexão, portanto, não se alcança nenhuma "convicção" (Überzeugung) e não se pode afirmar com segurança se os fundamentos de um juízo são subjetivos ou objetivos, por mais "persuadidos" que possamos estar pelo conhecimento que temos ${ }^{150}$. A postura crítica exige a passagem da persuasão à convicção, e o único modo de se afastar dos prejuízos que me levam ao erro é refletir.

Este sentido primeiro de reflexão enquanto "técnica da prevenção do prejuízo" 151 é aquele que está operando na idéia de Überlegung que encontramos na primeira crítica, onde agora seu aspecto metodológico será ressaltado de modo mais depurado e com novos contornos, o que permite que façamos uma avaliação mais profunda de sua proximidade com o empreendimento crítico como um todo. Entremos então no terreno da Crítica da Razão Pura a fim de buscar reconhecer como essa concepção programática de reflexão está ali em jogo e como ela se encontra ampliada e mais concretamente evocada.

A noção de reflexão nos é apresentada de maneira mais determinada no Apêndice à Analítica dos Princípios, cujo título é: "Da Anfibolia dos Conceitos da reflexão, resultante da confusão do uso empírico do Entendimento com o seu uso transcendental"

149 Nas diversas lógicas de Kant as fontes do erro (Inclinação, Imitação, Hábito, Egoísmo, Curiosidade, etc.) são consideradas como oriundas da sensibilidade, e a ilusão a que elas levam se relaciona a uma influência desta exercida tacitamente no entendimento: "Ein Vorurteil ist ein principium zu urtheilen aus subjectiven Ursachen, die für objective Gründe angesehen werden. Subjective Ursachen liegen alle in der Sinnlichkeit. Objective Gründe ligen im Verstande" VLo/Wiener, XXIV, p. 863. Ver também, KrV B77.

150 "Frequentemente a persuasão [Überredung] precede a convicção. A consciência que temos de muitos conhecimentos nossos não permite que possamos julgar se os fundamentos de nosso assentimento são objetivos ou subjetivos. De maneira que, para poder chegar à convicção a partir da mera persuasão, temos de, antes de mais nada, refletir [überlegen], isto é, ver a que faculdade de conhecimento um conhecimento pertence e, a seguir, investigar, isto é, comprovar se os fundamentos são suficientes ou insuficientes em relação ao objeto. Em muitos casos, permanecemos na persuasão; em alguns, chegamos à reflexão; em poucos, à investigação". Kant, Log, IX, p, 73.

${ }^{151}$ Heßbrüggen-Walter, op. cit. p. 155. 
152

Devemos nos ater, antes de tudo, ao lugar estratégico no qual essa noção nos é tematicamente apresentada. O próprio caráter de apêndice desse capítulo deve ser levado em conta na avaliação de seu estatuto no interior da arquitetônica da obra. Trata-se de um capítulo de passagem para a segunda grande secção da Lógica Transcendental, a Dialética Transcendental, na qual, após a Analítica Transcendental haver examinado exaustivamente o entendimento puro, "a terra da verdade" conforme a expressão de Kant, e ter ali "fixado a cada coisa o seu lugar próprio" (KrV, B295), deve-se passar agora ao perigoso oceano que rodeia essa ilha em direção ao qual a razão realiza uma busca inevitável por terras sempre ilusórias com as quais não de deixa se fascinar. É, pois, no interior da passagem da "lógica da verdade" à "lógica da aparência" 153 que a noção de reflexão receberá sua explicitação. Não se surpreenderá com essa sua posição aquele que mantiver em vista que o empreendimento crítico tematiza a reflexividade, a partir da qual ele se constitui, tendo como pano de fundo os enganos e as ilusões a que a razão está submetida.

Enquanto apêndice, seu caráter é análogo ao apêndice à Dialética Transcendental acerca "do uso regulativo das idéias da razão", o que indica que, em ambos os casos, não se trata de uma parte constitutiva da Analítica ou da Dialética Transcendental, mas tem como meta esclarecer os aspectos relativos ao uso que se pode fazer dos conceitos e princípios que as duas seções da Lógica Transcendental apresentam. Em ambos os apêndices não encontramos elementos que digam respeito à propriedade dos objetos conhecidos, e nem elementos que sejam implicados de maneira analítica no pensamento desses objetos, isto é, enquanto estruturas necessárias da autoconsciência, mas apenas uma orientação de como proceder com eles, relativo ao uso que deles podemos fazer.

Essa condição de átrio da Dialética explica, num primeiro nível, o termo “confusão" (Verwechselung) que aparece no título do primeiro apêndice; trata-se, pois, de uma confusão do uso empírico com o uso transcendental de conceitos da reflexão ${ }^{154}$, confusão que caracteriza também os enganos da razão em sua dialética (seus

152 Abordaremos em seguida o lugar estratégico da Anfibolia na qual a reflexão nos é apresentada. Seu lugar revela em muito o sentido dela no interior da Crítica.

${ }^{153}$ Kant, KrV, B87 e B349. Cf. Reuter, P., p. 14.

154 Abordaremos logo abaixo o que Kant denomina de "conceitos da reflexão" (Reflexionsbegriffe). 
paralogismo, antinomias) na qual a razão se vê necessariamente enredada. Devemos, pois, compreender o sentido da apresentação da reflexão (em seus diferentes níveis) ali onde se trata dessa confusão particular, que se caracteriza aqui enquanto anfibolia (Amphibolie). Uma caracterização mais próxima do texto do apêndice permitirá que entendamos qual é exatamente o sentido dessa confusão e a função da reflexão que a ela diretamente se liga.

O Apêndice começa com uma primeira definição da reflexão:

“A reflexão [Überlegung] (reflexio) não tem que ver com os objetos eles mesmos, para deles receber diretamente conceitos, mas é o estado de espírito [Zustand des Gemütes] em que, antes de mais, nos dispomos a descobrir as condições subjetivas pelas quais podemos chegar a conceitos. É a consciência da relação das representações dadas às nossas diferentes fontes do conhecimento, unicamente pela qual pode ser determinada corretamente a relação entre elas" (KrV, B316).

Kant está nos apresentando um sentido geral e ainda indeterminado de reflexão. Esse sentido permanece, no entanto, ainda pouco claro nesta demarcação inicial no que se refere ao papel da reflexão em relação à confusão anfibólica. E o objetivo principal deste apêndice é o de clarificar a operação da reflexão e precisar essa relação a partir da qual ela recebe sua função.

Habituado ao sentido tradicional da reflexão presente nos trabalhos de lógica escolar, o leitor dos tratados clássicos de lógica poderia supor se tratar aqui daquela reflexão que está associada aos processos de formação conceitual sobre os quais Kant se debruça nas Logikvorlesungen. Nestas, além da tematização da reflexão enquanto ação exigida para a prevenção de prejuízos, que acabamos de abordar, a reflexão é também apresentada em uma outra chave, relacionada diretamente à Begriffsbildung, como constituindo um de seus momentos fundamentais, ao lado dos atos de comparação e de abstração. Na Lógica editada por Jäsche lemos:

"Para fazer conceitos a partir de representações é preciso, portanto, poder comparar, refletir e abstrair, pois essas três operações lógicas do entendimento são as condições essenciais e universais da produção de todo conceito como tal" (Log, IX, p. 94). 
Essas três operações do entendimentos, que não devem ser tomadas como ocorrendo numa simples ordem cronológica - como o texto kantiano facilmente permite confundir, especialmente a partir do exemplo da formação do conceito de árvore ${ }^{155}$-, mas sim como atos simultâneos nessa atividade de formação ${ }^{156}$, dizem respeito, fundamentalmente, aos processos de universalização na apreensão conceitual e são ali abordados em direta relação com a tradição da escola de Wolff, através das obras de Baumgarten e de Meier ${ }^{157}$. De maneira geral, estes atos explicitam a ação de inscrição de representações sensíveis em conceitos gerais, a subsunção de representações singulares a conceitos universais. Através da "reflexão [Überlegung] sobre como representações diversas podem ser concebidas numa consciência", da comparação (Comparation/Vergleichung) "das representações entre elas, na sua relação com a unidade da consciência" e da abstração (Abstraction) ou "separação [Absonderung] de tudo o mais em que as representações dadas se distinguem” (Log, IX, p. 94) obtêm-se conceitos universais nos quais as marcas comuns às representações sensíveis estão refletidas. "Uma representação que como marca se torna universal através da consciência, chama-se conceito" (Rx 3057, XVI, p. 634). Trata-se aqui, pois, da origem lógica dos conceitos na operação de julgar: "uma representação comum a muitos objetos (conceptus communis) surge como a forma exigida pela faculdade de julgar" ${ }^{158}$. Essa reflexão é, pois, aquela que encontramos em jogo na formação das categorias do entendimento que, precisamente por esse motivo, são chamadas de "conceitos refletidos" (reflektierte Begriffe) em oposição aos conceitos da razão que são "inferidos"

155 "Vejo, por exemplo, um pinheiro, um salgueiro e uma tília. Na medida em que comparo inicialmente esses objetos entre eles, noto que são diferentes entre si em relação ao tronco, aos ramos, às folhas, etc. Mas se em seguida reflito unicamente sobre o que eles tem em comum, o troncos, os ramos, as próprias folhas, etc., e faço uma abstração de seu tamanho, de sua figura, etc., obtenho assim um conceito de árvore”. Log, IX, pp. 94-5.

156 "Reflection and Abstraction are not operations that follow comparison and are dependent on it; rather each depends on the others and all proceed simultaneously", Longuenesse, B, Kant and the Capacity to Judge, p. 116.

${ }^{157}$ Sobre as influências na formação do conceito de reflexão em Kant, conferir Liedtke, M. Der Begriff der Reflexion bei Kant, (1966).

${ }^{158}$ Log, IX, p. 94. Uma vez que aquilo que caracteriza a conceptualidade é precisamente a relação mediatizada (discursiva) a um objeto através de uma característica comum a muitos objetos, a expressão conceptus communis é em si mesma uma tautologia. Cf. Kant, Rx 2866, XVI, p. 552. 
(geschlossene Begriffe) e não mantém essa relação com a intuição ${ }^{159}$. Os conceitos do entendimento são, portanto, produtos dessas operações descritas na lógica, "eles nada contém senão a unidade da reflexão sobre os fenômenos" (Einheit der Reflexion über die Erscheinung) ${ }^{160}$.

Esse caráter reflexivo de todos os conceitos do entendimento não manifesta outra coisa do que a discursividade própria do entendimento e o caráter mediato das representações que ele produz. Podemos a partir disso dizer com A. Grandjean que "a reflexão é precisamente esse retorno que é todo conceito, elemento de um conhecimento discursivo ou reflexionante no sentido estrito" ${ }^{\prime 161}$.

Contudo, muito embora seja possível estabelecer um elo entre alguns aspectos do ato de reflexão envolvido na formação de conceitos e as modalidades de reflexão apresentadas no capítulo da Anfibolia - esforço a que se dedica, por exemplo, o trabalho de B. Longuenesse ${ }^{162}$, buscando demonstrar como a reflexão lógica e transcendental participam da dedução metafísica das categorias enquanto seu fio condutor (forma lógica dos juízos) ${ }^{163}$-, um tal viés de leitura facilmente perde de vista o problema maior da

${ }^{159} \mathrm{KrV}, \mathrm{B} 366$. "Alle reine Vernunftideen sind ideen der reflexion (discursivae und nicht intuitus, wie plato behauptete)" (Rx 3971, XVII, p. 342).

${ }^{160} \mathrm{KrV}$, B367. "Alle Begriffe überhaupt, von woher sie auch ihren Stoff nehmen mögen, sind reflektierte, d. i. in das logische Verhältnis der Vielgültigkeit Gebrachte Vorstelungen". Rx 5051, XVIII, p. 73. Cf. também, Lebrun, G. Kant e o fim da Metafisica, p. 376.

${ }^{161}$ Grandjean, A, Critique et Reflexion, p. 79.

162 Trata-se de um ponto controverso na interpretação do texto kantiano. B. Longuenesse (Kant and the Capacity to Judge) busca compreender a reflexão apresentada na anfibolia como sendo a mesma que está na base da dedução transcendental (cf, p. 115). Da opinião contrária é Heßbrüggen-Walter, op cit, p. 158; Marques, op. cit, p. 79 , Reuters, P. op. cit, pp. 107-108. . Como pretendemos mostrar, não negamos que haja uma relação entre aquilo que Kant chama de reflexão transcendental e a reflexão como momento na formação dos conceitos. Apenas indicamos que compreender essa reflexão a partir de sua função na formação de conceitos é perder de vista o caráter metodológico central que está em jogo na noção de reflexão na Anfibolia.

163 Apresentaremos essa distinção de modalidades da reflexão (lógica e transcendental) logo abaixo. Indicamos aqui, apenas, como uma leitura como a de Longuenesse tende a aproximar ambas as formas de reflexão diferenciadas por Kant na Anfibolia, nelas reconhecendo, através do ato comum da comparação (Vergleichung) o processo de formação de conceitos. Cf. Longuenesse, B. Kant and the Capacity to Judge, p. 115 e 252-53. "In other words, I want to argue that a correlation that was self-evident for Kant has been unduly neglected by commentators, at the cost of obscuring an essential element of his theory of cognition: the correlation between the logical comparison (of concepts), described in the Amphiboly chapter, and the operation of comparison accompanying those of reflection and abstraction through which concepts are generated in the first place, described in the Logic", p. 115. 
reflexão transcendental em sua função metodológica que deve ser compreendida como sendo de inteiramente outra ordem e amplitude ${ }^{164}$. Essa "reflexão metodológica" ${ }^{165}$ ali em questão tem pois em vista não "os próprios objetos para deles receber diretamente conceitos" - e não é por acaso que Kant abra o capítulo com essa advertência e o cuidado de indicar se tratar de "gegebene Vorstelungen", e não da formação destas -, mas a própria explicitação e legitimação da distinção crítica entre sensibilidade $e$ entendimento. Portanto, toda compreensão do caráter metodológico da reflexão no fazer crítico, conforme ela nos é apresentada nesse apêndice, depende da correta distinção entre as diversas modalidades da reflexão e a sua não confusão com a reflexão que participa da formação de conceitos, da qual a Logik nos fala.

Assim, além de nos distanciar da temática particular de formação de conceitos, a primeira definição geral da reflexão no capítulo da Anfibolia ainda nos diz mais. Não ter a ver com os objetos é apresentar a reflexão como não tendo uma função constitutiva no conhecimento, e, portanto, diferenciando-a dos atos constitutivos da síntese objetiva apresentados na primeira parte da Lógica Transcendental, justificando assim o estatuto de apêndice desse capítulo. Esse caráter não constitutivo da reflexão é um ponto central no qual se reúnem todas as modalidades de reflexão que aparecem na obra de Kant, e que será o núcleo da censura que Hegel lhe faz. Pois reconhecer o caráter metodológico da reflexão e recusá-la como constitutiva do conhecimento é, segundo Hegel, considerá-la apenas em seu aspecto negativo, despotencializado.

Dessa primeira determinação negativa da reflexão, Kant passa logo em seguida a uma determinação positiva: a reflexão, escreve Kant, é "o estado de espírito [Zustand des Gemütes] em que nos dispomos a descobrir as condições subjetivas pelas quais podemos chegar a conceitos". Estado de espírito, entendamos: não se trata aqui de um estado

164 "Entretanto será oportuna a seguinte advertência: nao é conveniente e tem mesmo consequencias perniciosas para a compreensão do que seja a atividade crítica da filosofia, numa inspiração kantiana, identificar a reflexão que estará na base da dedução das categorias a partir das formas lógicas do juízo com a reflexão transcendental a que nos referimos”. Marques, A. $A$ Razão Judicativa, p.79.

${ }^{165} \mathrm{O}$ termo é de G. Lebrun (Kant e o fim..., p. 377), que já tem em vista nessa denominação as conseqüências da ampliação do papel da reflexão a partir da apresentação do juízo reflexionante na $3^{\text {a }}$ Crítica. Empregamos aqui o mesmo termo, todavia, para indicar a função que o refletir em geral, e a reflexão transcendental em particular, possuem na "metodologia filosófica" da obra kantiana, já na $1^{a}$ Crítica. Cf. Reuter, P. Kants Theorie der Reflexionsbegriffe, pp. 108-9. Abordaremos esse ponto ao final desse capítulo. 
enquanto mera situação ou estado passivo da consciência; deve-se compreender "estado" em seu sentido ativo, como de uma ação (Handlung), o que o próprio termo alemão überlegen revela. Ter isso como horizonte é de fundamental importância, pois se trata de um estado em que nos dispomos (uns anschicken), ou seja, uma ação de reflexão, exigida pela postura crítica, pela qual nos voltamos às condições subjetivas que legitimam um determinado conceito (sua origem) e a relação na qual ele é pensado (juízo). Esse movimento de retorno da consciência às condições daquilo que pensa é, como escreve Kant, "um dever do qual ninguém pode dispensar-se se quiser julgar a priori sobre as coisas" ${ }^{166}$, isto é, se não quiser proceder como o dogmatismo pré-crítico.

Vemos, então, que nos encontrarmos bastante próximos daquilo que Kant, associando à tarefa crítica em geral, nos apresentava como sendo o que caracteriza a própria noção de transcendental inaugurada pela Kritik. "Chamo transcendental, escreve Kant, a todo o conhecimento que se ocupa menos dos objetos, que do nosso modo de os conhecer, na medida em que este deve ser possível a priori” ( $\mathrm{KrV}, \mathrm{B} 25)$. Aquilo que poderíamos dizer que caracteriza a postura crítica, é esse retorno a si em busca das “condições subjetivas do conhecimento" e esta característica da reflexão como retorno a si, que já se expressa no seu próprio termo, tomado de empréstimo do modelo de reflexão da luz, é um aspecto que está presente em toda a sua diversidade semântica na Oeuvre de Kant ${ }^{167}$, muito embora a especificidade desse retorno varie conforme a modalidade de reflexão de que se trata.

Mas é a segunda parte desta frase inicial do capitulo da Anfibolia que especifica o teor transcendental desse retorno em jogo na reflexão: trata-se da "consciência da relação das representações dadas às nossas diferentes fontes do conhecimento, unicamente pela qual pode ser determinada corretamente a relação entre elas" (KrV, B 316). Kant referese aqui às duas fontes de conhecimento, isto é, às próprias faculdades do espírito, sensibilidade e entendimento, de onde procede todo conhecimento possível. Todo o esforço crítico se organiza no sentido de denunciar os erros que derivam da não correta distinção entre essas faculdades (“distinção transcendental”), assim como entre seus diferentes "objetos", isto é, os fenômenos enquanto manifestações submetidas à

\footnotetext{
${ }^{166} \mathrm{KrV}, \mathrm{B} 319$.

${ }^{167}$ Cf. Reuter, P, op. cit., p. 84.
} 
sensibilidade e as coisas em si, enquanto seres do entendimento (Verstandeswesen), meramente pensadas por esse, mas que não podem ser objeto de uma intuição sensível 168. A ausência desta distinção crítica leva inevitavelmente ao erro em relação ao uso (Gebrauch) das categorias do entendimento, o qual, sem levar em consideração a aplicabilidade à experiência possível, pensa os objetos a partir da mera possibilidade lógica, não contraditória, expressa nas categorias, sem questionar assim a sua "validade objetiva", que depende da possibilidade de sua aplicação aos objetos da intuição ${ }^{169}$. Ou seja, a distinção exigida pela Crítica visa denunciar a

"ilusão de tomar a possibilidade lógica do conceito (já que ele não contradiz a si próprio) pela possibilidade transcendental das coisas (em que ao conceito corresponde um objeto) [que] só pode enganar e satisfazer pessoas inexperientes" (KrV, B302).

A determinação correta do valor objetivo de um juízo (ligação de representações na unidade da transcendental da apercepção) ${ }^{170}$ depende, portanto, dessa distinção crítica para que através da reflexão se possa discriminar adequadamente o modo com que essas representações se conectam; pois "a diferença destas faculdades [Sensibilidade e Entendimento] constitui uma grande diferença no modo como se devam pensar os conceitos" (KrV, B317).

A reflexão está assim ligada a uma questão fundamental que percorre o horizonte maior da filosofia crítica, e que nesse apêndice é expressa de maneira um tanto confusa, o que leva facilmente a mal-entendidos e demanda uma correta interpretação. Kant escreve:

"A primeira questão que se levanta antes de todo posterior tratamento das nossas representações é a seguinte: A que faculdade de conhecimento elas pertencem em conjunto [zusammengehören]? É o entendimento ou os sentidos aquilo ante o qual [vor denen] elas são ligadas ou comparadas?" (KrV, B316)

\footnotetext{
${ }^{168}$ Trata-se do conceito negativo de noumeno, definido como "uma coisa, na medida em que não é objeto de nossa intuição". KrV, B307

${ }^{169}$ Cf. KrV A253.

170 "Só assim dessa relação surge um juízo, ou seja uma relação que seja objetivamente válida, e que se distinga suficientemente de uma relação destas mesmas representações, na qual há validade apenas subjetiva..." KrV, B142
} 
Parece que Kant está aqui a tratar a reflexão no exato mesmo sentido em que falava de crítica - proximidade esta que se revela na pergunta pela origem (Ursprung) e sede (Sitz) dos conceitos, em nome de sua validação objetiva, uma pergunta fundamental que a crítica instaura a partir da distinção capital entre fenômeno e coisa-em-si.

Todavia essa questão não deixa de causar estranheza ao leitor da primeira parte da Crítica da Razão Pura: não havia Kant apresentado de maneira insistente como tese central o fato de que toda ação de ligação é sempre um ato do entendimento e que o conhecimento é apenas possível a partir da união da sensibilidade com o entendimento? A partir da pergunta maior enunciada nesse apêndice, o leitor poderia, incorretamente, ter a sensação de que Kant estaria afirmando haver a possibilidade de uma ligação de representações unicamente pela sensibilidade, o que arruinaria todas as distinções críticas feitas na primeira parte da obra de 1781. É justamente a correta compreensão do sentido dessa pergunta que permite que entendamos em que reside a confusão anfibólica e como exatamente a reflexão age para evitar a mesma. Para isso devemos nos voltar ao significado apropriado da expressão "pertencer à faculdade do conhecimento", articulada na pergunta pela faculdade ante a qual as representações são ligadas, caminho que será a chave para o entendimento daquilo que Kant chama de Tópica Transcendental - doutrina central em torno do qual se organiza o apêndice e que situa o papel da reflexão.

Antes de o fazermos, apenas uma indicação importante para nossos propósitos: não podemos deixar passar despercebido que essa maneira um tanto incerta de apresentar a reflexão não deixa de ser um indício daquela tensão que mencionamos no início e que temos de tornar mais explicita na segunda parte desse capítulo. Se por um lado a reflexão está intrinsecamente associada ao empreendimento crítico como um todo, e participa do regime geral da distinção transcendental entre as faculdades do conhecimento e entre os fenômenos e as coisas em si, há, por outro lado, no interior dessa figura denominada de reflexão, um aspecto que parece caminhar em direção à mediação destes dois grandes "troncos do conhecimento humano" (KrV, B29) que a distinção crítica cindira de maneira tão radical. Esse aspecto de mediação, que marcha no sentido de uma ampliação dos limites do conhecimento será um dos pontos centrais do 
aprofundamento da reflexão realizado pela reinterpretação especulativa realizada por Hegel ${ }^{171}$.

Voltemos, pois, à pergunta colocada deixando por um momento em suspenso o sentido desse "pertencer" que logo se esclarecerá. Tal pergunta no exame das representações (“A que poder de conhecimento elas pertencem em conjunto? É o entendimento ou os sentidos aquilo ante o qual elas são ligadas ou comparadas?") é, como vimos, uma exigência que se coloca ao filósofo crítico, pois a não clara consciência dessa ligação de representações (juízo) faz com que confundamos o seu uso lícito com um uso não imanente e não legitimo, tomando por objetivo, isto é, tomando um juízo que tem um uso meramente lógico como dizendo respeito aos objetos, às coisas (valor transcendental).

É importante ter-se aqui em vista que o termo representação (Vorstellung) empregado por Kant possui um duplo sentido, referindo-se ora a conceitos (originados pelo entendimento), ora a intuições (originados na sensibilidade) e é nessa sua ambigüidade que se expressa a própria necessidade da tarefa crítica. Por representação não podemos entender apenas conceitos produzidos pelo entendimento, como concebia uma filosofia intelectualista como a de Leibniz, que não por acaso será o alvo das acusações desse Apêndice; mas representações podem também ser intuições, isto é, ter sua origem na sensibilidade, sendo que essa não será mais considerada simplesmente como uma forma de representação intelectual confusa ${ }^{172}$. Nesse sentido, o retorno das representações às faculdades do conhecimento - a reflexão -, surge como exigência a partir da distinção transcendental efetuada pela crítica e tem como horizonte em sua operação a ambigüidade inscrita na noção de representação.

Aqui se apresenta o sentido geral desse Amphi (Amphibolie), desse "entre" a sensibilidade e o entendimento no qual se encontra a consciência quando reflete sobre suas representações. No entanto, a confusão a que esse capítulo se volta se refere mais

${ }^{171}$ Cf. Dottori, Die Reflexion des Wirchlichen, pp. 63-64: "É claro que a reflexão assume uma posição decisiva no interior da possibilidade do conhecimento, que consiste - como Hegel irá se expressar posteriormente - em mediar a sensibilidade e o entendimento. Por essa razão a reflexão é igualada ao momento dialético do pensamento (negativo-racional), para com isso deixar o espaço novamente aberto para o conhecimento de essência. Certamente essa é a tarefa que Hegel irá colocar à reflexão, e não aquela que foi pensada por Kant ".

${ }^{172} \mathrm{Cf} . \mathrm{KrV}, \mathrm{B} 61-2$ e B327. 
precisamente à duplicidade de sentido dos conceitos que a reflexão utiliza para realizar essa comparação. Para sua ação, a reflexão opera com conceitos chamados por Kant de Reflexionsbegriffe, que são propriamente conceitos de comparação (conceptus comarationis), e que assim como os conceitos do entendimento, as categorias, possuem uma dupla possibilidade de uso, que vária conforme o "objeto" ao qual é aplicado. Os conceitos da reflexão são apresentados em quatro pares: Unidade e Diversidade (Einerleiheit und Verschiedenheit), Concordância e Oposição (Einstimmung und Widerstreit), Interno e Externo (Inneres und Äußeres) e Matéria e Forma (Materie und Form). Eles são conceitos através dos quais comparamos representações antes de qualquer juízo objetivo e diferem das categorias do entendimento na medida em que "não representam o objeto segundo o que constitui o seu conceito (grandeza, realidade), mas somente, em toda a sua diversidade, a comparação das representações que precedem o conceito das coisas" ( $\mathrm{KrV}, \mathrm{B} 325)$. Por esse motivo são chamados de conceitos da reflexão, indicando não possuírem um caráter constitutivo no conhecimento de um objeto, mas que apenas são operados pela reflexão na comparação entre conceitos.

Isso quer dizer que os conceitos da reflexão - que são os mesmos conceitos tradicionais da ontologia clássica desde os antigos até os modernos (Leibniz e Wolff) são dissecados de seu caráter ontológico e rebaixados na filosofia crítica a conceitos funcionais de comparação de representações. Nada mais afirmam de constitutivo acerca do que as coisas são, mas apenas permitem comparar as representações, sejam elas conceitos do entendimento puro ou objetos da intuição. Como pretendemos mostrar ao final desse capítulo, será essa deficiência da reflexão, seu caráter meramente comparativo e não constitutivo, que se configurará como um dos alvos principais da crítica de Hegel, para o qual a reflexão deverá recuperar seu valor cognitivo, de forma que o aprofundamento da reflexão a que nos referimos poderia ser enunciado como a alteração do próprio estatuto da reflexão: de uma comparação de representações em vista da legitimação de juízos epistemológicos, ela passa a uma "reflexão ontológica" ${ }^{173}$.

Podemos assim compreender melhor o sentido da expressão "confusão entre uso empírico do entendimento com o seu uso transcendental", a que Kant chama de Anfibolia. Essa diz respeito, portanto, a uma ambigüidade inscrita nos conceitos da

${ }^{173}$ Cf. Dottori, R, op. cit., pp. 73, 93. 
reflexão, nos quais permanece indeterminado o domínio no qual seu emprego pode ser realizado. É precisamente por reconhecer essa ambigüidade de uso dos conceitos da reflexão que a comparação das representações não pode permanecer no nível meramente lógico, ou seja, comparar sem levar em conta o "lugar" em que tal comparação se dá.

"Poder-se-ia dizer que a reflexão lógica é uma mera comparação, pois nela se abstrai completamente da faculdade de conhecimento a que pertencem as representações dadas, sendo portanto tratadas como homogêneas no que respeita ao seu lugar no espírito [Gemüt]" (KrV, B318).

Refletir apenas logicamente é realizar uma comparação das representações apenas no que se refere à forma do juízo, fazendo uma "abstração de toda diferença real ou objetiva do conhecimento", não se ocupando com o seu conteúdo ${ }^{174}$.

Como, porém, a filosofia transcendental não se satisfaz com uma lógica formal que abstraia do conteúdo dos juízos e dos conceitos - e que enuncie leis que digam respeito apenas ao entendimento puro e não aos objetos da natureza ${ }^{175}$ - uma comparação lógica dos conceitos não é suficiente para determinar se as próprias coisas, isto é, aquelas que necessariamente mantêm uma relação dupla com a sensibilidade e com o entendimento, são a mesma ou distintas, concordantes ou discordantes (etc.). Uma comparação lógica dos conceitos não é suficiente para determinar a relação entre as próprias coisas comparadas: é necessária uma ação que determine a maneira com que essas coisas devem se articular com as faculdades de conhecimento, e a partir disso, determinar a relação que as representações mantêm entre si. Isso significa que a determinação da relação entre as representações depende, para que se tenha segurança acerca daquilo que se está afirmando em um juízo, de uma reflexão que não se restrinja à mera comparação de conceitos no sentido lógico formal (reflexão lógica), mas que realize

\footnotetext{
174 “\$19 - Objeto da reflexão lógica é a mera forma dos juízos: Como a lógica abstrai de toda diferença real ou objetiva do conhecimento, a Lógica não pode se ocupar nem da matéria dos juízos, assim como nem do conteúdo dos conceitos. Ela deve, portanto, investigar unicamente a diferença dos juízos no que concerne a sua mera forma". Log, IX, p. 101.

${ }^{175}$ A distinção entre reflexão lógica e reflexão transcendental espelha, nesse sentido, aquela entre lógica geral e lógica transcendental, indicada por Kant no início da segunda parte da Crítica da Razão Pura. Cf. KrV, B74-82.
} 
simultaneamente uma discriminação das faculdades de conhecimento a que esses conceitos pertencem, isto é, de uma reflexão transcendental.

Kant define a reflexão transcendental como:

"o ato [Handlung] pelo qual eu confronto a comparação das representações em geral com a faculdade do conhecimento, onde aquela se realiza, e pelo qual distingo se elas são comparadas entre si como pertencentes ao entendimento puro ou à intuição sensível" (KrV, B317).

Confrontar significa aqui "manter junto" (zusammenhalten), e diz respeito a uma aproximação não apenas de duas representações que se ligam em um juízo, mas da própria comparação das representações com a faculdade do conhecimento em que tal ligação se institui. É por isso que Kant, contrapondo à reflexão lógica, que é uma "mera comparação de representações", afirma que apenas a reflexão transcendental "contém o princípio da possibilidade da comparação objetiva das representações entre si” ( $\mathrm{KrV}$, B319). Apenas a reflexão transcendental permite, portanto, avaliar o sentido de um juizo, pois diferentemente da reflexão lógica, não mantém indeterminado a referência ao conteúdo dos conceitos que se ligam, e a unidade ou diversidade, a concordância ou oposição que se afirma refere-se às próprias coisas que o juízo objetivo enuncia. Nesse sentido a reflexão transcendental tem a função absolutamente fundamental para o projeto crítico de legitimar ou recusar a passagem do conceito aos objetos de que são conceitos 176 .

É nesse sentido que Kant pode afirmar que a reflexão transcendental é um dever para o filósofo crítico, pois apenas ela pode garantir a segurança em relação ao uso que se faz de algum conceito e evitar que se tome por um princípio sintético aquilo que tem valor apenas na esfera do entendimento puro. Esse descuido quanto ao uso dos conceitos era inevitável a uma filosofia intelectualista como a de Leibniz que procedia na formulação de princípios pretensamente sintéticos, isto é, válido para as coisas como objetos dos sentidos, sem a realização prévia de uma crítica da razão, ou seja, sem a correta distinção das faculdades de conhecimento e da diferença fundamental dela resultante entre fenômeno e coisa em si. Para um filósofo que "intelectualizou os

${ }^{176} \mathrm{Cf} . \mathrm{KrV}, \mathrm{B} 325$. 
fenômenos” (KrV, B326-7), para quem, portanto, não vigora a distinção transcendental crítica, a comparação entre representações (reflexão) não pode ser jamais transcendental, isto é, não leva em conta a faculdade de conhecimento em que se legitima tal relação, de modo que as ligações válidas apenas na esfera do entendimento são estendidas como válidas também para as coisas (fenômenos). "Leibniz comparava, pois, entre si, os objetos dos sentidos como coisas em geral, simplesmente no entendimento" (KrV, B327).

É o caso do princípio dos indiscerníveis que pretende legislar sobre as coisas enquanto objetos dos sentidos, estendendo a identidade lógica de duas representações do entendimento à identidade numérica de duas coisas, sem levar em consideração as determinações do espaço e do tempo a que apenas as últimas, enquanto fenômenos, estão submetidas ${ }^{177}$. A aplicação, aos objetos sentidos, do princípio dos indiscerníveis, que é legitimo apenas para os conceitos de coisas em geral, é um exemplo de uma anfibolia (dos conceitos da reflexão unidade e diversidade) que resulta num falso conhecimento da natureza. Esse alargamento (Erweiterung) para a natureza, como uma lei sua, de uma mera regra analítica ou da comparação das coisas mediante conceitos é a ilusão a que se cai necessariamente na ausência de uma discriminação da faculdade de conhecimento a que as representações pertencem em conjunto.

Voltamos assim ao termo "pertencer" que participa de todas as definições que Kant oferece da reflexão transcendental. Perguntávamos acima pelo sentido desse pertencimento uma vez que sua interpretação num "sentido possessivo" ${ }^{178}$ parecer ter de ser de imediato recusada, uma vez que uma das teses fundamentais da Crítica da Razão Pura é a de que somente é possível um conhecimento objetivo a partir da síntese de ambas as fontes do conhecimento. O que significaria, então, perguntar pela faculdade de conhecimento ante a qual uma ligação entre representações se dá? E, além disso, se um juízo é sempre a síntese de dois conceitos, e a produção de um conceito é sempre uma ação do entendimento, qual o sentido de perguntar pela origem de um conceito? ${ }^{179} \mathrm{~A}$ resposta para essas perguntas é fornecida pelo correto entendimento do sentido da Tópica Transcendental, uma doutrina que se mantém intimamente ligada à noção de crítica da

\footnotetext{
${ }^{177}$ Cf. KrV, B319-20 e 327-8.

${ }^{178}$ Reuters, P., op. cit, pp. 98-100

${ }^{179}$ Cf. Reuters, P., op. cit, p. 98 e Heßbrüggen-Walter, S, op cit, p.148-9.
} 
razão e que, nesse sentido, ilustra de maneira nítida a relação entre reflexão e crítica que pretendemos ressaltar.

Kant chama de "lugar transcendental" (transzendentaler Ort) "a posição [Stelle] que atribuímos a um conceito, seja na sensibilidade, seja no entendimento puro" (KrV, B324), e entende por isso, na esteira do sentido da tópica lógica de Aristóteles ${ }^{180}$, os títulos (conceitos) sob os quais outros conceitos e conhecimentos são pensados, isto é, pertencem. Esses Topoi são, portanto, títulos gerais a partir dos quais a disciplina chamada de Tópica pode desenvolver a argumentação e a legitimação do uso desses conceitos. A idéia de lugar (Ort) ou de sede (Sizt) deve, conseqüentemente, ser aqui compreendida a partir da idéia de tópica, significando o lugar de onde provém a as regras acerca do uso de um conceito e a conseqüente legitimação de uma determinada relação de representações (juizo). A Tópica transcendental, na medida em que leva em consideração a distinção transcendental das faculdades de conhecimento, é por isso definida como a doutrina que realiza "a determinação dessa posição que compete a cada conceito, conforme o seu uso e as regras que ensinam a determinar o lugar de todos os conceitos" (KrV, B324) ${ }^{181}$.

O lugar transcendental não deve, por conseguinte, ser identificado à faculdade que produziu tal conceito, o que caminharia antes na direção de uma confusão das faculdades do conhecimento, já que desde a Crítica da Razão Pura, não há mais sentido em se falar em "conceitos da sensibilidade". Produção de conceitos, como abordamos acima, é uma atividade exclusiva do entendimento, e portanto, a tarefa de atribuir uma posição (Stelle) a um conceito não diz respeito, propriamente entendido, a buscar sua sede de origem, enquanto faculdade que o produziu, mas sim de buscar o lugar em que esse conceito recebe a legitimação de seu uso. Importante ressaltar como nos encontramos aqui na mesma temática de validação epistemológica dos juízos de que os cursos de lógica falavam e na qual também era a Überlegung a ação exigida para esta. Agora, porém, a reflexão é incorporada em uma disciplina metodologicamente mais organizada e consistente. A tópica transcendental será então definida como sendo a "disciplina que é

\footnotetext{
${ }^{180}$ Cf. Heßbrüggen-Walter, S, op cit, p.147-150.

${ }^{181} \mathrm{O}$ grifo é de nossa autoria.
} 
dedicada ao estabelecimento desse uso segundo regras e que assim responde a pergunta pela fonte de legitimação para um juízo" ${ }^{182}$.

Vemos com isso como a tópica transcendental se apresenta como uma doutrina fundamental à tarefa da crítica, uma vez que apenas ela "nos preservaria das surpresas do entendimento puro e das ilusões [Blendwerken] daí resultantes, na medida em que sempre distinguiria a que faculdade de conhecimento pertenceriam propriamente os conceitos" 183. E a ação da reflexão (transcendental) é a operação capital que conduz à realização de uma tópica transcendental, ambas recebendo sentido a partir da distinção crítica à qual respondem. Podemos afirmar, portanto, que a Crítica opera enquanto reflexão, e depende dessa operação para realizar-se enquanto crítica. Não é por acaso que muitos leitores da $1^{\text {a }}$ Crítica tendem a praticamente identificar a operação da reflexão transcendental à Crítica da Razão Pura como um todo, compreendendo esta como uma forma de operação daquela ${ }^{184}$. Por outro lado, devemos também reconhecer que a reflexão é uma exigência da Kritik e opera em nome desta e a partir das distinções por ela previamente realizadas. De modo que sem a rígida distinção entre sensibilidade e entendimento desempenhada pela Crítica a reflexão não saberia como operar, pois em seu retorno não teria como determinar nem a procedência das representações nem a instância de legitimação de seu uso. É nesse sentido que podemos dizer que a reflexão kantiana é uma reflexão crítica, e apesar disso, que a reflexão não se identifica à Crítica como um todo, mas antes a pressupõe ${ }^{185}$. Essa distinção é fundamental para a compreensão da reinterpretação da reflexão que será realizada por Hegel. Pois se toda forma de reflexão estivesse necessariamente comprometida com os pressupostos críticos, não haveria nenhuma forma de aprofundamento possível que a transmutasse em uma forma positiva de conhecimento, em uma reflexão ontológica ou especulativa ${ }^{186}$.

Vemos assim como a reflexão, na multiplicidade de procedimentos que ela compreende, e em particular enquanto reflexão transcendental - é importante ressaltar

\footnotetext{
${ }^{182}$ Heßbrüggen-Walter, op cit, p. 150.

${ }^{183} \mathrm{KrV}, \mathrm{B} 324$.

184 "The whole Critique of pure reason may be regarded as a work of transcendental reflexion. It seeks to trace the origins of our concept to the different capacities and powers of human mind: and in this way it seeks to determinate the character of their supposed objects", H. J. Paton (1969), apud, Dottori, op. cit, p.38.

${ }^{185}$ Cf. Dottori, op. cit, p. 39

${ }^{186}$ Cf. Hegel, DS, p. 115.
} 
que a reflexão transcendental é a modalidade superior da reflexão que pressupõe as operações reflexivas inferiores ${ }^{187}$ - se mostra como sendo a instância fundamental da Crítica, e isto precisamente na medida em que se constitui como seu verdadeiro método ${ }^{188}$. Nesse sentido, o apêndice dedicado à anfibolia recebe o estatuto de um capítulo central da Critica da Razão Pura, no qual, como escreve H. Cohen, Kant "fornece uma apresentação autêntica de sua disposição metodológica" ${ }^{189}$, e traz à luz a "função metodológica" operada pela Überlegung no interior da tarefa crítica ${ }^{190}$. Como todo método, a reflexão responde aos pressupostos assumidos pela Crítica, o que não significa dizer que a própria reflexão deva ser necessariamente crítica, isto é, considerada no interior de seus contornos. Ao contrário a reflexão é o modus operandi central da Crítica, sem, todavia, se reduzir a ela. E é a sua não completa absorção que permite que a reflexão seja apreendida por um pensamento que já não seja mais o pensamento crítico, tarefa que a filosofia de Hegel assumirá a partir de Jena.

Devemos investigar agora em que medida a reflexão crítica permite entrever uma reflexão que atua na contramão do projeto que a erigiu, como que "contra a intenção de Kant" ${ }^{191}$.

\subsection{Para além da reflexão crítica}

ß) Em que medida a reflexão na filosofia kantiana, como instância fundamental do pensar crítico, carrega consigo a exigência de um aprofundamento e ultrapassamento?

Vimos na primeira parte deste capítulo como a idéia de reflexão aparece na obra de Kant desde os cursos de lógica associada a uma distância crítica necessária como

187 “A reflexão transcendental não reside, portanto, apenas em um fundamentalmente outro plano do discurso do que a reflexão empírica e a reflexão lógica, mas é sistematicamente anterior a essas formas de reflexão". Reuters, op. cit, p. 108.

${ }^{188}$ Cf. Lebrun, G. Kant e o fim da Metafísica, p.393.

${ }^{189}$ Cohen, H. Commentaire de la 'Critique de la raison pure', p. 149. "Sem dúvida, então, esta atividade [reflexão] é crucial numa filosofia que se pretenda crítica e não será demasiado arriscado pensar o capítulo ou apêndice onde é exposta como o capítulo central da primeira crítica", Marques, A. A Razão Judicativa, p. 81.

190 "A finalidade argumentativa do capitulo da Anfibolia não residiria, portanto, numa retomada das compreensões fundamentais da 'Crítica da Razão Pura' em contraposição a posições de filosofias pré-críticas (...), mas residiria em uma concepção de uma metodologia filosófica como lógica da filosofia". Reuters, P. op. cit, pp. 108-9.

${ }^{191}$ Cf. Hegel, VGPh, HW XX, p. 356. 
precaução em relação às diversas fontes de erro, caracterizando-se por ser a operação que garante segurança na validação epistemológica de juízos objetivos. Nesse sentido, a ação da reflexão estava associada à autonomia prática e cognitiva de uma razão esclarecida que reconhece e combate as fontes de erro e de engano que surgem em toda situação de passividade e heteronomia.

A confusão caracterizada como anfibolia, expressa no apêndice à Analítica Transcendental, referia-se a uma confusão do entendimento no que diz respeito ao uso empírico ou uso puro dos conceitos da reflexão, visto que o sentido da comparação das representações, realizadas por meio deles, somente podia ser corretamente determinado a partir de uma consciência da relação das representações com as fontes de conhecimentos ante as quais tal relação se legitima ou não como objetiva, ou seja, através de uma reflexão transcendental. Sem a atenção voltada às fontes do conhecimento, não há condições para uma "comparação objetiva" e segura das representações e a confusão anfibólica não pode ser evitada:

"O erro, que de modo mais especioso leva a este engano e pode ser desculpado, mas não justificado, consiste em que o uso do entendimento, contrariamente à sua determinação, se torna transcendental e os objetos, ou seja, as intuições possíveis, se regem pelos conceitos em vez dos conceitos pelas intuições possível (em que unicamente assenta a sua validade objetiva" (KrV, B345)

Contrariando assim sua determinação, os princípios do entendimento puro eram aplicados a objetos que não podem se apresentar em nenhuma experiência e, dessa forma, seu uso deixava de ser empírico e passava a ser transcendental. Tal confusão se revelava a raiz dos principais erros cometidos pelas filosofias intelectualistas, que tomadas pela "ilusão [Blendwerk] de uma extensão do entendimento puro" ( $\mathrm{KrV}, \mathrm{B} 352)$, não podiam descobrir e desmascarar a aparência transcendental originada em princípios transcendentes que ultrapassavam os limites da experiência possível, estando assim fadadas ao engano ${ }^{192}$.

\footnotetext{
192 Aqui devemos nos ater a uma distinção importante sem a qual facilmente confundimos aquilo que Kant chama de Anfibolia dos conceitos da reflexão com as "ilusões inevitáveis" da dialética da razão, em particular as antinomias. Apenas para essa segunda é que se pode falar propriamente em "transzendentaler Schein", pois essa aparência, não sendo meramente lógica, não pode
} 
A reflexão transcendental realiza, como vimos, uma comparação objetiva das representações em um juízo, buscando, através de uma tópica transcendental - que deve indicar as faculdades nas quais essa ligação poderia ser legitimada - saber em que sentido nele se fala de objeto (noumeno ou fenômeno), ou seja, "se é o entendimento puro que pensa essas representações, ou a sensibilidade que as dá no fenômeno" ( $\mathrm{KrV}, \mathrm{B} 325)$. Dessa forma o filósofo crítico pode evitar os enganos resultantes da aparência transcendental originada do uso não imanente das categorias do entendimento ou dos conceitos de reflexão. Vemos, assim, como a reflexão está nesse sentido diretamente vinculada ao reconhecimento da finitude do conhecimento, uma tese maior que percorre toda a filosofia crítica: conceitos são apenas dotados de sentido e significado em sua referência (em seu emprego) à sensibilidade, e para o conhecimento, os objetos do entendimento puro permanecem necessariamente transcendentes. Toda exigência de cautela repetidamente alertada pela Crítica surge a partir dessa finitude reconhecida, e a função da reflexão é justamente a de refrear as ilusões de um conhecimento que pretenda ultrapassar sua finitude. Nisso reside o aspecto negativo da reflexão.

Porém, embora a noção de reflexão apresentada na Anfibolia esteja ali sempre vinculada à noção de erro, ilusão e confusão, e venha à luz como exigência do filósofo crítico diante dessa confusão do entendimento, e que, portanto, os conceitos da reflexão ali abordados não tenham uma função constitutiva, pudemos já indicar como a reflexão em geral, não deixa de ter um papel importante no conhecimento. Essa função metacognitiva da reflexão se apresentava na importância que ela assumia na caracterização de um juízo enquanto provisório e seu aspecto heurístico, fundamental

desaparecer por completo através da crítica, mas apenas ser por ela desmascarada, visto se tratar de uma "dialética da razão pura natural e inevitável". (KrV, B350-54). No caso da Anfibolia, os erros ali apresentados assemelham-se mais aos Paralogismos da razão pura, uma vez que, assim como nesses, os erros podem ser a princípio corrigidos e evitados. Essa é a razão pela qual Kant afirma ser esse erro desculpável, mas não justificado, conforme o trecho acima citado. O que diferencia os erros expressos nos Paralogismos daqueles na Anfibolia é que estes últimos tem sua origem na confusão do uso do entendimento e não em uma conclusão ou inferência $(S \operatorname{chlu} \beta)$ da razão. Empregamos aqui, todavia, a noção de "aparência transcendental" para indicar como a reflexão transcendental é uma exigência para o filósofo crítico que não se restringe à correção dos erros da anfibolia, mas estende-se de modo geral para toda a dialética - tenha-se em vista que a antinomia referente ao conceito de mundo se origina precisamente da ambigüidade do conceito de "matéria transcendental", ora referida à realidade dada no espaço e no tempo, ora ao substrato transcendental que permanece vazio e desconhecido. A respeito da caracterização dos erros anfibólicos em contraposição às ilusões dialéticas, ver Reuters, P. op. cit., pp. 206-210. 
para a ciência, como isso já era indicado nos cursos de lógica. Sem um caráter constitutivo e determinante, a reflexão não deixava de ter sua importância do ponto de vista regulativo, algo que, como dissemos, se espelhava na correspondência entre ambos os apêndices (à Analítica Transcendental e à Dialética Transcendental) da $1^{\text {a }}$ Crítica. $\mathrm{O}$ processo de reflexão aparece como uma auto-regulação necessária ao conhecimento “todos os juízos necessitam de uma reflexão" (KrV, B317) - sem o qual ele perde sua orientação e legitimação.

Para que possamos agora tematizar essa função positiva da reflexão no conhecimento e, a partir disso, indicar como já em Kant a reflexão não se restringe somente à precaução crítica, devemos nos dirigir a essa sua função cognitiva na investigação da natureza e em sua implicação na reconfiguração do próprio domínio da experiência. Será especialmente na $3^{\mathrm{a}}$ Crítica, Kritik der Urteilskraft, que Kant desenvolverá o conceito de reflexão que já estava em germe desde a sua tematização acerca dos juízos provisórios e de sua importância, porém agora reconhecendo um novo estatuto para a faculdade de julgar e um novo papel da reflexão em relação ao conhecimento.

Compreenderemos essa nova inflexão da reflexão na obra kantiana se tivermos como horizonte a relação entre a especulação e a reflexão na filosofia de Kant. Com isso alcançaremos a condição de considerar em que sentido há uma positividade dessa reflexão e quais as deficiências que ela ainda conserva em relação ao conhecimento, indicando, desse modo, simultaneamente sua potência e impotência, tensão que será reconhecida por Hegel como uma exigência de aprofundamento e ultrapassamento. Importante enfatizar que reflexão e especulação são os dois conceitos maiores que serão reinterpretados na primeira filosofia de Hegel a partir de uma contraposição com a interpretação que possuem na filosofia kantiana ${ }^{193}$.

Kant apresenta uma definição do conhecimento especulativo no interior da última seção da dialética transcendental, destinado a criticar uma teologia fundada em princípios especulativos da razão:

"Um conhecimento teórico é especulativo quando se reporta a um objeto ou a conceitos de um objeto, que em

${ }^{193}$ Cf. Hegel, DS, p. 41. 
experiência alguma se podem alcançar. Opõe-se ao conhecimento natural, que não se dirige a nenhum outro objeto ou predicado desse, senão àqueles que podem ser dados em uma experiência possível " (KrV, B662-63).

Dentro dessa classe de conhecimentos teórico-especulativo encontramos todas aquelas ambições da razão em pensar um objeto para além do que pode ser dado na experiência. Kant denomina esse uso da razão, que a partir de alguma coisa existente no mundo infere sua causa não condicionada, de "uso especulativo" da razão, em oposição ao seu "uso natural" voltado ao conhecimento da natureza, e no qual o princípio de causalidade tem valor objetivo, uma vez que permanece no âmbito do que é condicionado, ou seja, nos limites da experiência. O uso especulativo da razão, no entanto, responde a um "interesse especulativo da razão", a saber, o de fornecer universalidade e sistematicidade ao conhecimento ${ }^{194}$. Uma vez que o conhecimento natural é sempre voltado aos objetos da experiência, que enquanto tais são necessariamente condicionados, é da própria natureza da razão fornecer um conceito que dê conta da totalidade absoluta de condições desses objetos, de forma a "prescrever a orientação para uma certa unidade" ao entendimento ( $\mathrm{KrV}, \mathrm{B} 383)$. Esses conceitos da razão pura são chamados por Kant de Idéias e estão, dessa forma, "fundados na natureza da razão" (KrV B380), uma vez que são produtos de uma "exigência da razão". Na medida em que as idéias se referem à síntese absoluta das condições de um condicionado, esses conceitos devem necessariamente ser, por sua vez, incondicionados e não podem ser dados em nenhuma experiência - "pois nenhuma experiência é incondicionada" (KrV, B383), de modo que nenhum objeto pode ser adequado a um conceito da razão. Temos como exemplo de um uso especulativo da razão a teologia especulativa que, seguindo o argumento ontológico da prova de Deus, pretende afirmar a existência do Ser supremo a partir de seu mero conceito, sem sua relação com a experiência. Para a razão especulativa, a Crítica exige que desse Ser supremo seja apenas afirmado seu caráter de ideal, cuja realidade objetiva não pode ser nem provada nem refutada. "Todas as tentativas de um uso meramente especulativo da razão com respeito à teologia são completamente infrutíferas e, segundo sua índole interna, nulas e vãs” (KrV, B664).

${ }^{194}$ Cf. KrV, B 704. 
A especulação surge, pois, sempre que a razão quer pensar o todo da experiência, e é através das idéias que ela chega a um princípio de unidade sistemática para o conhecimento. É devido a esse interesse da razão em conservar a maior unidade sistemática no conhecimento, que a razão é também levada à sua dialética própria, pois embora as idéias não sejam em si mesmas dialéticas, a razão reivindica o direito de realizá-las ${ }^{195}$; e é tanto na "má-compreensão" (Mißverstand) do que significa a realização de uma idéia, quanto na "imprudência" (Unbehutsamkeit) em relação ao uso das mesma que reside os abusos que a Crítica pretende denunciar. Assim como no capítulo da Anfibolia a prudência crítica exigia que se perguntasse pelo uso correto dos conceitos da reflexão, no Apêndice à Dialética Transcendental o filósofo se voltará à cautela necessária para o uso legitimo que se pode fazer das idéias da razão. O que está em jogo aqui é, portanto, a consideração dos limites da especulação e a indicação de até que ponto a mesma pode ter uma atuação positiva para o conhecimento.

Vemos através desta idéia de limitação da especulação - e vale lembrar que a Crítica da Razão Pura é chamada por Kant de "tribunal supremo de todos os direitos e pretensões de nossa especulação" ( $\mathrm{KrV}$, B697) - como se configura no âmbito crítico esse aspecto negativo da reflexão. Poder-se-ia afirmar, nesse sentido, que a reflexão transcendental deve restringir uma pretensão, equivocada, da razão especulativa; $a$ reflexão deve, portanto, indicar os limites à especulação. É verdade que desde o prefácio à segunda edição da Crítica da Razão Pura toda forma de restrição do erro já era indicada como possuindo um aspecto positivo ${ }^{196}$ e que poderíamos por isso afirmar uma positividade indireta da reflexão transcendental na sua tarefa em relação à confusão anfibólica. Mas o sentido positivo da reflexão de modo algum se resume a esta limitação imposta à especulação, e se quisermos apresentá-lo mais claramente devemos aprofundar a relação entre a reflexão e o sentido positivo da especulação.

O uso especulativo da razão é, como acabamos de ver, derivado da natureza própria da razão que exige "a totalidade das condições para um condicionado dado", visando com isso a uma unidade sistemática do conhecimento. Essa unidade é expressa pelas idéias transcendentais da razão, produzidas pela especulação para servir de cânone

\footnotetext{
${ }^{195}$ Cf. KrV, B697 e B705.

${ }^{196}$ Cf. KrV B XXIV, XXV.
} 
ao uso do entendimento na determinação dos objetos da experiência. Nesse sentido, as idéias, assim como os conceitos da reflexão, não possuem um uso constitutivo através do qual forneceria conceitos de determinados objetos, a menos que a razão esteja sob uma ilusão dialética. Os conceitos da razão (idéias) possuem apenas um uso regulativo e imprescindível ao conhecimento, conferindo-lhe maior unidade e extensão: "Por meio deles não se conhece, é certo, mais nenhum objeto, como os que conheceria pelos seus conceitos, mas, não obstante, será melhor conduzido e irá mais longe nesse conhecimento" ${ }^{197}$. Como veremos, essa restrição ao uso meramente regulativo das idéias representará, para Hegel, o signo claro de que aqui se trata de um "idealismo formal" (GuW, p. 314), para o qual a unidade racional das idéias é abstratamente considerada. Uma vez que a idéia foi de antemão destituída de conteúdo e esvaziada em uma unidade meramente formal, não há como reconhecê-la em seu caráter constitutivo, "pois como poderia o simplesmente carente de conteúdo constituir algo?” (GuW, p. 317).

O sentido da noção kantiana de especulação é conseqüentemente intimamente ligado à concepção que Kant faz de idéia da razão, e a sua origem etimológica, retirada do fenômeno de reflexão da luz, torna-se compreensível a partir desta relação. Se as idéias não têm um uso constitutivo, elas

"tem um uso regulativo excelente e necessariamente imprescindível, o de dirigir o entendimento para um certo fim, onde convergem num ponto as linhas diretivas de todas as suas regras e que, embora seja apenas uma idéia (focus imaginarius), isto é, um ponto de onde não partem na realidade os conceitos do entendimento, uma vez que fica completamente fora dos limites da experiência possível, serve todavia para lhes conferir a maior unidade e, simultaneamente, a maior extensão. Disso deriva, é certo, a ilusão de que todas essas linhas de orientação provêm propriamente de um objeto situado fora do campo da experiência possível (assim como se vêem os objetos por detrás da superfície do espelho.” (KrV, B672)

Vemos assim como a idéia tem apenas um uso regulativo para o conhecimento e esse uso se distingue do "uso apodítico da razão", no qual um particular é determinado necessariamente por um universal dado. Trata-se aqui, todavia, daquilo que Kant chama

${ }^{197} \mathrm{KrV}$, B 385. 
de "uso hipotético da razão", uma vez que a idéia permanece um conceito problemático e a "generalidade da regra (...) é ainda um problema" (KrV, B675). A unidade expressa pela idéia é, portanto,

"apenas uma unidade projetada [projektierte Einheit], que não pode se considerar dada em si, mas tão-só como problema; que serve, no entanto, para encontrar um princípio para o diverso e para o uso particular do entendimento e desse modo conduzir esse uso e colocá-lo em conexão com os casos que não são dados" (KrV, B675).

O termo que Kant utiliza para especulação (Spekulation), derivado do latim speculare é também empregado em alemão, ausspähen, como vemos na seguinte passagem da $1^{\text {a }}$ Crítica, em que o caráter regulativo das idéias é apresentado em sua função heurística na perspectiva do "como se" (als ob), constituindo-se numa "máxima necessária" para orientação de como proceder na investigação da natureza:

"Com efeito, a lei regulativa da unidade sistemática quer que estudemos a natureza como se por toda parte, até o infinito, fosse encontrada uma unidade sistemática e conforme a fins [zweckmäßig], na maior multiplicidade possível. Pois, embora especulemos [ausspähen] ou alcancemos um pouco dessa perfeição do mundo, pertence à legislação da nossa razão procurá-la e supô-la por toda parte, e tem que nos ser vantajoso e jamais prejudicial, orientar, de acordo com este princípio, a consideração da natureza" $(\mathrm{KrV}, \mathrm{B} 728) .{ }^{198}$

Podemos a partir disso dizer que a especulação "significa o ver através da reflexão [Zurückbeugung] do raio de luz no centro do espelho (ponto focal, focus), onde a imagem refletida aparece (...). O espelho é a razão e o foco é a idéia da razão, onde procuramos encontrar o Ser supremo, a perfeição do mundo e o fim mais elevado" ${ }^{199}$. Esse focus imaginarius é a fonte da ilusão que infere a existência do objeto que, todavia, não pode ser dado à intuição e cuja admissão somente pode ser relativa (suppositio relativa) uma vez que, embora reconheçamos a necessidade do princípio regulativo, não podemos

\footnotetext{
198 Traduzimos aqui "ausspähen" por especulação que segue o sentido etimológico do termo e julgamos mais de acordo do que a tradução brasileira que opta por "observamos", e a tradução portuguesa que opta por "descobrimos".

${ }^{199}$ Dottori, R, Die Reflexion des Wirklichen, p. 71.
} 
encontrar a origem dessa necessidade ${ }^{200}$. Não tomar a idéia como correspondendo a um objeto existente, mas reconhecer que através dela apenas se admite um "objeto na idéia", isto é, "um esquema ao qual não se atribui diretamente nenhum objeto, nem mesmo hipoteticamente, mas que apenas nos serve para representar os outros objetos mediante a referência a essa idéia, ou seja, indiretamente, segundo a sua unidade sistemática" $(\mathrm{KrV}$, B698) - eis a precaução crítica que faz com que Kant indique a grande "diferença no modo de pensar" em jogo na filosofia transcendental.

A exigência de unidade e sistematicidade da razão especulativa demanda, portanto, um modo de pensar que reconheça a positividade de seus princípios, mas que não ceda sempre novamente às inevitáveis ilusões que dela surgem. A proximidade da especulação e da reflexão, expressa, num primeiro momento apenas no seu sentido etimológico, parece ganhar novas dimensões na medida em que se tem em vista a operação positiva de ambas para o conhecimento. Qual é, pois, a tarefa positiva da reflexão nas operações de sistematização do conhecimento?

A questão da unidade sistemática do conhecimento é uma tarefa recolocada pela Crítica da Faculdade do Juízo, obra na qual a noção de reflexão ganha um novo valor no que diz respeito ao seu papel no conhecimento e, portanto, um novo estatuto em relação ao pensar em geral. Na $3^{\mathrm{a}}$ Crítica, a reflexão não recebe uma determinação inteiramente nova no que se refere à sua forma, e a sua caracterização enquanto comparação das representações entre elas (seguindo o conceito lógico da reflexão, das Logikvorlesungen) assim como a comparação das representações com as faculdades de conhecimento (seguindo o conceito transcendental da reflexão, presente no capítulo da Anfibolia) permanecem inalteradas desde a primeira crítica ${ }^{201}$. Conforme lemos na definição que Kant apresenta no texto da primeira introdução à terceira Crítica: "Refletir [Reflektieren (Überlegen)], porém, é: comparar e manter juntas representações dadas, seja com outras, seja com sua faculdade de conhecimento, em referência a um conceito tornado possível através disso" (EEKU, XX, p. 211).

${ }^{200} \mathrm{Cf} . \mathrm{KrV}, \mathrm{B} 704$.

${ }^{201}$ Cf. Marques, op. cit p. 82. 
O que ocorre, no entanto, é que na $3^{\text {a }}$ Crítica os múltiplos aspectos e funções da reflexão, que já estavam em jogo na $1^{a}$ Crítica, passam a "recobrar sua unidade" ${ }^{202}$, de modo que sua nova tematização implicará necessariamente no "aprofundamento das relações entre reflexão e crítica" ${ }^{203}$. A partir de agora a reflexão aparecerá enquanto operação fundamental da faculdade de julgar, figura central na mediação entre o "abismo" dos dois mundos (sensível e inteligível) e suas distintas legislações, a do entendimento, mediante os conceitos da natureza e a da razão, mediante o conceito de liberdade, ou seja, entre a filosofia teórica e a filosofia prática ${ }^{204}$. A faculdade de julgar irá assim mediar a relação entre essas duas faculdades superiores do conhecimento, sem conter ela mesma uma legislação própria no sentido que aqueles dois domínios possuem, mas contendo um "princípio para procurar leis", e dessa forma, constituindo um solo próprio de investigação ${ }^{205}$.

Desde já vemos que a reflexão, enquanto operação fundamental da faculdade de julgar, receberá uma atribuição de ordem inteiramente nova; pois aquela ação que, de acordo com $1^{\text {a }}$ Crítica, deveria comparar representações com as faculdades do conhecimento a fim de corretamente distingui-las e evitar as confusões derivadas do emprego de um princípio que possui validade apenas em um deles, aparece agora precisamente como atividade que deverá mediar os domínios do sensível e do suprasensível. Essa é a razão pela qual a Crítica da Faculdade do Juizo será determinante para todas as filosofias idealistas subseqüentes que irão procurar conhecer a raiz comum entre esses dois domínios, a qual em Kant permanecia inescrutável ${ }^{206}$. Para Hegel, em

\footnotetext{
202 "Ora, esse ato para o qual é preciso agora encontrar um estado civil já está presente na $1^{\text {a }}$ Crítica, mas espelhado em vários níveis, disperso entre várias funções. É preciso então recobrar sua unidade - reunir as duas acepções já conhecidas da palavra 'reflektieren"'. Lebrun, Kant e o fim da Metafisica p. 376.

${ }^{203}$ Marques, A. A razão Judicativa, p. 82.

${ }^{204}$ Cf. Kant, EEKU, XX, §II.

205 "Só que ainda na família das faculdades de conhecimento superiores existe ainda um termo médio entre o entendimento e a razão. Este é a faculdade de julgar, da qual se tem razões para supor, segundo a analogia, que também poderia precisamente conter em si a priori, se bem que não uma legislação própria, todavia um princípio próprio para procurar leis; em todo caso um princípio simplesmente subjetivo, o qual, mesmo, que não lhe convenha um campo [Feld] de objetos como seu domínio [Gebiet], pode todavia possuir um solo [Boden] próprio e uma certa característica deste, para o que precisamente só este princípio poderia ser válido.” (KU, V, p. 174) ${ }^{206}$ Cf. Horstmann, R-P, Kants 'Kritik der Urteilskraft' im Urtel seiner idealistischen Nachfolger, In: Die Grenzen der Vernunft, pp. 145-169.
} 
particular, a terceira Crítica apresentaria o indício de que a reflexão poderia operar a partir de uma outra perspectiva que não aquela submetida aos contornos críticos.

Essa nova investigação à qual Kant submete a faculdade de julgar implica, portanto, uma reavaliação do sentido do termo reflektieren, que permitirá o realce da sua tarefa positiva em jogo no conhecimento, e a melhor apreciação de seu sentido metodológico ${ }^{207}$, instaurando assim toda uma reconfiguração do que se entendia por pensar. É a transformação do sentido em que se fala de natureza e de experiência que demandará essa nova investigação, uma vez que elas passarão a ter outra amplitude, exigindo da faculdade de julgar uma clarificação do seu modo de refletir que permanecia implícito sob a sua forma determinante ${ }^{208}$, a da subsunção da multiplicidade sensível à categoria do entendimento puro. Agora, na obra de 1790, a experiência da qual se fala não se restringe mais àquela experiência possível, condição de toda objetividade e referente, portanto, ao nível das leis gerais do entendimento. Trata-se agora da experiência de fato - "da rosa [bela] que contemplo", "da gota movendo-se num cristal que percebo", do organismo com que me deparo - e as leis gerais da natureza fornecidas pelo entendimento puro não alcançam a esfera das leis empíricas e particulares da natureza, necessitando de um princípio de unificação que o entendimento não pode lhe ofertar:

${ }^{207}$ Cf. Lebrun, G. Kant e o fim da Metafísica, p. 377.

208 "Talvez a constituição da objetividade seja apenas uma das tarefas que a atividade reflexionante desempenhe, e a menos própria, alías, para revelar sua natureza" Lebrun, G. Op. cit, p. 378 . 
Essa "facticidade" ${ }^{209}$ da natureza exigirá a tematização da faculdade de "pensar o particular enquanto contido no universal" em sua forma meramente reflexionante e não simultaneamente determinante ${ }^{210}$, uma vez que o universal, a regra ou o princípio não é fornecido pelo entendimento para pensar o particular, e a faculdade de julgar reflexionante deve dar a si mesma uma lei (heautonomie) para pensar a unidade das leis empíricas. Agora é a multiplicidade e heterogeneidade das formas da natureza que devem ser pensadas, e assim, toda aquela esfera que permanecia indeterminada pelas regras gerais que a faculdade de julgar determinante recebe do entendimento puro. $\mathrm{O}$ que se oferece como problema, e que motiva toda a $3^{\text {a }}$ Crítica, não é, pois, o universal, mas o particular em sua particularidade, o que exige um ultrapassamento de um modo de pensar que toma o particular a partir de uma representação geral já dada, problema que vai além dos horizontes da Critica da Razão Pura ${ }^{211}$.

É precisamente por isso que a faculdade de julgar se torna agora tema de uma crítica - pois essa faculdade já não mais se encontra restringida à figura do entendimento, e a "inquietante heterogeneidade sem limites das leis empíricas e a heterogeneidade das formas naturais da natureza" (EEKU, XX, p. 209), para a qual ele permanecia cego, deve também poder ser pensada como um sistema. Neste ponto vemos como a Urteilskraft incorpora exigências racionais que o entendimento não é capaz de seguir: o princípio sistemático que é exigido para pensar a natureza em suas múltiplas formas é da mesma ordem daqueles princípios racionais de que o Apêndice à Dialética Transcendental falava, e que não podiam provir do entendimento, uma vez que "o conceito de sistema

${ }^{209}$ Essa exigência de se voltar para aquém da lógica formal e mesmo da lógica transcendental, que não podem conhecer uma natureza de fato, em toda sua diversificação de leis particulares, assemelha o filósofo crítico de um questionamento da fenomenologia de E. Husserl, como bem nos aponta G. Lebrun: "Qual é exatamente, aqui, o ponto comum entre fenomenologia e Crítica do Juízo? Aqui e ali, reconhece-se que o conteúdo da natureza fáctica tem uma racionalidade que lhe é própria, e que deve portanto haver ali um princípio de coerência da experiência, assim como há um de sua possibilidade" Lebrun, Kant e o fim da Metafisica, p. 367.

${ }^{210}$ É importante ressaltar que mesmo na sua maneira determinante de proceder, a faculdade de julgar tem em sua base processos reflexivos, que somente na terceira Crítica recebem a devida atenção. Cf.. Kant, EEKU, XX, §.V.

211 “Ao contrário, a faculdade de julgar reflexionante procura e pensa a lei, sendo de notar que esta procura deve ser motivada pelo particular dado na representação. É, pois, o particular que se oferece como problema para o juízo reflexionante e este fato é decisivo na compreensão de toda a Crítica da Faculdade do Juizo. Um novo domínio problemático se abre nesta, essencialmente diverso da Crítica da Razão Pura, em que o particular não se apresenta como problema só por si”. Marques, A, Organismo e Sistema em Kant, p. 36. 
deve ser completamente estranho ao entendimento", para o qual leis empíricas particulares são sempre consideradas como contingentes ${ }^{212}$. Em outras palavras, ao dedicar uma investigação ao juízo meramente reflexionante (seja ele estético ou teleológico), Kant ampliava os limites do pensar no interior do qual se movia a $1^{\text {a }}$ Crítica, mostrando que a "faculdade de julgar não é forçosamente controlada pela lógica" ${ }^{213} \mathrm{e}$ que há uma camada anterior a ela que deve ser investigada, sem o que todo o edifício de princípios puros permanecia incerto ${ }^{214}$.

Dessa forma, o problema que a $3^{\text {a }}$ Crítica enfrenta é o de apresentar e, em seguida, legitimar o princípio que permite a reflexão comparar e ordenar um objeto particular dado à intuição. Como o que está em jogo não é a natureza em geral e, portanto, a reflexão não tem "no conceito de uma natureza em geral sua instrução [Anweisung]" (EEKU, XX, p. 212), a reflexão necessita de um princípio que assuma o lugar dos conceitos e princípios gerais do entendimento para que ela possa operar, sem o qual ela permaneceria em uma procura cega de leis gerais sob as quais poderia subsumir todas as formas fenomênicas e leis particulares da natureza. Esse princípio não pode ser tirado de nenhum outro lugar "porque então seria faculdade de julgar determinante", mas deve ser dado a si mesma pela própria faculdade de julgar reflexionante (reflektierende Urteilskraft) enquanto uma pressuposição (Voraussetzung) necessária para sua operação (KU, V, §.IV). Este pressuposto deve ser, nas palavras da primeira introdução, o seguinte: "que a natureza, também em relação às suas leis empíricas, observou uma certa parcimônia [Sparsamkeit], adequada à nossa faculdade de julgar e uma uniformidade por nós apreensível” ${ }^{215}$. Ou seja, deve se pressupor, em favor da própria faculdade de julgar,

\footnotetext{
${ }^{212}$ Marques, A. Organismo e Sistema em Kant, p. 148. "Eis, pois, porque o conceito de sistema é estranho ao entendimento: porque em relação a este, as múltiplas leis particulares empíricas são contingentes. De modo que, se estas vierem a receber uma legalidade a priori que supere essa situação de contingência, terá aquela de provir de uma outra fonte que não o entendimento".

${ }^{213}$ Lebrun, G. Kant e o Fim da Metafísica, p. 380.

214 "Pois se um tal sistema sob o nome geral de metafísica alguma vez deve se realizar (...), então a crítica tem que ter investigado antes o solo para este edifício tão profundamente quanto jaz a primeira base da faculdade de princípios independentes da experiência, para que não afunde em parte alguma, o que inevitavelmente acarretaria o desabamento do todo", Kant, KU, V, §. VI.

${ }^{215}$ Essa pressuposição é expressa na segunda introdução da seguinte maneira: "Como as leis universais tem o seu fundamento no nosso entendimento, que as prescreve à natureza (ainda que somente segundo o conceito universal dela como natureza) têm as leis empíricas particulares, a respeito daquilo que nelas é deixado indeterminado por aquelas leis, que ser consideradas segundo uma tal unidade, como se igualmente um entendimento (ainda que não o nosso) as
} 
uma "ordenação conforme a fins da natureza em um sistema", isto é, de uma interconexão legitima de suas leis particulares, que sirva como um horizonte de expectativa para sua atuação, sem o qual nenhuma investigação da natureza saberia como proceder ${ }^{216}$. Esse princípio é o da conformidade a fins (Zweckmäßigkeit) da natureza, que pressupõe uma adequação (Angemessenheit) da especificação da natureza a um sistema lógico concordante com a própria faculdade de julgar: “A natureza especifica suas leis universais em empíricas, em conformidade com a forma de um sistema lógico, em função da faculdade de julgar” (KU, V, p. 186).

Sem esse pressuposto de uma "concordância da natureza com a nossa faculdade de conhecimento", pressuposição esta que é necessária para que uma investigação da natureza, em suas leis empíricas, tenha um "fio condutor" e possa sistematizar a multiplicidade de suas formas, sem esta pressuposição a priori da faculdade de julgar "em favor de sua reflexão" (Zum behuf ihrer Reflexion) sobre a natureza não haveria a possibilidade de qualquer ordenação e organização da natureza no nível de suas leis empíricas particulares. A expressão "em favor de sua reflexão" visa mostrar que, embora necessário, esse princípio da conformidade a fins não pode ser prescrito à natureza, como o são as categorias e princípios do entendimento puro ${ }^{217}$, mas apenas à própria faculdade de julgar, isto é, “do ponto de vista de uma consideração subjetiva de si própria” (KU, V, p. 185) e a favor de uma ordem das leis particulares e da progressão do conhecimento. $\mathrm{O}$ princípio da faculdade de julgar deve ser um pressuposto para a sua reflexão para a "adequação" da especificação das leis da natureza ao "nosso entendimento humano em sua necessária atividade", sem o qual nossa faculdade de conhecer não poderia integrar os conhecimentos que obtém empiricamente na sua investigação da natureza.

"A unidade da experiência (como de um sistema segundo leis empíricas) (...) tem que ser necessariamente pressuposta e admitida, pois de outro modo não existiria

tivesse dado em favor da nossa faculdade de conhecimento, para tornar possível um sistema da experiência segundo leis particulares da natureza", Kant, KU, V, p. 179.

${ }^{216}$ Cf. Kant, EEKU, XX, p. 212 "Pois se não pudessemos pressupor isto, e não puséssemos esse princípio no fundamento de nosso tratamento das representações empíricas, todo refletir seria instaurado meramente ao acaso e às cegas, portanto sem expectativa fundada de sua concordância com a natureza".

${ }^{217}$ Cf. KrV, B 692. 
qualquer articulação completa de conhecimentos empíricos para um todo da experiência...” (KU, V, p. 183).

Portanto, essa unidade da natureza nas suas leis particulares deve ser admitida a priori como um princípio pela faculdade de julgar reflexiva, e aquilo que é "contingente para compreensão humana” deve ser "para nós uma unidade legitima." (KU, V, pp. 183-4). Para nós, isto quer dizer, em concordância com uma necessidade (Bedürfnis) de nossa faculdade de conhecer e que tem sua origem meramente na faculdade de julgar reflexionante.

Esse conceito a priori da conformidade a fins da natureza é, conseqüentemente, um “princípio subjetivo (máxima) da faculdade de julgar”, pois é “a única forma segundo a qual nós temos que proceder na reflexão sobre os objetos da natureza com o objetivo de uma experiência exaustivamente interconectada" (KU, V, p. 184), e não um princípio de uma determinação própria aos objetos da natureza. Todavia, embora esse princípio seja reconhecido como meramente subjetivo, o texto da $2^{\text {a }}$ Introdução o apresenta como um princípio transcendental da faculdade de julgar, isto é, como um princípio que torna possível o conhecimento. "Um princípio transcendental é aquele pelo qual é representada a priori a condição universal, apenas sob a qual as coisas podem ser objetos do nosso conhecimento" (KU, V, XXIX). É o caso do princípio de Zweckmäßigkeit, que é posto a priori "como fundamento da investigação da natureza" e do qual depende, portanto, o seu conhecimento. A partir disso podemos já medir o passo decisivo que a $3^{\text {a }}$ Crítica toma em relação ao papel da reflexão no conhecimento. Se no capítulo da Anfibolia o ato de reflexão era o de denunciar e evitar a confusão do uso lógico com o uso transcendental e, assim, explicitar a distinção necessária à precaução crítica entre o uso empírico e o uso transcendental do entendimento, agora aquilo que na primeira introdução à Crítica $d a$ Faculdade do Juízo ainda é considerado como um princípio lógico da reflexão passa a ter um valor transcendental e um uso empírico imanente. Lemos no texto da primeira Introdução o seguinte:

"O princípio da faculdade de julgar reflexionante, pelo qual a natureza é pensada como sistema segundo leis empíricas, é, porém, meramente um princípio para o uso lógico da faculdade de julgar, decerto um princípio transcendental segundo sua origem, mas somente para 
considerar a priori a natureza como qualificada em um sistema lógico de sua diversidade segundo leis empíricas" (KU, V, p. 214).

Esse uso de um princípio lógico aplicado a objetos da experiência não será, todavia, seguido da acusação de confusão anfibólica, pois o valor transcendental desse princípio foi reconhecido e legitimado, mesmo que o juízo dele proveniente permaneça meramente reflexionante e não assuma jamais um caráter determinante. Note-se ainda que se à reflexão da $1^{\mathrm{a}}$ Crítica era atribuída a tarefa de distinguir claramente as instâncias de legitimação de um juízo objetivo e, nesse sentido, ratificar e manifestar a distinção transcendental das faculdades, isto é, a sensibilidade e o entendimento ${ }^{218}$, agora lhe é reconhecida a operação de mediação entre esses dois domínios, na medida em que se atribui um valor constitutivo (embora não determinante) a uma operação de natureza lógica. Se em relação aos conceitos da reflexão havia sido reconhecida uma ambigüidade que possibilitava a confusão de seu uso pelo entendimento, e a anfibolia consistia precisamente no emprego, aos objetos dos sentidos, de princípios que exprimiam apenas uma ligação lógica de representações; se, pois, a reflexão transcendental, enquanto retorno da consciência à relação das representações com as faculdades de conhecimento, surgia como exigência para prevenção dessas confusões; e, por fim, se os conceitos de reflexão eram, neste sentido, privados de qualquer caráter constitutivo, e sua função resumia-se à comparação das representações em nome da reflexão transcendental enquanto momento de uma tópica transcendental, - vemos agora a reflexão possuindo um valor transcendental, isto é, constitutivo para o conhecimento dos objetos da experiência, e o princípio da faculdade de julgar reflexionante é assegurado, na $2^{\mathrm{a}}$ Introdução à Kritik der Urteilskraft, em seu estatuto de princípio transcendental ${ }^{219}$.

Ultrapassaria assim a reflexão a finitude que lhe fora inscrita na Crítica da Razão Pura, e em nome da qual ela opera no desmascaramento de toda pretensão que a extrapole? Não parece ser o caso, para decepção de Hegel que aponta a circunscrição desse princípio que enuncia a unidade racional da natureza à subjetividade finita,

\footnotetext{
218 “Sem essa 'Reflexão transcendental' - ato especificamente crítico, já que é apenas nele que se manifesta a necessidade da distinção entre entendimento e sensibilidade - desliza-se inevitavelmente para o dogmatismo, já que de fala estabanadamente de conceitos, sem interrogarse sobre sua origem". Lebrun, Kant e o fim da Metafísica, p. 376.

${ }^{219} \mathrm{Cf} . \mathrm{KU}, \mathrm{V}, \S . \mathrm{V}$.
} 
alertando que a cláusula do "für uns Menschen" continua ativa desde a $1^{\text {a }}$ Crítica, e que essa subjetividade finita deve permanecer um absoluto para o conhecimento ${ }^{220}$. Se o princípio de conformidade a fins é um princípio transcendental a priori da faculdade de julgar, ele o é, todavia, na medida em que é um pressuposto subjetivamente necessário, isto é a partir de uma necessidade (Bedürfnis) da nossa faculdade do conhecimento (humana) para a operação da reflexão em face da heterogeneidade das formas da natureza. Trata-se de uma "pressuposição transcendental subjetivamente necessária" 221 que serve "meramente ao sujeito" como um "princípio heurístico" de investigação da natureza e nada acrescenta ao "sistema doutrinal do conhecimento da natureza": "O conhecimento da natureza não é enriquecido com nenhuma lei objetiva particular, mas é apenas fundada uma máxima para a faculdade de julgar para observá-la de acordo com ela e, com isso, manter juntas as formas da natureza" (EEKU, XX, p. 205).

É verdade que na segunda parte da Crítica da Faculdade do Juízo, em que se aborda o juízo teleológico, Kant fala em uma conformidade a fins objetiva, isto é, que não é meramente formal e subjetiva como aquela do juízo estético em que encontramos apenas uma adequação da forma do objeto às faculdades do conhecimento. No juízo teleológico estamos diante de objetos particulares que não são explicáveis a partir de uma causalidade mecânica, e cuja própria possibilidade interna pressupõe um fim, isto é, "um conceito, que está, como condição, no fundamento da causalidade de seu engendramento" (EEKU, XX, p. 232). As coisas como "fins naturais" (Naturzwecke) são aquelas que têm uma finalidade interna, isto é, que possuem em si mesmas sua necessidade: "uma coisa existe como fim natural quando é causa e efeito de si mesma" (KU, V, p. 370).

"A experiência conduz a nossa faculdade de julgar ao conceito de uma finalidade objetiva e material, isto é, ao conceito de um fim da natureza, somente quando se trata de

\footnotetext{
220 "Kant reconhece muito bem que essa não é uma afirmação objetiva, e sim apenas algo subjetivo, mas essa subjetividade e finitude da máxima deve permanecer o conhecimento absoluto. Em si não é impossível que o mecanismo coincida com a conformidade a fins da natureza, mas é impossível para nós homens, na medida em que seria necessário para o conhecimento desta coincidência uma outra intuição que a sensível e um conhecimento do substrato inteligível da natureza, a partir do qual seria possível indicar o fundamento mesmo para o mecanismo dos fenômenos segundo leis particulares - o que ultrapassaria completamente toda a nossa capacidade." Hegel, GuW, pp. 327-28.

${ }^{221}$ EEKU, XX, p. 209. O grifo é de nossa autoria.
} 
apreciar uma relação de causa e efeito, a qual somente compreendemos como legal quando colocamos a idéia do efeito no fundamento da causalidade da causa, como a condição de possibilidade desse efeito" (KU, V, p. 366).

Encontramos aqui, pela primeira vez, um "conceito de conformidade a fins não meramente para o modo de representar, mas para a possibilidade da coisa mesma" (EEKU, XX, p. 234). Diferentemente do juízo estético, a reflexão assume agora um papel decisivo para o conhecimento da possibilidade de um objeto, e na medida em que o orgânico exige da reflexão a identidade da possibilidade e efetividade desse produto da natureza, Hegel poderá reconhecer aqui a verdadeira unidade expressa pela idéia da razão ${ }^{222}$. Na concepção de orgânico o juízo teleológico tem um valor de conhecimento na medida em que explica a existência desses objetos como fins da natureza. Encontramos aqui, pois, um ponto que será essencial ao aprofundamento da reflexão que Hegel realizará: Kant está afirmando de maneira decisiva que a reflexão da faculdade de julgar tem de pressupor em sua operação uma unidade da natureza, uma unidade da vida como condição de ordenação do conhecimento: "a essa unidade da vida é que toda pressuposição da reflexão deve ser remetida" ${ }^{223}$.

No entanto, esse pressuposto expresso pelo princípio transcendental de conformidade a fins não pode, na filosofia crítica, ir além de uma relativização à subjetividade. Pois todo o valor referente ao conhecimento que é conferido a este princípio é sempre reconduzido a uma perspectiva subjetiva, uma vez que, mesmo no juízo teleológico, em que um conceito de fim tem de ser admitido na natureza, esse princípio de conformidade a fins objetiva e material continua sendo um pressuposto para a faculdade de julgar reflexiva e não perde jamais o estatuto de uma máxima subjetiva, permanecendo um princípio para o juízo que não fornece um conhecimento objetivo da natureza:

"nesses casos, o conceito de uma conformidade a fins
objetiva da natureza serve apenas a favor da reflexão sobre
o objeto [zum Behuf der Reflexion über das Objekt], e não
para a determinação do objeto através do conceito de um
fim, e o juízo teleológico sobre a possibilidade interna de

${ }^{222}$ Hegel, GuW, p. 59. Cf. Também, VGPh, HW XX, p. 377.

${ }^{223}$ Dottori, R, Die Reflexion des Wirklichen, p. 92. 
um produto da natureza é um juízo meramente reflexionante e não determinante" (EEKU, XX, p. 236) ${ }^{224}$.

Nós homens não conhecemos a "natureza em si", e a distinção crítica entre os fenômenos e as coisas em si não pode deixar de fazer com que a objetividade a que se chega não esteja já, de antemão, necessariamente oposta e submetida a uma subjetividade finita.

"Por meio deste modo humano de considerar, escreverá Hegel em Jena, nada deve ser expresso acerca da realidade da natureza; o modo de considerar permanece, portanto, inteiramente subjetivo e a natureza como algo de puramente objetivo, um pensado" (Hegel, DS, p. 103).

Isto porque "a faculdade de julgar teleológica é apenas uma faculdade subjetiva, seus conhecimentos tem apenas um valor de verdade subjetivo" 225 e toda forma de "verdadeira objetividade" permanece como uma transcendência não legitima para o conhecimento de um sujeito finito. Não é por acaso que as operações de reflexão recebam um tratamento importante na Antropologia, na qual vemos seus procedimentos sendo diretamente vinculados à operações psicológicas ${ }^{226}$. E aquela "exigência do concreto" 227 que Hegel vê motivar a Crítica da faculdade do Juízo, acaba por retornar à abstração das faculdades subjetivas do conhecimento humano.

Se por um lado, portanto, a reflexão apresentada na $3^{\text {a }}$ Crítica parece exigir um ultrapassamento dos limites impostos a ela pela obra de 1781, pois parece afrouxar a distinção que a pôs em jogo, por outro os pressupostos críticos, ainda em pleno vapor, não o permitem. Esta é a tensão que se apresenta na reflexão kantiana: na mesma medida em que reconhece como necessário um pressuposto para si própria, não pode, contudo, desenvolvê-lo; e o lugar em direção ao qual levanta os olhos permanece muito distante para alcançar com a vista. "Com efeito, Kant faz um percurso que parece

\footnotetext{
${ }^{224}$ EEKU, XX, p. 236. Comparar com as censuras de Hegel, nas VGPh, XX, p.379.

${ }^{225}$ Kroner, Von Kant bis Hegel, I, p. 290-91. "Como ela [reflexão subjetiva] não tem a natureza como seu objeto, mas seu substrato supra-sensível, e este se recusa a todo conhecimento, então o principio de conformidade a fins objetiva não é outra coisa senão uma máxima que a faculdade de julgar prescreve a si, a qual não vale para a natureza, nem enquanto fenômeno, nem enquanto essência, nem enquanto mundo dos sentidos, nem enquanto mundo inteligível - que, portanto, não pode fornecer nem uma condição da experiência possível, nem um fundamento explicativo metafísico que transcenda a experiência." (p. 284.)

${ }^{226}$ Cf. Kant, Anth, VII, pp. 133-142.

${ }^{227}$ Hegel, VGPh, HW XX, p. 372.
} 
conduzi-lo para além de si mesmo, mas retorna imediatamente aos limites por ele mesmo estabelecido. Ele os toca, mas não os ultrapassa, apenas novamente se recoloca dentro deles de maneira ainda mais fixa e estreita" ${ }^{228}$.

Se na terceira crítica o entendimento e a aplicação de regras se revelam como não sendo um absoluto para a razão; e se há ali uma unidade racional pressuposta pela atividade de reflexão que faz com que ela vá além do mero emprego lógico de conceitos, assim como do conceito geral de natureza - isto será, sem dúvida, motivo de grandes elogios por parte Hegel. Contudo, na medida em que este princípio de uma unidade racional permanece um mero pressuposto para a reflexão, uma "maneira de considerar" (Betrachtungsweise) subjetiva, o conhecimento verdadeiramente objetivo, que através dele deveria se realizar, não deixa de ser para ela uma ficção. Se, portanto, o aspecto formal do sistema kantiano parece aqui inicialmente perder força, é para num segundo momento ele aparecer de maneira ainda mais decisiva e ser reabsorvido no "princípio da subjetividade" do qual não pode abrir mão, elevando o conhecimento finito a um absoluto. Aquilo que o juizo reflexionante parece exigir, a saber, uma "reflexão da reflexão", um aprofundamento da reflexão, não pode ter significado no interior do discurso crítico. Ocorre que se a reflexão finita permanece o limite para o pensamento, então ela deve permanecer cega para aquilo que pretende ver, e sua operação sobre os objetos será sempre uma mera função exercida pelo sujeito que jamais sai verdadeiramente de si. Esta "depreciação da reflexão" ${ }^{229}$ na filosofia crítica, que the priva de qualquer caráter ontológico, é o que faz com que a própria reflexão finita permaneça o seu horizonte, e todo conhecimento que se dê no interior desta sua moldura terá de ser sempre um saber finito ${ }^{230}$.

Para Hegel, reconhecer a possibilidade de uma participação positiva da reflexão no conhecimento e contudo não poder efetivamente (objetivamente) realizá-la é sinônimo de uma exigência de ultrapassamento dessa figura que ali não pode superar os pressupostos da Crítica. É precisamente a partir do caminho aberto pela tensão da

\footnotetext{
${ }^{228}$ Kroner, R. Von Kant bis Hegel, I, p. 239.

${ }^{229}$ Kroner, R. Von Kant bis Hegel, I, p. 291.

230 "É portanto a limitação crítica da subjetividade teórica que impede a determinação da natureza em termos de organização e finalidade". Silva, F. L. Subjetividade e Juízo, p. 34. In: Discurso (19), 1992.
} 
reflexão kantiana que se encontra a particularidade de Hegel no interior do movimento de "ir além de Kant" comum aos sistemas filosóficos do idealismo alemão. Isto é, a exigência de um aprofundamento da reflexão, uma reinterpretação da reflexão à luz da tarefa especulativa de conhecer o absoluto. Como afirma J. Hyppolite, "é por não haver aprofundado suficientemente essa reflexão para ultrapassá-la a conservando [la dépasser em la conservant] (...) que Kant permanece nela. Mas há também no sistema transcendental kantiano o germe de seu ultrapassamento" 231.

Acompanhamos, portanto, nesse capítulo os sentidos que a figura da reflexão assume na filosofia de Kant tendo como horizonte o seu caráter metodológico, sua centralidade no empreendimento crítico e, simultaneamente, a tensão que essa operação está constantemente exprimindo. Terminamos essa sua segunda parte indicando que muito embora a reflexão transcendental caracterize de maneira fundamental o pensar crítico, o procedimento reflexivo, ele mesmo, não se identifica totalmente à operação crítica. Nesse sentido, a partir desta diferença perceptível no próprio texto kantiano, podemos reconhecer como a reflexão se apresenta nela como um modo de pensar assumido pela crítica, mas que não tem necessariamente de compartilhar de suas decisões prévias. Isso é fundamental para que se possa reconhecer naquilo que estamos chamando de reinterpretação especulativa da reflexão a liberação da reflexividade das amarras a que foi submetida pela filosofia crítica. Será com a possibilidade de uma interpretação não-crítica da reflexão que a experiência intelectual de Hegel irá se confrontar no período de transição de Frankfurt a Jena, tema de nosso próximo capítulo.

${ }^{231}$ Hyppolite, J. La Critique Hegelianne de la Reflexion Kantienne, In: Kant-Studien, Band 45, Heft 1-4 (1953/54), p. 85. 


\section{CAPÍTULO III}

\section{REFLEXÃO E VIDA}

"No que diz respeito à necessidade universal da filosofia [allgemeine Bedürfnis der Philosophie], queremos buscar esclarecer na forma de uma resposta a pergunta: qual relação mantém a filosofia com a vida?, uma pergunta que é idêntica àquela: em que medida a filosofia é prática? Pois a verdadeira necessidade da filosofia não se refere a nada senão a através dela e a partir dela aprender a viver" (Hegel, Introduction in Philosophiam, p.259) ${ }^{232}$.

No capitulo anterior dedicamo-nos a seguir os passos do conceito de reflexão na obra de Kant tendo como horizonte de nossa tematização a tensão que nele se expressa, e a partir da qual Hegel reconhece a necessidade de um ultrapassamento e aprofundamento da reflexão crítica kantiana em direção à reflexão especulativa. Vimos como a reflexão kantiana estava fundamentalmente ligada à tarefa de prevenção de prejuízos e de precaução em relação aos enganos da razão, atitude em acordo com uma época de Aufklärung. Nisso consistia fundamentalmente a tarefa negativa da reflexão. Por outro lado, pudemos ver como à reflexão era atribuída simultaneamente uma tarefa positiva no conhecimento, sendo ela uma operação necessária à regulação e à orientação de todo procedimento cognitivo na investigação da natureza. Esta positividade, todavia, permanecia, na filosofia de Kant, presa aos pressupostos críticos, não podia se reconhecer efetivamente nos fenômenos da natureza, mas devia ser sempre remetida à perspectiva do sujeito em sua consideração acerca da experiência. Esse era um dos resultados inevitáveis para uma filosofia que segue coerentemente aquilo que Hegel chamara de "princípio da subjetividade" ao caracterizar as filosofias da reflexão.

\footnotetext{
${ }^{232}$ Hegel, Fragmente aus Vorlesungsmanuskripten (1801/1802), In: G. W. F. Hegel. Gesammelte Werke, Band V, pp. 255-275
} 
Kant aproximava-se do reconhecimento do valor constitutivo da reflexão em sua $3^{\text {a }}$ Crítica, na qual a reflexão surgia com um novo estatuto, como uma operação que exige um pressuposto para sua própria atividade. Este pressuposto era o princípio de conformidade a fins, que nada mais enunciava do que a própria exigência da razão em encontrar correspondida na natureza, em suas múltiplas formas, a mesma unidade que encontra em si mesma. Tal princípio, pressuposto da reflexão, era, como vimos, o pressuposto de uma unidade na natureza, de unificação de sua diversidade de formas, enfim, o pressuposto de uma unidade da vida. Se Kant pôde reconhecer este princípio como um pressuposto necessário da reflexão, não pôde, contudo, segundo a censura de Hegel, desenvolvê-lo, isto é, encontrá-lo efetivamente na vida e nos seus objetos, tendo de reconduzindo-lo à qualidade de uma máxima subjetiva de orientação na nossa consideração da natureza. Na medida, portanto, em que a reflexão era compreendida como uma ação do sujeito e em vista do sujeito, a vida e as suas formas heterogêneas permaneciam sempre um além para a reflexão que pretende pensá-la, de modo que vida e reflexão conservavam-se contrapostas uma a outra. Em outras palavras, para uma filosofia que tem como princípio a subjetividade finita, reflexão e vida permanecem em infinita contraposição. Tal era, pois, o diagnóstico feito por Hegel.

No presente capítulo pretendemos realizar uma aproximação da experiência da transformação do pensamento de Hegel na passagem de Frankfurt a Jena, tendo precisamente como foco a relação conflitante entre reflexão e vida que se configura como um dos horizontes centrais dos textos deste período. Em um sentido amplo pretendemos com isso perguntar em que medida Hegel pôde desenvolver aquele pressuposto da reflexão kantiana, a unidade da vida, de modo a suprimir a heterogeneidade última, absolutamente fixada na filosofia de Kant, entre reflexão e vida. De modo mais específico, contudo, temos como meta compreender em que medida essa relação entre reflexão e vida, pensadas inicialmente no interior de uma temática voltada propriamente à religião e suas formas históricas específicas, aproxima Hegel cada vez mais da filosofia, isto é, de uma forma de pensar a princípio recusadas precisamente pela distância que toda forma de conhecimento mantém em relação ao objeto a que se dirige.

Na já mencionada carta a Schelling de Novembro de 1800, Hegel escrevia ter sido impelido para a ciência e afirmava que "o ideal de juventude teve de se transformar na 
forma da reflexão" ${ }^{233}$. Esta transformação de seu pensamento, anunciada ao futuro companheiro de edição do Kritisches Jornal der Philosophie, de modo algum tem em vista deixar para trás suas preocupações "com necessidades subordinadas dos homens", horizonte principal a partir do qual Hegel elabora suas análises sobre a religião e a moralidade em seus primeiros escritos ${ }^{234}$. Ao contrário, a "intervenção na vida dos homens" ${ }^{235}$, a determinação de sua situação histórica e de suas necessidades presentes se torna um dos focos norteadores do pensamento de Hegel em Jena. Isto quer dizer, portanto, que se quisermos compreender o significado da transformação de seu pensamento devemos considerá-la como respondendo a uma exigência que surge do interior mesmo das "necessidades dos homens" (Bedürfnisse der Menschen), de forma que a reabilitação do pensar reflexivo e da filosofia apenas recebe seu sentido na sua correspondência com a dinâmica própria da vida. Esse é o sentido da afirmação de Hegel que escolhemos como epigrafe para este capítulo e que aparece nos primeiros cursos de Jena (1801-02). Ali ele afirma que voltar-se à "necessidade da filosofia" significa fundamentalmente perguntar: "qual a relação que a filosofia mantém com a vida?" 236.

Como veremos, até o final do período de Frankfurt a religião se configura para Hegel como sendo a única forma de apreensão do modo de ser da vida, e a constatação da insuficiência da forma de pensar característica do entendimento (Verstand), assim como das limitações de uma compreensão ordinária de sua linguagem constituirão pontos centrais de seus escritos ${ }^{237}$. Apenas a partir de Jena, a filosofia (forma da reflexão) assumirá definitivamente o primeiro plano nessa tarefa, e colocará para si mesma a tarefa de construir reflexivamente um conhecimento positivo da vida. Essa nova perspectiva, nascida deste impulso à "forma da reflexão", articula-se como uma re-significação da

${ }^{233}$ Briefe von und an Hegel, (02.11.1800), Band. I, p. 59.

${ }^{234}$ A importância da religião e da moralidade na "nossa vida", na vida dos homens é o tema do início dos fragmentos sobre a religião do povo (1793-1794). Cf. Fragmente über Volksreligion und Christentum, HW I, p. 9.

${ }^{235}$ Trata-se da continuação imediata da carta a Schelling: "Pergunto-me agora, enquanto ainda me ocupo com isso, que retorno se tem de encontrar para intervir na vida dos homens". Briefe von und an Hegel, (02.11.1800), Band I, p. 59-60.

${ }^{236}$ Hegel, Introductio in Philosophiam. In: Fragmente aus Vorlesungsmanuskripten (1801/1802), In: G. W. F. Hegel. Gesammelte Werke, Band 5, p. 261.

237 "Querer exprimir a unidade na linguagem da reflexão (ou da filosofia), isto é, querer edificar o sistema (unidade pensada), é querer apresentar a unidade no elemento da não unidade, é contradizer o conteúdo por sua forma". Bourgeois, B. Hegel a Francfort, ou Judaïsme Christianisme-Hegelianisme, p. 25. 
atividade reflexiva, e que, conforme veremos, não implicará o abandono das formas e categorias tradicionais do pensamento reflexivo, mas antes a sua reinterpretação a partir de uma nova perspectiva. Esta exigência de um desenvolvimento de uma nova forma de reflexão é o germe daquilo que Hegel chama de especulação. "Em Frankfurt é que vemos Hegel forjar esses conceitos que, do interior da reflexão, fazem violência à reflexão (...) conceitos que reenviam a isso que para a reflexão (diferenciadora) é o outro da reflexão..." ${ }^{238}$. Ou seja, o esforço em pensar a vida através daquilo que em Frankfurt Hegel chama de "linguagem da reflexão" o levará a desenvolver uma nova linguagem, que não será uma recusa das categorias da reflexão, mas ao contrário o seu aprofundamento. Esta hesitação de sua linguagem, e o gradual ultrapassamento "linguagem da reflexão" em direção ao que poderíamos chamar de uma "linguagem da especulação', é o que pretendemos apresentar nesse capítulo.

Nosso objetivo nesse capítulo não é, portanto, o de reconstituir os numerosos aspectos que são abordados por Hegel e que sem dúvida contribuem para o desenvolvimento que a obra de Hegel sofre na passagem do período de Frankfurt para o de Jena ${ }^{239}$, mas sobretudo compreender essa transformação do pensamente de Hegel à luz da mudança do estatuto da reflexão.

\section{A unidade concreta da vida e a unidade abstrata do conceito}

A noção de vida (Leben) acompanha Hegel desde seus primeiros escritos, ainda não sendo, todavia, propriamente tematizada em Tübingen e Berna enquanto um princípio próprio de unificação, como apenas o será em Frankfurt. Primeiramente, no entanto, ela aparece através da idéia de uma "vivacidade" (Lebendigkeit) exigida por todas as formas de unidade verdadeira esboçadas por Hegel como forma de superação da

\footnotetext{
${ }^{238}$ Bourgeois, B. Hegel a Francfort, ou Judaïsme - Christianisme - Hegelianisme, p. 26.

${ }^{239}$ Não carecemos de bibliografia a esse respeito. Cito aqui algumas obras que abordam em pormenores essa transição: Rosenkranz K. G. W. Hegels Leben (1844); Haym, R. Hegel und seine Zeit (1857); Dilthey, W, Die Jugendgeschichte Hegels (1905); Haering, T. Hegel. Sein Wollen und Werk. (1929); Luckács, G. Der junge Hegel (1948); Henrich, D Hegel im Kontext (1967); Bourgeois, B Hegel à Francfort ou judaïsme-christianisme-hegelianisme (1970); Fujita, M, Philosophie und Religion beim jungen Hegel (1985); Baum, M Die Entstehund der hegelschen Dialektik (1986).
} 
positividade das religiões objetivas e das cisões que delas derivam. Enquanto objetiva, uma religião pode ser ordenada perfeitamente em um sistema organizado pelo entendimento, ser "apresentada em um livro", mas permanece nessa forma um "capital morto" para os homens se não tiver a efetividade nas "sensações e ações" humanas: "Se digo que um homem tem religião, isto não significa que ele possui grandes conhecimentos da mesma, mas sim que seu coração sente as ações, a maravilha, a proximidade da divindade...” (HW I, pp. 13-14). Em oposição à religião objetiva, Hegel apresenta o que seria uma religião subjetiva, afirmando ser esta "viva [lebendig], efetividade no interior do ser e atividade em direção ao exterior". Se a religião objetiva diz respeito a um conhecimento geral e nesse sentido abstrato acerca de Deus - como uma "mera ciência de Deus", "teologia" (HW I, pp. 11,16) -, a religião subjetiva é aquela experimentada e sentida por cada indivíduo, e na medida em que diz respeito ao coração e às sensações, ela pode ter uma verdadeira efetividade na vida dos homens, não se reduzindo ao caráter abstrato do conhecimento. Vida e a vivacidade são apresentadas aqui como a própria dinâmica que constitui o caráter distintivo de uma religião subjetiva em oposição às formas rígidas de positivação da experiência religiosa, como a passagem seguinte descreve de maneira bastante ilustrativa:

"Religião subjetiva é algo individual, a objetiva a abstração; aquela é o livro vivo da natureza, as plantas, insetos, aves e animais como vivem entre si uns com os outros, cada um vive, cada um desfruta [genießt], eles estão misturados; em toda a parte encontram-se toda as formas convivendo juntas. A religião objetiva, por sua vez, é o gabinete do professor da natureza, que matou os insetos, desidratou as plantas, empalhou os animais ou os conserva em álcool e que organiza tudo junto o que a natureza cindiu, ordenando de acordo com um fim, onde a natureza absorveu uma multiplicidade infinita de fins em uma ligação amigável [freundschafliches Band]" (HW I, p. 14).

Em oposição à reflexão arbitrária do cientista, a vida apresenta uma coesão e um dinamismo que o modo abstrato de proceder próprio à reflexão não é capaz de apreender, estabelecendo cisões nessa unidade que Hegel chama de "ligação amigável", cisões e separações que não correspondem àquelas separações e formações internamente produzidas pelo próprio modo de ser da vida. A religião objetiva criticada por Hegel é, 
nesse sentido, aquela que mantém seus diversos elementos separados e sem efetividade, isto é, mortos e sem se mostrar capaz de unificá-los em uma "unidade viva" (lebendige Einheit). Uma religião que se pretenda fundada apenas em um "esclarecimento do entendimento" (Aufklärung des Verstandes) não age sobre os homens e suas ações senão coercitivamente, não contribuindo para a moralidade dos homens: "esclarecimento do entendimento torna [o homem], com efeito, mais esperto, mas não melhor”. Ao contrário, uma religião positiva elimina a liberdade do homem na medida em que suas regras e mandamentos exercem uma dominação (Herrschaft) sobre os aspectos naturais e sensíveis do homem.

Todo o esforço de Hegel nesses primeiros textos caminha na direção de pensar uma religião ideal como forma de recuperação da unidade harmônica entre os homens em sua existência concreta, tanto no plano religioso quanto no plano político, nos quais vigora, no mundo moderno, a separação absoluta e a desarmonia. A época moderna é caracterizada pela sobreposição de uma "religião privada" - preocupada com a educação moral do indivíduo singular - em relação ao "espírito do povo" (HW I, p. 42), unidade viva somente na qual os homens se encontram em situação de liberdade. Em oposição à vida harmônica dos gregos e a partir do sentimento de uma "dolorosa nostalgia" em relação a esta harmonia dos antigos, Hegel busca indicar como a situação de seu tempo é caracterizada por uma cisão no interior da vida política e na vida religiosa, cindindo governantes e governados, homens e Deus, buscando assim denunciar assim os obstáculos que impedem a recuperação daquela vida enquanto totalidade harmônica ${ }^{240}$.

Impulsionado em parte pela idéia provinda da filosofia de Kant de uma "religião racional", que redimensiona a religião como surgindo de uma "necessidade [Bedürfnis] da razão prática", e entusiasmado pela idéia de "formar o espírito do povo", desenvolvendo no homem o "sentido para as questões morais" (Sinn fürs Moralische) ${ }^{241}$

${ }^{240}$ Cf. Haering, T. Hegel. Sein Werk und sein Wollen, I, p. 63 e também: Bourgeois, B. Hegel a Francfort, ou Judaïsme - Christianisme - Hegelianisme, p. 10.

${ }^{241}$ HW I, p. 15. Embora possamos falar em um verdadeiro "kantismo de Hegel" (cf. Bondeli, 1997) somente no período de Berna, não há dúvida de que Hegel já se oriente em Tübingen a partir do enquadramento oferecido pela filosofia prática kantiana, em especial a questão dos móbeis morais da vontade, (Cf. Beckenkamp, op. cit., p. 43-44), assim como pela idéia de uma "religião racional" apresentada na obra de Kant $A$ religião nos limites da simples razão, de 1793. Todavia, o recurso aos temas do coração, da fantasia, da sensibilidade em geral e da própria 
através de uma "religião do povo" (Volksreligion), Hegel pretende combater nas esferas da vida ética, política e religiosa, o caráter de dominação (Beherrschen) assumido por toda espécie de moralidade que se encontra fundada em um universal (lei, mandamento, conceito) que impera sobre os homens como uma "potência estranha" (fremde Macht). Em oposição à religião sem vida dos modernos, Hegel deseja recuperar a experiência de uma religião viva (lebendige Religion) simbolizada pelas figuras do coração e da fantasia ${ }^{242}$, caracterizando assim a religião ideal como sendo aquela que se recusa em se cristalizar em formas positivas que submetem o homem a uma idéia de moralidade que pretende eliminar o seu aspecto natural e sensível (multiplicidade), tornando-o, por conseqüência, escravo de leis, regras e normas que lhe são estranhas, e nada dizem ao coração. A religião é viva, ao contrário, quando não recusa os aspectos sensíveis do homem natural, mas os reconhece como fundamentais para que a lei moral possa ter "receptividade" (Empfänglichkeit), abandonando assim o caráter de dominação.

Lebendigkeit é, desta forma, neste período inicial, o signo mesmo da liberdade ("unidade viva") nas diversas relações entre os homens na vida política e religiosa, e desde os primeiros escritos já se opõe a uma relação estática forjada por um entendimento frio e separador, uma oposição que será cada vez mais intensificada nos escritos do período de Frankfurt. A figura que assume o papel central dessa censura de Hegel é o entendimento (Verstand) que, em sua atividade reflexiva, é incapaz de acender a chama da moralidade e estimular a religião subjetiva. "A religião obtém através do entendimento muito pouco, suas operações suas dúvidas podem, ao contrário, mais esfriar do que aquecer o coração" ${ }^{243}$.

Apesar da crítica a uma religião do entendimento e à exclusão dos aspectos sensíveis na formação do sentido moral, Hegel compartilha, até o período de Frankfurt, do horizonte geral aberto pela filosofia moral kantiana, que concentra suas análises sobre o problema dos móbeis morais da vontade ${ }^{244}$. Será apenas a partir de Frankfurt que a própria perspectiva apresentada pela moralidade kantiana aparecerá, aos olhos de Hegel,

religião como fomentando a moralidade já indicam uma distância do encaminhamento dado por Kant à questão da moralidade em sua filosofia prática.

242 "Toda religião que deve ser uma religião popular, deve necessariamente ser constituída de tal modo que ela lida com o coração e a fantasia” Hegel, HW I, p. 37

${ }^{243}$ Idem, p. 19.

${ }^{244}$ Cf. Beckenkamp, J. O Jovem Hegel, Formação de um sistema pós-kantiano, p. 44. 
como fornecendo um princípio ético que mantém a mesma cisão e dominação que ele recusava nas religiões positivas, porém agora instaladas na interioridade do homem. Para um princípio ético que exclui toda motivação para a ação moral que não seja o próprio respeito à lei, razão e sensibilidade encontram-se necessariamente separadas. E a unidade aparente da lei estabelecida pela autodeterminação do sujeito surgirá então, aos olhos de Hegel, como fornecendo uma unidade meramente conceitual e abstrata que se distingue da unidade viva em que essas instâncias se encontram concretamente unificadas. Essa “crise do pensamento", que se caracterizará pelo afastamento do horizonte kantiano, testemunha o nascimento daquilo que se chamará propriamente de filosofia hegeliana ${ }^{245}$. A verdadeira religião, sobre a qual Hegel escreve em Frankfurt, não será mais considerada sob a ótica da autonomia e autodeterminação da vontade como em Berna, mas orientada sobretudo pela concepção de liberdade como unidade dos aspectos sensíveis e racionais no homem, uma espécie de unidade (não dominação) do sujeito ético com o sujeito natural. E o problema da relação entre reflexão e vida tornar-se-á ainda mais premente, pois tratará, precisamente, da possibilidade de exprimir a unidade destas dimensões enquanto unidade das instâncias sensível e racional do homem.

O que nos interessa em especial nesse período de transição é sobretudo observar como aí se apresentam progressivamente as deficiências de um pensar reflexivo, um pensar do entendimento, na tarefa de apreensão desta unidade viva, relegando desta maneira ao âmbito da religião aquilo que o conhecimento não encontra meios para realizar em seu próprio domínio. A dinâmica própria da vida permanecerá, ao longo de todos os escritos desse período, como algo inapreensível (unbegreiflich) para o pensar reflexivo, que ainda impera sobre toda forma de expressão (Ausdruck), e sua apreensão apenas poderá ser pressentida pelo sentimento (Gefühl) e pela fé (Glaube). A relação entre reflexão e vida em Frankfurt passa, dessa forma, a ser abordada principalmente através da oposição entre a unidade enquanto processo já dado na vida, e a unidade abstratamente produzida do conceito, produto da reflexão, que não parece conseguir jamais corresponder àquela "amigável ligação", senão exercendo uma dominação (Herrschaft) que elimina toda forma possível de relação viva.

${ }^{245}$ Bourgeois, B. Hegel a Francfort, ou Judaïsme - Christianisme - Hegelianisme, p. 22. 
“Conceituar é dominar. Vivificar os objetos é torná-los Deuses" (HW I, p. 242) escreve Hegel nos Esboços sobre Religião e Amor (1797/1798), pretendendo com isso evidenciar a distância entre uma relação de unidade viva de sujeito e objeto, expressa pelo termo "divino" (Göttliche), e uma relação em que haveria domínio de um dos termos sobre o outro. "Uma divindade é sujeito e objeto ao mesmo tempo, da qual não se pode dizer que seja sujeito em oposição a objetos, ou que tenha objetos" (HW I, p. 242). A figura do conceito, assim como a atividade reflexiva que o constitui, incorpora uma relação de dominação em relação à multiplicidade viva que pretende forçadamente unificar, e tem por resultado apenas uma unidade abstrata que, no âmbito da moralidade, expressa a positividade de um dever (Sollen) que se impõe. Em diretas influência de Hölderlin e o círculo de Homburg, a idéia de instituir uma nova religião surge da necessidade de reconhecer uma unidade em que nenhuma forma de dominação se estabeleceria entre as instâncias sujeito e objeto, seja a dependência do sujeito em relação ao objeto ou temor diante dos objetos e a fuga para a interioridade do sujeito, "temor da união" (Furcht der Vereinigung) ${ }^{246}$. A nova religião teria assim por objeto a relação livre do subjetivo com o objetivo, dos homens e do divino e, em oposição às formas históricas vigentes de religiões positivas em que a liberdade se encontra negada, a religião deve ser pensada, segundo Hegel, como o "livre culto da divindade" (freie Verehrung der Gottheit) (HW I, p. 241). Essa liberdade no plano religioso tem de espelhar a mesma liberdade da relação entre as instâncias internas ao próprio homem, de modo que por divindade Hegel entende também a união entre a liberdade e a natureza no homem, verdadeiro objeto de uma religião ideal.

Dessa forma, a crítica que se restringia à positividade da religião objetiva é estendida a uma crítica mais ampla que incide tanto sobre o modelo de síntese teórica apresentado pela filosofia kantiana, síntese do conceito, síntese abstrata do entendimento - que mantém o sensível dominado (contraposto) -, assim como sobre o modelo de síntese prática proposto pela filosofia de Fichte, uma síntese da razão concebida enquanto

${ }^{246}$ Sobre a influência de Hölderlin em Hegel na formação de seu pensamento filosófico, ver Henrich, D. Hegel im Kontext, 23-30, 61-72. A idéia de uma instituição de uma religião está diretamente ligada à divinização dos objetos, através de sua vivificação pela imaginação. $\mathrm{O}$ tema de uma nova religião e a relação entre uma "mitologia da razão" com a imaginação estão na base dos programas do idealismo alemão, como se pode depreender do chamado Mais antigo programa de sistema do idealismo alemão. (HW I, pp. 234-36) 
um Eu, através da qual uma unidade deve ser atingida por meio de uma atividade prática que, partindo da atividade consciente, deve extinguir gradualmente toda objetividade (não-eu). “As sínteses teóricas, escreve Hegel, tornam-se inteiramente objetivas, inteiramente contrapostas ao sujeito. A atividade prática aniquila [vernichtet] o objeto e é inteiramente subjetiva" (HW I, p. 242). Em ambos os casos vemos a perpetuação da contraposição entre subjetivo e objetivo, de onde necessariamente provém uma forma de dominação de um dos termos, ao invés do divino enquanto sujeito e objeto ao mesmo tempo.

Vemos assim Hegel empenhado nesses fragmentos em elaborar uma unificação que não resulte em uma nova contraposição dos termos que se pretendia unificar e em que, portanto, não se mantenha mais a relação entre dominante e dominado que se segue a toda forma insatisfatória de união. É a partir desta necessidade que Hegel pensa a unidade produzida pelo amor (Liebe) como uma forma de união que está para além da aniquilação do campo objetivo por parte do sujeito, assim como da dependência subjetiva em relação aos objetos, pois não há aí mais termos separados que possam se contrapor. "Somente no amor se é um com o objeto, não se domina, nem se é dominado" (HW I, p. 242). Com o amor encontramos o primeiro grande ideal de unificação, que ultrapassa o âmbito da relação finita entre partes que se limitam reciprocamente, estabelecendo uma unidade viva de sujeito e objeto. Em oposição à unidade fornecida pelo entendimento, que apenas reúne através do conceito termos de antemão fixados como distintamente separados, a verdadeira unificação do amor tem como horizonte de sua união a infinitude (Unendlichkeit), na medida em que "ela não é nada limitante, nada limitada, nada finita" (HW I, p. 246). No sentimento do amor, amante e amado estão de tal forma unificados que se supera as restrições e limitações finitas das relações próprias às relações conceituais e cognitivas estabelecidas reflexivamente; aquele que ama e o amado não estão mais na mesma distância que um objeto está para um sujeito no processo reflexivo de conhecimento, nem naquela distância própria de uma lei em relação ao domínio sobre o qual legisla. "O amor ele mesmo não exprime nenhum dever (Sollen), ele não é nenhum universal contraposto a uma particularidade, mas unicidade do espírito, divindade [Göttlichkeit]. Amar a Deus é sentir-se no todo da vida sem restrições, na infinitude" (GCh, HW I, p. 363). 
Importante ressaltar como a união promovida no amor é sempre pensada a partir da idéia geral da vida, isto é, enquanto um sentimento que diz respeito apenas aos viventes (Lebendigen), um sentimento da unidade da vida através da união entre dois viventes. É apenas através da união no amor que os viventes podem ser reconhecidos como tais, pois se não estiverem vinculados em uma relação viva, perdem imediatamente o caráter de vivente e passam a ser elementos mortos unidos em uma universalidade abstrata e também sem vida. A relação entre viventes no amor é uma relação entre semelhantes, na qual não há predomínio de um dos lados. "Verdadeira união, amor autêntico ocorre apenas entre viventes que se igualam em potência e são viventes absolutamente um para o outro, e de nenhum lado são mortos que se contrapõe" (HW I, pp. 245-6).

O sentimento do amor permite ao vivente o acesso ao todo da vida, reconhecendose através do outro vivente em sua unidade com ela. Em outras palavras, o amor é um sentimento no qual a vida está em relação consigo mesma através da passagem pelo outro, uma unidade que passa pela diferença, de forma que quando se diz que o amor é um "sentimento do vivente" deve-se compreender isso a partir da simultaneidade do genitivo subjetivo e objetivo, isto é, enquanto um sentimento da viva do vivente experimentado pelo vivente ${ }^{247}$. Com essa forma de união no amor, Hegel esboça um princípio fundamentalmente religioso, pois do mesmo modo que o objeto da religião ideal é pensado como união viva de instâncias que não predominam uma sobre a outra, união em que se realiza uma superação da vida finita na unidade com o divino, a síntese no amor também representa o ultrapassamento das determinações finitas e restritivas do vivente. É por isso que podemos reconhecer, de acordo com M. Baum, que Hegel apresenta no Die Liebe os contornos de uma "filosofia da religião antropologicamente fundada" ${ }^{248}$, pois o que se vislumbra no sentimento do amor nada mais é do que a própria unidade dos âmbitos subjetivo e objetivo no todo da vida, um absoluto que representa o próprio ideal do divino. Esse "monismo da vida" apresentado pela "religião do amor" ${ }^{249}$, surge como forma de estabelecer a unidade viva do finito e do infinito, a que Hegel chama de divino, unidade esta que não pode ser hipostasiada em uma esfera

${ }^{247}$ Cf. Baum, M, Die Entstehung der Hegelschen Dialektik, p. 40.

${ }^{248}$ Baum, M, op. cit, p. 37.

${ }^{249}$ Baum, M, op. cit, p. 42. 
transcendente ao próprio vivente sem com isso desfazer os laços de união que constituem esse ideal. Sendo "o amor mais forte que o temor" ${ }^{250}$, a religião fundada nesse sentimento parece superar definitivamente a positividade expressa em uma lei imposta de fora, assim como aquela representada por um princípio moral que ordena a exclusão de uma parte constitutiva da vida do homem.

O que, porém, é fundamental nesse fragmento, e representa um passo importante na direção da compreensão da dinâmica própria da vida e sua relação com a reflexividade, é o fato de que a unidade promovida no sentimento de amor apresenta a vida, pela primeira vez, como um processo de desenvolvimento em direção a uma unidade a ser conquistada a partir da passagem pela separação (Trennung). Encontramos aqui o prenúncio da unidade dialético-especulativa da fillosofia hegeliana madura ${ }^{251}$.

"No amor, escreve Hegel, esse todo não está contido como na soma de muitos particulares, de separados [Getrennte], nele se encontra a própria vida, como uma duplicação de si mesma e unicidade da mesma [Einigkeit desselben]" (HW I, p. 246).

Essa duplicação da vida é precisamente a passagem que ela realiza na diferença figurada pelos viventes que, separados, retornam à unidade formada pelo amor ${ }^{252}$. A vida é então reconhecida como um desenvolvimento que inclui três etapas: unicidade não desenvolvida, formação e a unicidade completa, desenvolvida. "A partir da unicidade não-desenvolvida, a vida percorreu, através da formação [no amor], o círculo de uma unicidade completa" (HW I, p. 246). Enquanto um processo em desenvolvimento, a vida

${ }^{250}$ HW I, p.247. "O amor, enquanto unificação essencialmente bipolar, amálgama e não dominação, fornece a alternativa ao respeito e à reverência que o homem incompleto e finitizado tem pelo infinito enquanto algo que está fora dele e que o aguarda no além". Lima, E. C, Crítica da moral deontológica no jovem Hegel, p. 96.

251 "A vida é a primeira forma na qual a substância é concebida como sujeito, sendo pois a primeira encarnação da liberdade. E é o primeiro modelo de uma real unificação de opostos, a primeira encarnação da dialética". Marcuse, H. Razão e Revolução, pp.43-44.

${ }^{252}$ A auto-suficiência do vivente, seu princípio de vida próprio que permite que ele simultaneamente se distinga do todo da vida se resume à sua finitude, ao fato de que um vivente pode morrer, apartando-se, assim, da unidade formada pelo todo da vida. "Weil die Liebe ein Gefühl des Lebendigen ist, können Liebende sich nur insofern unterscheiden, als sie sterblich sind, als sie diese Möglichkeit der Trennung denken, nicht insofern als wirklich etwas getrennt wäre, als das Mögliche mit einem Sein verbunden ein Wirkliches wäre (...). Liebenden haben Selbstständigkeit, eigenes Prinzip, [das] heißt nur: sie können sterben”. (HW I, p. 246). 
deve percorrer um caminho que passa pela separação e retorna à sua unidade que, nessa formação, contém agora a passagem pelo outro. Trata-se da primeira aparição do termo Reflexion na obra de Hegel já contendo o pleno sentido de separação e aproximado à idéia de formação (Bildung) e desenvolvimento (Entwicklung) - aspecto de fundamental importância que nos escritos de Jena culminará no reconhecimento pleno da reflexão como momento necessário de mediação realizado pela totalidade a ser conhecida ${ }^{253}$.

Vemos aqui, por conseguinte, o primeiro passo determinante no sentido de uma superação da oposição ainda presente entre reflexão e vida e que caminha na direção de uma concepção de 'reflexão da vida' como duplicação de si, enquanto momento de um processo da própria vida no tornar-se consciente de si mesma. A idéia de uma autoconsciência como resultado da reflexão surge no período de Frankfurt a partir desta oposição entre a "unicidade não desenvolvida e sem consciência" e aquela unidade da vida que se "reencontra" (wiederfindet) e ganha consciência ${ }^{254}$. O desenvolvimento da vida no qual ela se torna consciente de si mesma é pensado como sendo a passagem pela separação - consciência é sempre a consciência de um outro em relação a si -, contraposição que é instaurada pela reflexão, mas que é de antemão relativizada ao todo da vida e não tornada, ela mesma, absoluta numa espécie de "contraposição infinita" 255. Hegel apresenta essa dinâmica da vida que inclui a passagem pela contraposição no seguinte trecho do fragmento sobre o amor:

"À̀ unicidade não-desenvolvida contrapunha-se a possibilidade da separação e o mundo; no desenvolvimento [Entwicklung] a reflexão produziu cada vez mais contraposto, que era unido no impulso satisfeito, até que ela contrapôs ao homem a totalidade do próprio homem, até que o amor suprime [aufhebt] a reflexão em completa ausência de objeto [völlige Objektlosigkeit], rouba do contraposto todo caráter de um estranho e a vida encontra a si mesma sem mais carências" (HW I, p. 246).

253 “A concepção da vida como este 'círculo de uma unidade completa', que inclui necessariamente a passagem para a separação e a contraposição, constitui um passo decisivo na formação do pensamento especulativo de Hegel, pois nela é dado o devido espaço para a reflexão, que pode doravante ser investigada como um momento essencial do processo global que constitui a totalidade absoluta (por enquanto tratada como vida)". Beckenkamp, J. Op. cit, p. 166.

${ }^{254}$ Hegel, GCh, HW, p. 386 e p. 346, respectivamente.

${ }^{255}$ Hegel, Systemfragment, p. 420. 
A unidade promovida pelo sentimento do amor é, portanto, de outra natureza do que aquele "esforço infinito" (unendliches Streben) que tende à unidade, do qual a Wissenschaftslehre de Fichte nos fala ${ }^{256}$, o qual, ao invés dissolver a diferença unificando efetivamente os opostos como faz o amor, deve (soll) aniquilar o que é estranho ao Eu através de uma negação do campo objetivo ${ }^{257}$. O amor, ao contrário, suprime as cisões inseridas pela reflexão, e retira das contraposições a fixidez que lhes mantinha enquanto estranhas à unidade da vida, reconduzindo-as a ela. Essa nova unidade, contudo, não é aquela pura indiferença, em relação à qual a separação se contrapõe, mas a unicidade desenvolvida a partir da diferença: "no amor o separado ainda é, mas não mais enquanto separado, [mas] enquanto unido, e o vivente sente o vivente" (HW I, p. 246). Trata-se de um primeiro esboço da concepção hegeliana de Aufhebung que em seu movimento mantém subsistindo, na qualidade de suprimidos, os termos em que se constituía a separação ${ }^{258}$.

No entanto, se a unidade promovida pelo amor permite a absorção da reflexão na vida, isto é, torna efetiva a separação enquanto um momento interno da própria vida, a unidade alcançada se revela ainda não sendo uma união plenamente satisfatória, pois ainda mantém todo um âmbito intacto e para além "da esfera particular constituída no laço do amor" 259. "O amor, escreve Hegel, reata pontos em momentos, mas ainda se mantém nele o mundo, o homem e sua dominação" (HW I, p. 303). O que Hegel tem aqui em vista em relação à insuficiência da união do amor são dois aspectos diretamente vinculados: em primeiro lugar, a limitação do sentimento amoroso à relação restrita dos viventes que amam, deixando a união amorosa isolada em relação ao mundo objetivo. Em segundo lugar, a insuficiência do elo amoroso no desenvolvimento de uma união completa se deve à própria natureza sentimental do amor, que, enquanto um sentimento (Empfindung), não pode ascender a nenhuma forma de objetividade, e acaba por manter assim, à distância de um abismo intransponível, o âmbito objetivo próprio à

${ }^{256}$ Fichte, Grundlage der Wissenchaftslehre, 1794, GA I,2, p. 397.

${ }^{257}$ Cf. Hegel, DS, p. 68.

${ }^{258}$ Cf. Hegel, PhG, HW III, p. 94.

259 "Tanto a disposição moral como o amor deixam intacto um separado, contraposto seja à moralidade, como impulso não integrado e não integrável à ordem moral, seja ao momento de união que é o amor, como o resto do mundo, que não participa da esfera particular constituída no laço do amor. Do ponto de vista do princípio da união, ambos são deficientes, apesar de constituírem já etapas no retorno à união”. Beckenkamp, J. Op. cit, p. 157. 
reflexividade. "O próprio amor é apenas sentimento, não unido à reflexão" (GCh, HW I, p. 370) e, enquanto tal, é incapaz de dar uma forma a essa unidade viva que não seja a imediata relação amorosa. A ausência de reflexividade (mediação) do amor impossibilita o reconhecimento dos momentos separados no interior da unidade da vida, isto é, não concede espaço à objetividade; e é por isso que Hegel afirma que o amor deve ser complementado pela religião:

"Mas o próprio amor ainda é uma natureza incompleta: nos momentos do amor venturoso não há espaço para objetividade. Mas toda reflexão suprime o amor produz novamente a objetividade e com ela começa novamente o domínio das limitações. O religioso [Religiöses] é, portanto o $\pi \lambda \eta ́ \rho \omega \mu \alpha$ do amor (Reflexão e amor unidos, pensados como ligados)" (GCh, HW I, p. 370).

Portanto, se a moralidade, com seu princípio de autodeterminação, é capaz de superar a dominação exercida por uma instância transcendente, e o amor, por sua vez, de superar também a forma da lei interiormente reconhecida, ultrapassando assim os limites restritos da moralidade e as formas de dominação na interioridade do sujeito, "o amor ainda não é religião" (GCh, HW I, p. 364), e a união através dele constituída ainda não pode receber a forma contemplável da objetividade, a forma de um objeto infinito no qual estariam unidos, de maneira viva, as multiplicidades e contraposições inscritas no desenvolvimento da vida.

"Esse amor é um espírito divino, mas ainda não é religião. Para que se torne uma religião, ele deveria simultaneamente se apresentar em uma forma objetiva. Ele, um sentimento, algo subjetivo deveria se fundir com o representado, com o universal, e com isso obter a forma de um ser digno e capaz de oração" (GCh, HW I, pp. 405-6).

O que Hegel quer dizer com isso é que o amor ainda está restrito ao âmbito subjetivo e que, na qualidade de um sentimento, não se une com o objetivo senão na medida em que é complementado pela religião. Esta surge justamente da "necessidade suprema do espírito humano (...) de unir o subjetivo e o objetivo, a sensação e a sua exigência de objetos, unir o entendimento através da fantasia em um belo e em um Deus" 
(GCh, HW I, p. 406). O que a religião permite é, pois, a "apresentação dessa unicidade” (Darstellung dieser Einigkeit), que através somente do amor não pode ser contemplada, assim como também não pode ser objeto de um conhecimento (Erkenntnis) que instaura nessa unidade separações que simultaneamente a destroem.

Dessa forma, a unidade internamente diferenciada da vida, entendida como processo e realizada no sentimento do amor, fica restrita ao âmbito da religião e, isso enquanto um objeto indizível, já que não há palavras ou expressões que preservem em união o todo da vida. "O amado não nos é contraposto, ele é um com nosso ser; vemos apenas a nós mesmos nele - e, todavia, ele não é novamente nós - um milagre que não podemos compreender" (HW I, p. 244) ${ }^{260}$. Esta incompreensibilidade, reduto da fé e do sentimento religioso, é justamente o signo da ainda não presença de uma forma de pensar que esteja para além dos pressupostos do pensamento reflexivo. E se o sentimento do amor permite ver que a reflexão é incorporada ao processo próprio da vida, Hegel ainda não dispõe de um pensar que possa apreender essa relação de contraditórios em uma unidade, permanecendo algo da ordem do milagre, que toda expressão deve fracassar na tentativa de abarcar.

É exatamente essa falência da reflexão em dizer o ser da vida em sua dinâmica própria que Hegel aborda nos escritos reunidos sob o nome de $O$ espírito do cristianismo e seu destino, nos quais podemos perceber uma ainda maior hesitação da linguagem que não pode dizer essa relação sem simultaneamente destruí-la, o que por si só se constitui enquanto exigência de uma nova "linguagem", não reflexiva (entendimento), para expressar esse princípio próprio de unificação expresso pela vida. Nesses textos, Hegel busca as origens da positividade da religião cristã no espírito do judaísmo de onde ela provém, analisando figuras que inauguram diversas experiências de separação na relação harmônica do homem com a natureza, assim como na relação do homem com o divino, tal como a do patriarca Abraão, cujo ato de criação de uma nação residiria justamente na instauração da separação (Trennung) na relação viva com sua própria terra e vizinhança, arrancando (zerreißen) assim o "elo da convivência e do amor" através do qual se unia. À crítica ao espírito do judaísmo encontramos associada uma censura severa ao princípio de moralidade kantiano, cuja idéia de lei, segundo Hegel, implicaria a mesma separação que

${ }^{260}$ O grifo é de nossa autoria. 
a forma do mandamento na lei mosaica. Vemos nesse momento a relação entre reflexão e vida ser pensada a partir da oposição entre vida, como um universal concreto, um todo dinâmico que incorpora em seu interior a diferença, a passagem pela particularidade e, de outro lado, a figura da lei (Gesetz) sob a marca do conceito, como um universal abstrato artificialmente forjado que mantém a multiplicidade a si contraposta. Nesse sentido, todas as sínteses, teóricas e práticas, elaboradas pelas formas conceituais e reflexivas postas em marcha pela filosofia kantiana, tornam-se o alvo privilegiado das críticas de Hegel, que agora busca encontrar aquela união do amor no verdadeiro espírito do cristianismo incorporado na figura histórica de Jesus. Trata-se, pois, da tentativa de pensar em conjunto a unidade promovida no amor e sua contemplação em uma figura (Gestalt), isto é, a unidade do amor e da reflexão - "amor figurado" (gestaltete Liebe) - através do complemento religioso (GCh, HW I, pp. 407-08).

Logo nos primeiros parágrafos do Espírito do Cristianismo Hegel apresenta uma comparação da religião cristã, e em especial o sermão da montanha feito por Jesus e narrado no evangelho de Matheus, com a filosofia moral kantiana, tendo como horizonte a crítica à rígida separação da pureza moral das inclinações que impera na filosofia prática de Kant. O núcleo dessa comparação é novamente articulado pelas noções de dominação, servidão e obediência, assim como pelas conseqüentes restrições que essas formas de relação implicam no todo da vida, um núcleo organizador de todos os escritos de Hegel desse período. As leis práticas apresentadas pela filosofia kantiana são nesse escrito associadas à lei religiosa judaica e pensadas a partir da idéia de mandamento (Gebot), como uma obrigação que se exerce sobre a particularidade de uma vontade que está submetida aos apetites sensíveis. O horizonte geral da crítica é a situação de "dilaceramento do homem" (Zerrissenheit des Menschen) dividido em duas metades - e a moral kantiana, que em Berna era vista como sendo uma forma de pensar a superação do espírito judaico, é agora vista como de espírito semelhante ao dele, ou seja, como signo mesmo da positividade e da mera legalidade.

Ao imperativo categórico kantiano, enquanto forma da lei e critério da moralidade, são agora contrapostos os ensinamentos de Jesus que não assumem a forma de uma obrigação que exige obediência, mas antes a própria supressão da forma lei. 
"Imediatamente voltado contra leis mostra-se esse espírito de Jesus elevado acima da moralidade no sermão da montanha, que é uma tentativa exercida em muitos exemplos de leis, de retirar o legal das leis, a forma de leis, e que prega não o respeito pelas mesmas, mas mostra aquilo o que as preenche e, contudo, as suprime enquanto lei, e é assim, portanto, algo mais elevado do que a obediência em relação às mesmas e as torna desnecessárias" (GCh, HW I, p. 324)

O núcleo da censura feita por Hegel à moralidade - e aqui é sempre a filosofia moral kantiana que ele tem como horizonte - é que sua lei nada mais é do que um conceito universal que se opõe à efetividade dos impulsos naturais e, por isso, exprime um dever (Sollen), um mandamento, exercendo assim a positividade de uma "mera legalidade"; pois a ação é exigida pelo mero respeito a uma lei que subjuga a multiplicidade das inclinações a ela contraposta ${ }^{261}$.

Em oposição a esse conceito que se expressa como um dever e tem o caráter de obrigação (Pflicht), Jesus apresentaria um mandamento em um outro sentido, em que o conceito - denominação geral de toda forma de universalidade -, embora permanecendo ainda uma "forma estranha à vida", é considerado como uma conseqüência dela, sendo a vida pensada e expressa enquanto um universal, e nesse sentido, o conceito sendo uma derivação da vida e não uma restrição sua. Nesse sentido, a vida, expressa como universal através do conceito, se diferencia bastante do universal expresso no mandamento que obriga (Pflichtgebot) e que "reside na contraposição do conceito e do real", isto é, enquanto um conceito que se contrapõe à vida (GCh, HW I, p. 324). Pois se a vida mesma for concebida como tendo a dinâmica de se individualizar e organizar em diversos mandamentos, estes não serão mais concebidos como sendo a ela contrapostos, separados da vida, mas sim como uma "modificação da vida" (Modifikation des Lebens), uma contração da totalidade em formas particulares (mandamentos) que a ela novamente retornam ${ }^{262}$.

Hegel apresenta através da idéia de "modificação da vida" a própria dinâmica da totalidade da vida e sua relação com a lei, sem fazer da universalidade expressa pela

\footnotetext{
261 "Moralidade é, de acordo com Kant, a subjugação [Unterjochung] do singular ao universal, a vitória do universal sobre seu singular contraposto". Hegel, HW I, p. 299.

${ }^{262}$ Cf. Görland, I, Die Kantkritik des jungen Hegel, p. 9.
} 
última uma "uma universalidade morta" (HW I, p. 303) e abstrata, à qual associa a lei moral kantiana: "A razão prática de Kant é a faculdade da universalidade, isto é, a faculdade de excluir [...]. O excluído não é um suspenso [aufgehoben], mas um separado, ainda subsistente.” (HW I, p. 309). Segundo Hegel, Jesus contribuiria através do oferecimento um $\pi \lambda \eta ́ p o \mu \alpha^{263}$, um “complemento da lei” que está para além da oposição entre a obrigação e as inclinações que encontramos na formulação moral kantiana. Tratase do reconhecimento da unidade da vida como um universal concreto, união que supera a contraposição da universalidade do mandamento com as particularidades das inclinações naturais, de modo que toda forma de legalismo, dominação externa ou interna, se encontra superada ${ }^{264}$. Esse complemento não é, contudo, aqui compreendido como um simples acréscimo do lado impulsivo do homem ao dever abstrato da lei, mas antes como a exigência de pensar ambos os termos a partir da unidade indissociada em que se encontram.

"A concordância entre a inclinação e a lei é de tal maneira que lei e inclinação não são mais diversas; e a expressão 'concordância da inclinação com a lei' se torna totalmente inadequada, pois nela lei e inclinação aparecem ainda como particulares, como contrapostos e facilmente poderia ser entendido um auxílio da disposição moral, do respeito pelo dever e do ser-determinado da vontade pela lei através da inclinação diversa disto; e já que os [termos] que concordam são diversos, também a concordância seria somente contingente, somente a unidade de estranhos, um pensado" (GCh, HW I, pp. 326-27).

263 O termo empregado por Hegel é retirado do sermão da montanha feito por Jesus, segundo o evangelho de Matheus (Ev. Mat. 5, 17). Em seus textos de Berna, Hegel já emprega essa mesma expressão para indicar a superação da lei positiva dos judeus através da moralidade proposta pela filosofia kantiana. Em Frankfurt, todavia, a idéia de um "complemento da lei" é ela mesma pensada como estabelecendo uma crítica à moralidade kantiana na medida em que vai de encontro com a idéia de uma 'objetividade' da lei moral como algo dado e exige a concordância da lei e das inclinações, o que ultrapassa a perspectiva kantiana característica dos escritos de Hegel do período de Berna. Cf. HW I, p. 309. Ver também: Fujita, M, Philosophie und Religion beim jungen Hegel, p. 84-5; Görland, I, Die Kantskritik der jungen Hegel, p. 9.

264 "Portanto, Jesus é visto como arauto de um ideal ético que é totalmente diverso não apenas do puro legalismo, mas também da remissão da validade da lei à obrigação moral erigida pela autonomia da razão, a qual somente suprime a positividade parcialmente e, mais exatamente, na medida em que interioriza a dominação do particular pelo universal" Lima, E. C, Crítica da moral deontológica no jovem Hegel, p. 109. 
Hegel está tentando dizer aquilo que sua linguagem ainda não permite; hesita em falar em concordância (Übereinstimmung) da inclinação e da lei na totalidade da vida, uma vez que, com isso, ambos os termos dessa relação permaneceriam fixados como termos diversos; e a unidade que se quer exprimir está sempre já perdida no processo de somar termos cindidos. A inadequação da expressão em relação à unidade contraditória e indissociável da vida será cada vez mais sentida e permanecerá ainda insuperável no enquadramento em que Hegel se encontra em Frankfurt, em que toda expressão está presa ao âmbito reflexivo, não havendo um dizer que apreenda esta unidade dinâmica própria da vida sem subordiná-la novamente ao âmbito do pensamento que mantém a distância entre estranhos ${ }^{265}$.

Todo esforço de dizer a vida parece ser inadequado a ela e, a menos que a própria linguagem seja repensada a partir de uma nova orientação, a totalidade contraditória da vida permanecerá sempre além de uma expressão adequada. Essa é a razão pela qual em Frankfurt o absoluto, a "vida divina" (gottliches leben), ou a unidade viva do finito e infinito que, para Hegel a doutrina cristã da trindade tem em seu espírito por exprimir, termina por ficar relegada ao campo da não-expressão, do sentimento e da fé. Para o pensamento reflexivo, característico do entendimento, não há como expressar o divino, de modo que a infinitude é por ele posta na dimensão do mistério, do não-saber: "sobre o divino apenas pode-se falar com entusiasmo" (GCh, HW I, p.372).

Nessa hesitação da linguagem, lócus em que se encontra o germe da especulação hegeliana, é que surge efetivamente a necessidade de uma linguagem que não esteja de antemão presa ao sentido restritivo das categorias da reflexão, que possa empregar suas palavras sem compartilhar necessariamente de seus pressupostos, algo que permanecia até então vedado ao horizonte de Hegel ${ }^{266}$. Ilustrativo nesse sentido é a menção que Hegel faz ao início do evangelho de João, no qual encontra uma seqüência de proposições de caráter tético, expressas na "mais simples linguagem da reflexão", e que, segundo Hegel, exigiriam “espírito” para serem apreendidas naquilo que expressam:

265 "Por mais violentamente que tenha combatido, nesse momento, as rígidas oposições da Reflexão, Hegel, de fato, assumia os pressupostos desta última”. Lebrun, G. A Paciência do Conceito, p. 40.

266 "Nessa época, porém, não se concebia qual discurso poderia substituir o discurso reflexivo e como o Saber poderia ser outra coisa que não conhecimento, isto é, separação". Lebrun, G. $O p$. cit., p. 40. 
"No princípio era o Logos, o Logos estava com Deus, e Deus era o Logos; nele estava a vida. Mas estas proposições têm apenas a aparência enganosa de juízos, pois os predicados não são conceitos, universais, tais como a expressão de uma reflexão em juízos contém necessariamente. Mas os predicados são eles mesmos novamente entes, viventes; nem mesmo essa simples reflexão [einfache Reflexion] é hábil para exprimir com espírito o espiritual [Das Geistige mit Geist auszudrücken]" (GCh, HW I, p. 373).

Quando aquilo que deve ser expresso é da ordem de uma relação viva, de uma unidade não abstrata de dois viventes, que na medida em que se relacionam se diferenciam, a "linguagem da reflexão" não tem meios para fazê-lo. Ao invés de uma forma de pensar organizada a partir do entendimento, seria necessário um pensamento que não estivesse imediatamente colado ao sentido tradicional de juízo. 'Logos' não é aqui um conceito, um predicado universal no qual se subsume o sujeito 'Deus'. A “aparência enganosa de juízos" é inevitável à escuta própria do entendimento, que não pode apreender a unidade viva de dois viventes, Logos e Deus, para além da subsunção de entidades absolutamente distintas cujas extensões diferem. Ambos, "sujeito" e “predicado" são, no entanto, seres concretos, viventes, e isto precisamente na medida em que são "no início" (im Anfang) o mesmo ser ${ }^{267}$. O sentido daquilo que é dito através da "linguagem da reflexão" parece ser, no ato mesmo de dizê-lo, perdido ${ }^{268}$, uma vez que toda forma da expressão, é aqui concebida como sendo do domínio exclusivo da reflexão. “Toda expressão, escreve Hegel, é produto da reflexão e, portanto, pode ser mostrado de cada uma, como algo posto, que com isso - pelo fato de ter sido posto - ao mesmo tempo um outro não é posto, é excluído" (SF, HW I, p. 422). A viva divina, a sua unidade contraditória em que são postos simultaneamente os opostos, nada mais é, para o entendimento, do que uma contradição, um algo além de possibilidade de expressão,

${ }^{267}$ Em Glauben und Sein, Hegel, em manifesta influência de seu amigo Hölderlin, aborda o caráter de unificação (Vereinigung) do sujeito e do predicado expresso pela cópula em todos os juízos, indicando como o Ser (Sein) é a própria expressão desta unidade que, todavia, por não poder ser adequadamente apresentada na forma de um juízo que sempre implica separação, apenas pode ser objeto de fé. "Vereinigung und Sein sind gleichbedeutend; in jedem Satz drückt das Bindewort ,ist' die Vereinigung des Subjekts und Prädikat aus - ein Sein; Sein kann nur geglaubt werden....”, HW I, p. 251.

${ }^{268}$ Cf. Baum, M, Die Entstehung der Hegelschen Dialektik, p. 62. 
"pois tudo o que é expresso sobre o que é divino na forma da reflexão é um contra-senso [widersinnig]" (GCh, HW I, p. 373).

O que Hegel apresenta aqui como exigência é fundamentalmente a reconfiguração do domínio do dizível, de modo a permitir a expressão da infinitude sem esvaziar, em uma "apreensão carente de espírito" (geistlose Aufnahme) própria ao entendimento, aquilo que naquelas palavras há de espiritual. Portanto, mais do que o abandono definitivo da expressividade, a ainda sutil e não desenvolvida percepção da necessidade de uma reinterpretação do âmbito geral do saber vem à tona como o reconhecimento de que é necessário, não outras palavras, mas uma outra escuta daquilo que a reflexão exprime (separa) e que não pode novamente recolher. Uma tal espécie de reinterpretação da "linguagem da reflexão", que aqui aparece de maneira ainda tímida através da expressão "apreensão com espírito próprio e profundo" (GCh, HW I, p. 373), será a perspectiva central a partir da qual Hegel realizará em Jena a leitura da filosofia kantiana, e que ali receberá o nome de especulação.

Porém, até o final do período de Frankfurt, Hegel ainda está preso aos pressupostos reflexivos da linguagem comum, e a religião, enquanto dimensão na qual se efetiva a relação do finito com o infinito, ainda é o campo privilegiado para "dizer" a vida em seu dinamismo próprio.

"A relação entre o infinito e o finito é certamente um mistério sagrado, pois essa relação é a própria vida. A reflexão, que cinde a vida, pode distingui-la em infinito e finito, e apenas a limitação, o finito considerado por si, fornece o conceito de homem como contraposto ao divino; fora da reflexão, na verdade, ela [a limitação] não se dá" (GCh, HW I, p. 378).

Vemos nessa passagem de central importância como a relação entre reflexão e vida permanece um problema não plenamente solucionado para Hegel em Frankfurt, uma vez que a unidade alcançada entre ambos não consegue obter uma forma satisfatória de expressão, devendo essa unidade permanecer, para o saber, um mistério. A religião é, portanto, considerada enquanto a única dimensão em que a dinâmica própria da vida, o 
absoluto enquanto passagem do finito ao infinito, pode ser experimentado ${ }^{269}$. A reflexão cinde (trennt) a vida, e separa nitidamente o finito do infinito, de forma que a recuperação da unidade figurada da reflexão com a vida permanece uma tarefa impossivel para a própria reflexão e, portanto, para o pensamento conceitual a ela identificado no periodo de Frankfurt. Hegel escreve que a verdade está para além da reflexão, e não há, nesse momento, outra forma de pensar que não esteja circunscrita aos procedimentos da reflexão. Há, conseqüentemente, diferentes domínios que se distinguem nitidamente do ponto de vista ontológico e epistemológico: o domínio daquilo que é cognoscível, objeto de um conhecimento (Erkenntnis) possível e, portanto, da esfera reflexiva (filosofia), e o domínio do que apenas pode ser experimentado através da fé, e permanece um mistério para todo e qualquer pensamento reflexivo (religião).

\section{A reabilitação parcial da filosofia.}

Se, como vimos, o entendimento é colocado em xeque ao se deparar com uma unidade experimentada no sentimento e na fé, não porque esteja diante de algo que está "fora de seu domínio" (außerhalb seines Gebietes) - para o qual os termos mistério e milagre parecem recobrir sem muito problema -, mas sobretudo porque ele mesmo parece exigir simultaneamente a unidade dos diversos que acabara de pôr como distintos de maneira absoluta; se, pois, diante dessa contradição o entendimento parece encontrar seu próprio limite, e com isso seu próprio "desmantelamento" (zerrüttung) e "destruição" (zerstörung) ${ }^{270}$, a identidade mesma entre pensamento e reflexão - verdadeiro pressuposto do entendimento - jamais é colocada aqui em questão. Portanto, não há ainda um campo instaurado para um pensar que esteja submetido à outra ordem do que aquela do entendimento.

269 "Para Hegel, a religião é efetividade [Wirklichkeit] do divino no homem, efetividade que transcende a finitude do pensar e da consciência de si. A religião ultrapassa assim também a filosofia, cujo órgão é a reflexão com suas leis". Düsing, K. Das Problem der Subjektivität in Hegels Logik, p. 69.

${ }^{270}$ GCh, HW I, p. 380. "Diejenigen, die diese absolute Verschiedenheit setzen und zugleich doch fordern, die Absoluten in der innigsten Beziehung als Eins zu denken, heben nicht in der Rücksicht den Verstand auf, daß sie etwas ankündigten, das außerhalb seines Gebietes wäre, sondern er ist es, dem sie zumuten, absolut verschiedene Substanzen aufzufassen und zugleich absolute Einheit derselben; sie zerstören ihn also, indem sie ihn setzen". 
Será a própria tensão de um entendimento que se vê obrigado a ir além de si, sem no entanto poder compreender a fundo a origem dessa necessidade, que irá trazer a filosofia à pauta no final do período de Frankfurt. A filosofia, que esteve sempre associada aos processos reflexivos e, nessa medida, condenada a não poder pensar efetivamente a unidade de contrários, será agora contemplada como a esfera mesma em que o fracasso da reflexão deverá ser tematizado, de modo a, em um segundo momento (apenas em Jena), poder apreender o resultado positivo desse fracasso, trabalho da especulação. Na medida em que Hegel puder contemplar o próprio esforço da reflexão em dizer a vida, e puder apreender a partir do fracasso desse esforço o papel decisivo que cabe à reflexão nessa tarefa - apenas então poderá surgir um novo sentido para a Reflexion, que vá além da "reflexão isolada" ${ }^{271}$ do entendimento, reflexão crítica aos moldes kantianos. É no interior desse embate que podemos situar o nascimento da filosofia hegeliana.

Tal esforço da reflexão é apresentado no fragmento que se convencionou chamar de Systemfragment, último escrito de Hegel ainda morando em Frankfurt. Acerca da importância deste fragmento escreve B. Bourgeois:

"A reflexão filosófica de Hegel começa nelas [folhas salteadas do System-fragment] e tem como afirmação principal que a filosofia é incapaz de realizar o ideal que queria exprimir reflexiva e sistematicamente. (...) A primeira filosofia propriamente técnica de Hegel é a sistematização da impossibilidade de sistematizar, de reunir num todo a vida livre, (que constitui o conteúdo do ideal hegeliano), e a forma reflexiva de uma filosofia sistemática. Proclama a incapacidade da filosofia de em produzir na unidade dos conceitos (pseudo-unidade da reflexão), unidade tão desejada que para Hegel então já estava dada, na vida" (Bourgeois, B, [1986], 2005, p. 386).

${ }^{271}$ O termo "isolierte Reflexion" ainda não aparece em Frankfurt e surgirá apenas em Jena, a partir da exigência de uma distinção entre modalidades de reflexão, em direta relação ao princípio que a conduz, entendimento ou razão. Essa distinção de interpretação da operação da reflexão será o núcleo de nosso próximo capítulo. 
No Fragmento de Sistema encontramos essa "sistematização da impossibilidade de sistematizar" ${ }^{272}$, que está em pleno acordo com o "impulso para a ciência" que Hegel falava em sua carta a Schelling de novembro de 1800, aparecendo aqui enquanto a organização conceitual e reflexiva dos princípios gerais em questão em suas análises acerca da religião ideal e da origem da religião. Essa "tentativa efetiva de fornecer um fundamento teórico para suas investigações até o momento realizadas" 273 leva Hegel a uma ampliação de suas considerações sobre a relação entre o humano e o divino em direção a uma "consideração metafísica da relação entre o finito e o infinito" (HW I, p. 225) mais ampla, como já podíamos reconhecer em marcha desde o Espírito do Cristianismo. Se a unificação alcançada na religião não pode ser conceitualmente expressa devido às insuficiências da reflexão, a própria resistência ao conceito pode ser, por sua vez, conceitualmente analisada e interpretada ${ }^{274}$.

O Systemfragment tem, portanto, uma importância central no processo de reinterpretação da reflexão. Vemos ali Hegel operando com conceitos da reflexão e esmiuçando os seus artifícios, avaliando, ao longo desse processo, os resultados que se podem obter através destas operações que nada mais evidenciam do que o esforço em pensar uma dinâmica que a todo momento resiste em ser apreendida pelos seus conceitos. Significativo, porém, não é apenas essa esquiva constante da vida em relação à reflexão, mas aquilo que resulta do próprio movimento e confronto de suas categorias com o modo de ser da vida. Como veremos, a reflexão encontra, ela mesma, para si mesma, um limite,

\footnotetext{
${ }^{272}$ T. Haering insiste bastante na inadequação da denominação desse fragmento enquanto um 'fragmento de sistema', afirmando não haver ainda em Frankfurt nenhuma "apresentação metódica e unitária dos pensamentos fundamentais de Hegel que abarque toda a realidade" (p. 536), buscando indicar como o fragmento de 1800 segue a mesma linha de exposição e aborda o mesmo "problema fundamental prático-religioso" dos fragmentos anteriores e não uma especial filosofia da natureza, como se poderia interpretar. Cf. Haering, Hegel Sein Wollen und Sein Werk, pp. 536-579. Todavia, a denominação 'Systemfragment' não me parece de todo inadequada, uma vez que o que se revela ali não é propriamente uma apresentação completa e sistemática dos pensamentos de Hegel, mas precisamente, a tentativa de organização reflexiva da problemática da religião ideal, e a conseqüente impossibilidade de formação de um sistema reflexivo, o que justifica seu caráter essencialmente fragmentário.

${ }^{273}$ Fujita, M, Philosophie und Religion beim jungen Hegel, p. 84-5.

274 “O religioso mesmo [Das Religiöse sebst] não é portanto, como Hegel afirma, nenhum conceito, mas precisamente sua incapacidade de ser determinado conceitualmente [Begrifflosigkeit] pode ser esclarecida em uma análise conceitual, assim como o surgimento e necessidade da religião tornados compreensíveis [begreiflich] a partir de uma consideração da natureza que a subjaz”. Baum, M, Die Entstehung der Hegelschen Dialektik, p. 68.
} 
um ponto que não pode ultrapassar sem aniquilar sua própria maneira de proceder enquanto reflexão isolada. Essa experiência reflexivamente vivida será experimentada como uma contradição que apenas poderá ser resolvida por um pensamento que vá além da mera reflexão e das categorias do entendimento que a orientam, isto é, um pensamento que não tome a contradição como um limite absoluto para seu pensar. Em outras palavras, o reconhecimento da deficiência das categorias da reflexão em apreender a vida exigirá uma reconfiguração da própria reflexão a partir de uma perspectiva especulativa.

A novidade principal desse fragmento, portanto, não reside apenas na indicação da limitação da reflexão e de sua linguagem para exprimir o todo da vida, mas sobretudo no esforço em indicar essa limitação através dos artifícios do próprio pensamento reflexivo, algo que aparecerá de modo bem mais desenvolvido na primeira publicação de Hegel em Jena, o Differenzschrift, em que o fazer da reflexão não mais será um obstáculo à expressão e apreensão do absoluto, mas antes um instrumento, um momento necessário para o seu conhecimento. E se a filosofia ainda aparece em 1800 como limitada e incapaz de realizar a tarefa que pretende, seus limites já aparecem sob uma outra luz, que reconhece, ainda que de maneira não totalmente sistematizada, uma tarefa subordinada para a reflexão filosófica.

"Vigora a absoluta contraposição" é a frase inicial que possuímos desse fragmento e que está referida à multiplicidade de formas viventes com que nos deparamos na natureza. Contraposições encontramos na diversidade dos viventes (Lebendigen); diante dos seres vivos, estamos diante de uma multiplicidade infinita que se contrapõe entre si. Enquanto viventes, em sua diversidade, cada individualidade deve ser considerada como uma organização, o que implica numa dupla relação com a vida: por um lado o vivente está a ela unido, "tendo seu ser somente como unificação [Vereinigung]" com essa vida, e, por outro lado, o vivente se contrapõe ao todo da vida, na medida em que é um indivíduo (Individuum), separado dos demais. A vida, portanto, está presente nas partes e no todo enquanto unidade da vida, e o conceito de individualidade (Individualität) é aquele através do qual se expressa a simultaneidade da multiplicidade das formas viventes (indivíduos, organizações) e da unidade da vida.

"O conceito de individualidade encerra em si oposição contra a multiplicidade infinita e ligação com a 
mesma. Um ser humano é uma vida individual, na medida em que ele é algo outro do que todos os elementos e do que a infinitude da vida individual exterior a ele. Ele somente é uma vida individual, na medida em que ele é um com todos elementos, com toda a infinitude da vida exterior a ele. Ele é apenas na medida em que o todo da vida está repartido, [sendo] ele uma parte e todo o restante a outra parte" (SF, HW I, p. 419).

A vida em sua diversidade infinita apresenta em sua dinâmica própria a simultaneidade da ligação e separação dos seus elementos, e Hegel está analisando esse processo através de conceitos maiores da reflexão, unidade e multiplicidade, parte e todo. A mera justaposição do "estar em relação" da parte com o todo, e do "estar em contraposição" das partes entre si e das partes em relação ao todo, não é capaz de apreender o modo de ser do vivente enquanto vivo (lebendig), permanecendo desse modo presa na sua contradição. A exemplificação desta dinâmica pela vida do ser humano não é aqui uma escolha arbitrária; a relação contraditória expressa nessa ligação e não-ligação de todo vivente em relação aos demais viventes e ao todo da vida será abarcada e reconhecida em sua contraditoriedade por essa "vida pensante que considera a vida", pela razão, que, em face às deficiências e ao caráter unilateral de sua reflexão, será capaz de elevar-se para cima dessa contradição no sentimento religioso.

Interessa-nos, em especial, a forma com que a reflexão procede na tentativa de pensar essa dinâmica, e como ela opera segundo uma lógica que lhe é característica, a saber, a da relação entre posição (Setzung), contraposição (Entgegensetzung) e pressuposição (Voraussetzung), lógica esta que acaba por fixar, de maneira absoluta, ambos os termos em relação.

"Pressuposta a vida indivisa, fixada, então nós podemos considerar os viventes como exteriorizações da vida, como expressões cuja multiplicidade - a qual, justamente porque exteriorizações são postas - é ao mesmo tempo posta e, na verdade, é posta enquanto infinita" (SF, HW I, p. 420).

A posição do todo da vida pressupõe a posição da multiplicidade de figuras que dela se destacam e a ela se contrapõem. A partir desta pressuposição, os indivíduos são considerados enquanto uma multiplicidade infinita e nada mais são do que o resultado de 
uma operação de abstração feita pela reflexão, que os "fixa como pontos firmes, subsistentes, em repouso". Se ao invés disto, pela reflexão for pressuposto o próprio vivente - e aqui o próprio homem enquanto ser vivo que reflete é posto como pressuposto de sua reflexão - "então a vida posta fora de nossa vida limitada é uma vida infinita de infinita multiplicidade, de infinita contraposição, de infinita relação" (SF, HW I, p. 420). Temos em ambos os casos uma contraposição da infinitude do todo com a infinitude das partes. Esses dois "infinitos" que se contrapõe são considerados ora a partir da infinita diversidade (diversidade de organizações e indivíduos), ora considerados enquanto unidade infinita, "um todo único, organizado, separado e unificado", que chamamos de natureza (Natur).

O termo natureza é empregado por Hegel já como sendo um termo próprio da reflexão, pois ele representa a própria ação da reflexão no defrontar-se com a vida, a sua submissão aos seus conceitos: "Ela [natureza] é um pôr da vida, pois a reflexão inseriu na vida seus conceitos de relação e separação, do singular subsistente para si, e do universal ligado, conectado, aquele como limitado, este como ilimitado: tornou-a natureza através de uma posição" ${ }^{275}$. A vida infinita, unidade dinâmica de contrários, é transformada pela reflexão em natureza, unidade abstratamente formada na qual os viventes são considerados como pontos fixos distintamente separados. O conceito de Natureza nada mais é, portanto, do que um produto do entendimento, o resultado da relação da reflexão isolada com a vida. Hegel insiste em que o resultado dessa relação é uma forma de dominação que retira da vida o próprio caráter de vivo: “A natureza ela mesma não é vida, mas antes uma vida fixada" (SF, HW I, p. 420). Tal maneira de fixar a vida através da reflexão filosófica, escreverá Hegel em Jena, é característica das filosofias da reflexão e situará a necessidade de uma nova filosofia na tarefa de libertar a natureza "dos maus tratos de que padece nos sistemas kantiano e fichteano" (DS, p. 13).

Toda a argumentação hegeliana no fragmento de 1800 tem em vista mostrar como o procedimento reflexivo de nosso entendimento, preso à "nossa vida limitada", não pode acessar a vida infinita acima das contraposições estabelecidas pelos seus conceitos. Toda posição e pressuposição da reflexão tem sempre seu ponto de partida numa arbitrariedade do entendimento, de modo que a reflexão tem de permanecer exterior à dinâmica que

${ }^{275}$ SF, HW I, p, 420. O grifo é de nossa autoria. 
pretende conceitualizar ${ }^{276}$. No entanto - e aqui reconhecemos a força argumentativa destinada a dar conta da formação da religião -, a operação reflexiva de pressupor não se resume à concomitância entre a posição e a sua contraposição necessariamente pressuposta. Há uma outra pressuposição característica da reflexão em face dos contrapostos, a saber, o pressuposto da unidade de ambos os termos que se contrapõem. Essa unidade pressuposta é a mesma que Kant pensava enquanto unidade hipotética da razão, e que, a partir da necessidade da razão, se tornava objeto de sua especulação. Podemos então dizer que, de maneira semelhante, Hegel quer indicar como é a partir dessa necessidade da razão que nasce o sentimento religioso, buscando contudo ressaltar - e este ponto estabelece uma diferença fundamental em relação a Kant - que a unidade absoluta que está em sua raiz não é aquela unidade hipotética da razão meramente pensada da filosofia kantiana, mas a vida infinita, "que vive como um todo, todopoderosa, ou chame-se a isso Deus, e que jamais é pensando ou considerando, porque seu objeto não traz dentro de si nada refletido, morto" (SF, HW I, p. 421).

A religião não é, portanto, o resultado de uma operação reflexiva que pressupõe uma unidade hipotética para os opostos que seu próprio pensar instaura, mas sim uma necessidade oriunda da própria dinâmica da vida e da falência reflexiva em apreender sua vivacidade. Isso já implica uma transformação significativa da concepção de razão no texto hegeliano, uma vez que esta agora não se identifica de imediato à figura de uma razão abstrata (entendimento) que erige como hipótese uma unidade pensada, mas sim uma razão que reconhece a unilateralidade de seu próprio agir enquanto procedimento reflexivo:

"A razão reconhece ainda o unilateral deste considerar, e esta vida pensante destaca da figura, do mortal, do efềmero, daquilo que se contrapôs infinitamente, daquilo que entra em conflito consigo, o vivo, livre do transitório, a relação sem o morto da multiplicidade e sem aquilo que dela se aniquila, não uma unidade, uma relação pensada, mas antes vida infinita" (SF, HW I, p. 421).

O que a razão agora exige, pois, não é a passagem de um finito posto para um infinito pressuposto, ambos produtos mortos de uma reflexão abstrata, mas a elevação do homem

${ }^{276}$ Cf. Dottori, R. Die Reflexion des Wirklichen, p. 117. 
[Erhebung des Menschen] da vida finita à vida infinita, isto é, religião. Essa elevação da vida finita à vida infinita, que T. Haering considera como sendo um "protótipo religioso da Aufhebung especificamente hegeliana" na medida em que realiza a passagem à uma unidade superior ${ }^{277}$, é a suspensão do ser-parcial (Teilsein) do vivente no todo da vida, a passagem à verdadeira infinitude e não a uma enganadora infinitude, produto abstrato de uma posição (Setzung) da reflexão que se encontra diante da cadeia sem fim de condições e condicionados:

"A elevação do finito ao infinito se caracteriza como elevação da vida finita à infinita, como religião, somente pelo fato de que ela não põe o ser do infinito como um ser através da reflexão, enquanto um ser objetivo ou subjetivo, de tal maneira que ela acrescentasse ao limitado o limitante, [que] conhecesse este mais uma vez como posto, mesmo como um limitado e que, novamente, procurasse o limitante para o mesmo e incorresse na exigência de continuar isto ao infinito" (SF, HW I, p. 423).

O reconhecimento da unilateralidade do agir reflexivo é o sinal de um descolamento, ainda incipiente, da razão em relação ao entendimento, que será levado a cabo e sistematicamente apresentado por Hegel a partir de Jena. Na medida, porém, em que até 1800 está posta a identidade entre pensar e reflexão do entendimento e, portanto, uma vez que a reflexão não pode ter lugar efetivo no conhecimento de uma dinâmica que não é uma unidade abstrata, a razão ainda se revela operando na esfera do entendimento e a reflexão é caracterizada por sua "Unlebendigkeit", de forma que o absoluto, a vida infinita, permanece apenas acessível na esfera da religião ${ }^{278}$. Entretanto, se a razão reconhece a unilateralidade de seu próprio pôr (Setzen) enquanto reflexão e a ela já se apresenta uma exigência de ultrapassamento do nível do entendimento, a razão chega assim a um "conhecimento negativo" da vida, a saber, o "de que a vida não é conhecível através da reflexão" (finita), exigindo de si mesma um movimento crítico de "autolimitação" ${ }^{279}$. Essa negatividade é o patamar mais elevado de conhecimento a que pode se erguer uma razão que compreende a si própria como reflexão crítica: conhecimento

\footnotetext{
${ }^{277}$ Haering, T. Sein Wollen und Sein Werk, I, p. 540.

${ }^{278}$ Cf. Baum, M, Die Entstehung der Hegelschen Dialektik, p. 72.

${ }^{279}$ Baum, M, op cit, p. 73.
} 
finito contraposto a um conhecimento positivo, posto em um além do saber. Em uma palavra: a filosofia de Kant, segundo a leitura que Hegel dela faz.

Vemos em tal configuração o claro desnível que há entre o pensamento (reflexão) e a vida: a mera reflexão opera com conceitos que fixam a vida e sua dinâmica própria em figuras que se separam de tal modo que não podem mais se unir, e é por isso que Hegel associa aqui, novamente, a reflexão com a morte, pois aquilo que se exclui do todo da vida é o morto. Em contraposição a essa maneira de apreensão do entendimento Hegel fala de um recolhimento da multiplicidade numa unidade viva que a tem enquanto figura sua, constitutiva desta unidade. Tal unidade é denominada por Hegel de espírito (Geist), uma relação de unidade viva que se diferencia daquela que se contrapõe ao múltiplo enquanto "diversidade morta, apartada dele" como uma espécie de lei pensada e, portanto, não viva. “O espírito é lei que vivifica [belebendes Gesetz] na unificação com o múltiplo, o qual é assim algo vivificado" (SF, HW I, p. 421). Ou seja, o espírito ou a vida infinita não é um mero pressuposto da reflexão, uma exigência formal para pensar em unidade o todo da vida. Não se trata aqui de uma "notwendige Betrachtungsweise" como era o caso do princípio kantiano exigido pela reflexão na $3^{\mathrm{a}}$ Crítica, e que não podia ultrapassar o "princípio de subjetividade" que lhe regia. Hegel tem claramente aqui em vista mostrar que a vida infinita não é um incondicional subjetivamente exigido pelos condicionados - exigência de uma razão que ainda opera inadequadamente com conceitos da reflexão -, mas sim o todo efetivo a partir do qual toda figura, o próprio ser humano, pode se destacar.

Todavia - e aqui encontramos um passo decisivo na transformação de sentido da reflexão para Hegel - se a unidade a que foi chamada de espírito, esse todo vivo (lebendig) da vida, for concebido apenas como relação (Beziehung), na qual a multiplicidade não é mais tida como tal, mas apenas como "relação ao espírito vivo", dessa relação estaria agora excluída a morte, à qual a vida infinita inevitavelmente se contraporia, indicando a incompletude desta síntese alcançada. O que o espírito vivo enquanto essa unidade viva parece excluir é a própria contraposição (Entgegensetzung), que havia sido constatada por Hegel, desde a primeira linha que nos chegou deste fragmento, como caráter imanente à vida. "Em outras palavras, se o múltiplo é posto somente como órgão em relação, então a própria contraposição está excluída" (SF, HW I, 
p. 422). Trata-se de uma exclusão semelhante àquela que Hegel percebera haver na unidade imediata do amor, que acabava por eliminar toda possibilidade de figuração e, assim, de contemplação dessa unidade.

Hegel se dá conta, pois, de que aquela unilateralidade reconhecida pela razão e através da qual ela organizava a multiplicidade da vida através de suas categorias de relação e cisão, de unidade e universalidade, etc., novamente se apodera da relação viva da vida e a transforma em uma natureza morta, fixada, produto do entendimento, na medida em que, excluindo o morto, a contraposição, pensa a vida unilateralmente apenas enquanto relação, ligação. O que quer dizer que não basta o "sentimento" da contradição que se encontra na base da religião, nem o reconhecimento racional de que a reflexão opera com posições unilaterais, pois ainda assim, a verdadeira infinitude não é alcançada, e da "vida infinita" permanece eliminado o princípio de não-ligação da morte.

"Porém a vida não pode assim certamente ser considerada como unificação, como relação somente, mas tem, ao mesmo tempo, de ser considerada como contraposição. Se eu digo: ela é a ligação da contraposição e da relação, então esta ligação pode, ela mesma, ser novamente isolada, e ser objetado que ela estaria contraposta à não-ligação" (SF, HW I, p. 422).

Evidencia-se aqui, portanto, que a tentativa de apreender e expressar a vida ainda caminhava no nível da reflexão finita, que justamente se mostrava incapaz de pensar ao mesmo tempo a efetividade de categorias opostas. E embora Hegel ainda não tenha conseguido se desfazer do pressuposto de que todo pensamento é simples reflexão, a exigência de apreender e expressar a vida infinita sem destruí-la parece levá-lo para além dos contornos do entendimento, formulando proposições de caráter dialético: "a vida é a ligação da ligação e da não ligação" (das Leben sei die Verbindung der Verbindung und der Nichtverbindung) (SF, HW I, p. 422), isto é, não a simples ligação exigida pelo entendimento da relação e da contraposição, à qual a não-ligação novamente se contraporia, mas a ligação da unidade com a contraposição que lhe é imanente. Isto é, se para a reflexão não há um "ponto de repouso" (Ruhepunkt) em seu "ser-impelidoadiante" (Fortgetriebenwerben) na cadeia infinita de finitudes na qual o entendimento está enredado, a unidade de contrários deve poder ser reconhecida, pela reflexão, como 
estando para além da reflexão: “Aquilo que é denominado ligação da síntese e da antítese não é algo posto [Gesetztes], algo entendido [Verständiges], algo refletido [Reflektiertes], mas antes seu único caráter para a reflexão consiste em que ele é um ser exterior à reflexão" (SF, HW I, p. 422). Como entender isso? Como a reflexão, em seu pensar limitado, pode ter "para ela" aquilo que é exterior a si mesma? Aqui parece residir um achado fundamental que resulta da confrontação da reflexão com a unidade para ela indizível da vida ${ }^{280}$.

É possível um pensar que seja reflexão, mas que não mais seja mera reflexão? Uma forma de pensar que não seja, por definição, um fracasso em atingir a unidade que pretende abarcar? Não seria esse "ser exterior à reflexão" (Sein außer der Reflexion), que a própria reflexão reconhece, o indício de que a reflexão já está parcialmente além de si mesma, reconhecendo uma unidade que lhe transcende, e que, todavia, é para ela uma exigência surgida a partir de suas próprias operações? Note-se que não se trata mais do simples reconhecimento de um domínio que lhe seja exterior, tal como o entendimento e a reflexão já podiam admiti-lo sob a marca do milagre ou do mistério. Agora a reflexão não se depara simplesmente com um além de si, mas o constitui através de suas operações; a reflexão e as contradições que erige participam positivamente na construção de um âmbito que se caracteriza como supra-reflexivo. O sentido preciso dessa diferença torna-se claro se nos ativermos ao novo estatuto da reflexão no interior do movimento de apreensão da vida infinita, do absoluto.

O domínio do pensamento ainda é aqui identificado à mera reflexão, de modo que a filosofia, "que é um pensar e, portanto, tem uma oposição, por um lado, entre ele e o não pensar e, por outro, entre o pensante e o pensado", não pode levar a cabo aquele movimento de elevar o ser humano da vida finita à vida infinita, e portanto, escreve Hegel, "tem de terminar com a religião" (SF, HW I, pp. 422-23). Se o Systemfragment

\footnotetext{
${ }^{280}$ Podemos entrever aqui o motor da dinâmica que caracterizará o movimento fenomenológico da consciência na Fenomenologia. A reflexão é, do ponto de vista da cisão, apenas separação, e absorvida em si mesma não é capaz de ver a unidade daquilo que cinde. O que Hegel irá chamar de especulação é a visão que reconhece a unidade na qual os termos cindidos tem expressão e a partir de onde ganham alguma subsistência. Na Fenomenologia, esta diferença de ponto de vista da reflexão finita e o ponto de vista da especulação é expressa entre a consciência, unidade que apenas vê diante de si um objeto separado, e a perspectiva do "para nós" que reconhece a unidade invisível à consciência individual. Cf. PhG, HW III, pp. 76-77.
} 
ainda toma o pensar como limitado e restrito às deficiências da "má reflexão" ${ }^{281}$, e nesse sentido se encontra em harmonia com o atitude geral de Hegel em Frankfurt, a 'reflexão' (ou será já aqui um esboço enfraquecido da reflexão especulativa?) já reconhece algo além de si no qual ela mesma, todavia, também se insere. É a partir dessa inserção que devemos compreender o sentido da frase: "a filosofia tem de terminar (aufhört) com a religião"; trata-se de um processo que deve passar pela filosofia, pelos impasses da reflexão, e terminar, isto é, chegar à religião. Ou seja, o pensamento reflexivo é reconhecido agora como possuindo uma função no movimento próprio à religião de ascensão ao absoluto. Hegel escreve que "a morte, a contraposição, o entendimento estão simultaneamente postos no todo vivo" e o finito traz dentro de si a possibilidade de se elevar à vida infinita (SF, HW I, p. 422). Surge assim para a filosofia uma tarefa subordinada à religião, que o fragmento de 1800 assim descreve:

"[A filosofia] tem de indicar em todo o finito a finitude e, através da razão, exigir a complementação do mesmo; em especial, tem de reconhecer as enganações causadas pelo seu próprio infinito e, assim, pôr o verdadeiro infinito fora dos limites de seu âmbito" (SF, HW I, p. 423). ${ }^{282}$.

Se podemos, é verdade, reconhecer aqui uma semelhança desta tarefa com aquela que se apresentava à filosofia crítica - afinal a Crítica fazia da indicação das ilusões da metafísica tradicional e da transposição dos seus temas maiores para uma esfera suprateórica o cerne de seu empreendimento -, devemos reconhecer que no caso do Systemfragment a ênfase se volta à aniquilação da finitude, e no reconhecimento de que em si mesma ela não é senão sua própria supressão, isto é, infinitude. E que, portanto, toda espécie de infinitude que for apresentada e permanecer contraposta à finitude, tal como ocorre em uma filosofia que afirma decisivamente a finitude de sua reflexão e a incognoscibilidade do incondicionado, não tem positivamente nada diante de si, "pois

281 "A má reflexão é a subsistência das determinidades da oposição". Hegel, Fragmente aus Vorlesungsmanuskripten (1801/1802), In: G. W. F. Hegel. Gesammelte Werke, Band 5, p. 264.

${ }^{282}$ Ver também a definição que Hegel fornece da função da Lógica nos cursos de 1801/1802. Logica et Metaphysica, In: Fragmente aus Vorlesungsmanuskripten (1801/1802), In: G. W. F. Hegel. Gesammelte Werke, Band 5, p. 264. 
esse infinito não é verdadeiro, porque não é capaz de consumir [aufzehren] completamente a finitude" (GuW, p. 300).

Isto significa dizer que o que é fundamental nesse trecho de 1800, que ainda vacila em relação às potencias da filosofia, é que a tarefa atribuída à filosofia é a de reconhecer a limitação de seu próprio âmbito enquanto reflexão finita, e com isso aperceber-se de que seu infinito (o infinito conceitual formal, aquele que é oposto ao finito, e cuja supressão é uma tarefa infinita), nada mais é do que uma infinitude negativa, resultante da pura contraposição. Se, pois, por um lado temos de afirmar que Hegel ainda toma a filosofia como um pensar reflexivo e, portanto, como entendimento, temos de reconhecer também que, ao mesmo tempo, ele já pressente que a reflexão pode operar numa outra direção e deixar de ser simples reflexão do entendimento. O que está sendo apresentado em 1800 é, portando, o processo inicial de uma superação imanente do pensar finito e das finitudes que ele produz. O sentido positivo dessa outra forma de reflexão, porém, ainda não pode ser apresentado em Frankfurt e o resultado do esforço da reflexão em pensar a vida infinita ainda aponta para um além da reflexão, além do saber, enfim, para a religião. A reabilitação do conhecimento e da reflexão em uma modalidade superior transformará essa oposição em Frankfurt caracterizada entre filosofia e religião em uma nova oposição entre uma má-filosofia (filosofia do mau infinito) e uma verdadeira filosofia, única forma de conhecimento efetivo do infinito ${ }^{283}$.

Temos assim de reconhecer como o passo decisivo da transformação do sentido da reflexão se configura como recusa dos pressupostos críticos que imediatamente identificam o pensar à reflexão do entendimento e que, conseqüentemente, tomam toda forma de conhecimento como sendo finito, isto é, submetido aos contornos de uma subjetividade finita. Se a vida infinita, vida como processo dinâmico, unidade do finito e infinito, é colocada no Systemfragment como estando para além da reflexão, das suas categorias finitas, simultaneamente, no entanto, a cisão característica da reflexão é apreendida como constitutiva da dinâmica própria da vida, de modo que aquela heterogeneidade inicial é relativizada e o modo de proceder da reflexão revela-se momento da própria totalidade viva. Isto significa que as separações do refletir não são mais imediatamente retiradas da esfera objetiva e reconduzidas à unidade abstrata do

${ }^{283}$ Cf. Haering, T. Hegel. Sein Werk und sein Wollen, I, pp.543-544. 
sujeito que a ela permanece contraposta, mas reconhecidas como formas efetivas da vida.

Não se trata, portanto, de recusar integralmente o vocabulário próprio à "linguagem da reflexão" e renunciar definitivamente a uma expressão positiva acerca da vida, mas trata-se, sobretudo, de reconhecer a ambigüidade do pensamento e de, a partir disso, desconstruir a unilateralidade cristalizada nesta semântica única que orienta a interpretação finita do conhecimento. Ao invés de recusar suas palavras, Hegel procura aprofundá-las e reconhecê-las a partir de um outro horizonte semântico, o do conhecer absoluto. 


\section{CAPÍTULO IV}

\section{ESPECULAÇÃO E A AMBIGÜIDADE DO PENSAR}

Em nosso capítulo anterior acompanhamos como o procedimento reflexivo do entendimento caracteriza-se por ser um "pensar finito" que opera com conceitos que não conseguem acessar o modo próprio de ser da vida enquanto uma unidade dinâmica de contrários. Buscamos ali reconstituir a maneira pela qual Hegel caminhava, ao longo dos textos de Frankfurt, em direção a uma superação da heterogeneidade entre as formas de expressão reflexivamente produzidas e o processo da vida que elas pretendem apreender conceitualmente. Essa relação conflituosa entre reflexão e vida constituía o núcleo de suas elaborações no período de Frankfurt, e tendiam a uma sistematização cada vez maior sob a "forma da reflexão" que, como vimos, já estrutura o modo de pensar do Fragmento de Sistema, último escrito do período.

O Systemfragment descrevia o esforço da reflexão em pensar a totalidade viva da vida através de seus próprios conceitos e no interior de uma lógica que parecia de antemão inadequada para esse fim, isto é, que parecia impedir sua conceitualização ao invés de possibilitá-la. O texto desenvolvia assim a idéia de que a vida limitada, vida pensante e finita não pode acessar reflexivamente a vida infinita acima das contraposições estabelecidas pelos seus próprios conceitos. A grande deficiência da reflexão, e do pensar em geral, permanecia ligada, no fragmento de 1800, ao fato de que os diversos momentos e as figurações da vida não podiam ser efetivamente pensados em uma unidade, mas esta apenas postulada abstratamente como um mero pressuposto que a reflexão devia pôr em uma esfera para além de si mesma. Este infinito do pensamento a que a razão podia chegar não era outra coisa do que uma falsa infinitude, pois não resultava de uma verdadeira unificação como elevação da vida finita à vida infinita, mas apenas da postulação de um infinito a partir da negação simples de toda finitude, e 
portanto, uma infinitude negativa que ainda permanecia a ela contraposta ${ }^{284}$. Como vimos, essa "má infinitude" era aquela que Hegel reconhecia ser o ponto mais elevado a que se chegava através da filosofia; um infinito subjetivo resultante da negação do campo objetivo, que acabava por consolidar de maneira definitiva a cisão entre as esferas subjetiva e objetiva.

Todavia, o Fragmento de Sistema não se restringia a repetir essa temática dos limites da reflexão já exaustivamente trabalhada nos demais escritos do período de Frankfurt e o seu resultado verdadeiramente significativo era, sobretudo, o de apresentar uma reconfiguração dos limites da reflexão. Esta se caracterizava pelo ultrapassamento, ainda incipiente, do modo finito de proceder da reflexão, o que permitia o primeiro reconhecimento de um descolamento da razão em relação ao entendimento, instâncias até então não diferenciadas por Hegel. Ao reconhecer a unilateralidade de todo ponto de partida pressuposto pela reflexão, assim como das conclusões a que se pode chegar através dela, a razão já não se encontrava mais inteiramente identificada à reflexão finita, muito embora Hegel ainda não possuísse uma linguagem capaz de exprimir adequadamente esta distância, uma vez que era apenas o entendimento que tinha "direito à palavra" ${ }^{285}$. A conseqüência desta diferença meramente pressentida ${ }^{286}$ era a necessidade de distinguir conceitualmente essas diferentes formas de interpretação do modo de operação da reflexão, destacando da reflexão finita do entendimento uma operação reflexiva capaz de ascender à ordem da verdadeira infinitude, sem fixar seus produtos finitos numa forma de separação definitiva. Essa distinção de modalidades operacionais da reflexão ${ }^{287}$, fundadas em diferentes formas de interpretação da reflexão é o que levará Hegel a estabelecer definitivamente a separação entre Razão e

\footnotetext{
284 “O infinito, na medida em que é contraposto ao finito, é um racional posto pelo entendimento [ein vom Verstand gesetztes Vernünftiges]; exprime para si como racional apenas a negação do finito. Na medida em que o entendimento fixa o infinito, ele o contrapõe absolutamente ao finito...". Hegel, DS, p. 21.

${ }^{285}$ Lebrun, G. A Paciência do Conceito, p. 310.

${ }^{286}$ Sobre a idéia de um "pressentimento da razão" Ver Carta a Windischmann (25.05.1810), Briefe von und na Hegel, Band. II p. 314. Ver também Carmo Ferreira, M J. Hegel e a justificação da filosofia, p.87.

${ }^{287}$ Cf. Baum, M. Die Entstehung der hegelschen Dialektik, p. 93.
} 
Entendimento, não como duas faculdades do espírito com funções diversas, mas sobretudo como duas formas distintas de apreensão do real ${ }^{288}$.

Se até 1800 a totalidade da vida permanece incognoscível pelas categorias da reflexão, e o princípio de contradição um limite inultrapassável para o pensar em geral, a reinterpretação racional da reflexão será, antes de tudo, uma reabilitação da idéia de conhecimento (Erkenntnis) em uma modalidade superior do pensamento, e que será chamada, a partir dos escritos de Jena, de especulação (Spekulation). O esforço de Hegel será, portanto, a partir da obra que inaugura esse período, o Differenzschrift, o de reconhecer a ambigüidade própria do pensar, o qual pode ser considerado tanto como um modo de reflexão abstrata, conduzida pelo entendimento, assim como uma "atividade absoluta da razão", cuja modalidade de conhecimento será concretizada enquanto filosofia.

"Assim como a razão se transforma em algo de entendimento [ein Verständiges] e sua infinitude em infinitude subjetiva, quando é posta em uma contraposição, assim também a forma que o refletir como pensar assume se presta precisamente a esta ambigüidade e a este abuso. Se o pensar não for posto como a atividade absoluta da própria razão, para a qual não há simplesmente nenhuma contraposição, mas for considerado apenas um refletir mais puro, quer dizer, um refletir no qual apenas se abstrai da contraposição, então tal pensamento abstrativo não pode nem sequer sair do entendimento em direção à lógica, que deve incluir em si a razão, e muito menos em direção à filosofia" (DS, p. 28).

Compreender essa ambigüidade implica, por conseguinte, explicitar o conceito de reflexão reinterpretado especulativamente na sua nova função positiva de instrumento no conhecimento da unidade viva, que será a partir de agora, em influência direta de Schelling, chamada de o Absoluto (Das Absolute) ${ }^{289}$. Essa denominação não é, no entanto, o simples resultado de um empréstimo tomado da filosofia de Schelling, mas está intimamente vinculada ao novo estatuto da reflexão e da filosofia na tarefa de

${ }^{288}$ Cf. Marcuse, H. Razão e Revolução, pp. 49-54.

${ }^{289}$ Cf. Schelling, Darstellung meines Systems der Philosophie. "Não há nenhuma filosofia, senão aquela do ponto de vista do absoluto; sobre isso não se coloca dúvida alguma nessa apresentação inteira: a razão é o absoluto, na medida em que ela é pensada, tal como a determinamos." SW, (IV 115), p. 11. 
apreensão dessa estrutura dinâmica da vida. Devemos, pois, ao longo desse capítulo, compreender como a perspectiva especulativa possibilita essa transformação da reflexão e, dessa forma, a superação dos seus impasses na direção da construção de um saber efetivo (Wissen) do absoluto.

\section{A reinterpretação especulativa da reflexão}

A ambigüidade do pensamento que se concentra na noção de reflexão não é outra do que aquela que Hegel encontra nas "filosofias da reflexão" e, principalmente, na filosofia de Kant. Ou seja, quando Hegel censura a filosofia kantiana de se manter apenas um "pensamento do entendimento", ele está apontando, sobretudo, qual $o$ posicionamento de Kant frente à ambigüidade de seu próprio pensamento, explicitando assim a opção interpretativa da reflexão que a filosofia crítica assume na base de seu empreendimento. A libertação da reflexão de uma "interpretação falseadora" ${ }^{290}$ - devido sua unilateralidade -, é o que abre o horizonte para uma perspectiva que não parta do princípio de que o pensar está limitado à finitude. O questionamento desse parti pris posto em marcha pela filosofia crítica é o que propicia o nascimento da filosofia especulativa.

O conceito de Spekulation em Hegel será, portanto, fundamentalmente distinto daquele apresentado por Kant, pois tanto a reflexão filosófica quanto a noção de conhecimento serão reinterpretados a partir de uma perspectiva totalmente diversa daquela assumida pela filosofia crítica. Ao contrário de um modo de conhecer ilegítimo que deve ser restringido por uma reflexão finita que põe a finitude como limite do pensar, a especulação será compreendida por Hegel como uma forma legitima e efetiva de conhecimento. Nesse sentido a tarefa da filosofia especulativa será a de elevar o entendimento para além de si mesmo, isto é, subvertendo a sua interpretação unilateral da reflexão, reconhecendo a razão como sua verdade. Conhecer não será mais uma atividade da razão tomada ao nível do entendimento que aprisiona seus resultados na finitude. Pelo contrário, conhecer é agora uma atividade racional e seu objeto a própria razão considerada de forma absoluta. Reinterpretação especulativa da reflexão quer dizer,

${ }^{290}$ Cf. Lebrun, G. A Paciência do Conceito, p. 314. 
portanto, a liberação da reflexão da figura limitada em que se encontra como reflexão do entendimento, para elevá-la à reflexão como razão. Isso não significa, no entanto, que Hegel procure encontrar um dizer para além da reflexão, como buscava em Frankfurt, mas sim um dizer para além da interpretação tradicional da reflexão. Devemos portanto agora reconhecer como se dá essa transformação de sentido da reflexão que caracteriza o nascimento da especulação hegeliana.

Vimos como desde o Fragmento de Sistema Hegel opera decididamente sob a "forma da reflexão", buscando sistematizar reflexivamente a relação entre finito e infinito que constituía o tema central de seus estudos anteriores acerca da religião ideal. Se nesse último fragmento de Frankfurt a reflexão se deparava com a impossibilidade de expressar uma dinâmica que a todo o momento lhe escapa, ela passava, porém, a ter um papel importante na indicação dos limites das suas próprias categorias, revelando assim a finitude de seu procedimento, e encaminhando a superação da finitude para a sua realização numa esfera religiosa. É por essa razão que ali Hegel escrevia que a filosofia deveria "terminar com a religião", e isso no sentido de que nesta última residia a única forma possível de realização da passagem das limitações da vida finita, reconhecidas pela razão, à vida infinita, na medida em que podia oferecer uma contemplação dessa totalidade infinita, uma intuição (Anschauung) da dinâmica da vida na figura do divino $^{291}$.

Essa intuição oferecida pela religião permanecia, no entanto, essencialmente ligada a uma ausência de consciência (Bewußtlosigkeit) própria ao sentimento religioso, uma vez que a elevação à vida infinita era considerada por princípio como não reflexiva e, portanto, não realizável e apresentável no âmbito finito da consciência. Se o sentimento religioso, que Hegel apresentara como nutrindo sua força a partir dos próprios impasses do refletir, podia realizar a elevação da vida finita à vida infinita, ele não era capaz, contudo, de conhecer essa mesma unidade do finito e infinito. A fé permanece, pois, como uma intuição do divino numa espécie de interioridade inexprimivel, que abandona a esfera da contraposição experimentada na consciência e se eleva a uma identidade que abstrai das limitações produzidas pela reflexão ${ }^{292}$. A partir de Jena, a transformação do

${ }^{291}$ Cf. Hegel, GCh, HW I, p. 386.

${ }^{292}$ Cf. Hegel, DS, p. 32. 
sentido da reflexão levará Hegel a uma também nova compreensão do modo de ser do sentimento de fé, que não mais será um contraposto à reflexão, como em Frankfurt, mas ao contrário uma "forma incompleta da reflexão" ${ }^{293}$, isto é, como um modo invertido de relação da reflexão ao absoluto em que ainda se "conserva, portanto, a forma da separação [Form der Trennung]" (DS, p. 32). Conservando-se a separação, aquilo que se pretendia apreensão o absoluto revela-se antes como a sua supressão, pois a infinitude que se mantém contraposta à finitude não pode ser absoluta. Eis a razão pela qual os textos de Jena são críticos à idéia da "certeza imediata da crença" em voga na época, e encontram como seu alvo privilegiado a relação insatisfatória que a fé mantém com o absoluto. Esta também é a razão pela qual uma filosofia como a de Jacobi pôde ser tomada por Hegel no conjunto das "filosofias da reflexão".

Se, portanto, "a fé não exprime o caráter sintético do sentimento ou da intuição" (DS, p. 32), como Hegel escreve em 1801 revendo a sua posição dos tempos de Frankfurt, é necessário, então, encontrar uma forma efetiva de conhecimento que seja capaz de apreender a verdadeira infinitude, um absoluto que não seja aquele postulado pelo sujeito finito. Este será, pois, o esforço de Hegel presente nos primeiros textos de Jena: apresentar a superação da finitude que não caminhe no sentido de um não-saber, isto é, sem abandonar inteiramente o solo reflexão como se dava no caso da intuição religiosa. Trata-se, pois, da tarefa de chegar a um saber (Wissen) acerca do absoluto, chegar à "identidade consciente do finito e da infinitude" ${ }^{294}$, que não pode ser reconhecida pelo pensar do entendimento. A exigência de elevar a identidade de contrários à consciência (Bewußtsein), não é outra coisa senão um desenvolvimento daquela necessidade de sistematização e do "impulso à ciência" (Wissenschaft) pressentidos em Frankfurt que já se apresentavam de maneira ainda vaga através da idéia geral de uma "consideração metafísica da relação entre finito e infinito" ${ }^{295}$.

O projeto que inaugura a filosofia especulativa de Hegel diz respeito então a uma reconfiguração geral dos limites do saber, e isso a partir de um reposicionamento em relação à filosofia e a toda forma de pensar. Aquilo que irá garantir que esse saber não se transforme novamente em uma simples exigência abstrata da razão, como Hegel

\footnotetext{
${ }^{293}$ Cf. Baum, M, Die Enstehung der hegelschen Dialektik, p. 96.

${ }^{294}$ Hegel, DS, pp. 27-28. O grifo é de nossa autoria.

${ }^{295}$ Cf. Düsing, K, op cit, p. 73; e também, Haering, T, op cit, pp. 601-611.
} 
denunciava ocorrer no âmbito da filosofia - entendida então como reflexão finita -, tem de ser sua relação com o modo de ser da vida, orientação que Hegel mantém desde Frankfurt. É isso que a advertência previa do Differenzschrift pretende indicar através da idéia da "necessidade da filosofia", buscando reconhecê-la na sua correspondência à vida que ela pretende poder expressar.

Em Frankfurt, Hegel empregava com freqüência o termo "necessidade" (Bedürfnis) quando se referia à unificação do finito e do infinito em um divino, afirmando ser esta uma "necessidade suprema do espírito humano" que constitui o “impulso" para a religião, única esfera da vida dos homens capaz desta elevação (Erhebung) à infinitude. A filosofia, por sua vez, não podia deixar de se exprimir na "linguagem da reflexão", e a sua maior contribuição não ultrapassava a de uma tarefa subordinada de preparação para o terreno religioso. Porém - e aqui podemos reconhecer um passo decisivo na constituição da filosofia de Hegel a partir de Jena - se a filosofia não podia realizar a unificação almejada, seu impasse reproduzia no âmbito da consciência as mesmas cisões e separações experimentadas no plano da vida. Com isso, a consciência passava a ser reconhecida como espaço privilegiado de experiência e de tematização das cisões da vida e suas cristalizações próprias à sua situação histórica determinada e à cultura da época. Hegel reconhece assim nos sistemas filosóficos uma atividade do espírito na busca de restituir à vida a unidade dinâmica que o progresso da cultura enrijeceu, e cuja cristalização se estabeleceu de maneira definitiva em todas as esferas da vida. Esse "dilaceramento" (Zerrissenheit) que caracteriza o modo de vida moderno - e Hegel tem em vista em especial a condição política da Alemanha ${ }^{296}$-, é reconhecido, portanto, na sua correspondência à separação (Trennung) interna ao próprio pensar característica do domínio absoluto do entendimento, cuja intensidade é tanto maior quanto maior for a rigidez com que a cisão (Entzweiung) é fixada. "Quando o poder de unificação desapareceu da vida dos homens, e as oposições perderam sua relação viva e a sua ação recíproca [Wechselwirkung] e ganharam autonomia, surge a necessidade da filosofia [Bedürfnis der Philosophie]” (DS, p. 22).

A cisão é, portanto, a "fonte da necessidade da filosofia", conforme lemos na famosa sentença do Differenzschrift, e sua tarefa é agora determinada a partir dessa

${ }^{296}$ Cf. Hegel, Die Verfassung Deutschlands, (HW I, 461-581). 
origem e em função dela. A época moderna perdeu a capacidade de reconhecer a vida enquanto relação viva, e as diversas manifestações da cultura (Bildung), a arte, a religião, a política não mais encontram um vínculo que as unifique como expressão de uma mesma totalidade. A conseqüência desta autonomização e separação das diversas esferas da cultura é a perda da compreensibilidade de cada uma delas pela própria cultura que a produziu. Hegel expressa isso da seguinte maneira: "na cultura, aquilo que é manifestação do absoluto [Erscheinung des Absoluten] isolou-se do absoluto e fixou-se como algo autônomo" (DS, p. 20). Expresso de tal forma, reconhecendo a cultura como uma manifestação do absoluto, Hegel já aponta para a unidade cindida que deve ser reconstruída pela filosofia: "A manifestação não pode negar a sua origem e deve partir daí para constituir como um todo a multiplicidade de suas limitações" (DS, p. 20), eis a tarefa da filosofia e sua correspondência direta com a dinâmica da vida da qual ela surge 297.

Como vimos, já ao final do período de Frankfurt Hegel não considera mais as cisões e separações características do pensamento reflexivo como instâncias absolutamente heterogêneas ao modo da vida se processar; ao contrário, elas passaram a ser reconhecidas como momentos interiores e constitutivos da própria dinâmica da vida. Nesse sentido, a necessidade da filosofia e o interesse da razão na apreensão da totalidade viva não pode significar, a partir de então, que a razão,

"se coloque em geral contra as oposições e as limitações; pois a cisão necessária é um fator da vida, que se forma a si mesma opondo-se eternamente, e a totalidade só é possível, na forma suprema da vida, através do restabelecimento a partir da suprema separação" (DS, pp. 21-22).

Esse reconhecimento da contraposição como fator da vida (Faktor des Leben) justifica ao pensar a tarefa de restabelecer a unidade da vida na medida em que ela perdeu seu movimento vivo, sua Lebendigkeit, e se encontra fixada de maneira abstrata em uma época que é dominada pela "cultura do entendimento", e pelo modo de pensar analítico. A atividade da filosofia, portanto, deixa de ser pensada como mera aniquilação da

297 “Compreender essa relação viva originária é a necessidade da filosofia, e isto significa reconhecer novamente o absoluto na totalidade objetiva; esta não deve ser mais tomada como mera manifestação para si mesma subsistente, mas como manifestação do absoluto, ou posta a partir de sua absolutidade ”. Dottori, op cit, pp. 138-139. 
separação em uma unidade pura e indiferente em relação aos seus momentos constitutivos - tal como Hegel caracterizava a figura do conceito em Frankfurt -, mas responde ao interesse da razão em combater "a fixação absoluta da cisão por meio do entendimento" (DS, p. 22).

Dessa forma, a decisão em operar no âmbito da reflexão (necessidade da filosofia) não é uma questão de mera adequação ou escolha, mas antes o fruto de uma "necessidade do tempo" (Zeitbedürfnis), oriunda de uma situação histórica e filosófica determinada, marcada pela cristalização e rigidez da dinâmica própria da vida. No entanto, entre o reconhecimento da separação como "fator da vida" e o reconhecimento da reflexão como operação positiva no conhecimento da unidade absoluta, há uma distância cujo percurso ainda não está esclarecido. Se a filosofia tem sua necessidade surgida da vida, resta saber como a reflexão com suas leis próprias responde a essa necessidade. A determinação da tarefa da filosofia a partir de sua necessidade é o horizonte do Differenzschrift de 1801.

Hegel apresenta isso afirmando que quando a reflexão se volta à necessidade da filosofia, ela arquiteta sua tarefa no interior de sua lógica própria, estabelecendo para a filosofia dois pressupostos: o primeiro é o próprio absoluto, que para ela já está presente negativamente: “de outro modo, como poderia ser procurado?". O segundo pressuposto que ela tem para si é a cisão, "a saída da consciência da totalidade", separação entre finitude e infinitude. Ocorre que para a própria reflexão, enquanto operação do entendimento, esses pressupostos permanecem contrapostos e não há uma síntese possível que seja alcançável: "para o ponto de vista da cisão, a síntese absoluta é um além” (DS, p. 24). Se o pensar for, assim, imediatamente identificado à reflexão do entendimento, "o ponto de vista da cisão" é tornado o absoluto do pensamento e a tarefa da filosofia estará de antemão fracassada. Mas a tarefa da filosofia não é permanecer na contradição instaurada pelo seu próprio modo de ação; "a tarefa da filosofia consiste em unir estes pressupostos, em pôr o ser no não-ser - como devir, a cisão no absoluto - como sua manifestação, o finito no infinito - como vida" (DS, p. 25).

Em outras palavras, para realizar a sua tarefa a filosofia não pode permanecer reflexão do entendimento e seu objeto não pode ser a vida fixada, expressa em contrapostos não unificáveis, ou um infinito que permanece contraposto ao finito. Sem o aprofundamento da reflexão e o reconhecimento do princípio racional que a conduz - 
ponto de vista da unidade -, o absoluto permanecerá para a reflexão sempre um além. $A$ necessidade da filosofia é, portanto, uma necessidade especulativa da razão, e seu sucesso não poderá surgir a partir de uma simples contraposição ao entendimento, mas de um aprofundamento do real sentido de seu modo de pensar. Sem o reconhecimento de que o pensar carrega em si esta ambigüidade, a razão pressentida permaneceria indefinidamente rebaixada ao nível do entendimento.

Muito ilustrativa é, nesse sentido, a seguinte advertência prévia que Hegel faz ao escrito de 1801, visando determinar a ambigüidade necessária assumida pelo seu próprio projeto, e a partir da qual podemos ver como a filosofia já não é mais identificada ao procedimento abstrato de uma simples reflexão:

"No que diz respeito às reflexões gerais, com que este escrito começa, sobre necessidade, o pressuposto, os princípios, etc., da filosofia, têm o defeito de ser reflexões gerais, e têm a sua razão de ser no fato de com tais formas como o pressuposto, princípios, etc., o acesso à filosofia ser continuamente adiado e ocultado e, por isso, é, de certo modo, necessário deixar-se introduzir nela, até ao ponto de ser inteiramente e unicamente da filosofia que se trata". (DS, pp. 13-14).

Podemos reconhecer nessa passagem a grande distância que Hegel já mantém em relação à sua posição nos textos de Frankfurt. Se Hegel aborda como de costume as deficiências das "reflexões gerais", cujo caráter abstrato toma conta da maioria dos sistemas filosóficos de sua época, vemos de maneira clara como sua postura já não é mais a de uma recusa da reflexão em si mesma como forma inteiramente inapropriada para pensar a vida; ao contrário, seu escrito apresentará a tarefa da filosofia através da lógica própria da reflexão, fazendo uso das mesmas categorias. Hegel pretende mostrar com isso que não é a reflexividade em si mesma que impede o saber da vida, mas sim a interpretação tradicional que dela se faz, que a considera de antemão como um pensar abstrato de um sujeito finito que adia indefinidamente o acesso à verdadeira filosofia, se não o impede por completo. O Differenzschrift pretende, dessa forma, apresentar uma reconfiguração da reflexão a partir de dentro, isto é, a partir da própria operação reflexiva, com a cautela apenas de não a tomar de antemão como sendo ela mesma, necessariamente, signo definitivo da finitude. 
Se Hegel não mais identifica toda espécie de "reflexão filosófica" (philosophische Reflexion) à reflexão do entendimento, devemos então buscar esclarecer qual é esse seu novo sentido e em que medida ele representa uma ampliação em relação aos limites restritos do pensamento finito. Digno de nota é como a expressão "reflexão filosófica" é constituída pelos mesmos termos que a expressão "filosofias da reflexão" que, como vimos, Hegel empregará em 1802 para censurar a filosofia de Kant, Fichte e Jacobi, e cuja tensão já se indicou. O mesmo ocorre, como pretendemos apresentar, com a expressão "reflexão filosófica", de modo que podemos agora com segurança afirmar que tal tensão reside precisamente na indeterminação do modo com que a reflexão é aí interpretada.

Por "reflexão filosófica" Hegel entende, em um primeiro sentido geral, toda forma de pensar que toma a própria razão como objeto de sua reflexão. Nesse sentido, todo pensamento que compartilha da perspectiva aberta pela filosofia crítica de Kant ${ }^{298}$, cuja atitude principal é a de tornar a razão o objeto de sua própria investigação, merece o título geral de "reflexão filosófica". E Hegel tem aqui a reflexão kantiana em vista, não sendo mera coincidência que ele próprio defina a filosofia através de uma expressão quase idêntica àquela que Kant oferece sobre a Lógica, afirmando que na filosofia "a razão que se conhece a si mesma e tem a ver somente consigo" ${ }^{299}$. Reflexão filosófica significa então, num primeiro sentido, o auto-conhecimento da razão. Entretanto, como o termo reflexão permanece ainda indeterminado em relação ao sentido de sua operação, igualmente indeterminadas se mantêm aqui as noções de conhecimento e de razão.

O Differenzschrift pretende então apresentar uma interpretação da reflexão que não compartilhe dos pressupostos críticos que fazem da reflexão uma atividade eminentemente negativa, e cuja participação positiva no conhecimento esteja restrita à sua consideração como uma instância meramente subjetiva e conseqüentemente finita. A reinterpretação da reflexão para além dos contornos que ela recebeu na filosofia crítica significa tomar a expressão "auto-conhecimento da razão" em seu sentido mais forte, isto é, como um conhecimento real e efetivo da razão, não relativizado pelas formas da subjetividade, ou seja, como um conhecimento absoluto da razão. Esse conhecimento

\footnotetext{
${ }^{298}$ Cf. Dottori, R, Die Reflexion des Wirklichen, p. 127

${ }^{299}$ Hegel, DS, p. 17. A expressão de Kant é: "Na lógica, o entendimento não se ocupa com nada mais do que consigo mesmo e com suas formas". Kant, KrV, B IX.
} 
absoluto da razão pela razão não pode ser então um simples retorno às faculdades do conhecimento, pelo qual se caracterizava a postura kantiana, mas deve assumir o sentido de uma elevação (Erhebung) da razão para além das finitudes da consciência às quais o princípio de subjetividade necessariamente reconduz. Isto não quer dizer, como se compreenderia no interior dos contornos da filosofia crítica, que a razão deve agora conhecer a "coisa em si" que se contrapõe à subjetividade do conhecimento; isso seria permanecer na contraposição instaurada pela interpretação finita do conhecimento. Conhecimento absoluto da razão é reconhecê-los, razão e conhecimento, como absolutos, de forma que da finitude da consciência a razão se eleve somente a si mesma, enquanto absoluta. "Pois a razão (...) só se tornará especulação filosófica na medida em que se elevar a si mesma e se confiar a si mesma e ao absoluto, que se tornará ao mesmo tempo seu objeto.” (DS, p. 19). Como essa interpretação do conhecimento e da razão subvertem o sentido que ambos recebem no sistema kantiano, Hegel deve destacar a interpretação absoluta da tarefa da filosofia da determinação que a "reflexão filosófica" recebe na obra de Kant.

Hegel afirma que o sistema kantiano é dominado por uma "reflexão raciocinante" (räsonierenden Reflexion) que se sobrepõe sobre o princípio especulativo que ali se apresenta, fazendo assim com que o Reflektieren, ponto máximo a que chega sua filosofia, tome o lugar do Philosophieren. A reflexão que se apossa da verdadeira filosofia é por isso um "raciocinar negativo" (negatives Räsonieren) que não é capaz de chegar a um conhecimento positivo do absoluto, mas seu agir é apenas orientado pelo entendimento no sentido de limitar as pretensões do conhecimento especulativo. Trata-se da reflexão conduzida pelo entendimento, cujas categorias não podem alcançar a esfera do incondicionado e estabelecem, assim, o limite do conhecimento no interior dos contornos da subjetividade finita. Esta reflexão crítica, eminentemente negativa, que opera no sistema kantiano, está assim impossibilitada de reconhecer a razão como absoluta, pois a rebaixa ao pensar do entendimento, e desta forma não consegue sustentar o seu princípio filosófico. Quando o entendimento toma a frente na determinação da tarefa da filosofia, a "reflexão filosófica" não pode ultrapassar a condição de uma investigação das faculdades do conhecimento, da subjetividade finita. 
"Na medida em que a filosofia kantiana explica esse conhecimento finito como o único possível (...), ela recai na finitude e subjetividade absolutas; toda a tarefa e conteúdo dessa filosofia não é o conhecimento do absoluto, mas o reconhecimento dessa subjetividade ou uma crítica das faculdades do conhecimento" (GuW, p. 303).

Todavia se a "reflexão filosófica" não se identificar com a reflexão crítica, nem surgir nutrida dos mesmo pressupostos daquela, e a tarefa da filosofia receber sua determinação exclusivamente a partir do interesse da razão, ela poderá se elevar à “especulação filosófica", reconhecendo a razão como em si mesma absoluta e determinando sua única tarefa, enquanto filosofia, como o conhecimento do absoluto. Pois "quando a razão se conhece a si mesma como absoluta, então aí começa a filosofia, com o que termina aquele modo de proceder que parte da reflexão" (DS, p. 45). Enquanto conhecimento efetivo da razão como absoluta, a especulação será, pois, uma elevação da razão a si mesma, descolando-se de sua interpretação que a identifica ao entendimento. A reinterpretação especulativa da reflexão significa, por conseguinte, a apreensão da reflexão filosófica não mais a partir dos pressupostos críticos, para não circunscrevê-la de antemão à negatividade de sua operação. O que irá determinar agora o alcance da reflexão filosófica terá de ser a própria tarefa da filosofia, o conhecimento do absoluto.

Em outras palavras, a compreensão do sentido da reflexão depende de como a razão responde à pergunta enunciada pelo Differenzschrift: "em que medida a reflexão é capaz de apreender o absoluto?” (DS, p. 25). Apenas a partir de como se responde a essa pergunta é que se pode saber se a reflexão é racionalmente compreendida ou opera a partir da perspectiva do entendimento. Aqui encontramos a raiz da distinção hegeliana entre entendimento e razão, uma novidade em relação aos textos de Frankfurt nos quais ambos os termos eram diretamente identificados. Entendimento e razão não são mais compreendidos como faculdades distintas do espírito ou faculdades supremas do conhecimento que participam em conjunto na constituição da experiência, como a filosofia kantiana os apresentara, mas representam sobretudo "dois modos de procedimento da reflexão" ${ }^{300}$, duas maneiras distintas de interpretar o sentido de sua operação.

${ }^{300}$ Baum, M. Die Entstehung der hegelschen Dialektik, p. 93. 
Pois bem, é preciso que agora esclareçamos em primeiro lugar como a reflexão racionalmente compreendida responde à questão da apreensão do absoluto, para assim diferenciá-la da reflexão tal qual o entendimento a interpreta; e em segundo lugar devemos perguntar pela passagem de uma interpretação a outra, isto é, perguntar como do interior da operação da reflexão crítica a reinterpretação racional pode elevá-la à especulação filosófica, tornando-a assim absoluta. Essa segunda pergunta representa o próprio fio condutor da leitura que Hegel faz da reflexão filosófica de Kant, buscado reconhecer a filosofia que a interpretação finita da reflexão não permite sustentar.

\subsection{Reflexão como instrumento do filosofar: a construção do absoluto para a consciência.}

Qual é, pois, a interpretação especulativa da reflexão? Ou, em outras palavras, quando a reflexão pode ter um sentido positivo no conhecimento do absoluto? Em que medida a reflexão é filosofia e não um mero raciocinar negativo que não é capaz de realizar a tarefa da filosofia? Hegel responde a essas perguntas afirmando que isso ocorre quando ela puder se reconhecer como um "instrumento do filosofar" isto é, quando a reflexão for, ela mesma, reconhecida como razão (als Vernunft). Considerar a reflexão como um instrumento do filosofar é pensá-la agora a partir da tarefa da filosofia, enquanto instrumento para o conhecer do absoluto.

Para a "forma da reflexão" a tarefa de conhecer o absoluto é estruturada enquanto sua construção na consciência e para a consciência. "O absoluto deve ser construído para a consciência, tal é a tarefa da filosofia" (DS, p. 25). Todavia, esta tarefa é para a própria reflexão uma contradição (Widerspruch), "dado que tanto o produzir como os produtos da reflexão são apenas limitações" e o absoluto é um incondicionado que não pode se encontrar na cadeia de condições finitas sem deixar, com isso, de ser absoluto. Esta contradição pode ser expressa da seguinte maneira: "O absoluto deve ser refletido, posto; mas deste modo ele não é posto, mas sim suprimido, pois ao ser posto, tornou-se limitado. A mediação desta contradição é a reflexão filosófica" (DS, p. 25). As determinações finitas e limitadas da reflexão permanecem contrapostas uma à outra, de forma que toda posição (Setzung) na consciência realizada pela reflexão é acompanhada 
de uma contraposição (Entgegensetzung). No momento em que a reflexão põe o absoluto na consciência ela simultaneamente o suprime, pois ao absoluto nada pode haver que the seja contraposto. A "reflexão filosófica" é a partir disso determinada como a mediação desta contradição (Vermittlung dieses Widerspruchs), uma tarefa que leva necessariamente a reflexão ao seu próprio limite.

A "construção do absoluto para a consciência" é, portanto, uma exigência da reflexão e, simultaneamente, uma impossibilidade da reflexão finita, para a qual somente é possível apreender o absoluto suprimido. "Como ter êxito em pôr o absoluto, se a posição é inseparável de uma oposição, a determinação de outra determinação que a condiciona?" ${ }^{301}$. Tal mediação não será possível a menos que se reconheça um pensar que não compartilhe do sentido tradicional da contradição, isto é, que não tome as determinações finitas que a engendram como estáveis e absolutas, tal como as concebe o entendimento que as produziu. Sem questionar a própria contradição como um limite para o pensamento, assim como a tese que dela se nutre, segundo a qual a "reflexão é irremediavelmente exterior ao absoluto", não é possível realizar a tarefa da filosofia, e elevar a reflexão finita à especulação. "É a adesão às mesmas regras de sentido [preconceito da finitude e sua interpretação da contradição] que torna a construção do Absoluto tão pouco realizável aqui...” ${ }^{302}$. Assim sendo, a possibilidade do conhecimento do absoluto depende da correta compreensão do procedimento de construção (Konstruktion) levado a cabo pela filosofia. Dela depende também a transformação efetiva de sentido da reflexão, o reconhecimento da positividade de seu agir, enfim, a compreensão do sentido do conhecer absoluto que Hegel chama de especulação.

Construção é um termo com importância central na filosofia kantiana, particularmente por ajudar a clarificar os limites do modo de conhecer próprio da filosofia. Este termo será um dos alvos da reinterpretação feita pela leitura de Hegel, que tem como horizonte o conhecimento do absoluto, algo que necessariamente o desloca para além dos contornos do pensamento kantiano. Kant apresenta a construção como o modo de apresentação a priori dos conceitos puros da matemática na intuição ${ }^{303}$. Para

\footnotetext{
${ }^{301}$ Lebrun, G, A Paciência do Conceito, p. 315.

${ }^{302}$ Lebrun, G, A Paciência do Conceito, p. 317.

303 "Construir um conceito significa apresentar a priori a intuição que lhe corresponde". Kant, $\mathrm{KrV}$ B741.
} 
Kant o conhecimento filosófico é de natureza distinta do conhecimento matemático, não essencialmente por abordar objetos diversos, mas sobretudo por não poder considerar seus conceitos in concreto, tomando o particular sempre em geral, de maneira exatamente inversa do procedimento matemático. Sendo um conhecimento racional por conceitos, a filosofia não opera segundo um "uso intuitivo da razão" em que há construção de conceitos, mas permanece restrita a um "uso discursivo da razão" 304 . Para Kant, portanto, a filosofia é uma operação reflexiva (discursiva) e que não pode proceder com construção de conceitos.

Antes de Hegel, Schelling já pretende reabilitar o conceito de construção para o conhecimento do absoluto, buscando legitimar para a filosofia um saber não meramente discursivo, algo desautorizado pela filosofia crítica. Em sua leitura de Kant, ele afirmava que o filósofo de Königsberg fora "o primeiro a apreender o conceito de construção de modo tão profundo e autenticamente filosófico", e isso porque através dele exprimia a “equiparação [Gleichsetzung] do conceito e da intuição" 305, a unidade de ambos enquanto conhecimento. O que Schelling pretende indicar com isso não é que Kant apenas apresentou tal conceito de maneira formal, como uma operação que não participava efetivamente de sua filosofia e deveria permanecer como um simples limite de seu filosofar. Segundo ele, o procedimento de construção na intuição está "envolvido" nos conceitos nucleares da filosofia crítica, tais como o de imaginação transcendental e o de síntese pura da apercepção, muito embora Kant tenha negado sua possibilidade. Schelling afirma, então, que Kant, "constrói sem o saber" e que "se ele tivesse uma consciência completa de sua filosofia" ${ }^{306}$, reconheceria nela a construção de conceitos. Nesse sentido, em movimento análogo ao que veremos em Hegel, Schelling pretende recuperar para a filosofia a idéia de construção.

Mas apesar da proximidade com Schelling, Hegel entende a noção de construção de maneira muito distinta daquele, de forma que se ambos exprimem igualmente a tarefa da filosofia enquanto conhecimento do absoluto, conhecer é tomado em sentido muito diverso em ambos os casos. Esta diferença já se apresenta na pergunta que orienta o escrito de Hegel, pois perguntar "em que medida a reflexão é capaz de apreender o

\footnotetext{
${ }^{304}$ Kant, $\mathrm{KrV}, \mathrm{B} 747$.

${ }^{305}$ Schelling, Über die Konstruktion der Philosophie, SW III, pp.547-548.

${ }^{306}$ Idem, p. 560.
} 
absoluto" é já reconhecer que este conhecimento depende fundamentalmente do trabalho da reflexão e não pode ser o resultado de um saber intuitivo que se sobreponha à discursividade, ou que permaneça a ela contraposta, tal como ocorre com a intuição intelectual pensada por Schelling ${ }^{307}$. Portanto, é importante que reconheçamos o modo especifico com que Hegel transcreve o conceito kantiano de construção a partir da perspectiva da especulação, a fim de explicitar a transformação da reflexão aí em jogo, tendo em vista que aqui se trata, fundamentalmente, da questão do método da filosofia 308

Quando Hegel apresenta a tarefa de construção do absoluto para a consciência ele não pretende aproximar o modo de proceder da filosofia àquele próprio à matemática ou mesmo transformá-la em um ideal a ser perseguido pela filosofia, no sentido de eliminar a heterogeneidade metodológica tão ressaltada por Kant na Disciplina da Razão Pura ${ }^{309}$. Ao contrário, radicalizando ainda mais a diferença do modo de conhecer, Hegel busca reconhecer que tipo de construção seria a propriamente filosófica, de forma a afirmar a possibilidade de um conhecimento concreto do absoluto, isto é, um conhecimento que não seja abstrato ou negativo, como ocorre com as idéias transcendentais na filosofia teórica kantiana.

Como abordaremos em seguida, a idéia do conhecimento enquanto "construção" implica necessariamente a presença de uma intuição, uma apresentação na consciência. E podemos reconhecer nisso a herança daquela contemplação (Anschauung) exigida nos textos de Frankfurt, que Hegel encontrava realizada no sentimento religioso. A isso M. Baum chamou de "relativo intuicionismo" do período inicial de Jena, e que será abandonado em poucos anos, tornando-se, ele mesmo, alvo de crítica na Fenomenologia do Espirito ${ }^{310}$. Contudo, o real papel da intuição presente no conhecimento especulativo somente pode ser compreendido à luz da transformação de sentido a que passa a reflexão. Devemos, pois, antes de tratarmos da participação da intuição no conhecimento do absoluto, voltarmo-nos à contradição experimentada pela reflexão ao buscar construir o

\footnotetext{
${ }^{307}$ Cf. Fujita, M. Philosophe und Religion beim jungen Hegel, p. 144.

${ }^{308}$ Cf. Baum, M. Die entstehung der hegelschen Dialektik, pp. 116-126.

${ }^{309}$ Cf. Kant, KrV, B741-767.

${ }^{310}$ Cf. Baum, M, op cit, p. 124. Ver: Hegel, PhG, HW III, p. 15.
} 
absoluto para a consciência, para que possamos especificar o novo sentido de refletir que surge no interior desta tarefa.

"O absoluto deve ser construído para a consciência" significa para a reflexão uma contradição. $\mathrm{O}$ absoluto deve ser refletido, posto na consciência de um sujeito finito, para o qual ele aparece, inicialmente, como um objeto, isto é, como condicionado e determinado, enfim, como finito. O significado desta contradição, entretanto, depende do modo como a própria operação da reflexão é compreendida. Hegel especifica os dois modos distintos de compreensão da reflexão nessa mediação exigida pela filosofia:

"A reflexão isolada, enquanto pôr de contrapostos [als Setzen Entgegengesetzter] seria um suprimir do absoluto ela é a faculdade do ser e da limitação. Porém a reflexão enquanto razão tem uma relação com o absoluto e só é razão através dessa relação" (DS, p. 26).

"Reflexão isolada" (isolierte Reflexion) é aquela que produz as determinações abstratas do entendimento, produz as cisões e, está de acordo com o sentido tradicional da reflexão intensamente atacado por Hegel em Frankfurt. A reflexão é isolada porque isola seus produtos do absoluto, fixando-os cada um como em si mesmo distinto e em si mesmo absoluto. Ela é, portanto, uma reflexão isolante, e isto na medida em que o que a caracteriza é apenas a atividade de cindir e de instaurar separações e limitações. Por essa razão Hegel a denomina de "faculdade da limitação" (Vermögen der Beschränkung). Para essa reflexão aprisionada ao "ponto de vista da cisão", a mediação da contradição exigida pela construção do absoluto para a consciência é uma tarefa infinita jamais inteiramente realizável, pois toda forma de posição do absoluto é, para ela, a sua determinação como finito; e é por essa razão que Hegel afirma que a reflexão finita, permanecendo um raciocinar negativo, não pode chegar jamais a ser filosofia. Para a reflexão filosófica que opera compreendendo sua atividade enquanto "reflexão isolada", "a síntese absoluta é um além" e deverá assim permanecer indefinidamente.

Entretanto, a partir da perspectiva que reconhece a razão como absoluta e faz de seu conhecer um conhecimento efetivo do absoluto, a reflexão é desde o início tomada enquanto razão (als Vernunft), e isso significa, não tomada como isolada mas enquanto mantendo uma relação com o absoluto. Essa maneira especulativa de compreender a reflexão reconhece a própria aniquilação da reflexão assim como de seus produtos na 
medida em que se relaciona e os relaciona ao absoluto. A idéia de uma auto-aniquilação da reflexão não é inteiramente nova nos escritos de Hegel, pois, como vimos, a operação da reflexão já era reconhecida em Frankfurt como podendo levar o entendimento ao seu desmantelamento ${ }^{311}$. O que é novo em relação a essa Selbstvernichtung da reflexão especulativa é a perspectiva da relação ao absoluto (Beziehung auf das Absolute) na própria operação de aniquilação, e isso na medida em que ela é reconhecida, simultaneamente, como a afirmação da subsistência das separações instauradas pela reflexão enquanto suprimidas em sua relação com o absoluto.

"A reflexão aniquila-se a si mesma e a todo ser e a tudo o que é limitado, na medida em que o relaciona com o absoluto. Mas ao mesmo tempo, precisamente através da sua relação com o absoluto, o limitado tem uma subsistência [das Beschränkte hat ein Bestehen]" (DS, p. 26).

A partir do ponto de vista do entendimento o "relacionar com o absoluto" é apenas uma exigência formal que o mantém absolutamente contraposto às determinidades finitas, isto é, uma negação simples de toda determinação. Se o absoluto não é assim conquistado, ele é ao menos transferido para um além que o preserva do nada resultante da negação do limitado. Esse é o modo pelo qual o entendimento, mais intimamente ligado ao mistério e a fé do que entende ser, se resguarda em relação àquilo que para ele é experimentado como "horror" (Greuel). Pois do contrário o entendimento teria de admitir a "destruição do divino" e de tudo que lhe é sagrado, uma vez que da negação simples, única forma de negação reconhecida pelo pensar finito, nada resulta.

Entretanto, da perspectiva da reflexão como razão, a auto-aniquilação tem inteiramente outro significado e não se apresenta somente como "força do absoluto negativo" (Kraft des negativen Absoluten), que o faria permanecer em uma infinitude negativa, mas apresenta-se "simultaneamente como força do pôr da totalidade dos contrapostos subjetivo e objetivo" (DS, p. 26). Enquanto determinações finitamente fixadas, sujeito e objeto permanecem, de tal forma contrapostos, para o conhecer em sua compreensão finita, que a sua suposta unificação apenas pode representar a aniquilação de um dos termos, e a unidade absoluta apenas uma idéia a ser alcançada através da

${ }^{311}$ Cf. Hegel, GCh, HW I, p. 380. 
negação abstrata exercida pelo sujeito ${ }^{312}$. Se, porém, a razão é reconhecida, simultaneamente, como Kraft des Setzens, ou seja, não apenas negação do finito, mas também em sua atividade de relacionar os termos separados ao absoluto, então a reflexão filosófica se eleva a um pensar racional, tornando-se saber: a identidade do subjetivo e do objetivo no absoluto. "Na identidade absoluta, o sujeito e o objeto são suprimidos [aufgehoben]; mas, porque eles estão na identidade absoluta, simultaneamente subsistem, e é essa subsistência de ambos que torna possível o saber, pois no saber é posta, em parte, a separação [Trennung] entre ambos" (DS, p. 95).

A interpretação da atividade da reflexão como uma atividade da razão significa a sua compreensão como não sendo somente uma atividade separadora que, na sua operação de conhecimento, fixa seus produtos finitos como determinações absolutas. E que, enquanto negação racional, não é considerada um aniquilar que elimina definitivamente as determinações que se contrapõem. "A filosofia deve conceder o seu direito à separação entre sujeito e objeto" (DS, pp. 94-5), escreve Hegel indicando que essa modalidade superior da reflexão filosófica não é uma supressão da identidade e do absoluto, assim como o "conhecimento" isolado dos termos finitos distintamente por ela fixados é um erro (Irrtum), pois isto seria somente a afirmação de uma separação, quando toda forma possível de conhecimento é simultaneamente a expressão de uma identidade. A especulação filosófica exige assim o reconhecimento da identidade, no absoluto, das próprias operações contraditórias da reflexão: “contrapor e ser-um [Einsein] estão simultaneamente no absoluto".

"Na medida em que a filosofia separa [trennt], não pode pôr os separados [die Getrennten] sem os pôr no absoluto; pois, de outro modo, eles são puramente contrapostos, que não têm nenhuma outra característica senão a de um não ser enquanto o outro é. Esta referência ao absoluto não é, de novo, a supressão de ambos, pois assim não seriam separados; pelo contrário, devem permanecer como separados e não perder este caráter, na medida em que são postos no absoluto e o absoluto é posto neles" (DS, p. 96).

312 "Quando a supressão da cisão é posta como tarefa formal da filosofia, a razão pode tentar resolver a tarefa aniquilando um dos contrapostos e elevando o outro ao infinito". Hegel, DS, p.94-95. 
Trata-se aqui da identidade de contrários que Hegel encontrava expressa na vida e que, no Systemfragment, buscara apreender dialeticamente através da expressão "ligação da ligação e da não ligação". Como agora essa apreensão é reconhecida enquanto efetivamente um conhecimento, Hegel pode exprimir essa identidade absoluta como "a identidade da identidade e da não identidade", isto é, uma identidade no interior da qual há uma subsistência dos termos que nela foram suprimidos. Esta identidade absoluta é a própria razão, considerada como sendo em si mesma sintética, ou seja, como uma atividade de posição (Setzung) da identidade de contrário que os conserva enquanto suprimidos na unidade. Conseqüência disso é que todas as limitações e determinações finitas não são mais tomadas como formas absolutas, mas ao contrário, são reconhecidas de forma absoluta como manifestação do próprio absoluto. "A ação de suprimir [das Tun des Aufhebens] aniquila o posto apenas em sua absolutidade, ou na sua pretensão de ser ele mesmo o absoluto. E é precisamente através desta ação que o reconhece de maneira absoluta" ${ }^{313}$. Em outras palavras, o que agora se entende por conhecer (Erkenntnis) não é mais a atividade de instauração da separação na consciência realizada pelo entendimento unilateralmente compreendida, mas o reconhecimento, enquanto atividade exclusiva da razão, da totalidade em que estão unidos os termos limitados instaurados pela separação. É somente nessa medida que é possível falar em "conhecimento do absoluto", pois todas as determinações resultantes da operação da reflexão, ao serem relacionadas ao absoluto, são reconhecidas como "manifestação do absoluto" (Erscheinung des Absoluten), de modo que, nesta unidade reconstruída, "a cisão entre o absoluto e a totalidade das limitações desapareceu" (DS, p. 21).

Esta "atividade da razão" (Tätigkeit der Vernunft) é, para o pensar do entendimento, um simples "negar racional" do finito, uma atividade exclusivamente separadora" (trennende Tätigkeit) que tem por conseqüência a contraposição de um infinito como seu produto - um infinito enquanto idéia. Somente lhe aparece "o lado aniquilador da especulação" e o entendimento não pode reconhecer a positividade de sua operação de negação, isto é, apreender que "a noite da mera reflexão e do entendimento raciocinante" é simultaneamente "o meio-dia da vida" (DS, p. 35). A transformação do sentido da reflexão é, pois, um resultado deste zugleich especulativo, do reconhecimento

${ }^{313}$ Kroner, R. Von Kant bis Hegel, II, p. 155. 
racional da contradição como expressão mesma do absoluto. Mas o sentido positivo da contradição, a afirmação de que ela é a "regula veri" do conhecimento do absoluto, como Hegel escreverá na suas Habilitationsthesen ${ }^{314}$, disso apenas se pode ter consciência "quando a especulação parte [ausgeht] da razão" e não toma a identidade abstrata do pensar como expressão única da verdade. (DS, p. 41).

Para as filosofias que partem do entendimento, da reflexão finita, a tarefa de construção do absoluto para a consciência permanece uma insolúvel contradição. A reflexão procura exprimir a identidade absoluta através de proposições formais em seus sistemas. O princípio de identidade $\mathrm{A}=\mathrm{A}$ é a proposição que elas elevam ao nível de um princípio absoluto do pensamento, mas ao fazê-lo excluem desta identidade toda desigualdade, e nesse sentido suprimem o absoluto como identidade do sujeito e do objeto. "Neste caso o princípio não é absoluto, mas carente, exprime apenas um conceito do entendimento, uma abstração" (DS, p. 36). Diante disto o pensar do entendimento apresenta uma segunda proposição para dar conta da diversidade: $\mathrm{A}=$ não $\mathrm{A}$, ou $\mathrm{A}=\mathrm{B}$, proposição que por sua vez põe termos distintos numa relação $(=)$, numa identidade meramente subjetiva e contingente exigida pela insuficiência da primeira proposição, abstraindo, portanto, da identidade do pensar $(\mathrm{A}=\mathrm{A})$. Ambas as proposições são unilaterais e estão condicionadas uma pela outra, como proposições que se contrapõem. “A primeira proposição é condicionada pela segunda, na medida em que subsiste através da abstração da desigualdade que a segunda contém; a segunda, na medida em que necessita de uma relação, para ser uma proposição" (DS, p. 38). Hegel afirma que ambas as proposições são proposições sobre a contradição; se a segunda expressa o próprio princípio de contradição, a primeira, afasta-se de toda contradição através de uma contraposição, ou seja, o princípio da identidade é também um princípio da não contradição. "Identidade e contradição são apenas exprimíveis enquanto em relação entre si nessas proposições, e essa relação é a negação ou abstração" ${ }^{315}$.

Nesse sentido é indiferente qual a proposição que a reflexão põe inicialmente com a pretensão de estabelecer um princípio absoluto, pois cada uma delas é em si mesma já

\footnotetext{
314 Conforme Hegel escreve na primeira de suas Habilitationsthesen, "Contradictio est regula veri, non contradictio, falsi". Texte zur Habilitation (1801). In: G. W. F. Hegel. Gesammelte Werke, Band 5, p. 227.

${ }^{315}$ Baum, M. Die Entstehung der hegelschen Dialektik, p. 105.
} 
uma relação com a outra. Essa relação entre proposições que mutuamente se contradizem é o que Hegel chama, empregando o termo kantiano, de antinomia. O reconhecimento de uma proposição (Satz) como uma antinomia, isto é, como uma "contradição que se suprime a si mesma" já implica, portanto, o reconhecimento de que todo suposto princípio (Grundsatz) absoluto posto pelo entendimento não corresponde à sua própria ilusão inicial de uma estabilidade não contraditória no topo do sistema que erige. É por essa razão que Hegel afirma ser a antinomia a "máxima expressão possível da razão através do entendimento" (DS, p. 39), pois ela manifesta ao entendimento a identidade absoluta enquanto pura negatividade ("absoluto negativo"), atestando assim a inadequação de sua operação finita em expressar positivamente a identidade absoluta.

Uma vez que a "lei do entendimento", o princípio de não contradição, exige a estabilidade de suas proposições, não pode haver, por parte do entendimento, uma compreensão racional da antinomia. A antinomia, afirma Hegel, é a "expressão formal da verdade", mas este seu sentido não pode ser apreendido pelo entendimento se ele ainda "não cresceu [gediehen] em direção à razão" (DS, p. 39). Isto é, o entendimento expressa formalmente o "saber e a verdade" precisamente quando enuncia a supressão de sua reflexão, quando apresenta a si mesmo a contradição suprimida e a não-verdade dos seus produtos finitos. Mas seu resultado é formal, carente de conteúdo, já que o entendimento não possui outra ferramenta senão o pensar analítico. $\mathrm{O}$ conteúdo de verdade que o entendimento expressa ao reconhecer o caráter antinômico de seus princípios permanece, então, para além de sua visão, e a auto-aniquilação da reflexão é, para ele, apenas a aparição negativa da razão. $\mathrm{Na}$ antinomia "a razão aparece puramente apenas do seu lado negativo, como suprimindo a reflexão, mas ela mesma não se apresenta em sua forma própria" (GuW, p. 320). Hegel tem aqui em vista as antinomias da razão pura apresentadas por Kant. Afirma ser "um lado importante da filosofia kantiana" o de ter reconhecido como a razão é por sua própria natureza levada a contradições, e de como estas resultam da aplicação das categorias do entendimento na determinação do infinito ${ }^{316}$. Hegel insiste, porém, no fato de que a filosofia de Kant, que subordina a razão ao pensar do entendimento, teria permanecido no seu "resultado

${ }^{316}$ Cf. Hegel, VGPh, HW XX, p. 353. E também, WdL, V, p. 216. 
negativo", sem poder reconhecer o "significado verdadeiro e positivo da antinomia" (Enzy, VIII, p. 128).

Essa visão míope do entendimento não o permite reconhecer a reflexão como ato da razão, que não apenas separa (reflexão isolada), mas simultaneamente relaciona as determinações que produz com o absoluto, aniquilando-as e simultaneamente deixando que as separações tenham nele uma subsistência. $\mathrm{O}$ entendimento não pode chegar assim a uma modalidade de conhecimento em que haja uma visão e um reconhecimento do resultado positivo que se apresenta na operação da reflexão, e, por isso, não há para ele nenhuma forma de conhecimento especulativo legitimo. Se a razão, por sua vez, pode chegar à especulação é porque seu conhecer não é mera reflexão, mas é também uma forma de 'visão' que compreende em uma unidade consciente os termos suprimidos na operação reflexiva, podendo assim os apreender em sua positividade. Devemos, pois, compreender o que permite que o trabalho da reflexão se torne consciente de sua atividade positiva, de modo que a "reflexão filosófica" possa ser efetivamente filosofia e não se restringir apenas a um "raciocinar negativo", uma negação abstrata das finitudes cujo resultado é um nada negativo. Uma vez que as determinações finitas foram aniquiladas, escreve Hegel, "falta, na verdade, o último ato [Akt] da reflexão fillosófica, a saber, a consciência da sua aniquilação" (DS, p. 34), isto é, precisamente aquilo que faz com que delas surja um saber. A pergunta a ser colocada é, portanto: o que constitui o "lado positivo" do saber, qual a instância responsável pelo recolhimento e reconhecimento da positividade resultante da obra da reflexão?

A continuação da frase em que Hegel apresenta a tarefa da filosofia apresenta o início de uma resposta. "Deve-se preferencialmente mostrar em que medida a reflexão é capaz de apreender o absoluto e como, no seu trabalho como especulação, suporta a necessidade e a possibilidade de ser sintetizada com a intuição absoluta..." (DS, pp. 2526) ${ }^{317}$. Reconhecido o trabalho da reflexão como razão, para a qual toda separação é simultaneamente considerada em sua relação ao absoluto, é necessária uma instância que possa suportar a cisão na medida em que é pensada como identidade. Esta atividade da razão fundamental ao saber especulativo, tal como Hegel o concebe em sua primeira caracterização em Jena, é chamada de intuição transcendental (transzendentale

${ }^{317}$ O grifo é de nossa autoria. 
Anschauung) ou intuição absoluta. Sem a intuição, o aprofundamento da reflexão não poderia ultrapassar a dimensão da sua autodestruição, de modo a jamais se tornar um saber positivo do absoluto. Não haveria como falar propriamente em construção do absoluto se não houvesse uma real apresentação (Darstellung) sua no interior do âmbito da consciência.

A tarefa de conhecer o absoluto, posta sob a forma da reflexão enquanto a sua construção para a consciência, tem de ser, portanto, o resultado de uma sintese do trabalho da reflexão e da intuição, e "o saber especulativo deve ser compreendido como identidade da reflexão e da intuição" (DS, p. 43). Somente a partir disto é que a filosofia pode estar à altura de sua tarefa, pois nem permanece na não-identidade do raciocinar finito, o qual não pode contemplar a identidade absoluta, tampouco se restringe àquela não-identidade do sentimento religioso, na qual sua contemplação não pode se tornar consciente, não pode se tornar um saber. A intuição garante ao pensamento o afastamento de uma reflexão meramente formal e permite recuperar a identidade absoluta do interior da multiplicidade de contraposições suprimidas pelo trabalho da reflexão. Filosofar sem intuição significaria, portanto, "destruir-se a si mesmo infinitamente em finitudes absolutas", pois seria uma forma de progredir em "uma série infinita de finitudes" sem jamais encontrar um termo (DS, pp. 42-43). Sem a intuição transcendental, a filosofia seria uma "tarefa infinita", tal como Hegel reconhece ocorrer na filosofia kantiana que não pode efetivamente realizar a idéia da razão e sua exigência de absoluta totalidade, totalidade incondicionada da cadeia de condições (finitudes) no mundo sensível. Não é por acaso que Hegel também empregue a palavra "tarefa" (Aufgabe) ao falar da filosofia em sua busca de conhecer o absoluto. Entretanto, compreende esta tarefa especulativamente, e isto quer dizer, não como a exigência formal de um máximo para completar a série de condições no mundo sensível ${ }^{318}$ - tarefa jamais plenamente realizável -, mas como a construção efetiva do absoluto para a consciência como especulação, identidade da reflexão e intuição.

A mesma forma de reinterpretação especulativa está em jogo na utilização que Hegel faz do termo intuição, conceito chave da teoria kantiana do conhecimento. Em Kant, as formas da intuição constituem uma das condições de possibilidade do

${ }^{318}$ Cf. Kant, KrV, B536. 
conhecimento, sendo a outra condição os conceitos puros do entendimento. A separação entre conceito e intuição é uma obra da reflexão crítica. Hegel reconhece na base da filosofia de Kant esta cisão fixada de forma absoluta, de modo que haveria de um lado "o puro saber (que seria o saber sem intuição)", para o qual o máximo resultado é a aniquilação da contraposição, e, de outro, uma intuição pura, isto é, empiricamente dada, sem a passagem pela contraposição, e portanto, "carente de consciência" (bewußtlos). É por isso que Hegel chama a intuição própria ao saber especulativo de "intuição transcendental", pois aquilo que ela reúne em sua 'visão' não é um saber formal que abstrai de um dos seus lados constitutivos, mas um "saber transcendental" que "unifica ambos, a reflexão e a intuição; é conceito e ser simultaneamente [zugleich]" (DS, p. 42).

Hegel tem em vista que Kant havia negado, "ao menos para nós homens", uma intuição intelectual (intellektuelle Anschauung) para a qual fosse "dada a própria existência do objeto da intuição" ( $\mathrm{KrV}, \mathrm{B} 72)$, e que assim legitimasse o uso transcendental das categorias, o conhecimento especulativo que a reflexão crítica deveria restringir. Como, segundo Kant, um "entendimento intuitivo" é uma mera idéia da razão finita, de cuja possibilidade não possuímos nenhum conceito, a cisão entre intuir e pensar permanece o limite último para a filosofia crítica, sem haver como chegar ao absoluto entendido como identidade do ser e do pensar. Ao escrever, todavia, que a especulação é um saber transcendental, conceito e ser simultaneamente, Hegel pretende com isso indicar como o saber filosófico não se encontra restringido ao conhecer finito de uma subjetividade contraposta à objetividade (inteligência contraposta ao ser, liberdade contraposta à necessidade), mas, pelo contrário, é um conhecer absoluto em que "o ser e a inteligência se encontram unidos" (DS, p. 42). As formas da intuição não são, portanto, meras formas subjetivas de intuir, mas são simultaneamente formas do ser ${ }^{319}$.

Assim sendo, se para Kant a especulação tinha sua origem no "focus imaginarius" que levava a razão à ilusão de admitir um objeto a ele correspondente, Hegel apresenta a especulação, fazendo referência a isso, como o reconhecimento, através da intuição transcendental, do foco infinito para onde as finitudes instauradas pela reflexão são reconduzidas:

${ }^{319}$ Cf. Dottori, op. cit., p. 144. 
"Para a especulação, as finitudes são raios de um foco infinito, que as irradia e simultaneamente é composto por elas; o foco é posto nelas e elas no foco. $\mathrm{Na}$ intuição transcendental toda contraposição é suprimida, e é aniquilada toda a diferença da construção do universo pela e para a inteligência, e sua organização que aparece como independente e intuída como objetiva. O produzir da consciência desta identidade é a especulação, e porque a idealidade e a realidade são um só nela, ela é intuição" (DS, p. 43).

Esta intuição somente é conhecimento porque reúne na totalidade infinita, identidade do finito e infinito, as separações e determinidades produzidas pela reflexão. Sem o trabalho da reflexão, não há como chegar à intuição transcendental e assim ao saber especulativo. A intuição não pode ser, portanto, um simples ponto de partida, como a Tathandlung de Fichte, em que se abstrai de toda multiplicidade, nem também uma suposta forma de conhecimento imediato que abstraia da reflexão e permaneça assim à ela contraposta ${ }^{320}$. Nesse sentido, o conhecimento do absoluto como a construção do absoluto na consciência se distancia do conhecer intuitivo da Darstellung meines Systems der Philosophie de Schelling ${ }^{321}$.

A intuição transcendental, conforme Hegel apresenta em 1801, é assim a apreensão daquilo que se apresenta enquanto resultado do trabalho especulativo da reflexão. Ela apenas pode apresentar a identidade dos contrários a partir da atuação da reflexão. Porém, a especulação deve ser compreendida como a síntese da reflexão e da intuição e não a simples soma de ambos, como se a intuição fosse um simples acréscimo que deve ser feito à operação da reflexão. Se a intuição transcendental for assim entendida, isto é, como um simples postulado da razão, um complemento que a razão exige para superar a unilateralidade da reflexão, isto significaria que a reflexão da qual se parte é aquela do entendimento, compreendida desde o princípio como finita. Uma tal maneira de proceder estaria sempre atrasada em relação à unidade que se pretende conhecer, e sua perseguição seria necessariamente sem sucesso, pois a razão fora posta, de início, como "algo que não se basta a si mesmo, mas sim como algo necessitado" (DS,

\footnotetext{
320 "Este ato absoluto da livre auto-atividade é a condição do saber filosófico, mas ainda não é a própria filosofia". Hegel, DS, p.54.

${ }^{321}$ Cf. Fujita, M, Philosophie und Religion beim jungen Hegel, p.167.
} 
p. 44). A intuição deve ser, pelo contrário, reconhecida na identidade com a reflexão e apenas assim a razão pode se conhecer de maneira absoluta. "Ela não postula um deles, pois põe imediatamente ambos com a absolutidade [Absolutheit], e a absolutidade da razão não é senão a identidade de ambos” (DS, p. 45).

Vemos assim como a apresentação desta forma de conhecer chamada de especulação se caracteriza pelo reconhecimento do trabalho positivo da reflexão na sua identidade com a intuição transcendental. O absoluto, identidade absoluta e incondicionada do sujeito e do objeto, não é o resultado puramente negativo da aniquilação das finitudes como ocorre numa filosofia que eleva o sujeito ao infinito e que mantém o campo objetivo como um contraposto negado - resultado que não deixa de se aproximar daquele alcançado pelo ceticismo moderno ${ }^{322}-$, mas, antes, o absoluto é o "o negativo em sua verdade" (VGPh, HW XIX, p. 359), a negação determinada de ambos, sujeito e objeto como instâncias autônomas e o reconhecimento de sua subsistência na identidade de ambos. A especulação exige, portanto, uma re-significação da idéia de supressão (Aufhebung), que não é mais compreendida como a negação simples dos termos contrapostos resultando em um nada, nem como a negação abstrata de uma das partes expressa por um dever (Sollen); a supressão especulativa, que será apresentada de maneira clara em 1807, é uma forma de negação ${ }^{323}$ que reconhece os contrapostos desde o início como momentos ideais da unidade absoluta, uma negação que no seu processo eleva os termos à sua verdade. $\mathrm{O}$ absoluto que é conhecido pela razão é, portanto, a verdadeira infinitude não contraposta às finitudes, mas na qual as fixas determinações finitas são suprimidas e reconhecidas como manifestação do absoluto, isto é, como posições do próprio absoluto ${ }^{324}$.

Damos assim um passo importante na compreensão do sentido da construção do absoluto para a consciência, reconhecendo em que medida a reflexão participa positivamente de seu conhecimento. O saber transcendental alcançado pela especulação é uma "totalidade do saber produzida pela reflexão" (DS, p. 35), um sistema que, enquanto uma "totalidade orgânica", não tem o entendimento separador como sua lei suprema.

${ }^{322}$ Cf. Hegel, Verhältniß des Skepticismus zur Philosophie (VSPh), HW II.

323 A elaboração das formas de negação Hegel apresentará mais tarde, na Phänomenologie des Geistes (cf. PhG, HW III, p. 74) e na Wissenschaft der Logik (Cf. WdL, HW V, p. 49).

${ }^{324}$ Cf. Dottori, op. cit, p. 137. 
Hegel está transferindo para o saber a relação orgânica (viva) entre as partes e o todo que reconhecia no modo de ser da vida ${ }^{325}$. O saber racional é um "um sistema da ciência" (System der Wissenschaft) e seu caráter sistemático é o resultado da reflexão sob a perspectiva da razão. Nenhum conhecimento isolado (finito) possui subsistência, verdade em si mesmo - como querem os sistemas que pretendem derivar a totalidade do saber de uma única proposição ou definição ${ }^{326}$; cada saber somente é verdadeiro na sua relação com o absoluto, como parte de uma organização. Como escreve M. Baum, "na organização do saber domina a mesma estrutura que na vivacidade do vivo - esse pensamento da identidade de estrutura da reflexão e seu objeto explica em resumo e provisoriamente a nova posição de Hegel em relação à cognoscibilidade do absoluto" 327 .

Vemos, assim, como a organização deixa de ser o objeto ao qual a reflexão se dirige, tal como era o caso no Systemfragment, em que a reflexão se esforçava para exprimir o ser da vida, e passa agora a constituir a própria forma que a reflexão assume ao se tornar instrumento de um saber efetivo do absoluto. O sistema da ciência, saber vivo, é a própria atividade da razão, cuja auto-produção é uma "pura exposição de si mesma". "Nesta auto-produção da razão, o absoluto configura-se numa totalidade objetiva, uma totalidade em si mesma produzida e acabada, que não tem nenhum fundamento fora de si, mas que se funda a si mesma no seu início, no seu meio e no seu fim” (DS, p. 46). O caráter sistemático do saber não é uma totalidade do conhecimento como idéia, tal como encontrávamos enunciado de maneira formal na filosofia kantiana, mas o próprio modo com que a totalidade característica do absoluto se manifesta a si mesma enquanto razão. Uma vez que o absoluto é a identidade reconstruída a partir da cisão, e esta é especulativamente compreendida como manifestação do próprio absoluto, o método do sistema da filosofia não será mais nem analítico (Reinhold/Bardili) nem sintético (Fichte), mas antes o "desenvolvimento da própria razão", prenunciando aquilo que será o cerne do movimento dialético de apresentação do espírito na Phänomenologie 328 .

325 "Uma filosofia verdadeira e viva deve se apresentar como uma grandeza viva que se desenvolve", Haering, T. Hegel. Sein Werk und sein Wollen, I, p. 616.

${ }^{326}$ Cf. Hegel, DS, pp. 35-41.

${ }^{327}$ Baum, M. op. cit, p. 96.

${ }^{328}$ Cf. Hegel, PhG, HW III, pp. 39-40. 
Vemos com isso que a reflexão e sua operação de separação é integrada como momento do próprio desenvolvimento do absoluto, e portanto necessária para o autoconhecimento da razão absoluta. Apenas na medida em que a reflexão é racionalmente compreendida é que ela pode ser elevada à especulação e, deixando de ser uma operação de limitação do conhecimento, tornar-se instrumento de um saber efetivo, positivo, do absoluto. Dessa forma é fundamental para a compreensão da especulação que percebamos que as duas formas de reflexão (reflexão do entendimento e reflexão como razão) não são operações em si mesmas absolutamente distintas, no sentido de que uma se oporia à outra, mas trata-se antes de duas formas distintas de interpretar o sentido da reflexão e de sua atividade ${ }^{329}$.

Hegel escreve que "não há nenhuma verdade da reflexão isolada, senão a da sua aniquilação" (DS, p. 30), querendo com isso mostrar a insustentabilidade do próprio modo de compreensão finita do procedimento da reflexão. Esse ponto é essencial para tarefa especulativa, pois a "reflexão especulativa", a verdadeira filosofia, não pode surgir de uma simples imposição interpretativa, mas deve encontrar o seu próprio nascimento na inconsistência da reflexão finita, de modo a indicar como a operação do entendimento nada mais é do que o resultado de uma interpretação fraca da própria razão. Ou seja, além do reconhecimento da ambigüidade do pensar concentrada na noção de reflexão, é necessário para a especulação o reconhecimento da razão como verdade do entendimento, pois apenas assim é possível uma real transição da reflexão crítica à filosofia especulativa, isto é, de uma filosofia do entendimento para uma filosofia da razão ${ }^{330}$. Este é o sentido de superação imanente que Hegel pretende em relação às "filosofias da reflexão", e em vista disso irá buscar no agir do entendimento o seu teor racional e especulativo, de modo a, através desse reconhecimento, sintetizar a "força do negar" e a "força do pôr", isto é, encontrar a positividade que surge a partir da negatividade da reflexão. Em outras palavras, o que Hegel pretende em sua leitura das

329 "Diesem unendliche Erkennen aber, oder der Spekulation aber steht das endliche Erkenne, oder die Reflexion gegenüber, nicht als ob beyde absolut einander entgegengesetzt wären, das endliche Erkennen, oder die Reflexion abstrahirt nur von der absoluten Identität desjenigen was in der vernünftigen Erkenntniß aufeinander bezogen, oder einander gleichgesetz ist, und durch diese Abstraktion allein, wird es ein endliches Erkennen". Hegel Fragmente aus Vorlesungsmanuskripten (1801/1802), Logica et Metaphysica, In: G. W. F. Hegel. Gesammelte Werke, Band 5, p. 271.

${ }^{330}$ Cf. Hegel, ÜWPhK, HW II, p. 182. 
"filosofias da reflexão", e na filosofia de Kant em particular, é fundamentalmente revelar como o modo finito de proceder do entendimento não é finito em sua atividade, mas na interpretação que dela faz assim como dos seus resultados. Isso pode se tornar manifesto ao se procurar a razão do agir do entendimento.

Hegel toma como exemplo a universalidade expressa pelos conceitos do entendimento. Ela nada mais exprime do que a totalidade que ele busca diante da multiplicidade sensível. O que Hegel pergunta é, pois, que totalidade é essa senão aquela que, na medida em que caminha ao infinito, "eleva o entendimento para além dele mesmo" exigindo dele uma unidade última e incondicionada à qual ele jamais poderia chegar, e desta forma aniquilando-o? Vejamos como isso se dá: "cada ser, na medida em que é posto, é um contraposto, é condicionado e condicionante; o entendimento completa estas suas limitações através das limitações opostas, como condições” (DS, p. 26). Esse modo de proceder em busca da totalidade de condições, que vimos descrito em Kant, é uma tarefa do entendimento e ele opera puramente numa simples reflexão do entendimento, correto? Da perspectiva do próprio entendimento, responde-se a isso afirmativamente. Porém, da perspectiva da razão, o caráter de entendimento dessa reflexão é apenas uma primeira "aparência" ${ }^{331}$, uma vez que "essa condução para a totalidade da necessidade é a participação e a atuação secreta da razão" (DS, p. 26) e que caminha inevitavelmente no sentido do declínio (Untergang) do entendimento. Hegel reconhece ser um grande mérito da filosofia kantiana ter indicado que o próprio procedimento da reflexão do entendimento não se sustenta em si mesmo, o que significa a partir da perspectiva especulativa, que sua atividade tende à sua própria supressão na razão:

"Cada ser que o entendimento produz, é um ser determinado, e o determinado tem o indeterminado diante de si e atrás de si, e a multiplicidade do ser encontra-se entre estas duas noites, sem conseguir se manter [haltungslos]; ela repousa no nada, pois o indeterminado é nada para o entendimento, e acaba no nada" (DS, p. 26).

O fato de que o resultado da operação do entendimento o conduza para além de si mesmo, para sua supressão, é o indício de que ele não opera cegamente, mas que sua

331 “Die Reflexion scheint hierin nur verständig...” Hegel, DS, p.26. 
reflexão é, desde o início, orientada através da razão. É por isso que Hegel pode escrever que essa "teoria do entendimento é apadrinhada pela razão" (DS, p. 10), pois através do entendimento esta opera secretamente, mas quando se encontra rebaixada na figura do entendimento não pode compreender sua própria origem. A razão "seduz" (verführt) o entendimento a agir conforme seu próprio interesse, e é por esse motivo que ele é levado, através de sua lógica própria, a se reconhecer como sem fronteiras, suspenso em um indeterminado nada. Para o próprio entendimento, que "não tem qualquer notícia do trabalho especulativo" (DS, p. 33), esse nada é vazio e representa sua própria supressão em uma pura negatividade, pois não é capaz de ver o lado positivo de sua operação, a relação com o absoluto. O entendimento apenas poderá se tornar razão quando fizer da "lei suprema" que a razão lhe fornece, e que o conduz à sua aniquilação, sua própria lei o que não significa outra coisa que assumir positivamente seu auto-aniquilamento. Em outras palavras, a perspectiva especulativa deve atacar "a lei imanente" do entendimento, o princípio de contradição que não pode reconhecer o lado positivo da antinomia e que torna absoluta a interpretação não racional da reflexão, fixando "os produtos como absolutamente contrapostos ao absoluto" (DS, p. 28). Essa maneira de fixar o agir da razão na contraposição é o que caracteriza o raciocinar negativo, a reflexão finita do entendimento, e que deve ser especulativamente suprimida para tornar-se especulação.

A "reflexão comum", que Hegel associa diretamente ao modo de pensar do são entendimento, ou entendimento comum, não é capaz por si mesma, a partir de seu ponto de vista, de se elevar acima de si mesma. Sem a perspectiva racional sobre sua atividade, a reflexão finita permanece presa no lado negativo do saber, prosseguindo infinitamente na cadeia de determinações, buscando para todo condicionado sua condição, e mantendo os contrapostos "lado a lado" (nebeneinander) por unificar. Como "o absoluto não é nenhum lado a lado [Das Absolute ist kein Nebeneinander]" (DS, p. 56), o entendimento não pode apreender aquilo que há de racional em sua atividade, a relação da reflexão $e$ de seus produtos com o absoluto, reduzindo-a a seu caráter meramente isolador. $\mathrm{O}$ entendimento não apenas não pode compreender a especulação, como esta tem de lhe aparecer sempre como contraditória, isto é, como não possuindo um conteúdo positivo. Isto porque, ao lado positivo do saber o entendimento finito não tem acesso, pois não pode intuir, e, dessa forma, não possui nenhum conceito positivo do infinito. É por isso 
que Hegel chega a falar que o são entendimento "deve odiar a especulação quando dela faz experiência", pois esta afirma positivamente, como saber, uma síntese de termos que para ele permanecem contrapostos e de cuja unidade ele apenas possui um indeterminado sentimento. Se através de sua própria atividade o entendimento apresenta sua própria supressão, não pode ainda se reconhecer como razão, na medida em que permanece preso à sua perspectiva unilateral (apenas analítica). A possibilidade da elevação do entendimento à razão não depende, portanto, de uma recusa da atividade do entendimento, mas sim de uma superação da interpretação unilateral que dela o próprio entendimento possui.

"A especulação reconhece como realidade do conhecimento apenas o ser do conhecimento na totalidade; tudo o que é determinado tem, para ela, apenas realidade e verdade na relação conhecida com o absoluto. Por isso, ela reconhece também o absoluto naquilo que subjaz às sentenças do são entendimento humano" (DS, p. 31).

A "teimosia" à qual o entendimento está assim aferrado se caracteriza, portanto, pela interpretação que absolutiza a cisão e toma a contradição como um limite negativo para o pensar, cristalizando-o numa contraposição em relação à positividade de uma intuição. "A reflexão, enquanto entendimento [als Verstand] é em si e por si incapaz de apreender a intuição transcendental" (DS, p. 101). Cabe à reflexão filosófica, à filosofia especulativa, reconhecer a estreiteza desta obstinada perspectiva do entendimento, e ao indicar a sua unilateralidade, reconhecer racionalmente o conteúdo de verdade que ela expressa, mas que depende da especulação para ser positivamente apreendida. Se em Kant a reflexão crítica deveria conter as pretensões do conhecimento especulativo (trabalho negativo da reflexão), e toda forma de positividade desta reflexão na esfera do conhecimento seria reconduzida aos limites de uma subjetividade finita, em Hegel, por sua vez, será a própria especulação que transformará a reflexão finita em reflexão especulativa, atividade positiva de conhecimento.

Esta é a perspectiva que orienta toda a leitura que Hegel faz da filosofia de Kant através do conceito de especulação, que fora conquistado a partir das insuficiências do próprio pensar reflexivo na apreensão e expressão do absoluto. A leitura especulativa hegeliana pretende, dessa forma, revelar os aspectos racionais que o sistema kantiano não 
pôde sustentar na medida em que rebaixou a razão ao nível do entendimento, e que, diante da ambigüidade do pensar, não reconheceu a reflexão como atividade absoluta da razão, como reflexão especulativa, mas tomou o refletir, unilateralmente, em seu aspecto finito. Nas palavras de Hegel:

"Kant tem aqui ambos diante de si: a idéia de uma razão, na qual possibilidade e realidade são absolutamente idênticas, e a aparição [Erscheinung] das mesmas enquanto faculdades do conhecimento [Erkenntnisvermögen], na qual elas estão separadas. Ele encontra ambos os pensamentos na experiência de seu pensar, mas na escolha entre eles, sua natureza desprezou a necessidade de pensar o racional, uma espontaneidade intuitiva e decidiu-se pura e simplesmente pela aparição" (GuW, p. 326; o grifo é de nossa autoria).

\section{Reflexão e a semente do especulativo}

"Reconstruir um kantismo bem centrado é desde já desconhecer, na obra, o seu quinhão de incerteza e indecisão" (Lebrun, G. Kant e o fim da metafisica, p. 388)

Vimos como Hegel reconhece que a atividade do entendimento já opera a partir de uma orientação racional que, no entanto, o próprio entendimento não é capaz de apreender. A possibilidade de o entendimento elevar-se sobre si mesmo, a possibilidade da aniquilação da fixidez das determinações finitas e sua simultânea subsistência na totalidade infinita, assim como o reconhecimento do estatuto positivo da reflexão no conhecimento do absoluto a partir dos impasses da reflexão finita, são as indicações de que uma filosofia do entendimento apresenta princípios especulativos que ela mesma não pode apreender no interior de seu sistema. $\mathrm{O}$ objetivo desta etapa final de nosso trabalho é o de indicar como o conceito hegeliano de especulação, que se origina a partir de um aprofundamento da reflexão crítica kantiana, permite simultaneamente mapear e indicar os aspectos especulativos que não puderam ser desenvolvidos na filosofia de Kant devido 
aos pressupostos críticos que nela orientam a operação da reflexão. Retomamos assim a leitura que Hegel faz da filosofia de Kant em 1802, porém agora através do conceito de especulação que fora conquistado ao longo de nosso percurso.

Já pudemos indicar em linhas gerais como Hegel detecta que a operação do entendimento é secretamente orientada pela razão, e como a compreensão racional dessa atividade depende da perspectiva especulativa que o filósofo desenvolve. Para que possamos por fim reconhecer aquilo que chamamos de "reinterpretação especulativa" da filosofia de Kant, iremos nos ater agora a alguns momentos centrais de sua leitura em $F e ́$ e Saber, tendo sempre como horizonte ressaltar a ambivalência que Hegel reconhece no do projeto kantiano, qual seja, a de que ele enuncia no interior de seu sistema a "semente do especulativo" (Keim des Spekulativen), que contudo, seu próprio sistema não pode reconhecer e desenvolver. Conforme Hyppolite nos escreve sobre essa perspectiva de leitura: "Hegel quis mostrar como todo o sistema kantiano convergiria em direção a uma idéia especulativa que Kant no final das contas recusa", 332.

Apenas a título de advertência, devemos ressaltar que nosso intuito aqui não é, de modo algum, o de esgotar os aspectos envolvidos na leitura que Hegel faz da filosofia kantiana neste ensaio, algo que exigiria, sem dúvida, outro extenso trabalho. Pretendemos apenas, através de alguns momentos maiores de sua leitura, ilustrar como a perspectiva especulativa pode reconhecer a idéia absoluta no próprio texto kantiano, e, simultaneamente, diagnosticar como a "linguagem da reflexão" que a orienta é incapaz de sustentá-la..

Neste ensaio de 1802 Hegel fala da possibilidade de "entrever" (erblicken) o espírito especulativo que habita as profundezas da qual todo empreendimento crítico emerge, desde que se parta, logo de início, do "ponto de vista superior da especulação" 333 . Isso significa permitir que o "princípio da filosofia" possa ir vá além do "princípio do sistema kantiano", de modo que ao invés de somente anunciar a idéia - irrealizável nos contornos críticos - do absoluto, possa reconhecer sua efetividade em figuras ali ainda não plenamente desenvolvidas. Vimos como Hegel já reconhecia em Frankfurt a

\footnotetext{
${ }_{332}^{33}$ Hyppolite, J. La Critique Hegelianne de la Reflexion Kantienne, p. 95.

${ }^{333}$ Cf. Hegel, GuW, p. 304; e também, Bouterweks Anfangsgründe der spekulativen Philosophie, HW II, p. 141
} 
"aparência enganosa dos juízos" 334 e indicava sua inadequação para exprimir a efetividade de uma idéia especulativa, exigindo uma outra forma de apreensão que não partilhasse dos pressupostos assumidos tacitamente pela "linguagem da reflexão". Não é por acaso que a figura do juízo (Urteil) receberá uma especial atenção quando se tratar de indicar aquilo que permanece inexpresso na filosofia de Kant; tendo-se em vista que é através do juízo que Kant apresenta o problema maior de sua filosofia.

Quando Kant concebe como estando expressa a "autêntica tarefa da razão pura" na questão "Como são possíveis juízos sintéticos a priori?”, o que ele está exprimindo, enfatiza Hegel, não é outra coisa senão "a idéia de que no juízo sintético sujeito e predicado, aquele o particular esse o universal, aquele na forma do ser, esse na forma do pensar - de que esse heterogêneo é simultaneamente a priori, isto é, absolutamente idêntico" (GuW, p. 304). Essa identidade "absoluta e originária de opostos”, que o juízo sintético a priori permite apenas vislumbrar, revela que aquilo que se apresenta habitualmente como separado, a saber, sensibilidade e entendimento, já se encontram em "uma e mesma unidade sintética" prévia a toda disjunção. Todavia, embora esse "já", característico dessa unidade a priori absoluta, possa ser entrevisto nesse tipo de juízo (Urteil), ele não pode aí se apresentar (darstellen) - e nem poderia, pois "o juízo ele mesmo é somente a aparição [Erscheinung] predominante da diferença" ${ }^{335}$. Hegel sublinha como no juízo o racional se manifesta mergulhado na oposição, e que

"a cópula [do juízo] não é um pensado, conhecido, mas exprime precisamente o não ser conhecido do racional; o que se manifesta e está na consciência é apenas o produto, enquanto membros da oposição: sujeito e predicado. E apenas eles estão postos na forma do juízo e não o seu ser uno [Einsein] como objeto do pensar" (GuW, p. 307).

\footnotetext{
${ }^{334}$ Cf . Hegel, GCh, HW I, p. 373.

${ }^{335}$ Hegel, GuW, p. 307. É importante notar que essa concepção de juízo que Hegel apresenta já apresenta uma distância em relação ao modo com que Kant o entende, e é claramente uma concepção mediada pela leitura que Hegel faz de Fichte, em que subjaz uma interpretação da consciência como o lócus da diferença, o ser separado (Getrenntsein) da unidade e multiplicidade, ao passo que para Kant a consciência reside, ao contrário, na própria unidade, síntese do múltiplo. A esse respeito escreve I. Görland: "Essa interpretação de Kant pressupõe uma estrutura da pura contraposição Eu-multiplicidade que enquanto tal não está presente em Kant e remete a Fichte. (...) De modo que para Kant o Juízo não é a aparição predominante da diferença oposta à unidade originária, mas somente através dos juízos surge uma unidade objetiva do múltiplo". Die Kantkritik des jungen Hegels, p. 27-28.
} 
A identidade do sujeito e do objeto é representada pela cópula 'é' que, entretanto, permanece "inconsciente" (Bewußtlose) no seu modo de apresentação na forma do juízo. Com isso Hegel pretende indicar a inadequação do modo de conhecimento que se expressa através da forma do juízo, e isto precisamente na medida em que ele não é capaz de sustentar o aparecer do absoluto na consciência ${ }^{336}$. É nesse sentido, que Hegel escreve que "a identidade racional da identidade [die vernünftige Identität der Identität], como do universal e do particular, é o inconsciente no juízo, e o juízo ele mesmo é apenas uma aparição do mesmo" (GuW, p. 307). Isto quer dizer o seguinte: o juízo é apenas capaz de expressar a identidade relativa do universal e do particular enquanto mergulhado na oposição, e a identidade racional é ocultada na medida em que a cópula não pode apreender (begreifen) reflexivamente aquilo que ela tem por base. É o que ocorre, de forma análoga, no caso da identidade indiferenciada da intuição, que deverá também permanecer inconsciente na medida em que não pode apresentar uma diferença interna reflexivamente reconhecível. O que falta em ambos os casos é, pois, a expressão e apreensão da "identidade racional da identidade" que seria a própria unidade refletida da identidade entre o universal do conceito e o particular da intuição, e que pode ser expresso na fórmula $\mathrm{A}^{2}=(\mathrm{A}=\mathrm{B})$. A possibilidade de apresentação consciente da identidade absoluta, do racional a priori que na forma do juízo permanece inconsciente, Hegel reconhecerá apenas na forma da "conclusão" $(S c h l u \beta)$, do conceito "intermediário" (Mittelbegriff) ${ }^{337}$, cujo sentido se esclarece a partir da interpretação que Hegel faz da unidade sintética originária da apercepção.

Até aqui, entretanto, podemos compreender em que sentido Hegel pode encontrar a aparição da idéia da razão, assim como sua simultânea não-apreensão na filosofia de Kant. A impossibilidade de uma apresentação real da identidade absoluta e originária na forma do juízo é o que parece ilustrar de modo mais nítido aquilo impede que a "semente do especulativo" possa se desabrochar livremente em uma filosofia que declara como unicamente possível o conhecimento finito, relegando ao Jenseits o conhecimento racional. Assim, se Kant diante da pergunta: 'Como são possíveis juízos sintéticos $a$

336 "Le jugement fait donc émerger la vérité sans la fonder" Cf. Hyppolite, J. La Critique Hegelianne de la Reflexion Kantienne, In: Kant-Studien, Band 45, Heft 1-4 (1953/54), p. 89.

${ }^{337}$ Vemos aqui como Hegel une a uma teoria do juízo uma metafísica da identidade absoluta. Cf. Baum, M. Die Entstehung der hegelschen Dialektik, p. 203. 
priori" "permaneceu apenas no seu significado subjetivo e exterior", o que o levaria inevitavelmente a concluir que "um conhecimento racional é impossível", Hegel volta-se para o que há de especulativo nessa pergunta perscrutando mais profundamente o que torna possível essa identidade entre a "aprioridade" e a "aposterioridade". Sua resposta será: “a possibilidade desse pôr [da identidade] é tão-somente a razão, que nada mais é senão a identidade dos desiguais" (GuW, p. 304). E, portanto, a razão não é mais considerada uma unidade pura, à qual se contraporia um mundo em si - o que nada mais significa senão tomá-la como ao nível de um entendimento que deve unificar entidades originariamente distintas -, mas como uma unidade em si mesma sintética, absoluta.

Hegel vai então mais longe do que a simples indicação daquilo que impede o reconhecimento da razão como atividade absoluta no sistema kantiano; ele está preocupado em mostrar como Kant pode "na verdade" (in Wahrheit) responder à questão da possibilidade dos juízos sintéticos a priori. "Na verdade", ou seja, de acordo com o fundamento racional dessa unidade efetiva que se manifesta inadequadamente no juízo sintético. "Eles são possíveis mediante a identidade absoluta originária do que é diverso [Ungleichartige], a partir do qual, como incondicionado, ela mesma se separa primeiramente como sujeito e predicado, particular e universal que aparecem separados na forma de um juízo" (GuW, p. 307). Se procurarmos então o lócus privilegiado no qual, segundo Hegel, é possível reconhecer o verdadeiro espírito da filosofia kantiana, isto é, ali onde a "idéia especulativa aparece [vorkommt]", devemos nos voltar para a "dedução das categorias", "onde ela surge em sua pureza" 338 . Como já vimos, seguindo uma via já enfatizada pela Wissenschaftslehre de 1794 de Fichte ${ }^{339}$, Hegel afirma que é nela dedução que se pode reconhecer um "autêntico idealismo", onde "está expresso da maneira mais determinada o princípio da especulação, a identidade de sujeito e objeto" (DS, p. 10). Em que sentido, porém, Hegel pode falar aqui de um autêntico idealismo (isto é, não um idealismo formal que recusa aquilo que pretende alcançar), e em que medida ele está presente na dedução das categorias?

\footnotetext{
338 "Em ambas [filosofia kantiana e jacobiana] aparece [vorkommt] a idéia especulativa; na filosofia kantiana ela surge em sua pura na dedução das categorias..." GuW, p. 388.

${ }^{339}$ Nossa proposição [a Tathandlung: A=A], como princípio absoluto de todo saber, foi indicada por Kant em sua dedução das categorias; porém ele nunca a estabeleceu determinantemente como princípio", Fichte, Grundlage der gesamten Wissenschaftslehre, GA I,2, p.262.
} 
A filosofia é um idealismo, escreve Hegel, na medida em que "na identidade absoluta, não reconhece como sendo por si nem um nem outro dos contrapostos em sua abstração do outro, mas a idéia suprema, indiferente em relação a ambos; e cada um dos contrapostos tomado isoladamente não é nada" (GuW, p. 302). Nesse sentido Hegel pode reconhecer o princípio idealista na filosofia de Kant: ela "tem o mérito de ser idealismo na medida em que demonstra que nem o conceito por si sozinho, nem a intuição por si sozinha são algo; a intuição por si é cega e o conceito por si é vazio" (GuW, p. 302). Uma vez que a tarefa da dedução transcendental, tal como enunciada por Kant, é justamente "o esclarecimento do modo pelo qual conceitos podem se referir a priori a objetos" (KrV, B117), ela necessariamente tem como cerne aquela identidade racional primeira, "a partir da qual se separam o eu, enquanto sujeito pensante, e o múltiplo, enquanto corpo e mundo" (GuW, p. 306-7). Contudo, na medida em que a identidade relativa da unidade e diferença se encontra restringida a doze categorias com sede fixa no entendimento, e uma vez que a aprioridade das categorias pode apenas consistir em sua aposteridade formal, a identidade cognoscível vê-se reduzida a um aspecto puramente formal e limitado, que inevitavelmente encontra diante de si uma "aposteridade absoluta", um "gigantesco império empírico da sensibilidade e percepção", como Hegel já escrevia no Differenzschrift. (DS, p. 10).

Dessa contraposição absoluta decorrente da forma que a dedução das categorias assume na filosofia de Kant, deve-se distinguir e apresentar o seu princípio especulativo, sublinha Hegel ${ }^{340}$. Pois caso contrário, o saber transcendental ver-se-á necessariamente transformado em um saber formal, para o qual a ligação (Verbindung) entre a identidade formal da categoria e a multiplicidade empírica será sempre incompreensível:

“À unidade da consciência de si - que é simultaneamente a unidade objetiva, a categoria, a identidade formal - a essa unidade deve-se ajuntar de maneira incompreensível e como um estranho [als ein Fremdes] um Plus do empírico não determinado por essa identidade" (GuW, p. 328-89).

340 “...essas circunstâncias residem no máximo na forma da dedução das categorias, não no seu princípio ou espírito”. DS, p. 10. 
Esse caráter de incompreensão (das Unbegreifliche) que reveste a ligação entre o uno e o múltiplo, acrescido do aspecto formal de todo saber possível Hegel reconhece como corolário necessário do já mencionado princípio da subjetividade que orienta toda a filosofia crítica. O termo "incompreensão" expressa bem a dinâmica da leitura que Hegel faz de Kant, pois apenas pode permanecer incompreendido em um sistema aquilo que de algum modo ali se expressa sem, contudo, poder ser conceitualmente apreendido (begriffen). Nesse sentido, a tarefa de uma reinterpretação especulativa da filosofia de Kant deve necessariamente conter ambos os movimentos: a indicação daquilo que ela contém de racional e não pode apresentar na forma de um saber, assim como, a denúncia dos pressupostos que impedem o seu reconhecimento, e seu conseqüente desenvolvimento.

Uma vez que a perspectiva especulativa tem como foco a idéia suprema (identidade absoluta da razão) - que é indiferente em relação aos pólos abstratos - e não a identidade relativa, contraposição absoluta na qual a filosofia kantiana "permanece" (verweilt), a verdadeira unidade sintética deve ser entendida não como "um agregado de multiplicidades tomadas em conjunto, à qual posteriormente ela se ajunta" ${ }^{341}$, mas um primeiro (das Erste) que seja originariamente sintético. Por isso Hegel reconhece o aparecimento da idéia da razão naquilo que Kant apresenta ora como imaginação produtiva (produktive Einbildungskraft), ora como entendimento intuitivo (anschauender Verstand ${ }^{342}$. Kant chamara de imaginação "a faculdade ativa de síntese do múltiplo", e distinguira a imaginação produtiva da imaginação reprodutiva, afirmando que enquanto esta se refere a uma síntese "submetida a leis meramente empíricas, as da associação", a primeira é caracterizada pela espontaneidade (Spontaneität) e é responsável pela síntese $a$ priori do múltiplo ${ }^{343}$. A imaginação produtiva, que na primeira edição da primeira Crítica aparece com grande ênfase como exercendo a síntese anteriormente à apercepção - sendo por isso chamada de "fundamento da possibilidade de todo conhecimento, em

\footnotetext{
341 Hegel, GuW, p. 306. A unidade sintética originária é "uma unidade que não deve ser compreendida como produto de opostos, mas como identidade originária, verdadeiramente necessária e absoluta de opostos...”, p. 305.

342 "...A idéia desse entendimento intuitivo arquetípico [urbildlicher, intuitiver Verstandes] não é de modo algum outra senão a mesma idéia da imaginação transcendental, que consideramos acima. (...) A imaginação transcendental é ela própria entendimento intuitivo”. GuW, p. 325.

${ }^{343}$ Cf. Kant, KrV, A120.
} 
particular da experiência" ( $\mathrm{KrV}, \mathrm{A} 118)$-, na medida em que é concebida como síntese $a$ priori do diverso, é exaltada por Hegel como idéia especulativa por excelência ${ }^{344}$. E como toda leitura da dedução das categorias deve ser lida a partir do que nela há de especulativo, a idéia da razão, manifesta na imaginação produtiva, torna-se a idéia suprema de toda dedução, cuja radicalidade deve ser ressaltada:

"Nada pode ser compreendido de toda a dedução transcendental, tanto das formas da intuição quanto da categoria, sem se diferenciar do eu, que é o sujeito que representa, chamado por Kant como aquele que apenas acompanha todas as representações, daquilo que Kant chama de faculdade da unidade sintética originária da apercepção, e sem reconhecer essa imaginação não como o termo médio que é inserido inicialmente entre um sujeito absoluto existente e um mundo existente absoluto, mas como aquilo que é o primeiro e o originário e a partir do qual tanto o eu subjetivo quanto o mundo subjetivo se separam primeiramente em uma bipartição necessária de fenômeno e produto, reconhecendo-a como o em-si. Essa imaginação, enquanto a identidade bilateral originária, que se torna de um lado sujeito em geral e de outro objeto, e que é originalmente ambos, não é outra coisa do que a razão mesma, cuja idéia já foi determinada, - apenas razão enquanto manifestando-se na esfera da consciência empírica" (GuW, p. 307-8).

Essa identificação que Hegel faz entre imaginação produtiva e razão implica no reconhecimento de que a imaginação não é meramente uma faculdade entre as demais, mas aquela raiz comum ${ }^{345}$ (identidade) a partir da qual entendimento e sensibilidade se diferenciam. Como afirma A. Stanguennec, "a imaginação é um tronco e não uma ponte para o entendimento e intuição" ${ }^{346}$, ela expressa a própria identidade absoluta do diverso, desde que seja apreendida enquanto originária, e não "na forma ordinária de faculdades

${ }^{344}$ Em relação a este ponto vale lembrar que a leitura hegeliana de Kant se encontra fortemente influenciada pela Wissenschaftslehre (1794) de Fichte que já havia ressaltado a importância dessa "faculdade, quase sempre subestimada, que compõe [zusammenknüpft] uma unidade a partir de constantes contraposições..." Fichte, Grundlage der Wissenschaftslehre, GA I,2, p. 350. Cf.. Rubens R. T. Filho, op. cit, pp. 89- 124.

${ }^{345}$ Cf. Kant, KrV, B29.

346 "Il est impossible pour le philosophe de concevoir l'imagination commo <l'intermédiaire> simplement introduit entre un sujet et un objet ayant tous deux une existence absolue, puisqu'elle est la véritable unité synthétique originaire: l'imagination est un tronc et non un pont pour l'entendement et l'intuition'. Stanguennec, A. Hegel critique de Kant. p. 103. 
psicológicas" (GuW, pp. 307-8) que funcionaria como simples termo médio de unificação de contrapostos dados. "Ao fato de ter colocado a idéia da verdadeira aprioridade na imaginação transcendental, escreve Hegel, a isso se deve atribuir o mérito de Kant” (GuW, p. 316). Através da idéia contida expressa pela imaginação transcendental, a filosofia de Kant faz violência ao seu sistema da reflexão e o "espírito da sua filosofia se mostra sob a sua forma mais pura e mais plenamente desligada de sua letra" ${ }^{347}$, letra de seu sistema.

Essa "idéia verdadeiramente especulativa" da imaginação produtiva é, pois, "a identidade absoluta, originária da consciência de si” que somente aparece à consciência na forma da identidade expressa no juízo, em que se encontram cindidos o eu enquanto identidade inteligível (sujeito pensante) e a multiplicidade (corpo e mundo). É por isso que a unidade originária da apercepção é dita sintética, isto é, devido à bilateralidade (Doppelseitigkeit) da imaginação produtiva que está em sua base, na qual “o contraposto é absolutamente um" (GuW, p. 306).

A mesma idéia especulativa da razão que se expressa silenciosamente na imaginação transcendental, Hegel reconhece presente na idéia de um entendimento intuitivo (anschauender Verstand), uma idéia da qual Kant se aproxima de enunciar, mas cuja efetividade se encontra por ele sempre recusada. Nela Hegel reconhece postos em uma unidade primeira - e portanto produtiva, isto é, enquanto princípio dos termos unificados - os aspectos da espontaneidade e da sensibilidade que serão posteriormente cindidos pela atividade crítica em faculdades distintas. Esse entendimento arquetípico representaria, pois, a identidade entre conceito e intuição, entre possibilidade e efetividade, para o qual haveria um conhecimento da conformidade a fins objetiva efetivamente na natureza, "uma unidade absolutamente inteligível e em si orgânica" (GuW, p. 327). Essa idéia expressa por Kant seria, segundo Hegel, uma superação da forma abstrata que sua razão teórica ou prática (entendimento) assume quando "destituída de uma ligação absoluta com as coisas". Como, porém, em Kant a única faculdade possível para um “conhecimento" não é outra senão o próprio entendimento, cuja reflexividade é sempre pensada no retorno à subjetividade finita, a idéia de um

${ }^{347}$ Hyppolite, J. La Critique Hegelianne de la Reflexion Kantienne, In: Kant-Studien, Band 45, Heft 1-4 (1953/54), p. 88. 
entendimento intuitivo permanece sem real efetividade, e não se reconhece o conhecimento racional em questão, destino do juízo reflexionante no interior da filosofia crítica.

Se, pois, Kant estava aqui diante da identidade absoluta, da idéia da razão, ele a toma, no entanto, sob a forma da identidade relativa do entendimento que, enquanto identidade pura e abstrata, se encontra contraposta à particularidade. Assim, Hegel censura Kant por ter feito "do verdadeiro a priori uma unidade pura, isto é, não originariamente sintética", e de por esse motivo não poder expressar efetivamente o em si (Ansich) de ambos, a identidade do entendimento e da multiplicidade empírica. De modo que "a filosofia não avança do juízo até a conclusão [Schluß] a priori, do reconhecimento de que é manifestação do em-si até o reconhecimento do em-si” (GuW, p. 309), mas deixa o âmbito das coisas em si como um absoluto destituído de objetividade e contraposto a um sujeito igualmente posto de forma absoluta.

Essa é a razão pela qual Hegel afirma ser o destino desta filosofia o de permanecer um "idealismo formal", em que se afirma um dualismo insuperável, "de um lado um ponto absoluto da egoidade e de seu entendimento e, de outro, a multiplicidade absoluto ou a sensação" (GuW, p. 313). Onde a razão parecia se elevar (erheben) acima do entendimento, "a idéia especulativa, que aparece de maneira mais viva na imaginação, já foi despotencializada [depotenzierte] pelo entendimento, e afunda junto à razão em uma identidade formal" (GuW, p. 317). Na medida em que o conhecimento desta identidade abstrata, que o entendimento expressa através das categorias, é considerado como o que há de mais elevado para essa razão, não há como a identidade absoluta ser reconhecida em sua aparição na figura da imaginação.

Em conseqüência disso, toda possível objetividade das categorias é reconduzida para o âmbito subjetivo e a razão é afirmada em sua finitude, como uma faculdade humana do conhecimento. Esse resultado não deixa de exprimir a verdade de que os objetos a que se dirige o conhecimento do entendimento nada mais são do que fenômenos, e portanto, nada em si mesmos. Mas Kant, insiste criticamente Hegel, não prossegue na "conclusão" (Schluß) especulativa que disso deveria tirar, a saber, "que um entendimento, que apenas conhece fenômenos e um nada em si, é ele também fenômeno e nada-em-si”, isto é, que o entendimento não se sustenta por si mesmo. Kant, porém, não 
podia assumi-lo: “o entendimento discursivo que assim conhece é considerado, ao contrário, como em si e absoluto, e o conhecimento dos fenômenos é dogmaticamente considerado como um único modo de conhecer, sendo negado o conhecimento da razão" (GuW, p. 313).

Esse "dogmatismo" que impede o reconhecimento da idéia da razão e que Hegel acusa em Kant é, como vimos, o da absolutização da finitude, uma pré-concepção da qual Kant nunca efetivamente se afastou: "que o entendimento seja o absoluto do espírito humano, disso Kant nunca duvidou. Porém o entendimento é a finitude absolutamente fixada da razão humana" (GuW, p. 313). E as conseqüências dessa admissão prévia são aquelas que vimos ao acompanhar a crítica de Hegel às filosofias da reflexão.

É a partir deste confronto da perspectiva especulativa - que tem diante de si a idéia da razão - e o sistema kantiano que não permite sua efetiva expressão que podemos compreender a reação de "perplexidade" presente na severa crítica hegeliana. Pois se, como insiste Hegel, da filosofia de Kant "é apenas interessante seguir esse seu lado verdadeiramente especulativo", o não desenvolvimento da semente especulativa tem de soar como uma "recaída", ou "malogro" ${ }^{348}$. Eis como Hegel expressa sua reação a partir do confronto com o destino da idéia da razão na filosofia de Kant: "é muito mais duro ver o racional não apenas novamente confundido, mas a idéia suprema ser com plena consciência destruída [verderbt] e a reflexão e o conhecer finito elevados acima dela" (GuW, p. 328). Toda a tarefa de uma reinterpretação da reflexão efetuada pela perspectiva especulativa pretende desfazer o pressuposto crítico que impede o desabrochar da idéia da razão.

Nesse sentido, a leitura que Hegel faz da filosofia de Kant visa indicar a possibilidade de uma transmutação do princípio interno das filosofias da reflexão, e da filosofia kantiana em particular, para a filosofia especulativa. De modo que a especulação não pode ser tomada como adversária da negatividade instaurada pelo projeto crítico; ao contrário, "a filosofia da infinitude [negativa] está mais próxima da filosofia do absoluto do que a [filosofia] da finitude" (GuW, p. 432), e pode se aproximar muito mais da idéia

${ }^{348}$ Lebrun, G. L'antinomie et son contenu, p. 534. 
da razão do que aquela "metafísica da objetividade" pré-crítica ${ }^{349}$. O que a filosofia especulativa combate é apenas a tendência, inevitável no interior do discurso crítico, de sua interpretação unilateral que acaba por fixar a infinitude no lado da subjetividade, estabelecendo com isso uma cisão irreconciliável. É nesse sentido, então, que Hegel pode afirmar que, do ponto de vista do interesse especulativo da razão, não há

"nada a evitar nestas filosofias da reflexão, senão que a infinitude, o eu, não se fixe novamente neste ponto e se torne subjetividade, tal como ocorre nestas filosofias, e ao invés de passar diretamente [überschlagen] ao positivo da idéia absoluta, que por meio disso recaiam novamente na antiga oposição e na completa finitude da reflexão, que ela mesma havia aniquilado anteriormente" (GuW, p. 431).

A especulação apenas não pode deixar de reconhecer que na base do "significado negativo do absoluto" se encontra a "idéia positiva de que o ser simplesmente não está fora do infinito, do eu, do pensamento, mas que ambos formam um" (GuW, p. 432). Não se trata, portanto, de forma alguma de uma recusa da virada transcendental, mas sim daquele pressuposto crítico que fundamenta a interpretação finita da reflexão, tomando-a como uma simples atividade de um sujeito finito, e não um momento do próprio absoluto.

O alargamento semântico efetuado no interior da ambigüidade reconhecida na filosofia kantiana depende, portanto, de uma perspectiva que se distancie do criticismo e não pretenda ser, ele mesmo, uma continuação do projeto kantiano, mas sua subversão para além dos contornos no interior dos quais foi erigido. "Forçar o pensamento finito" em direção a uma "outra dimensão teórica", como escreve D. Henrich ${ }^{350}$, não significa manter intacto o sistema de Kant para dele extrair o que ali não recebeu o devido desenvolvimento, mas, ao contrário, demonstrar a inconsistência interna presente em toda forma do pensar finito, desconstruindo os pilares da filosofia crítica que se sustentam sobre o solo último da finitude. Se a 'linguagem da especulação' não é a mesma que a "linguagem da reflexão", não é por recusar seus termos, mas, sobretudo, por não

\footnotetext{
349 "Sua crítica não se dirige de modo algum, como infelizmente ainda se afirma sobre ela, a um fazer retornar para aquém da 'virada crítica do modo de pensar', com o intuito de uma restituição da ontologia pré-crítica. Trata-se inteiramente do inverso: Hegel está neste ponto completamente de acordo com Kant". Burkhardt, B, Hegels Kritik an Kants theoretischer Philosophie, p.220.

${ }^{350}$ Henrich, D. Between Kant und Hegel, p. 312.
} 
compartilhar dos pressupostos que servem de horizonte à sua interpretação finita, que acabam por restringir a razão a uma atividade do entendimento humano.

Tratar a razão com razão é reconhecer que sua forma rebaixada (entendimento) não determina sua modalidade autêntica de conhecimento, e que sua verdadeira efetividade reside na especulação. Essa não tem mais diante de si aquele mundo imediato do senso-comum, tomado como um sistema fixo cindido em multiplicidades distintas. Sua realidade é uma totalidade concreta e dinâmica, universo espiritual entranhado pela negatividade que lhe fornece ininterrupto movimento, onde a liberdade encontra formas efetivas de realização. Para usar uma expressão tardia de Hegel, "o que é real é racional". 


\section{CONSIDERAÇÕES FINAIS}

Como um "Wendepunkt" ou até mesmo como um "ponto de partida absoluto" ${ }^{351}$, Hegel não deixará de reconhecer incontáveis méritos da filosofia de Kant. Se quisermos caracterizar a atitude de Hegel em relação à filosofia de Kant parece que encontramos uma boa expressão nas palavras de seu amigo de juventude, o poeta F. Hölderlin, quando afirma ser Kant um "Moisés da nossa nação". Pois se com Kant a filosofia pôde se libertar do antigo "dogmatismo do ser" e ser conduzida na livre travessia do deserto de sua reflexão filosófica, ela, no entanto, não teria conseguida efetivamente chegar à terra santa prometida. E é precisamente pela proximidade a que chega da "terra prometida", que ela pôde ser um ponto de partida para todos os sistemas do idealismo alemão. Para os filósofos que o sucederam, a filosofia kantiana possuía a estranha situação de esconder o seu tema central por trás de sua forma final. ${ }^{352}$.

No caso de Hegel, ele não apenas reconhece a ambigüidade interna do pensamento kantiano, mas pretende também localizar as decisões previamente tomadas pelo seu discurso que impedem o reconhecimento da perspectiva especulativa contida em sua filosofia. Essa dupla dimensão de sua exegese está presente em toda leitura que Hegel faz de Kant, desde os escritos do período de Jena até suas últimas obras. Sua leitura implica, como pretendemos haver mostrado em nosso trabalho, em uma transformação do próprio discurso hegeliano, que a partir dela pôde chegar a constituir a perspectiva especulativa. Partindo de um discurso que compartilhava dos mesmos pressupostos do pensamento finito, o confronto com a dinâmica própria da vida e sua recusa em ser apreendida por meio de um instrumental conceitual abstrato, exigiu a reformulação de sua própria linguagem ${ }^{353}$. Procuramos mostrar como essa transformação, a construção de

\footnotetext{
${ }^{351}$ Hegel, Vorlesung über die Ästhetik I, Band.. XIII, p. 84.

352 Cf. Kroner, R. Von Kant bis Hegel, I, p. 227: "O tema fundamental de toda filosofia transcendental é a síntese em geral. (...) Com efeito, em Kant freqüentemente esse problema original do pensamento se esconde atrás do desmembramento analítico".

353 "Em suas primeiras aulas em Jena, ao longo dos anos 1801-1802, Hegel percorreu os passos naturais para um outro discurso (...) Nesse passo, temos novamente dois discursos: a análise crítica dos conceitos finitos e os usos dos mesmos termos em um discurso distinto que os articula em uma filosofia metodologicamente construtiva". Henrich, Between Kant und Hegel, p. 312.
} 
uma nova gramática especulativa, se deu a partir de uma reinterpretação da própria atividade reflexiva do pensar.

A reinterpretação especulativa operada por Hegel não pretende ser, todavia, uma imposição estranha e forçada, como "um 'ponto de vista' que se oporia àquele do entendimento (num antagonismo que seria ainda uma figura do entendimento)" ${ }^{354}$, mas antes uma reconfiguração do seu discurso que o reoriente em direção a um dizer mais adequado para pensar os problemas que a filosofia de Kant soube indiretamente colocar, sem saber, porém, como resolver. É nesse sentido que se pode escrever que "a exigência de ir além de Kant é, de acordo com a compreensão de Hegel, um imanente pensar a diante, e pensar até o fim o criticismo kantiano" 355 . Buscamos ao longo de nosso texto explicitar as razões pelas quais a leitura feita por Hegel não deve ser pensada como uma "crítica exterior e abstrata" - tarefa estranha à compreensão que Hegel possui da filosofia -, mas como uma perspectiva que visa indicar o "auto-desvio" da razão ou a "inversão da verdade contra um saber melhor" 356 .

"Reinterpretação" parece-nos o termo mais apropriado para a transposição de determinadas categorias para o interior de uma outra linguagem que lhe forneça um novo sentido. Nosso foco foi o de indicá-la tal como se realiza no conceito de reflexão. Através de um aprofundamento da atividade central da crítica, como que instigado pela própria filosofia de Kant, Hegel pôde desenvolver uma nova forma de pensar a atividade reflexiva, para além dos pressupostos críticos em que Kant a desenvolve. Por meio de uma "reflexão sobre a reflexão", a perspectiva especulativa visa colocar em xeque uma tese capital da filosofia de Kant, qual seja, a incognoscibilidade do absoluto pelas categorias da reflexão. Se suas categorias não podem efetivamente nada afirmar acerca

\footnotetext{
${ }^{354}$ Lebrun, G. L'antinomie et son contenu, p. 535. Cf. também, A Paciência do Conceito, p.203.

${ }^{355}$ Burkhardt, Bernd, Hegels Kritik an Kants theoretischer Philosophie, p.224 O grifo é de nossa autoria.

${ }^{356}$ Idem, p. 124. "Ambas censuras de Hegel, tanto a dualismo quanto a da absoluta finitude não podem pois ser mal compreendidas no sentido de uma crítica abstrata e exterior, mas são - de acordo com a tese de Hegel da autocontradição entre desenvolvimento [Ausführung]e princípio [Prinzip] - para serem tomadas em sua estrutura reflexiva, ou seja, como um auto-desvio [Selbstverfehlung], como inversão da verdade contra um saber melhor, ou como Richard Kroner o chamou, como uma recusa da 'auto-reflexão em segunda potencia' [Selbstbesinnung in der zweiten Potenz]".
} 
do que é em si, acerca das coisas mesmas ${ }^{357}$, a causa disso não está mais associada à reflexividade que está em sua base, mas antes ao seu emprego como operação meramente negativa, conduzida pelo modo de pensar do entendimento. A interpretação que orienta tal emprego é o verdadeiro alvo da filosofia especulativa. E se Hegel reconhece que o sistema kantiano "permaneceu vítima da reflexão" ${ }^{358}$, é fundamentalmente porque ele não pôde pôr em questão a decisão previamente tomada acerca da finitude do pensamento.

O que caracteriza a perspectiva especulativa, que se instaura a partir do aprofundamento da reflexão kantiana, é que Hegel não segue o caminho daqueles que, pressentindo a potência do pensamento kantiano, buscaram superar as oposições reflexivas através de uma intuição imediata do absoluto. Sua intenção fora antes a de "ultrapassar a reflexão com a reflexão" ${ }^{359}$, não aquela que permanece presa ao pensar finito, mas aquela que é, desde o início, especulativamente compreendida.

O aprofundamento da reflexão conduz, então, ao reconhecimento de duas modalidades distintas de interpretar sua atuação, cujos nomes são Razão e Entendimento. Estas deixam de ser consideradas como faculdades distintas do espírito, para ser agora concebidas como duas formas distintas de compreensão das diversas dimensões da vida.

"Em essência, Hegel chega agora a distinguir dois essenciais sistemas de filosofia: o systema reflectionis (sistema da reflexão) e o systema rationis (sistema da razão). O sistema da reflexão critica o entendimento, os meios finitos do raciocinar. O sistema da razão desenvolve o aparato conceitual que é adequado para descrever fenômenos como a vida e a unificação do amor na dimensão moral" 360 .

Como pretendemos haver mostrar nesse trabalho há uma transfiguração possível de um sistema para o outro, não na forma de uma tranqüila continuidade, mas por meio de um deslocamento de discurso. "As categorias da finitude não são apenas estruturas inconsistentes ou princípios de um discurso inadequado. Elas são somente os meios

\footnotetext{
${ }^{357}$ Cf. Hegel, VGPh, HW XX, p. 333.

${ }^{358}$ Hyppolite, J. La Critique Hegelianne de la Reflexion Kantienne, p. 88.

${ }^{359}$ Hyppolite, J. La Critique Hegelianne de la Reflexion Kantienne, p. 88.

${ }^{360}$ Henrich, Between Kant und Hegel, p. 312.
} 
preliminares e insuficientes de uma real compreensão das categorias da razão" ${ }^{361}$. Se a leitura que Hegel faz de Kant tem desde o início um tom ambivalente, seu desenvolvimento não é a busca de uma univocidade abstrata. Reconhecer a tensão de um sistema filosófico é, ao contrário, fazer um elogio à ambigüidade do pensamento.

${ }^{361}$ Henrich, Between Kant und Hegel, p. 313. 


\section{REFERÊNCIAS BIBLIOGRÁFICAS}

\section{Fontes primárias:}

FICHTE, J.G. Grundlage der gesammten Wissenschaftslehre. In: Fichte; Gesamtausgabe der Bayerischen Akademie der Wissenschaften, I,2. Lauth, R.; Fuchs, E;. Gliwitzky, H. (Org), Fromann-Holzboog, Stuttgart, 1962.

., Versuch einer neuen Darstellung der Wissenschaftslehre. In: Fichte; Gesamtausgabe der Bayerischen Akademie der Wissenschaften, I,4. Lauth, R.; Fuchs, E;. Gliwitzky, H. (Org), Fromann-Holzboog, Stuttgart, 1962.

HEGEL, G.W.F. Werke in zwanzig Bänden, auf der Grundlage der Werke von 18321845; neu edierte Ausgabe; Redaktion Eva Moldenhauer \& Karl Markus Michel. Suhrkamp. Frankfurt am Main, 1986.

., Georg Wilhelm Friedrich Hegel: Gesammelte Werke. In Verbindung mit der Deutschen Forschungsgemeinschaft. Hrsg. von der Rheinisch-Westfälischen Akademie der Wissenschaften und dem Hegel-Archiv der Ruhr-Universität Bochum, gedrückt mit Unterstützung der deutschen Forschungsgemeinschaft. F. Meiner Verlag, Hamburg, 1968ff.

., Escritos de juventud [1794-1801]. Edición, introducción y notas de Jose M. Ripalda. Fondo de Cultura Economica, México, 1978,1984.

., Diferença entre os Sistemas Filosóficos de Fichte e de Schelling;

Tradução, introdução e notas de Carlos A. V. Morujão; Imprensa Nacional - Casa da Moeda, Lisboa, 2003.

., Enciclopédia das Ciências Filosóficas em Compêndio; Tradução de Paulo

Meneses e José Machado. Edições Loyola, São Paulo, 1995.

., Esboços sobre Religião e Amor (1797/98), in Revista Eletrônica de

Estudos Hegelianos, Ano 2 N. $^{\circ} 03$ (Dezembro, 2005), disponível em: http://www.hegelbrasil.org/rev03trad.htm (comentário e trad.: Erick C. De Lima).

., Fé e Saber; Tradução de Oliver Tolle, Hedra, São Paulo, 2007. 
., Fragmento de um Sistema (1800). Tradução e comentário de Erick C. De Lima); In: Cadernos de Filosofia Alemã, FFLCH-USP, nº10, São Paulo, 2007. ., O Mais Antigo Programa de Sistema do Idealismo alemão (1796); Comentário e tradução de Joãosinho Beckenkamp; In: BECKENKAMP, J., Entre Kant e Hegel, EDIPUCRS, Porto Alegre, 2004.

., Como o Senso Comum Compreende a Filosofia. Apresentação de JeanMarie Lardic, seguido de um ensaio sobre a contingência em Hegel. Tradução de Eloisa Araujo Ribeiro. Ed. Paz e Terra, Rio de Janeiro, 1994. ., Briefe von und an Hegel. Felix Meiner Verlag: Philosophische Bibliothek V. 238, Hamburg, 1981.

KANT, I. Kants gesammelte Schriften: herausgegeben von der Deutschen Akademie der Wissenschaften, anteriormente Königlichen Preussischen Akademie der Wissenschaften, 29 vols, Walter de Gruyter, Berlin, $1902 \mathrm{ff}$.

., Crítica da Razão Pura. Trad. de Manuela Pinto dos Santos e Alexandre F. Morujão. Ed. Calouste Gulbenkian, Lisboa, 1997.

., Crítica da Razão Prática. Trad. de Arthut Mourão. Ed. 70, Lisboa, 1993.

., Crítica da Faculdade do Juízo. Trad. de Valério Rohden e Antônio Marques. Editora Forense Universitária; Rio de Janeiro, 2ª ed, 1995.

., Manual dos cursos de Lógica. Tradução e apresentação de Fausto Castilho. Edufu/Editora Unicamp, Campinas, 2002.

., Resposta à Pergunta: Que é o Esclarecimento? Trad. Floriano de Souza Fernandes, In: Textos Seletos, $2^{\mathrm{a}}$ Edição, Editora Vozes, Petrópolis, RJ, 1985. ., Antropologia de um Ponto de Vista Pragmático. Trad. Clélia Aparecida Martins, Ed. Iluminuras, São Paulo, 2006. ., Duas Introduções à Crítica do Juízo. Terra R. (Org). Iluminuras, São Paulo, 1995.

SCHELLING, F. W. J. Ideen zu einer Philosophie der Natur. In: Schellings Werke, Bd. 2 C.H. Beck, München, 1979. ., Darstellung meines Systems der Philosophie. In: Schellings Werke, Bd. 3. C.H. Beck, München, 1958. 
., Über die Konstruktion in der Philosophie.. In: Schellings Werke, Bd. 3. C.H. Beck, München, 1958.

., Cartas filosóficas sobre o dogmatismo e o criticismo. Tradução de Rubens

Rodrigues Torres Filho, São Paulo: Abril Cultural, 1973.

\section{Fontes secundárias:}

BAUM, M., Die Entstehung der Hegelschen Dialektik. Bouvier, Bonn, 1986.

BECKENKAMP, J., O Jovem Hegel, Formação de um Sistema Pós-kantiano. Edições Loyola, São Paulo, 2009.

., Entre Kant e Hegel. EDIPUCRS, Porto Alegre, 2004.

BONSIEPEN, W., Der Begriff der Negativität in den Jaener Schriften Hegel. In:HegelStudien, Beiheft 16, Bouvier, Bonn, 1972.

BOURGEOIS, B., A Enciclopédia Filosófica de Hegel. [1986] In: Hegel, Enciclopédia das Ciências Filosóficas, em Compêndio. V I. Edições Loyola, São Paulo, 2005. ., Le Droit Naturel de Hegel (1802-1803) Commentaire. Vrin, Paris, 1986. ., Hegel à Francfort ou Judaïsme- Christianisme-Hegelianisme. Vrin, Paris, 1970. ., Savoir et Foi: la réconciliation hégelienne contre la conciliation kantienne. In: Revue Internationale de Philosophie. Vol. 53, n² 210, 4/1999.

BURKHARDT, B. Hegels Kritik na Kants theoretischer Philosophie; dargestellt und beurteilt an den Themen der metaphysica specialis. Profil, München, 1989.

COHEN, H. Commentaire de la Critique de la raison pure. Edition du Cerf, Paris, 2000, DILTHEY, W. Die jungendgeschichte Hegels und andere Abhandlungen zur Geschichte der deutschen Idealismus. In: Dilthey: Gesammelte Schriften, Bd. IV, Stuttgart, 1959.

DOTTORI, R. Die Reflexion des Wiklichen.Mohr Siebeck, Tübingen, 2006.

DÜSING, K. Spekulation und Reflexion. Zur Zusammenarbeit Schellings und Hegels in Jena. In:Hegel-Studien, Band 5, Bouvier, Bonn, 1969. ., Das Problem der Subjektivität in Hegels Logik. In: Hegel-Studien, Beiheft 15, Bouvier Verlag, Bonn, 1976. 
., Die Rezeption der kantischen Postulatenlehre in den frühen philosophischen Entwürfen Schellings und Hegels. In: Bubner, R. Das älteste Systemprogramm. Hegel-Studien, Beiheft 9, Bouvier, Bonn, 1973. ., Düsing, K. Hegel in Jena. Die Entwicklung des Systems und die Zusammenarbeit mit Schelling. (Hegel-Studien, Beiheft 20), Bonn, 1980.

FERREIRA, M.J.C. Hegel e a justificação da filosofia. Estudos Gerais - Série Universitária. Imprensa Nacional/Casa da Moeda, Lisboa, 1992.

FUJITA, M. Philosophie und Religion beim jungen Hegel. In:Hegel-Studien, Beiheft 26, Bonn, 1985.

GÖBEL, W. Reflektierende und absolute Vernunft. Die Aufgabe der Philosophie und ihre Lösung in Kants Vernunftkritiken und Hegels Differenzschrift. Bouvier, Bonn, 1984.

GÖRLAND, I. Die Kantkritik des jungen Hegels. Vittorio Klosterman Verlag, Frankfurt am Main, 1999.

GRANDJEAN, A. Critique et Réflexion. Essai sur le Discours Kantien. Vrin, Paris, 2009.

GUEROULT, M. Le Jugement de Hegel sur l'Antithétique de la Raison pure. In: Revue de Métaphysique et de Morale, 1931, pp. 413-439.

HABERMAS, J. O Discurso Filosófico da Modernidade. Ed. Martins Fontes, São Paulo, 2002.

HARTMANN, N. Die Philosophie des deutschen Idealismus. Gruyter, Berlin, 1974.

HARRIS, H. Le développement de Hegel, Tome I et II. Édition L'Age d'Homme, 1981/1988.

HAERING, T.L. Hegel sein Wollen und sein Werk. Band I, B.G.Teubner Verlag, Leipzig/Berlin, 1929.

HAYM, R. Hegel und seine Zeit. Vorlesung über Entstehung und Entwicklung, Wesen und Werth der hegel'schen Philosophie. Rudolph Gaertner Verlag, Berlin, 1857.

HEIDEGGER, M. Seminare. Gesamtausgabe, Bd. 15. Klostermann, Frankfurt am Main, 2005.

., Der deutsche Idealismus (Fichte, Schelling und Hegel), Gesamtausgabe, Bd. 28.. Klostermann, Frankfurt am Main, 1997. 
HENRICH, D. Between Kant and Hegel. Lectures on German Idealism. Edited by David S. Pacini. Harvard University Press, London, 2003. ., Hegel im Kontext. Suhrkamp, Frankfurt am Main/Berlin, 2010.

HEßBRÜGGEN-WALTER, S. Topik, Reflexion und Vorurteilskritik: Kants ,Amphibolie der Reflexionsbegriffe' im Kontext. Archiv für Gescichte der Philosophie. Band 86, pp. 146-175, Walter de Gruyter, Berlin, 2004.

HORSTMANN, R.P. Die Grenzen der Vernunft. Klostermann, 3.Auflage, 2004.

., Kant und der "Standpunkt der Sittlichkeit". Zur Destruktion der Kantischen Philosophie durch Hegel. Revue Internationale de Philosophie. Vol. 53, $\mathrm{n}^{\circ}$ $210,4 / 1999$.

., Den Verstand zur Vernunft zu bringen. Hegels Auseinandersetzung mit Kant in der Differenz-schrifft. In: Das Interesse des Denkens Hegels aus heutiger Sicht. W. Welsch \& K. Vieweg Hrsg. Wilhelm Fink Verlag, München, 2003.

HYPPOLITE, J. La critique hegelienne de la reflexion kantienne. In: Kant-Studien, Band 45, Heft 1-4, pp. 83-95, Köln, 1953/1954.

JAESCHKE, W. Hegel Handbuch. J.B Metzler Verlag, Stuttgart, 2003.

KRONER, R. Von Kant bis Hegel. Mohr Siebeck Verlag, 4.Auflage, 2006.

LA ROCCA, C. Vorläufige Urteile und Urteilskraft. Zur heuristischen Logik des Erkenntnisprozesses. Kant und die Berliner Aufklärung. Akt des IX. Internationalen Kant-Kongresses. Band II: Sektion I-V, pp. 351-361, Walter de Gruyter, Berlin, 2001.

LEBRUN, G. L'antinomie et son contenu. In: Revue Internatinale de Philosophie. Vol. 53, $\mathrm{n}^{\circ} 210$, PUF, 4/1999, pp. 505-536.

., A antinomia e seu conteúdo. In: A Filosofia e sua História. Trad. Márcio Suzuki. Ed. CosacNaify, São Paulo, 2006, pp. 567-597. ., A Paciência do Conceito. Ensaio sobre o discurso Hegeliano. UNESP, 2006. ., Kant et la fin de la métaphysique. Paris: Librairie Armand Colin, 1970.

LIEDTKE, M. Der Begriff der Reflexion bei Kant. Archiv für Gescichte der Philosophie. Band 48, Heft 2, pp. 207-216, Walter de Gruyter, Berlin, 1966.

LIMA, E.C. Crítica da moral deontológica no jovem Hegel; In: Educação e Filosofia, v. 22, n. 43, jan/jun, Uberlândia, 2008. 
LONGUENESSE, B. Kant and the Capacity to Judge. Princeton and Oxford: Princeton University Press, 1998.

MARCUSE, H. Hegels Ontologie und die Theorie der Geschichtlichkeit. In: Herbert Marcuse Schriften, Bd. 2, Suhrkamp Verlag, 1989.

., Razão e Revolução. Hegel e o advento da teoria social. Ed. Paz e Terra, São Paulo, 2004.

MARQUES, A. A Razão Judicativa. Edição: Imprensa Nacional-Casa da Moeda, Lisboa, 2004. ., Organismo e sistema em Kant. Ensaio sobre o Sistema Crítico Kantiano.

Editorial Presença, 1987.

PHILONENKO, A. Introduction à Foi et Savoir. In: Foi et Savoir. Traduction: A. Philonenko/ C. Lecouteux. Vrin, Paris, 1988.

PIPPIN, R. Hegels Idealism. The Satisfaction os Self-Consciousness. Cambridge University Press, 1989.

PÖGGELER, O. Hegel und die Anfänge der Nihilismus-Diskussion. In: Arendt, D. Der Nihilismus als Phänomen der Geistesgeschichte in der wissenschaftlichen Diskussion unseres Jahrhunderts. Wissenschaftliche Buchgesellschaft, Darmstadt, 1974.

PRIEST, S. (Ed.). Hegels critique of Kant. Clarendon, Oxford, 1987.

RENAULT, A. Kant aujourd'hui. Champs/Flammarion - Aubier, Paris, 1997.

REUTER, P. Kants Theorie der Reflexionsbegriffe. Eine Untersuchung zum Amphiboliekapitel der Kritik der reinen Vernunft. Königshausen \& Neumann, Würzburg, 1989.

ROHDEN, V. Interesse da Razão e Liberdade. Editora Ática, São Paulo, 1981.

SEDGWICK, S. (Ed.). The Reception of Kant's Critical Philosophy. Fichte, Schelling and Hegel. Cambridge University Press, Cambridge, 2000.

SIEP, L. Der Weg der Phänomenologie des Geistes. Suhrkamp Verlag, Frankfurt am Main, 1973.

SILVA, F.L. Subjetividade e Juízo. In: discurso - Revista do dep. de Filosofia da USP, (19), pp. 29-42, São Paulo, 1992.

STANGUENNEC, A. Hegel critique de Kant, PUF, Paris, 1985. 
TORRES FILHO, R.R. O espirito e a letra. A crítica da imaginação pura em Fichte, Editora Ática, 1975.

ZIMMERLI, W. Ch. Inwiefern wirkt Kritik systemkonstituierend?; In: Düsing, K. Hegel in Jena. Die Entwicklung des Systems und die Zusammenarbeit mit Schelling. (HegelStudien, Beiheft 20), Bonn, 1980.

VIGO, A. Reflexión y Juicio. Diánoia - Anuário de Filosofia, vol. LI, no. 57, México, 2006. 